\title{
MALIN SUNDSTRÖM
}

EXISTENTIELL ENSAMHET

HOS SKÖRA ÄLDRE PERSONER

Vårdpersonals och volontärers erfarenheter och behov av stöd
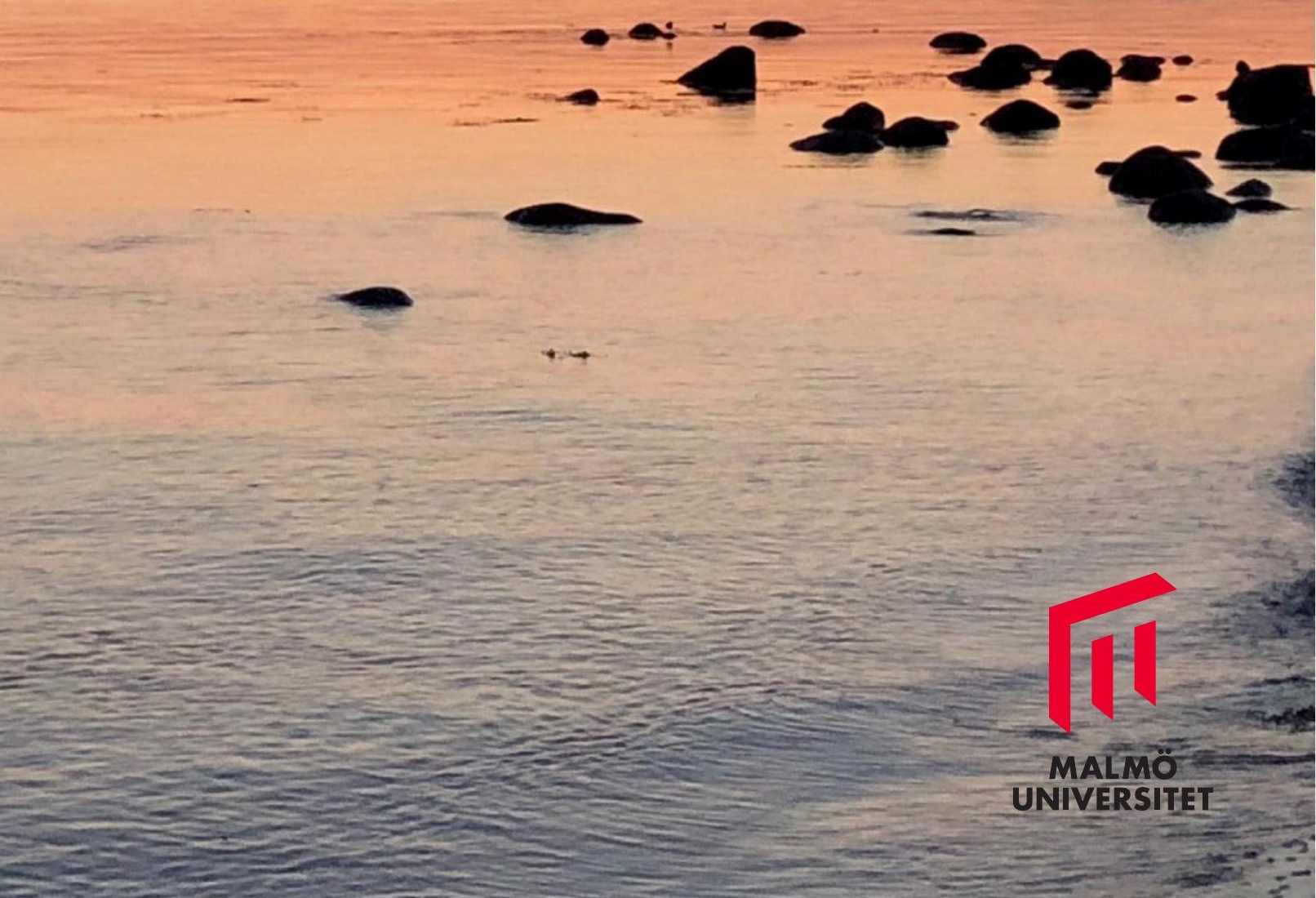

EXISTENTIELL ENSAMHET HOS SKÖRA ÄLDRE PERSONER:

VÅRDPERSONALS OCH VOLONTÄRERS ERFARENHETER

OCH BEHOV AV STÖD 
Malmö universitet, Fakulteten för hälsa och samhälle Institutionen för vårdvetenskap

Doktorsavhandling 2020:2

(C) Copyright Malin Sundström 2020

Foto: Malin Sundström

ISBN 978-9I-7877-066-3 (tryckt)

ISBN 978-9I-7877-065-6 (pdf)

ISSN I $653-5383$

DOI I 0.24834 isbn.9789I78770656

ISBN 978-9I-87973-47-5 Högskolan Kristianstad

Tryck: Holmbergs, Malmö 2020 


\section{MALIN SUNDSTRO̊M \\ EXISTENTIELL ENSAMHET \\ HOS SKÖRA ÄLDRE PERSONER}

Vårdpersonals och volontärers erfarenheter och behov av stöd

Malmö universitet, 2020

Fakulteten för hälsa och samhälle Högskolan Kristianstad Forskningsplattformen Hälsa i samverkan 
Publikationen finns även elektroniskt, se https://mau.diva-portal.org/ 
Till alla er som hjälpt mig fram till denna avhandling - ni är många.

"Två sanningar närmar sig varann. En kommer inifrån, en kommer utifrån och där de möts har man en chans att få se sig själv.”

Preludier II ur diktsviten Mörkerseende av Tomas Tranströmer (1970) 



\section{INNEHÅLL}

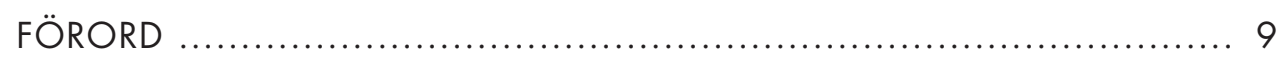

ABSTRACT [............................................................. 11

DEFINITIONER ....................................................... 13

ORGINALARTIKLAR ................................................ 14

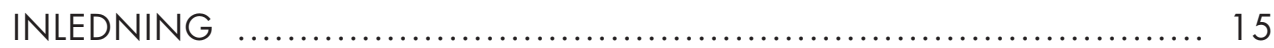

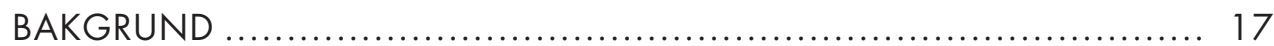

Ensamheter och existentiell ensamhet .............................................. 17

Åldrandet - en existentiell utmaning ................................................. 19

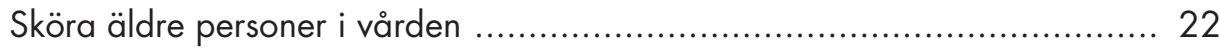

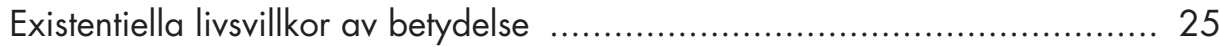

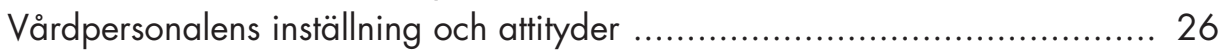

Vårdpersonalens utmaningar i olika vårdkontexter ............................... 27

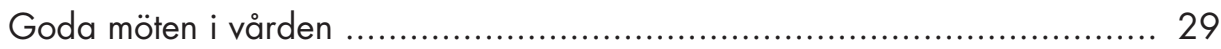

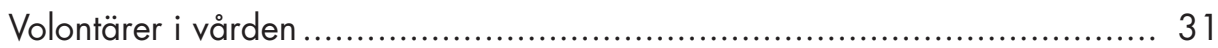

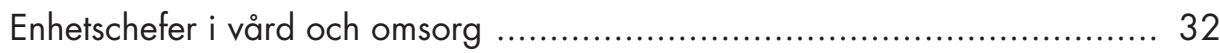

MOTIV FÖR AVHANDLINGEN ....................................... 35

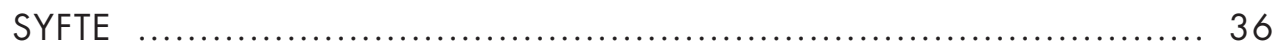

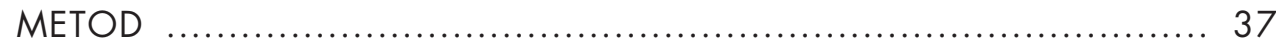

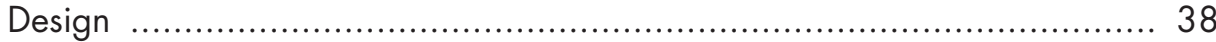

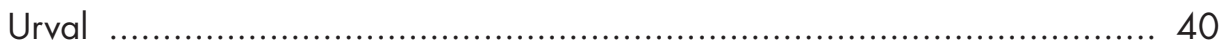

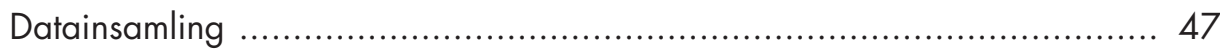

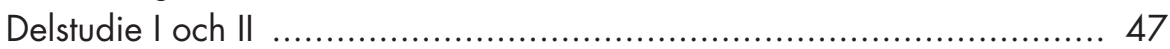

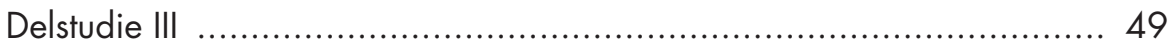

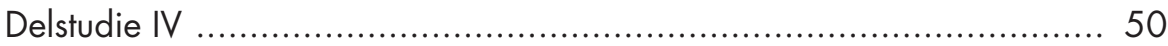

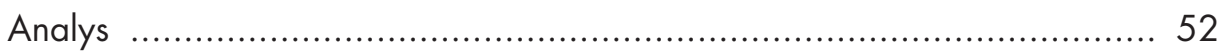

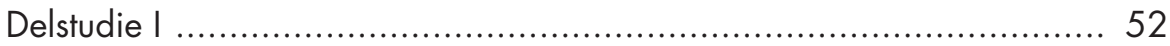

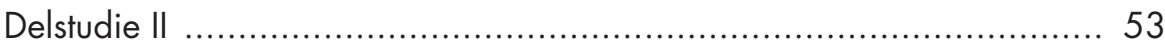

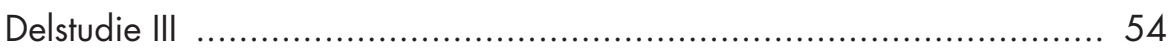

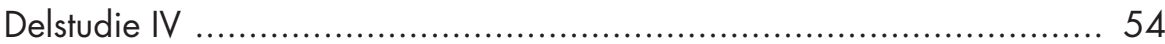


ETISKA ASPEKTER

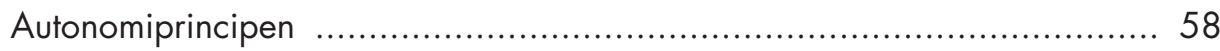

Principerna att inte skada och göra gott ......................................... 59

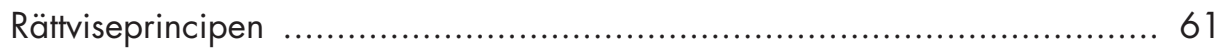

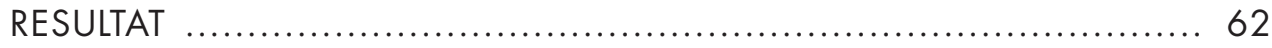

Vårdpersonalens erfarenheter av existentiell ensamhet ........................... 62

Betydelsefulla egenskaper för att tolka och förstå ............................ 62

Vårdpersonalens beskrivning av hinder i mötet ................................... 63

Vårdkontextens betydelse för existentiell ensamhet ................................. 65

Skillnader och likheter mellan olika vårdkontexter .............................. 67

Volontärers erfarenheter av att möta olika ensamheter ............................ 68

Att bli volontär - finna mening och lindra ensamhet .......................... 69

Att vara volontär - förutsättningar och utmaningar ........................... 70

Att vara lyhörd för behov av närhet och distans ............................... 70

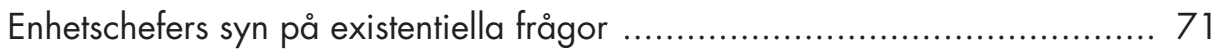

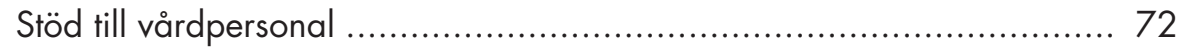

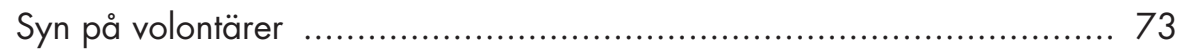

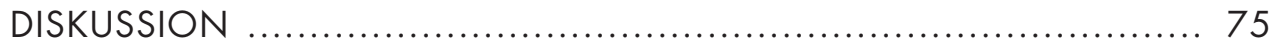

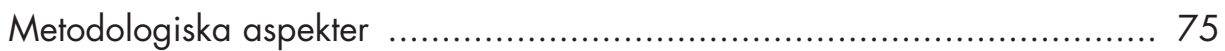

Trovärdighet studie I-III ....................................................... 76

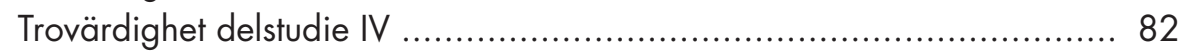

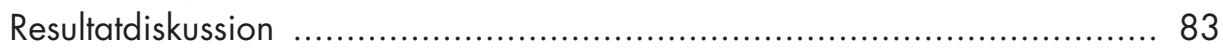

Relationens betydelse för att möta existentiell ensamhet ..................... 84

Vårdkontextens betydelse för att möta existentiell ensamhet .................. 87

Stöd till personal i att möta existentiell ensamhet ................................ 89

Handlingsutrymme och tillit i organisationen ................................... 91

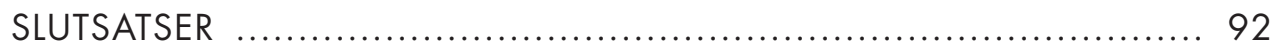

KLINISKA IMPLIKATIONER ......................................... 93

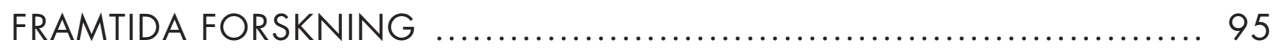

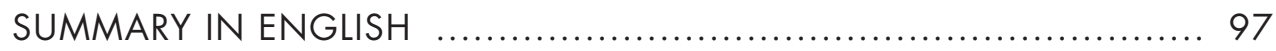

TACK ............................................................. 101

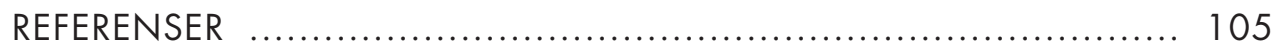

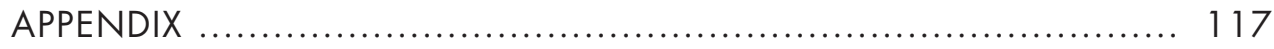

DELSTUDIE I-IV .................................................. 125 


\section{FÖRORD}

Jag har befunnit mig i vårdens värld i mer än 30 år. Det började med ett sommarjobb, i det som då kallades långvård, på en avdelning för personer med demenssjukdomar och psykiatriska diagnoser. Det var i en tid när de som bodde på avdelningen bar sjukhusets kläder och hade sina rum möblerade med sjukhusets säng och sängbord. De flesta delade rum med en eller flera andra personer. Trots vissa omständigheter som är svåra att tänka sig i dag, trivdes jag att arbeta med de äldre. På avdelningen där jag arbetade fanns en omsorg och omtanke om både de äldre och om varandra. Efter tre somrar och avslutat gymnasium valde jag att läsa till undersköterska med målet att bli sjuksköterska. Så blev det och jag avslutade sjuksköterskeutbildningen 1992. Sedan dess har vården genomgått många förändringar som har inneburit förbättringar för de äldre på många sätt, med mer valfrihet och delaktighet. Samtidigt finns det brister och mycket som återstår att förbättra. Inte minst i en samtid när tiden blivit alltmer reglerad och så kallade insatser hos de äldre ska kontrolleras och tidsbestämmas i syfte att kvalitetssäkra vården. Vad händer då med det mellanmänskliga?

Frågor som handlar om livet och hur det är att vara människa intresserar mig, liksom möten mellan människor. Jag hade tänkt att om det skulle öppna sig en möjlighet för mig att gå en forskarutbildning så skulle min forskning på något sätt handla om äldre personer. Jag fick en möjlighet och det blev det ett avhandlingsarbete som handlar om sköra äldre personer och existentiell ensamhet, och möten mellan människor. I början av projektet läste jag en bok som bygger på en brevväxling om ensamhet. Ett citat om ensamhet från den boken får illustrera hur mångfacetterad ensamhet kan vara.

Att förstå ensamhet är per definition att förstå att man inte förstår. För ensamheten är inte bara ensamhet. Att närma sig ensamhet är att närma 
sig existensens innersta. Att tala om ensamhet innebär att tala om vår tillräcklighet och otillräcklighet och viljan att duga, om att finnas till och rent av bli till - med andra, om skuld och ångest, men också vila, mellanrum och pauser, och glädje, energi, kärlek.

(Dahlberg, Stolt \& Dahlberg, 2015, s. 108)

När Dalai Lama besökte Malmö på inbjudan av Individuell Människohjälp i september 2018 bjöd Malmö universitet in till en träff. Varje fakultet fick ett antal platser som fördelades bland de studenter som visade intresse och vi ombads även att skicka in en fråga till Dalai Lama. Jag hade turen att få en plats och min fråga kom också med. Den lästes upp av en representant från studentkåren och medan den lästes fick jag stå upp. Jag minns att Dalai Lama tittade på mig och log under tiden. Min fråga löd: Loneliness is an increasing problem for many people around the world. How can we fight this, since it is something that affects people and their life and health in many ways? När Dalai Lama hade hört frågan och stämt av med sin närmaste man att han uppfattat frågan rätt svarade han mig:

\begin{abstract}
Det beror helt och hållet på ditt eget sätt att tänka. Om man hela tiden tänker jag, jag, jag, så leder det till ett ensamhetstänkande. Om man i stället tänker på alla sju miljarder människor som finns på jorden kan det vara ett kraftfullt sätt att motverka ensamhet. Som buddhistmunk är det en del av min dagliga praktik att tänka att vi är en del av ett större sammanhang. Vi vill alla ha lycka och vi har samma rätt till lycka. Det förenar oss. Det gör att man inte känner sig ensam. (fritt översatt)
\end{abstract}

Jag har tänkt mycket på det svaret. Det stämmer förstås på ett sätt och det blev också tydligt för mig hur kulturell och kontextbunden ensamhet kan vara. För Dalai Lama var övertygelsen stark och kanske har han aldrig känt sig ensam. Ensamhet är dock en subjektiv känsla. För de som känner sig ensamma, oavsett orsak, är det viktigt att bli bemött med respekt och utan värdering. Det paradoxala med existentiell ensamhet är dock att känslan av att vara separerad från andra på samma gång kan skapa en känsla av samhörighet eftersom många människor har upplevt det på ett eller annat sätt. Så, med Dalai Lamas ord klingande i mina öron, är vi ensamma på ett sätt, men på ett annat sätt är vi inte det på grund av den samhörighet som finns i att vara människa. 


\section{ABSTRACT}

The overall aim of the thesis was to explore healthcare professionals' and volunteers' experiences of encountering older persons' existential loneliness, the significance of the care context, and first-line managers' view of support. Three of the studies were qualitative with a descriptive design (studies I-III) and the fourth was quantitative with a cross-sectional design (Study IV). The data collection for studies I and II was based on focus group interviews with healthcare professionals (i.e., nurse assistant, registered nurse, physician, occupational therapist, physiotherapist, social counsellor, and social worker) in home care, residential care, hospital care, palliative care, primary care, and pre-hospital care. The data collection for Study III was based on focus group interviews and individual interviews with volunteers from various organisations. Study IV was based on a questionnaire sent to first-line managers in municipal care, examining their views of support for staff and volunteers encountering existential issues among older persons.

The findings of Study I indicated that, during the everyday care of older people, healthcare professionals experienced existential loneliness in various ways and situations related to ageing, illness, and end of life. The professionals' stories about encountering older persons' existential loneliness revealed that they often felt insecure about how to talk about existential issues. They also felt inadequate and frustrated when encountering barriers such as the older person's bodily limitations, demands and needs (perceived as insatiable), personal privacy, or fear and difficulty in encountering existential issues. Study II was a multiple case study of the care contexts of home care, residential care, hospital care, and palliative care. The findings indicated that the care context matters regarding professionals' views and interpretations of the origin of existential loneliness. In home care and residential care, these views and interpretations concerned life, the present, and the past. In hospital and palliative care, existential loneliness mainly concerned the older person's forthcoming death. Professionals considered creating relationships an important part of their role in all care contexts, although the meanings, purposes, and conditions of these relationships differed (Study II). Study III showed that being a volunteer meant being a fellow human being, alleviating others' and one's own loneliness. Becoming a volunteer was 
a way of finding meaning, and volunteering made the volunteers feel rewarded and simultaneously emotionally challenged. Encountering loneliness, including existential loneliness, required sensitivity to others' needs for both closeness and distance. The findings of Study IV, based on a questionnaire, indicated that $88 \%$ of the first-line managers found that older persons sometimes or often expressed existential loneliness. They also reported that staff insecurity was the major obstacle to talking about existential issues with the older persons. Support was provided in the form of structured reflection, but provision of systematic supervision was reported by only $6 \%$ of first-line managers. The managers reported that most support was provided by themselves or by registered nurses. Almost half of the managers (44\%) reported that, at their units, volunteers were engaged in activities such as everyday conversations and/or music/entertainment. In addition, they also reported a desire for volunteers to be more involved in both everyday and existential conversations. In conclusion, one of the most important findings of this thesis was the insecurity of the professionals, manifested in a fear of discussing existential issues. This was revealed in the interviews with the professionals and confirmed by the first-line managers. According to both professionals and volunteers, the relationship with the older person was important when encountering existential issues. The thesis demonstrates the importance of helping professionals focus on existential issues about life and death and of the potential of volunteers as an important complement in the care of older people. 


\section{DEFINITIONER}

Existentiella frågor är frågor som handlar om att vara människa, att känna mening, hopp och tillit, om livet och döden. Frågor som inte har några självklara svar.

Existentiella samtal är samtal om existentiella frågor.

Existentiell ensamhet definieras som en djupare känsla av ensamhet och en ofrånkomlig del av livet. Den existentiella ensamheten kan uppstå i olika situationer, trots att personen har nära relationer och omges av andra människor.

LONE-studien är det projekt som avhandlingen är en del av. LON står för loneliness (ensamhet) och $E$ står för existential (existentiell). LONE-studien presenteras närmare i metodavsnittet.

Sköra äldre personer definieras i LONE-studien och i denna avhandling som personer som är 75 år och äldre och som är i behov av varaktig vård och omsorg.

Skörhet hos äldre personer är i denna avhandling förknippad med fysisk skörhet som hänger samman med åldrandets sjukdomar, och utesluter inte att personen har andra styrkor och inre kraft.

Volontär är en person som erbjuder sina tjänster frivilligt utan att kräva någon betalning, oftast organiserat genom en frivilligorganisation. Volontärerna kallas ibland för frivilliga, ideella eller aktiva medlemmar.

Vårdkontext är den miljö där vården sker, men är också en plats. I denna avhandling ingår vårdkontexterna hemvård/hemtjänst, särskilt boende, sjukhus, palliativ vård, primärvård och ambulanssjukvård.

Vårdpersonal är i den här avhandlingen personer som i sin profession, oavsett vårdkontext, profession, funktion eller uppgift, vårdar äldre personer. Kallas också personal eller formella vårdare $\mathrm{i}$ avhandlingen. 


\section{ORGINALARTIKLAR}

Sundström, M., Edberg, A-K., Rämgård, M. \& Blomqvist, K. (2018). Encountering existential loneliness among older people: Perspectives of health care professionals. International Journal on Qualitative Studies on Health and Wellbeing, 13(1): 1474673.

II Sundström, M., Blomqvist, K., Edberg, A-K. \& Rämgård, M. (2019). The context of care matters: Older people's existential loneliness from the perspective of healthcare professionals. A multiple case study. International Journal of Older People Nursing, 14(3): e1223414.

III Sundström, M., Blomqvist, K. \& Edberg, A-K. Being a volunteer encountering older people's loneliness and existential loneliness: Alleviating loneliness for others and oneself. Inskickad för publicering.

IV

Sundström, M., Blomqvist, K., Rämgård, M. \& Edberg, A-K. Encountering older persons' existential issues: First-line managers' views on staff's and volunteers' possibilities, obstacles and need for support. Manuskript.

Tillstånd finns för att publicera artiklarna eller manus i avhandlingen i sin helhet. I avhandlingen refereras delstudierna till sina romerska siffror. 


\section{INLEDNING}

Människor åldras på olika sätt. För en del är tiden när man blivit äldre en period med tillgång till tid att umgås med familj och vänner, att ha tid att samla ihop sitt liv och reflektera över hur saker och ting blev som de blev. Åldrandet kan också innebära utmaningar i form av förluster och ovisshet inför framtiden, då den sista tiden i livet är en tid när sjukdomar och döden gör sig allt mer påminda. Människor har fysiska, psykologiska, sociala och existentiella behov och dessa finns med under hela livet. Åldrandet innebär för många att bli begränsad av kroppen och så småningom i sin rörelsefrihet. Det i sin tur kan väcka existentiella tankar om livet och tillvaron. Om existentiella tankar och funderingar inte bemöts eller bejakas kan oro och existentiell ensamhet, det vill säga en känsla av att vara "ensam i världen" uppstå, trots att det kan finnas människor runt omkring (Sand \& Strang, 2006). Samtidigt ställer det krav på att vårdpersonal i olika professioner har kunskap och beredskap att samtala om dessa frågor i mötet med äldre. Dock visar senare forskning att det kan vara en stor utmaning för vårdpersonal att skapa utrymme för existentiella frågor i vardagen bland alla uppgifter som måste genomföras (Beck, 2013; Norell Pejner, 2013; Sundler, Eide, van Dulmen \& Holmström, 2016). I en begreppsanalys av Ettema, Derksen och van Leeuwen (2010) drar författarna slutsatsen att begreppet existentiell ensamhet, en djupare känsla av ensamhet, är otydligt. Det innebär sannolikt också att begreppet inte bara är otydligt, utan kanske även osynligt eller ordlöst för vårdpersonal.

Det verkar också finnas ett samband mellan den plats man vårdas på och hur man upplever sin situation, vilket skulle innebära att vårdkontexten har betydelse för den äldres upplevelse av existentiell ensamhet. Vårdens fragmentering och organisering med medicinsk specialisering och ett uppgiftscentrerat vårdarbete kan exempelvis innebära ett hinder för att det existentiella samtalet ska kunna äga rum. Även inom vårdenheter som vårdar personer med cancersjukdomar och inom palliativ vård, som har en vårdfilosofi eller en värdegrund som bejakar såväl livet som den goda döden (WHO, u.å.; Regionala Cancercentrum i Samverkan, 2016) finns ett behov av utbildning och utrymme för reflektion kring dessa frågor (Strang, Henoch, Danielson, Browall \& Melin-Johansson, 2014; Udo, 2012). En annan grupp som möter äldre personer i olika sammanhang är volontärer. Det finns forskning om volontärer och 
volontärorganisationer i Sverige och Norden, liksom forskning om volontärer i övriga världen. Det är mer sparsamt när det gäller forskning om volontärers egna erfarenheter av att möta äldre personer i olika vårdsammanhang, och om volontärers erfarenhet av existentiell ensamhet hos äldre personer.

Trots att det finns kunskap om vikten av det existentiella samtalet inom vården, saknas kunskap om vårdpersonalens erfarenheter av att möta äldre personers existentiella ensamhet. Det saknas också kunskap om volontärers erfarenhet och om de kan bidra till äldre personers välbefinnande. Enhetschefer inom vård och omsorg, med ansvar för verksamheten, besitter kunskap om både de äldres tillvaro och vårdpersonalens arbetssituation. Kunskap om deras syn på vårdpersonals och volontärers möjligheter och hinder för att möta äldre personers existentiella behov, kan bidra med ytterligare ett perspektiv. Sådan samlad kunskap kan i sin tur utgöra grunden för utvecklingen av interventioner exempelvis inom vård och omsorg. 


\section{BAKGRUND}

\section{Ensamheter och existentiell ensamhet}

Det finns olika slags ensamheter och de flesta människor upplever ensamhet till och från under livet. Den sociala ensamheten brukar relateras till begränsade sociala nätverk och få sociala kontakter trots att personen skulle vilja ha kontakt med andra. Den emotionella ensamheten handlar i stället om en avsaknad av nära och djupa band till någon eller några personer (Mansfield m.fl., 2019). Ensamhet är en subjektiv erfarenhet och en person kan vara ensam utan att känna sig ensam, liksom en person kan känna sig ensam i en samling med andra människor (Peplau \& Perlman, 1982). Det finns flera synonymer till ordet ensamhet såsom avskildhet, isolering, enslighet, avsaknad av sällskap, övergivenhet och tomhet. Motsatsorden som anges är gemenskap, sällskap och samhörighet (Synonymer, 2020). De flesta av synonymerna till ensamhet har en negativ innebörd. Avskildhet är det ord som har en positiv andemening och som i sin tur har tillbakadragenhet och stillhet som synonymer. Det antyder att det finns ett inslag av eget val och en positiv effekt av ensamheten. Det engelska språket har fler uttryck och förutom loneliness, även aloneness och solitude där loneliness står för den ofrivilliga ensamheten som är förenad med negativa termer och de andra två för den självvalda ensamheten. I det svenska språket kan i stället den självvalda ensamheten användas som motsvarighet till de två senare engelska orden. Ett annat uttryck skulle kunna vara självsamhet (Jonkman, 2013). Det kan hos andra handla om en självständig ensamhet som byggts upp under hela livet och är en del av personligheten. En annan ensamhet som innebär en känsla av främlingskap eller alienation kan uppstå inför andra personer i ens närhet, en känsla av att vara annorlunda. Det kan också handla om ett främlingskap mot samtiden när den äldre inte känner igen sig i samhället längre och som att vara ensam kvar ur sin egen generation eller inte längre känna gemenskap med sin familj (Broström, 2014; CohenMansfield, Hazan, Lerman \& Shalom, 2015). En flytt sent i livet och att inte kunna knyta an till plats och nya relationer kan också skapa en känsla av ensamhet, att inte känna sig hemma, eller känna sig rotad. Platsens betydelse har med identitet, förankring och meningsskapande att göra (Altman \& Low, 1992) och känslan av att vara hemma får därför särskild betydelse för sköra äldre personer (Rowles \& Bernard, 
2013). Enligt Taube (2015) kan ensamhet hos äldre förändras över tid och i intensitet och kan även finnas parallellt med en positiv dimension av ensamhet, i form av frihet. Ensamhet är följaktligen inget enhetligt fenomen och kan förändras i relation till plats, situation, relation och över tid.

Den existentiella ensamheten, den djupare formen av ensamhet som flera filosofer har beskrivit utifrån existentiella tankegångar är förenad med den mänskliga tillvaron (Yalom, 1980; Tillich, 1963). Vi är alltid ensamma fast vi är inte alltid medvetna om det enligt Mijuskovic (2012) och ensamhet och död är något alla människor måste konfrontera. Tillich (1963) har liknande tankegångar och menar att skuld och död är olika former av ensamhet som ingen människa kommer undan. Det innebär att existentiella tankar förekommer hos människor under hela livet och inte enbart vid livets slut. Tillich (1963) gör skillnad på den smärtsamma ensamheten och den självvalda, där den senare kan vara en ynnest. Applebaum (1978) menar att insikten om att vara existentiellt ensam ofta framträder när en människa blir i stillhet och begrundar sin verklighet, och upplevelsen kan sträcka sig från rädsla till upprymdhet och acceptans av sin situation. Det innebär att ensamhet såväl som existentiell ensamhet är komplexa och har många uttryck och sannolikt bör bemötas på olika sätt. En begreppsanalys baserad på en litteraturgenomgång av både teori och empiri definierar existentiell ensamhet som en omedelbar medvetenhet om att vara fundamentalt separerad från andra människor och universum, och den medvetenheten är förknippad med en negativ upplevelse i form av sinnesstämning och känslor (Bolmsjö, Tengland \& Rämgård, 2019). I en litteraturgenomgång av 144 kvalitativa studier om begreppet ensamhet identifierades tre ensamheter: social ensamhet, emotionell ensamhet och existentiell ensamhet, där den existentiella bidrar med ett annat perspektiv genom att det inte enbart handlar om frånvaro av meningsfulla relationer utan känslan av att vara separerad från andra och resten av världen, ofta $\mathrm{i}$ samband med traumatiska händelser och dödlighet (Mansfield m.fl., 2019).

Existentiell ensamhet verkar vara ett fenomen som är svårt att fånga. Friedrichsen (2013) beskriver en tankeram för tre olika existentiella nivåer: existentiella tankar, existentiell oro och existentiell smärta. Existentiella tankar och funderingar behöver dock inte vara förknippade med smärta eller rädsla, men att sakna någon att samtala med när det finns behov eller att inte bli bekräftad i sin existens eller sina upplevelser i en utsatt situation kan leda till smärta och ensamhet. En studie visar att existentiell ensamhet hos äldre personer innebar att vara avskärmad från livet. De äldres upplevelser handlade om att vara instängda i en skör kropp, att bli bemötta som 
annorlunda, att sakna någon att dela viktiga tankar om livet med samt att sakna mening i livet (Sjöberg, Beck, Rasmussen \& Edberg, 2018). I likhet med ensamhet beskrivs att det kan finnas positiva aspekter av existentiell ensamhet, såsom en inre mognad när man har tagit sig igenom en period av djup ensamhet. Enligt Ettema med flera (2010) finns det tre dimensioner av existentiell ensamhet: som ett tillstånd, en erfarenhet och en process, som benämns inner growth om den bearbetas och ges utrymme. I Tornstams (2005) beskrivning av gerotranscendens betonas behovet att ha tid för stunder av stillhet. En del äldre personer har ett behov att grunna på saker och ting, som ett sätt att finna frid och sinnesro (Nyström, 2004). Det beskrivs som en inåtvänd process där den äldre personen för sin egen del grunnar, inte grubblar, och kan sägas vara ett sätt att använda sin livserfarenhet för att hantera olika situationer. Dock krävs vissa förutsättningar som att tillvaron inte får präglas av lidande, att man behöver en egen plats i stillhet och en tilltro till sig själv att man har förmåga att påverka och komma vidare. En person som har behov av stillhet och att grunna, kan däremot uppfattas som inaktiv och som någon som behöver aktiviteter och ha något att göra. Ett sådant exempel är en studie av Larsson, Edberg, Bolmsjö \& Rämgård (2019) som visar kontraster mellan den äldres upplevelser och närståendes uppfattningar om existentiell ensamhet. Studiens resultat beskriver den äldres upplevelse av meningslös väntan på andra och på att få hjälp i kontrast till närståendes uppfattning om brist på aktivitet som orsak till existentiell ensamhet. Ett annat exempel från studien är den äldres saknad av djupare kontakt och nära relationer i kontrast till närstående uppfattning om brist på sociala kontakter. Det är viktigt för vårdpersonal att kunna upptäcka existentiell ensamhet och förstå vad som kan skapa denna hos äldre personer och utgå från den äldres upplevelse i första hand, i stället för att utgå från andras eller sina egna uppfattningar och värderingar. Lika viktigt är att kunna urskilja vilka som har behov av ensamhet och vill vara för sig själva för att kunna bemöta var och en på det sätt som de önskar och har behov av.

\section{Åldrandet - en existentiell utmaning}

Åldrandet innebär förskjutningar i vardagen som handlar om den förändrade kroppen, men också om att bli kategoriserad som äldre (Alftberg, 2012). Det gäller för de flesta, oavsett den egna inställningen till åldrandet. Att bli äldre och åldras innebär livserfarenheter som kan ge ökad säkerhet och tillit till den egna förmågan att hantera livet och dess förändringar. Det innebär samtidigt för de flesta människor förluster av olika slag. Det kan handla om kroppsliga förluster och förmågor, förlust av sociala kontakter och rollförluster, till exempel att förlora sin livspartner eller vänner. Synen 
på, och upplevelsen av, ålderdomen varierar mellan människor. Det finns de som upplever sin ålderdom som en tid som domineras av förluster medan det finns andra som finner en känsla av frid och ro. I en studie om ensamhet bland äldre personer över 85 år beskrevs ensamhet på liknande sätt: å ena sidan som övergivenhet och att leva med förluster och å andra sidan som att leva i tillförsikt och frihet (Graneheim \& Lundman, 2010). Det är sannolikt båda delarna för många människor, sett över tid.

Det är komplext att åldras; en unik och ny erfarenhet för varje person och en ständigt pågående process fram tills döden inträffar. Detta visar även Broströms (2014) avhandling där de friska äldre som deltog hade inställningen att livet pågår fram till döden och att de i tanken pendlade mellan olika tidshorisonter. Bodil Jönsson (2011) skriver i sin bok När horisonten flyttar sig att åldrandet är en lång förändringsprocess som kan vara lika krävande som att bli vuxen. För de allra flesta innebär åldrandet att så småningom bli beroende av andra människor, antingen av närstående som informella vårdare eller att bli beroende av vård och omsorg och formella vårdare under den sista tiden av livet. Förluster är en annan aspekt av att åldras (Baltes \& Smith, 2003). Det innebär ofta fysiska förluster där kroppens funktioner på olika sätt tappar i styrka och snabbhet, å andra sidan kan erfarenhet och livskunskap innebära en ökad säkerhet och ett ökat behov av att få tänka tillbaka på sitt liv och sätta det $\mathrm{i}$ ett sammanhang (Andersson, Hallberg \& Edberg, 2008; Santamäki Fischer, Norberg \& Lundman, 2008). De fysiska förlusterna kan på olika sätt innebära att en äldre person blir beroende av andra personer såsom familj, vänner och kanske så småningom av personer utanför den privata sfären i form av formell vård utförd av professionella.

Åldrandet delas ibland in i en tredje och en fjärde ålder som visar att det finns olika faser med olika utmaningar, den är dock inte bunden vid en specifik ålder. Den tredje åldern startar i samband med pensioneringen och innebär vanligen goda funktioner och god hälsa. Det är en period av aktivitet, delaktighet och välbefinnande och kanske till och med en känsla av frihet. Den fjärde åldern innebär en nedsatt funktion och hälsa som i sin tur kan påverka både upplevd hälsa och livskvalitet (Ernsth Bravell, 2013). Att drabbas av sjukdom och bli beroende innebär en övergång från att vara frisk till sjuk, från oberoende till beroende och skör, det som i litteraturen beskrivs som frailty. Detta benämner Fillit och Butler (2009) som frailty identity crisis. Franklin, Ternestedt och Nordenfelt (2006) beskriver att självbilden påverkas av att personen inte längre känner igen sin kropp och blir beroende av andras hjälp. Den äldre personen måste anpassa sig både psykologiskt och emotionellt till den 
tilltagande skörheten, kroppens förändringar liksom till förlusten av fysiskt oberoende. Att gå från den tredje åldern, att vara frisk äldre, till den fjärde åldern med begränsad fysisk kapacitet innebär en övergång från ett tillstånd till ett annat med förändring och nya förutsättningar, det som kallas transition (Baltes \& Smith, 2003; Nilsson, Sarvimäki \& Ekman, 2000).

Transition är, förutom ett tillstånd, en process som varierar över tid med flera olika känslor, såsom ambivalens och ovisshet (Meleis, Sawyer, Im, Hilfinger Messias \& Schumacher, 2000; Norberg, Lundman, Nygren \& Santamäki Fischer, 2012). Den innefattar även de allra äldsta (Nilsson m.fl., 2000). Transitioner kan pågå samtidigt, vilket kan innebära flera parallella processer trots att de kommer ur samma situation, exempelvis att drabbas av sjukdom som förändrar livet och samtidigt flytta till särskilt boende. Under processen kan kritiska punkter uppstå, särskilt i perioder av ovisshet (Meleis m.fl., 2000). Vid sådana tillfällen behöver vårdpersonal vara uppmärksamma på den äldre personen för att kunna vara ett stöd. Det finns koppling mellan transitioner och gränssituationer. Enligt Jaspers är gränssituationer inget som undgår människan utan är en del av att existera (Benktson, 1976). Hit räknas död, lidande, kamp, slumpen och skuld och de är kopplade till situationer som uppstår under livets gång. Gränssituationer innebär att inte kunna fly från en situation som uppstått (Arlebrink, 2012). Det går inte att gå vare sig framåt eller bakåt i situationen och ovisshet finns med som en komponent. Både transitioner och gränssituationer är en del av livet och därmed en del av människans livshistoria. Detta är något som vårdpersonal behöver ha kännedom om och vara lyhörda inför, för att kunna möta den äldre personen i, för att inte ytterligare lidande ska uppstå.

Enligt makarna Eriksons utvecklingsteori går individen igenom nio olika steg (Erikson \& Erikson, 1997). De steg som sker i vuxen ålder handlar om närhet kontra isolering, generativitet kontra stagnation och integritet kontra förtvivlan. De dygder som följer med dessa är kärlek, omsorg och vishet under förutsättning att individen utvecklas i den riktningen. Det nionde steget utvecklades av Joan Erikson när hon själv var över 90 år eftersom det var först då hon själv fick insikt i hur det var att åldras. Joan menade att det ofta är en kamp i vardagen att behålla de positiva aspekterna av åldrandet i förgrunden. När kroppen tappar både styrka och kontroll infinner sig ovissheten om vad som ska komma härnäst. Hopp och tillit till framtiden är inte längre självklart. De positiva aspekterna beskrivs som en minskad självcentrering, ett minskat behov av materiella ting och en känsla av gemenskap med naturen och tidigare generationer (Erikson \& Erikson, 1997). Känslan av gemenskap 
med naturen och tidigare generationer innebär gränsöverskridande över tid och rum, det som Tornstam (2005) benämner som gerotranscendens. Gerotranscendens har likheter med det nionde steget i Eriksons teori, och innebär att den äldre personen omdefinierar sig själv och i relation till andra. Teorin om gerotranscendens beskrivs också som att den äldre får en ny förståelse för grundläggande existentiella frågor, där man blir allt mindre intresserad av det materiella.

Trots sjukdom och ett omfattande beroende av andra människor visar flera studier att vardagliga händelser har en stor betydelse som visar att den äldre fortfarande har ett värde för andra (Alftberg, 2012; Andersson m.fl., 2008; Franklin m.fl., 2006). Naturens växlingar och vackert väder uppskattades och fanns som en del i en strategi som gick ut på att njuta av ögonblicket. Kroppens betydelse för välbefinnande respektive illabefinnande och ensamhet, isolering och existentiell ensamhet har beskrivits i flera studier (Ebrahimi, Wilhelmson, Eklund, Dea Moore \& Jakobsson, 2013; Sand \& Strang, 2006; Hemberg, Nyqvist \& Näsman, 2019). När man inte längre kunde lita på sin kropp på grund av skörhet och sjukdom ledde det till en känsla av ovisshet (Ebrahimi m.fl., 2013) och utsatthet (Hemberg m.fl., 2019). Vårdsituationer som innebär att ha liten, eller ingen, kontroll och uppleva sig vara i händerna på andra kan innebära en upplevelse av sårbarhet hos den äldre (Abley, Bond \& Robinson, 2011). Däremot finns det även positiva aspekter av den sårbarhet som kan följa med beroende, om den bejakas och bemöts. Att vara sårbar och beroende av andra människor har också beskrivits i termer av att fortfarande ha förmåga att känna och att vara en levande person (Sarvimäki \& Stenbock-Hult, 2014). Beroende kan för vissa vara både sorgligt och obehagligt, men för andra inge en känsla av trygghet och välbehag då en annan människa visar omsorg (Whitaker, 2010). Sårbarheten bör ses som ett av människans villkor och därmed något som finns som ett gemensamt villkor för oss människor. Sårbarheten ska inte ses som en defekt utan som en del av att vara människa, något som gör oss dynamiska och ger oss en öppenhet mot andra. Det kan vårdpersonal träna sig i att känna igen, och erkänna hos både sig själv och den andre för att på så sätt möta den äldre som en unik person.

\section{Sköra äldre personer i vården}

Att beskriva sköra äldre personer är sannolikt lika svårt som att beskriva andra grupper, såsom personer i medelåldern eller tonåringar. Människor kan på gruppnivå ha egenskaper med gemensamma aspekter, men det är svårt att sammanfatta utan att förbise det unika och personliga hos varje person. Däremot kan det finnas aspekter 
hos sköra äldre personer i relation till åldrandet och den fysiska skörheten som har betydelse i vården. I Sverige liksom i övriga världen ökar andelen äldre personer. Drygt en halv miljon personer är 80 år eller äldre och utgör omkring 5 procent av Sveriges befolkning och andelen beräknas öka de närmaste åren både i Sverige och globalt (Socialstyrelsen, 2019; WHO, 2015). Medellivslängden år 2018 var för kvinnor 84,25 år och för män 80,78 år (SCB, 2019). Den ökade medellivslängden innebär att vi lever längre och håller oss friska längre, men även att allt fler människor lever längre med flera olika diagnoser och sjukdomar, ibland kallat samsjuklighet eller multisjuklighet. Det innebär också att fler äldre personer bor kvar hemma med omfattande vårdbehov, eftersom det är möjligt att ge allt mer avancerad och teknisk sjukvård i hemmet (Socialstyrelsen, 2019).

Vård och omsorg samt hälso- och sjukvård till äldre personer ges i ett flertal olika vårdformer. Ansvaret är reglerat i lagar och är fördelat mellan kommuner och landsting/regioner. Vården ges i kommunerna, antingen i det egna hemmet eller på särskilt boende, via primärvården eller som sjukhusvård, i offentlig eller privat regi. Det finns ett flertal olika boendeformer i kommunerna förutom särskilt boende, såsom trygghetsboende och seniorboende. Även andra tjänster kan ges i kommuner efter behov (Socialstyrelsen, 2016). Kvarboendeprincipen som är en ledande princip i äldreomsorgen och i policyer, internationellt benämnt ageing in place, innebär att man så långt det är möjligt bor kvar hemma med vård och omsorgsinsatser. Principen innebär också att den äldre personen, efter inflyttning till särskilt boende, inte behöver byta boendeform vid försämring, det vill säga att vården och omsorgen flyttar till personen och inte tvärtom (SBU, 2019). En svensk longitudinell studie baserad på The Swedish National Study on Aging and Care (SNAC), visade att vistelsetiden för äldre personer på särskilt boende minskade under åren 2006-2012. Det gällde särskilt dem som dog en kort tid efter inflyttning, där det var en markant minskning i antalet vistelsedagar (Schön, Lagergren \& Kåreholt, 2016). Det betyder att det finns äldre personer som endast vistas en kort tid i livets slut på särskilt boende. Socialstyrelsens statistik visar att sex månader efter inflyttning till särskilt boende har 19 procent av kvinnorna avlidit och 28 procent av männen, och enligt motsvarande siffror efter fyra år bor 27 procent av kvinnorna och 17 procent av männen kvar (Socialstyrelsen, 2019). Det innebär att behoven hos de som bor på särskilt boende varierar, från sociala aktiviteter och stimulans, hälso- och sjukvård samt rehabilitering till palliativ vård i livets slutskede, vilket i sin tur ställer stora krav på personalen (Schön m.fl., 2016). Palliativ vård ges som allmän eller specialiserad palliativ vård och kan ges på särskilt boende, men också via hemsjukvård eller via avancerad sjukvård i hemmet (ASIH), 
och ibland i samarbete mellan de två. Varje år dör omkring 90000 personer i Sverige och mer än hälften är 80 år eller äldre (SCB, 2019).

I takt med åldrandet tillkommer biologiska förändringar som i sig inte är sjukliga, utan en del av att åldras. Det primära åldrandet tillhör åldrandet som sker hos alla individer oavsett miljö. Det sekundära åldrandet innebär sjuklighet och kan ses som en effekt eller förstärkning av det primära åldrandet, i kombination med påverkan av miljö och livsstil, men det sekundära åldrandet drabbar inte alla (Ernsth Bravell, 2017). Däremot ökar risken för vissa sjukdomar med ökad ålder och i kombination med arv och miljö. Förändringar som tillhör det naturliga åldrandet sker vanligen gradvis och långsamt, medan snabba förändringar snarare hör samman med sjukdom. De flesta personer i den äldre befolkningen är relativt friska; däremot ökar andelen personer med sjukdomar och funktionsnedsättningar såsom stroke, osteoporos, demenssjukdom, nedsatt hörsel och syn samt nedsatt rörelseförmåga med stigande ålder (Larsson \& Thorslund, 2006). Åldrandet innebär dessutom att kroppen och dess förmåga att hantera förändringar, inre såväl som yttre, minskar liksom kroppens förmåga till homeodynamik, det vill säga att anpassa sig till förändringar (Rattan, 2006). Det betyder att åldrandet på ett biologiskt och fysiskt plan handlar om att gå från ett tillstånd med god förmåga att anpassa sig till förändringar till att vara $\mathrm{i}$ en sårbarhetszon, vilket sker på alla nivåer i kroppen. Det innebär exempelvis att även mindre förändringar kan leda till stora påfrestningar för en skör äldre person, där omvårdnad och vårdmiljön har betydelse för att lindra lidande och bidra till återhämtning. En studie visade att det fanns olika mönster för hur förluster hanterades: de som klarade av att balansera förändringar och förluster, de som kämpade för att hantera den nya tillvaron och de som upplevde förlusterna som överväldigande (Lloyd, Kendall, Starr \& Murray, 2016). Att leva med skörhet och komplexa hälsoproblem handlade om att leva med pågående och skiftande avbrott som påverkade vardagen. Det innebar känslor som rädsla, oro och ovisshet eftersom de kroppsliga förändringarna inte var förhandlingsbara och det som man tidigare tagit för givet inte längre var en självklarhet eller förenat med risker (Skilbeck, Arthur \& Seymour, 2018). För vårdpersonal är det av stor vikt att identifiera och anpassa sitt bemötande efter de psykologiska, sociala och existentiella behov som den äldre har som en konsekvens av skörhet. Det gäller i synnerhet de äldre som har svårast att hantera förluster och som av Lloyd med flera (2016) beskrivs som att kopplingen har brustit mellan den person man en gång varit och den man blivit. De äldre beskrev det som att vara en åskådare i sitt eget liv och kände förtvivlan över att ha förlorat sin självständighet och förmåga att välja hur man lever sitt liv. 


\section{Existentiella livsvillkor av betydelse}

Existentiella frågor väcks hos oss alla vid olika tillfällen i livet, vilket innebär att vårdpersonal kommer i kontakt med dessa frågor i mötet med äldre personer i behov av vård och omsorg. Som människor lever vi i ett sammanhang, i en värld tillsammans med andra människor. Inom vård och omsorg möts sköra äldre personer och vårdpersonal $\mathrm{i}$ ett vårdande sammanhang. I dessa ständiga möten behöver vårdpersonal vara närvarande och se den äldre personen som en människa med unika och personliga behov. Enligt Irvin Yalom (1980) finns det livsvillkor för människan som handlar om att vi i avgörande ögonblick står ensamma, att vi har frihet att bestämma över vårt liv, att vi söker mening och att vi alla ska dö. Det är livsvillkor som vi har gemensamt och det innebär att vi är ensamma i världen i en mening och samtidigt ensamma tillsammans med andra. För att jämna ut asymmetrin i vårdrelationen behöver den som vårdar bli klar över vilka existentiella livsvillkor som är gemensamma med patientens, liksom vad som skiljer dem åt (Schuster, 2006). Ett sådant erkännande innebär att patienten får en annan status, en mer jämbördig relation och samtidigt ses om en egen unik person.

Ur ett existentiellt perspektiv kan utveckling ses som att ha förmåga och kraft att leva i tiden (van Deurzen, 1998). Vidare menar van Deurzen, filosof och existentiell psykoterapeut, att en acceptans av det förgångna kan göra nuet acceptabelt och ge en tillit till framtiden. Utveckling kan också ses som en förmåga att hantera sitt eget åldrande och sin omvandlingsprocess där varje person är medveten om sin oundvikliga utveckling från födsel till döden. Människan befinner sig på ett kontinuum mellan två poler, som liv och död, gott och ont, aktivt och passivt samt närhet och distans där människans existens ofta är paradoxal och komplex. Mening med livet och människans existens finns beskrivet av flera filosofer. Enligt Frankl (2006) strävar människan efter mening som en primär kraft i livet. Den måste dock sökas och finnas av människan själv för att få den mening och tillfredsställelse som eftersträvas. Frankl använder också begreppet "det existentiella vakuumet". Det uppstår när mening saknas i livet och tar sig uttryck i tristess och meningslöshet $\mathrm{i}$ vardagen och i livet i stort. Döden och lidandet är för många meningslöst och berövar livet dess mening. Frankl betonar möjligheterna i livet och menar att möjligheter är en förgänglig aspekt av livet eftersom en möjlighet så snart den har gått i uppfyllelse finns i det förflutna. Mot bakgrund av detta menas att vårt liv och vår existens trots dess förgänglighet inte är meningslös utan att vi har val att göra, val som innebär att förverkliga möjligheter. Dock ser de flesta förgängligheten, i stället för meningen med det förgångna. Frankl (2006) menar att det förgångna inrymmer såväl gärningar och 
glädje som lidande. Genom att sätta ord på händelser och därigenom sätta händelserna i sitt sammanhang kan det förgångna, så som Frankl beskriver, få mening. Därför är människans berättelser viktiga. Berättelsen ändras allteftersom vi lever, liksom vi själva förändras. Livsberättelser kan också ses som meningsskapande och det som binder oss samman, som ett slags kitt mellan den jag varit och den är jag är i dag, och handlar om erkännande och identitet, både inför andra och inför mig själv (Jenner \& Henriksson, 2008). Vi har också en existentiell identitet, vem vi är som människa. Identiteten är dynamisk och det kan finnas fler berättelser som beskriver en person, vem personen är. Enligt Ricœur (2011) är människan en talande människa genom språket, en handlande människa, en berättande människa och en människa med ansvar. Minnet har betydelse för att hålla ihop oss själva som personer. När vi befinner oss i utsatta situationer, när existensen är hotad, behöver vi hjälp från andra som berättar om oss. Det finns många olika berättelser om var och en av oss, berättade både av oss själva och av andra. Den äldre personens egen berättelse minskar inte i värde för att fler berättelser läggs till samlingen.

\section{Vårdpersonalens inställning och attityder}

Vårdpersonalens inställning och attityd till äldre personer kan påverkas av olika föreställningar i samhället. Trots ökade kunskaper om äldre och åldrade finns fortfarande stereotypiska föreställningar om äldre personer (Tornstam, 2007). En avhandling om konstruktioner av äldre i samhället (Nilsson, 2008) där textmaterial från dagstidningar, ett pensionärsparti samt en offentlig utredning jämförts och analyserats, visade att äldre personer är några vi talar om eller till men sällan en position vi talar utifrån. I en studie av Franklin med flera (2006) bland äldre på äldreboende framkom att de upplevde sig försummade och stereotypt behandlade av personalen. I en systematisk litteraturgenomgång av ageism i olika åldrar visade det sig att det fanns skilda orsaker till ageism bland yngre vuxna jämfört med äldre vuxna (Bodner, 2009). Bland yngre var det en omedveten försvarsstrategi mot dödsångest som låg bakom stereotypiska attityder. Bland äldre personer var det i stället synen på äldre som en grupp med låg status vilket man inte ville identifiera sig med (Bodner, 2009; Lev, Wurm \& Ayalon, 2018). Negativa attityder mot det egna jaget kan också internaliseras i kroppen och förkroppsligas, och kan ha påverkan på hälsa, livslängd och kognitiva funktioner (Lev, Wurm \& Ayalon, 2018). Därför är det viktigt att uppmärksamma stereotypiska uttryck och attityder eftersom de kan utgöra en risk att sådana stereotypa uppfattningar begränsar vårt sätt att se den äldre personen som en unik person och med de egenskaper och kvaliteter som varje person har. 
På särskilda boende och i hemvården utvecklas relationer mellan den äldre och vårdpersonal över längre tid, vilket skulle kunna ses som att dela en vardag över tid. En studie om sjuksköterskor och deras uppfattningar om sitt arbete på särskilt boende och $\mathrm{i}$ hemvård visade att det som värderades högt var att kunna skapa långvariga relationer med de äldre och deras familjer liksom att utöva en personcentrerad omvårdnad (Carlson, Rämgård, Bolmsjö \& Bengtsson, 2014). Det verkar dock inte vara självklart att äldre och vårdpersonal har en gemensam och delad vardag. I en studie om etiska problem i vardagen uttrycks det som "att vara i samma värld utan att mötas" (Bolmsjö, Sandman \& Andersson, 2006). Österlind (2009) visar i sina resultat som bygger på individuella intervjuer med äldre personer och fokusgruppsintervjuer med vårdpersonal, att trots att de äldre och vårdpersonalen befinner sig på samma plats existerade två kulturer, där personalens kultur och attityder var överordnade de äldres. Även Harnett (2010) visar liknande resultat där en rutinkultur och trivialiseringsretorik hindrar de äldres möjligheter till inflytande. En enkätundersökning om attityder bland sjuksköterskor, undersköterskor och sjuksköterskestudenter inom äldrevård tyder på att utbildning och högre ålder bland vårdpersonalen främjar en positiv attityd och inställning till äldre (Engström \& Fagerberg, 2011). Samtidigt visade en systematisk litteraturgenomgång av Liu, Norman och While (2013) att sjuksköterskors och sjuksköterskestudenters attityder till äldre personer är komplexa och att varken ålder, kön eller utbildningsnivå var konsekvent förenliga med en positiv attityd. Däremot verkade intresse av att arbeta med äldre personer samt kunskap om åldrandet vara associerat med positiva attityder.

\section{Vårdpersonalens utmaningar i olika vårdkontexter}

Vårdpersonalen ställs inför olika utmaningar i mötet med sköra äldre personer och där vårdkontextens olika förutsättningar påverkar. Wolf, Ekman och Dellenborg (2012) beskriver vilken utmaning tempo, ljud, ljus och vårdens inriktning innebär för personalen för att kunna fokusera och anpassa sig efter den sköra äldres behov. Exempelvis kan den fysiska miljön på en vårdavdelning vara anpassad för övervakning och livsuppehållande åtgärder, utan att ge utrymme för enskilda samtal, varken plats- eller tidsmässigt. Rutinerna är oftast anpassade efter vårdens aktiviteter och indelade i morgon, kväll och natt. I denna miljö kan det för personalen vara en utmaning att, i ofta tidsbegränsade möten, klara av att växla perspektiv, från att vara uppgiftsorienterad till att vara en samtalspartner om djupare existentiella frågor (Udo, Danielson \& Melin-Johansson, 2013). En etnografisk studie på en medicinsk 
avdelning för äldre personer visade att sjuksköterskor använde olika röster beroende på syfte eller situation. Vid tidsbrist blev till exempel "maktrösten", som var distanserad och exkluderande, framträdande, annars var den vanligaste rösten den "medicinska" som var uppgiftsorienterad och enkelriktad. Det innebar samtidigt att de andra två rösterna, "sjuksköterskerösten" och den "pedagogiska rösten", fick stå tillbaka (Johnsson, Boman, Wagman \& Pennbrant, 2018). Tidsbrist verkar alltså påverka i vilken grad personalen fokuserar på uppgiften eller relationen och hur det tar sig uttryck. Beck (2013) fann i sin avhandling att vårdpersonal som arbetade på särskilt boende upplevde att de var tvungna att fokusera på praktiska uppgifter i stället för på relationen, vilket skapade ett dilemma för dem. Det var först vid vård i livets slut som relationen fick ta ett större utrymme. Det skapade skuldkänslor hos personalen att inte få arbeta enligt sin övertygelse. Dessutom krävs det kunskap och förståelse om de gränssituationer och transitioner som de äldre kan befinna sig i, för att kunna ge adekvat stöd. Det krävs också ömsesidiga och genuina möten och ett vårdklimat som främjar sådana möten (Finfgeld-Connet, 2008). Eftersom existentiella funderingar ofta uttrycks i vaga formuleringar (Sundler m.fl., 2016) kan det finnas en risk att vårdpersonalen inte uppfattar signalerna som den äldre personen ger, med oro och existentiell ensamhet som följd. Det behövs dock ytterligare forskning om personalens erfarenhet av att möta existentiell ensamhet, liksom hur de beskriver och hanterar den i olika vårdkontexter.

Det finns flera utmaningar i personalens vardag för att kunna möta den äldres unika behov och preferenser. Som personal är många situationer i arbetsvardagen återkommande, men för de äldre kan det vara en unik situation, där tidigare erfarenhet inte räcker till eller när framtiden är oviss. Ett sådant sammanhang är vid utskrivningar från sjukhus när den äldre personen lever i ovisshet om sin framtid. I en studie av Kydd (2008) framkom att ovissheten, vid exempelvis väntan på utskrivning efter en sjukhusvistelse, skapar oro och ångest, vilket sällan uppmärksammades av vårdpersonalen. En annan aspekt är när vårdens rutiner och strukturer påverkar den äldres vardag. I en studie om sköra äldre personers erfarenheter av att bo hemma beskrivs hur de äldre skapade olika strategier för att hantera den förändrade kroppen och dess kapacitet genom att anpassa sina dagliga rutiner på olika sätt. Här kunde vårdpersonal störa dessa rutiner genom att komma för tidigt eller för sent och därmed störa dagsrytmen som för den äldre var av stor betydelse (Nicholson, Meyer, Flatley \& Holman, 2013). Det kan ställas i kontrast till vårdpersonalens arbetsvardag där många uppgifter ska utföras under en ofta begränsad tid. Därför är det särskilt viktigt 
att som personal vara uppmärksam på varje persons sätt att leva och vad som är av betydelse, samt att tiden kan upplevas olika.

Den palliativa vården stödjer sig på en palliativ vårdfilosofi, men i vård och omsorg och i hälso-och sjukvård finns vanligtvis inte någon gemensam vårdfilosofi när det gäller äldre personer. I stället finns värdegrunder på organisationsnivå och/eller på lokal nivå. En nationell värdegrund infördes i äldreomsorgen 2012 (SOSFS 2012:3) som betonar den äldre personens självständighet, välbefinnande, trygghet och en meningsfull tillvaro där kontinuitet och sociala behov ska beaktas. Däremot nämns inte existentiella behov förutom att det ska vara en meningsfull tillvaro. I den palliativa vårdfilosofin finns existentiella behov uttalade jämsides med fysiska, psykologiska och sociala behov. Det indikerar att personal har olika förutsättningar och förväntningar på sig från sin arbetsgivare.

\section{Goda möten i vården}

Goda möten skapas tillsammans, även om vårdpersonal har det huvudsakliga ansvaret för att det över huvud taget blir ett möte. Det kan handla om att initiera, fånga signaler som den äldre personen ger om behov av bekräftelse, hjälp och stöd eller samtala om det som är viktigt. Wadensten (2005) menar att det behövs en ökad medvetenhet hos vårdpersonalen för hur och vad man som personal samtalar med den äldre om eftersom det i sin tur påverkar klimatet på avdelningen. Westin och Danielson (2007) beskriver äldres upplevelser av det goda mötet som att "vara någon" och att "vara i en gemenskap". Det kan vara ett uttryck för den relation som Martin Buber benämner som jag-du. Buber beskriver två dimensioner av relationer, jag-du eller jag-det (Buber, 1994). I jag-du-relationen möts människor i ett möte, på ett jämlikt plan, trots olika formella positioner och olikheter dem emellan. I en jag-det-relation ses den ena parten som ett objekt. Att dela gemensamma intressen och föra samtal på ett sätt som båda parter uppskattade, ledde enligt Westin och Danielson (2007) till ett meningsfullt liv för den äldre. Samtalen som handlade om de äldres egna erfarenheter och tankar om det som varit, innebar att möten med vårdpersonalen inte enbart kretsade kring sjukdom och andra vårdrelaterade uppgifter (Westin \& Danielson, 2007). Enligt en studie om vårdplaneringsmöten har personens sinnesstämning betydelse för hur mötet upplevs (Lindberg, Ekebergh, Persson \& Hörberg, 2015). Parternas sinnesstämning kunde skilja sig åt på det sättet att den äldres sinnesstämning var kopplad till dennes livssituation medan vårdpersonalens sinnesstämning var kopplad till professionens uppgift, vilket påverkade både känslor och relationerna i mötet. Det gäller sannolikt 
även i andra vårdmöten och genom att vårdpersonal är öppen för, och bekräftar patientens stämning, kan ett vårdande möte skapas. Lindberg (2014) menar att goda relationer är en förutsättning för den vårdande relationen och det är vårdpersonalen som har makt att bekräfta den äldre eller avvisa dennes önskan om vård. Enligt Lundin, Berg och Hellström Muhli (2013) tolkade vårdpersonal välmående hos de äldre som att vara existentiellt berörd och det innebar enligt deras tolkning att som äldre person känna frihet att välja, att känna glädje och närhet till någon eller något, vilket skapade välbefinnande. Situationer som uppstått långt tidigare i livet och med kopplingar till känslan av existentiell ensamhet skulle kunna lindras genom att dela upplevelsen och tillvaron med andra. I vårdsammanhang skulle det innebära att patientens livsberättelse blir en del av samtalet. Existentiella behov behöver uppmärksammas och det har genomförts olika projekt i syfte att möta äldre personers existentiella behov i form av samtalsgrupper (Rosenberg, 2010; Ranung \& Åhlfeldt, 2018; Lindahl, 2019) där existentiella frågor om livet och döden, samt åldrandet har diskuterats. Om personal ska kunna samtala med äldre personer om existentiella frågor behöver även de få möjlighet att i grupp diskutera och reflektera över frågor om liv och död.

För att skapa goda möten krävs vissa förutsättningar och det finns en risk att inbyggda strukturer $\mathrm{i}$ en organisation och vårdens organisering påverkar och begränsar personalens möjligheter att ge en god vård. Vårdande beskrivs som en mellanmänsklig interaktion som bygger på tanken att vårdande är en del av att vara människa (Finfgeld-Connet, 2008; McCormack \& McCance, 2010). För att en personcentrerad vård ska fungera i praktiken behöver det finnas förutsättningar på flera nivåer: individ, grupp samt organisationsnivå. McCormack, Dewing och McCance (2011) menar att den stora utmaningen är att gå från personcentrerade möten till en personcentrerad kultur både i arbetsgrupp och i organisation. Sjögren (2013) visade en samvariation mellan en gemensamt överenskommen värdegrund och personcentrerad vård. Det kan illustreras i en studie av Edvardsson, Varrailhon och Edvardsson (2014) som visar hur personalen främjar personcentrerad vård genom att vara engagerade i mötet med de äldre, att involvera dem i det dagliga livet på boendet samt att kontinuerligt efterfråga de äldres preferenser genom att erbjuda val och respektera dem. Personalen beskrev ett aktivt förhållningssätt och hur de mötte de äldre med uppskattning som anpassades efter varje person. Den personliga omvårdnaden gavs också särskild uppmärksamhet, den uppfattades inte som uppgift utan i stället som en upplevelse och som ett tillfälle av välbehag för den äldre. Detta ligger i linje med fynd i en studie av Orrung Wallin (2013) där vårdpersonal beskrev mötet med den äldre som en betydelsefull komponent 
för upplevelsen av arbetstillfredsställelse. Dessa möten tog sin utgångspunkt "i det lilla" och bestod av en speciell samhörighet som skapades i nuet. En gemensam värdegrund i arbetsgruppen ansågs viktig för att ge en god vård, liksom glädje och humor, vilket personalen upplevde påverkade de äldre positivt.

\section{Volontärer i vården}

Volontärers involvering i vården skiljer sig åt i världen. I många länder är volontärer och frivilligsektorn en integrerad del i verksamheten, både på sjukhus och inom palliativ vård, men också i äldrevård. I kunskapsöversikten om äldreomsorgsforskning i Norden (Szebehely, 2005) konstaterades att det behövs mer forskning om relationen mellan frivilligorganisationerna och den offentliga äldreomsorgen. I en rapport från FN om volontärarbete globalt (United Nations Volunteers, 2018), betonas att det är viktigt att samarbeten med volontärer fokuserar på deras bidrag, det vill säga det som handlar om den positiva kraft som tillförs, deras frivillighet och relationsskapande. Om volontärer enbart ses som en möjlighet att få ett bidrag till verksamhet till en ringa kostnad och ett alternativ som inte kräver engagemang, så uteblir effekterna. I en rapport från Sköndalsinstitutet (2003) om volontärverksamhet lyftes problematiken om bristen på tid i äldreomsorgen, där personal har för lite tid att samtala och där de är hänvisade till "görandet" i stället för "varandet". Vidare beskrevs att volontärer skulle kunna tillgodose framför allt de äldres sociala behov, där ensamhet rimligtvis är en betydande aspekt.

I Sverige finns det aktiva volontärer och volontärföreningar. "Den tredje sektorn", som den kallas, består av idéburna organisationer, där kooperativa företag ingår samt en del stiftelser samt det civila samhället. Röda Korset, Svenska kyrkan och Sjukhuskyrkan, kommunala volontärföreningar samt Väntjänst är exempel på organisationer som organiserar frivilligarbete. Volontärbyrån som finns sedan 2002 fungerar som ett nav för olika volontärorganisationer och förmedlar uppdrag samt utbildar och stödjer föreningar (Volontärbyrån, u.å). I Norden har äldreomsorg en central roll i den nordiska välfärdsmodellen och den välfärdsmodellen skiljer sig åt mot dem i många andra länder (Szebehely, 2005). Det finns sedan många år forskning inom socialt arbete som har följt välfärden i samhället, om informell vård och anhöriga som vårdare, och den tredje sektorn. Forskning visar att det finns många informella vårdare som även är aktiva som volontärer. Informellt arbete är således inget hinder för att vara volontär (Jegermalm \& Jeppsson Grassman, 2013). Dessutom förekommer volontärarbete i alla åldrar och en undersökning baserad på telefonintervjuer visade 
att 51 procent av personer mellan 18 och 84 år bidrog med volontärarbete i någon form. Det var något vanligare med volontäruppdrag bland män än bland kvinnor (Jegermalm \& Grassman, 2009) och det vanligaste uppdraget var inom idrottsrörelsen (Olsson, Svedberg \& Jeppsson Grassman, 2005). Trots att antalet volontärer minskar med stigande ålder, var antalet timmar per volontär oförändrat (Jegermalm \& Grassman, 2009). Det innebär att de som fortfarande håller kvar vid sitt volontäruppdrag sannolikt trivs med det och har orken kvar att fortsätta.

Volontärer finns i olika vårdverksamheter: inom palliativ vård, särskilt boende och sjukhus. Däremot saknas det en översikt över vilka vårdverksamheter som har volontärer involverade och i så fall i vilken omfattning eller i vilka aktiviteter. När det gäller forskning om volontärer inom palliativ vård visade en studie från Canada att volontärarbete har fördelar för både patienter, deras familjer och för volontärerna själva (Claxton-Oldfield, 2015). För volontärerna själva bidrog det till en känsla av att göra skillnad och att få andra perspektiv på tillvaron. En svensk studie om volontärer i palliativ vård visade dock att det finns ett behov av stöd bland volontärer, med fokus på att möta existentiella frågor (Andersson \& Öhlén, 2005). Det finns däremot mer sparsamt med forskning om volontärer inom äldrevården och volontärers egna erfarenheter av att möta äldre personer, att möta deras ensamhet $\mathrm{i}$ allmänhet och existentiell ensamhet i synnerhet. Ett sådant perspektiv kan bidra med kunskap som är av betydelse för att öka förståelsen om ensamhet, men också för framtidens organisering av vård och omsorg.

\section{Enhetschefer i vård och omsorg}

Enhetschefer i vård och omsorg ansvarar för olika yrkesgrupper och vilka de har ansvar för kan variera mellan kommunerna på grund av olika sätt att organisera vården av äldre personer. Ibland kallas enhetschefer för första linjens chef, det vill säga den person som är medarbetarnas närmsta chef. De har ansvar för undersköterskor i hemtjänst och på särskilt boende. Den legitimerade personalen är dock inte alltid organisatoriskt knuten till enheten utan kan i vissa organisationer finnas i en egen enhet. I äldreomsorgen arbetar legitimerad personal, däribland 14100 sjuksköterskor, 2700 arbetsterapeuter, 1900 fysioterapeuter och ett fyrtiotal dietister (Socialstyrelsen, 2019). Läkarna arbetar inte i den kommunala organisationen. Istället är det regionerna som har arbetsgivaransvar och ansvarar för den medicinska kompetensen. Undersköterskor inom hemtjänsten, hemsjukvården eller på äldreboenden är Sveriges vanligaste yrke (SCB, 2020) med cirka 135000 anställda. Bland de som arbetar inom 
äldreomsorg är de flesta kvinnor. Bland undersköterskor, sjuksköterskor och arbetsterapeuter är mellan 91 och 94 procent kvinnor medan det bland fysioterapeuter är en något lägre andel (83 procent) (SCB, 2020; Socialstyrelsen, 2019). Även bland enhetschefer i vård och omsorg är de flest kvinnor, 86 procent.

Enhetschefer i vård och omsorg har ett verksamhetsansvar där administration, ekonomi och planering av bemanning ingår, liksom personalansvar med kompetensutveckling av personalen (Szebehely, Stranz \& Strandell, 2017; Törnquist, 2004). Äldreomsorgen är en verksamhet som är och har varit i ständig förändring sedan 1990talet och beskrivs av Stranz (2018) som förändringspräglad, där nya organisationsformer och arbetssätt kontinuerligt införs och tillkommer. Exempel på större förändringar som påverkat verksamheterna är införandet av Ädelreformen 1992 och införande av New Public Management under 90-talet, som medfört ett ökat uppföljningskrav av arbetet som bedrivs i verksamheterna. Därtill tillkom införandet av lagen om valfrihetssystem (LOV) 2009, vilket innebär att valet av utförare överlåts till den enskilde eller brukaren, i det här fallet den äldre (SFS 2008:962). Av landets 290 kommuner har 132 kommuner infört LOV (Sveriges Kommuner och Regioner, 2019). I samband med Ädelreformens införande fick den medicinska modellen stå tillbaka för en social omsorgsmodell där kontaktpersonskap, aktivering och individanpassning varit ledord och införts som arbetssätt (Stranz, 2018). En nationell värdegrund för äldreomsorgen infördes (SOSFS 2012:3) i syfte att stärka den äldre personens möjligheter att leva ett värdigt liv och känna välbefinnande.

Att arbeta $\mathrm{i}$ en verksamhet med ständiga förändringar ställer stora krav på enhetschefernas förmåga att leda och styra verksamheten. Törnquist (2004) beskriver att verksamhetskunskap och personlig kompetens, däribland människokännedom, är värdefulla kompetenser för enhetschefer i vård och omsorg. Kommunal äldreomsorg är en politiskt styrd organisation, vilket innebär att enhetschefen är begränsad av de beslut som kommer "uppifrån" (Nilsen, Wallerstedt, Behm \& Ahlström, 2018). I samma studie framkom att enhetscheferna upplevde att det var svårt att fokusera och arbeta med en specifik verksamhetsfråga, som här handlade om att införa evidensbaserad palliativ vård, eftersom det ständigt kommer nya beslut och lagändringar som påverkar verksamheten på enhetsnivå. En annan utmaning i att arbeta med verksamhetsutveckling är när rutinuppgifter och den dagliga verksamheten tar all tid i anspråk (Ellström, 2012). Att ha visioner och långsiktiga planer som ofta ändrades på grund av organisatoriska förändringar och beslut från ledningen, sågs som ett hinder, liksom att vara begränsad av ekonomi och krav på 
effektivitet (Håkanson m.fl., 2014). I Socialstyrelsens lägesrapport från 2012 beräknades att det fanns 5000 enhetschefer inom kommunal och enskilt driven äldreomsorg. Enligt deras beräkningar hade 37 procent av enhetscheferna högst en tvåårig eftergymnasial utbildning och 10 procent saknade eftergymnasial utbildning (Socialstyrelsen, 2012). Socialstyrelsen framhöll samtidigt att en viktig förutsättning för ett gott ledarskap var att cheferna har en god kunskapsgrund och inte alltför många medarbetare att leda. Efter införandet av den nationella värdegrunden fick Socialstyrelsen ett regeringsuppdrag att upphandla en ledarskapsutbildning, i form av en uppdragsutbildning på $30 \mathrm{hp}$ om bland annat värdegrund, lagstiftning och ledarskap. Satsningen var tidsbegränsad mellan 2013 och årsskiftet 2015/2016 (Socialdepartementet, 2012).

Ledarskapet har betydelse för hur verksamheten fungerar och personalens arbetsförhållanden. Det har även betydelse för att kunna implementera nya sätt att arbeta. I en studie av Nilsen med flera (2018) framhöll enhetscheferna sjuksköterskorna som centrala förebilder, vilket innebär att samarbetet mellan enhetschefer och sjuksköterskor kan vara avgörande för om nya arbetssätt framgångsrikt ska kunna implementeras. Vården och omsorgen är en verksamhet som står inför utmaningar eftersom en allt större andel äldre personer är i behov av vård. Det i sin tur medför att nya arbetssätt kan behöva utvecklas. Till exempel visade en nordisk studie om chefers och politikers oro och funderingar inför framtiden att de var medvetna om att de äldre hade komplexa behov, att vården framöver behöver fokusera på varje person och dennes värdighet samt att det finns ett behov av öppenhet inför att organisera på andra sätt (Finnbakk, Skovdahl, Störe Blix \& Fagerström, 2012). Därutöver är personalens arbetstillfredsställelse av vikt för att behålla personer med värdefull kompetens. Enligt Szebehely med flera (2017) finns ett samband mellan hur personalen upplever sin möjlighet att utöva inflytande över sin arbetsvardag och funderingar på att sluta. Samma rapport att visade att personalen upplevde att relationerna till de äldre var betydelsefulla och samtidigt upplevde de en otillräcklighet på grund av att de äldre inte fick tillräckligt med hjälp i relation till sina behov. Att under sådana förhållanden möta existentiella frågor och föra samtal om livet och döden kan ytterligare bidra med påfrestning, om man inte känner sig trygg och har stöd. Detta lyfts även i den nationella kvalitetsplanen (SOU 2017:21) där det påtalades att det finns ett behov av både kompentensutveckling och handledning till personal. Det finns dock sparsamt med kunskap om i vilken omfattning handledning erbjuds och i vilken omfattning personal ges stöd $i$ att föra existentiella samtal. 


\section{MOTIV FÖR AVHANDLINGEN}

När befolkningen blir allt äldre och allt fler äldre med komplexa vårdbehov är i behov av vård och omsorg behövs olika lösningar för att tillgodose deras behov. Vårdpersonal möter sköra äldre personer varje dag i vården. En del av dem har existentiella funderingar eller upplever existentiell ensamhet. Personalens erfarenheter kan ge en inblick i de äldres situation men erfarenheterna är även betydelsefulla för att förstå hur personalen själv påverkas i möten med de äldre. Volontärer skulle kunna bidra som samtalspartner och medmänniskor i möten med de äldre. Det finns forskning om frivilligas insatser i samhället, men det behövs ytterligare kunskap om frivilligorganisationers involvering $\mathrm{i}$ äldreomsorgen och volontärers erfarenheter av att möta existentiella frågor och existentiell ensamhet hos sköra äldre personer. I enhetschefernas uppdrag ligger att ge stöd till sin personal, såväl som att tillgodose de äldres behov. Det är oklart hur cheferna ser på stöd till vårdpersonal i att möta äldre personers existentiella behov och existentiella ensamhet liksom hur de uppfattar och förhåller sig till volontärers involvering i vård och omsorg. Personalens och volontärernas berättelser om sina möten med äldre personer som uttrycker existentiella funderingar eller existentiell ensamhet kan användas för att belysa vilken kompetens som finns, var det finns brister och om det finns ett behov av stöd till vårdpersonal och volontärer. Sådan kunskap är värdefull för chefer och beslutsfattare när de ska ta beslut och göra prioriteringar i en tid som präglas av begränsade ekonomiska resurser såväl som vikten av att behålla vårdpersonal som trivs med sitt arbete. 


\section{SYFTE}

Avhandlingens övergripande syfte var undersöka vårdpersonals och volontärers erfarenheter av att möta äldre personers existentiella ensamhet, vårdkontextens betydelse samt enhetschefers syn på stöd.

De specifika syftena var:

- Att utforska vårdpersonals erfarenheter av att möta äldre personer som de uppfattar uppleva existentiell ensamhet (I).

- Att ur vårdpersonals perspektiv, utforska existentiell ensamhet hos äldre personer i olika vårdkontexter (II).

- Att beskriva erfarenheten av att bli och att vara volontär, och möta äldre personers ensamhet $\mathrm{i}$ allmänhet och existentiell ensamhet i synnerhet (III).

- Att ur enhetschefers perspektiv, undersöka vårdpersonals och volontärers möjligheter och hinder, samt behov av stöd, i att möta äldre personers existentiella frågor (IV). 


\section{METOD}

Detta avhandlingsarbete är en del i ett större projekt, Existentiell ensamhet - en utmaning $i$ vården av sköra äldre personer, den så kallade LONE-studien (Edberg \& Bolmsjö, 2019). Det större projektet har som syfte att undersöka begreppet existentiell ensamhet, hur det upplevs av sköra äldre personer, deras närstående, hur personal inom olika vårdkontexter möter och uppfattar existentiell ensamhet hos äldre personer samt hur man kan upptäcka existentiell ensamhet. Utöver det genomfördes även en begreppsanalys baserad på litteratur och empiriska studier. Projektet har sedan kommit att även inkludera studier om närståendes egen existentiella ensamhet, anhörigkonsulenter, volontärer och enhetschefer inom vård och omsorg samt journalgranskning av existentiella behov hos äldre personer den sista tiden i livet. De olika studierna kommer tillsammans att utgöra grunden för att utveckla en så kallad komplex intervention (MRC, 2008) som syftar till att bland annat stödja vårdpersonal i dessa frågor. Denna avhandling ligger inom ramen för den så kallade utvecklingsfasen av interventionen. Enligt Medical Research Councils riktlinjer om design av komplexa interventioner (2008) är alla fyra faser viktiga, det vill säga utveckling, pilot, utvärdering och implementering för att skapa interventioner av hög kvalitet. Enligt MRC:s riktlinjer handlar utvecklingsfasen om att identifiera en kunskapsbas som kan ligga till grund för en kommande intervention.

Projektgruppen består av forskare från Högskolan Kristianstad, Malmö universitet, Lunds universitet och Palliativt utvecklingscentrum i Lund. I LONE-studien ingick inledningsvis tre doktorandprojekt: den äldres perspektiv, närståendes perspektiv och vårdpersonalens perspektiv. Datainsamlingen skedde i stort sett i samma verksamheter och under samma tidsperiod. Följande vårdkontexter ingick i datainsamlingen för de tre perspektiven: hemvård, särskilt boende, sjukhus, palliativ vård, primärvård och till personalperspektivet tillkom även ambulanssjukvård. Verksamheterna som var kopplade till projektet fick information om LONE-studien genom att personer i projektgruppen i olika konstellationer presenterade studiens upplägg, syfte och genomförande både inför enhetschefen och inför personalen i samband med arbetsplatsträffar. En kontaktperson från varje verksamhet som hjälpte till med att förmedla information och ta emot intresseanmälningar att delta i intervjuer kopplades 
till projektet. Det var också kontaktpersonerna som var behjälpliga med att samordna deltagare till personalintervjuerna, tid och plats för intervjuerna tillsammans med mig som doktorand. Det fanns ingen koppling mellan de äldre och vårdpersonalen, i den mening att de skulle ha vårdats av den vårdpersonal som deltagit i datainsamlingen.

LONE-studien har haft en referensgrupp där personer med erfarenhet från vård, utbildning, volontärverksamhet samt med anhörigperspektiv ingått. Den första träffen skedde våren 2016 och därefter har ytterligare fyra träffar genomförts.

\section{Design}

Denna avhandling har en explorativ design och består av tre kvalitativa delstudier och en kvantitativ delstudie (tabell 1). Designen av de fyra delstudierna har växt fram under avhandlingens gång. Delstudie I och II hade båda en explorativ design för att beskriva personalens erfarenheter av och uppfattningar om existentiell ensamhet bland äldre personer samt hur personalen förhåller sig och handlar i olika vårdkontexter. Baserat på resultaten väcktes nya forskningsfrågor. En fråga var om det fanns andra än vårdpersonal som den äldre kunde samtala med om sina existentiella funderingar och på så sätt lindra existentiell ensamhet, vilket ledde till en studie där volontärer involverades (III). Det väcktes också frågor om vilka förutsättningar som vårdpersonalen hade för, och vilket stöd de fick $i$, att möta existentiella frågor och existentiell ensamhet. Andra frågor handlade om i vilken omfattning det fanns volontärer i äldreomsorgen och hur de i så fall involverades, om det fanns hinder i organisationen för att involvera dem samt vilka aktiviteter volontärer deltog i. Därför vände vi oss till enhetschefer inom vård och omsorg med en enkät om deras syn på vårdpersonal och volontärer (IV). 


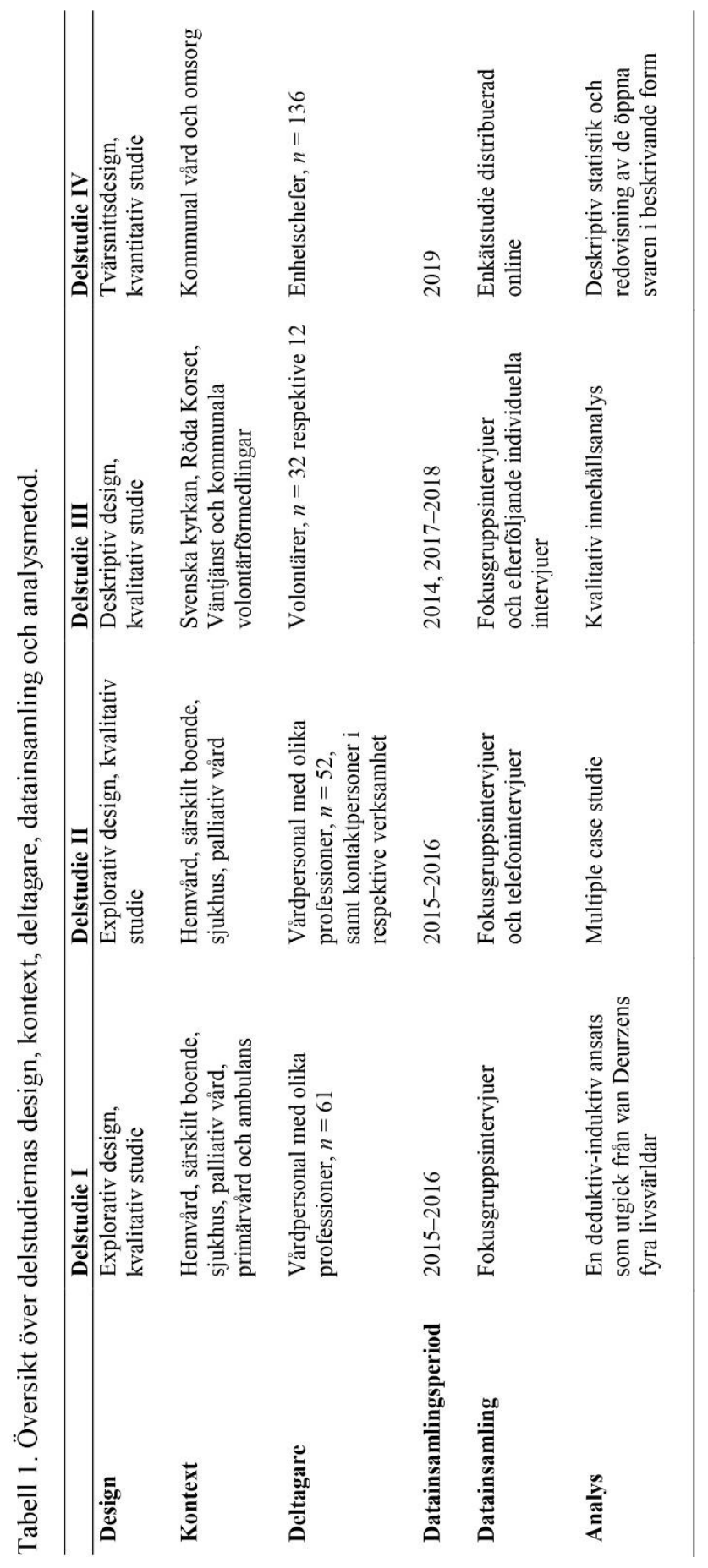




\section{Urval}

Urvalet till delstudie I och II var gemensamt. Totalt elva vårdverksamheter i södra delen av Sverige, i både större och mindre städer, ingick. För att få variation inkluderades olika vårdkontexter: hemvård, särskilt boende, sjukhus (medicinsk akutvård och ortopedi), palliativ vård, primärvård, samt ambulanssjukvård och urvalet baserades på maximum variation sampling (Polit \& Beck, 2012). Inklusionskriterier för att delta var att man arbetade inom verksamheten samt att man ville delta i en fokusgruppsintervju och samtala med kollegor om att möta existentiell ensamhet hos äldre personer. Deltagarna $(n=61)$ i de sammanlagt 11 fokusgruppsintervjuerna hade olika professioner, som undersköterska och vårdbiträde, sjuksköterska, läkare, arbetsterapeut, fysioterapeut, kurator samt biståndshandläggare (tabell 2). De flesta var undersköterskor/vårdbiträden och sjuksköterskor, 22 respektive 25 personer, medan övriga var fördelade på olika professioner. Alla de 61 personerna ingick $\mathrm{i}$ delstudie I. Anledningen till att inkludera så många olika professioner var att kunna fånga flera olika perspektiv. Trots att deltagarna hade olika funktioner och utförde olika uppgifter i relation till äldre personer kommer de fortsättningsvis i denna avhandling att omnämnas som vårdpersonal eller personal om inte den enskilda professionen har betydelse i sammanhanget. 
Tabell 2. Beskrivning av deltagarnas profession, yrkeserfarenhet, arbetslivserfarenhet samt vårdkontext (delstudie I).

$$
n=61
$$

Ålder, år

Range

26-68

Medel

49

Kön

Kvinnor

Män

\section{Profession}

Undersköterska/vårdbiträde

Sjuksköterska

Läkare

Arbetsterapeut

2

Fysioterapeut

Kurator

Biståndshandläggare

Yrkeserfarenhet i hälso- och sjukvård, år

$\begin{array}{lr}\text { Range } & 4-43 \\ \text { Medel } & 19\end{array}$

\section{Arbetslivserfarenhet i nuvarande}

organisation, år

Range

$0,5-42$

Medel

\section{Deltagare från varje vårdkontext}

Hemvård

Särskilt boende

Sjukhus

Palliativ vård

Primärvård 
Urvalet till delstudie II bestod av deltagarna i de nio fokusgruppsintervjuer som var genomförda inom vårdkontexterna hemvård, särskilt boende, sjukhus och specialiserade palliativa vårdverksamheter (vård i hemmet och slutenvårdsenheter). Då syftet var att utforska existentiell ensamhet i olika vårdkontexter valdes de vårdkontexter ut där sköra äldre personer framför allt befinner sig samt att det var väl avgränsade enheter som bedömdes lämpliga att studera (Stake, 1995). Totalt inkluderades sammanlagt 52 deltagare med olika professioner (tabell 3).

Tabell 3. Beskrivning av deltagarnas profession samt vårdkontext, $\mathrm{n}=52$ (delstudie II).

\begin{tabular}{|c|c|c|c|c|}
\hline Profession & Hemvård & $\begin{array}{l}\text { Särskilt } \\
\text { boende }\end{array}$ & Sjukhus & $\begin{array}{l}\text { Palliativ } \\
\text { vård }\end{array}$ \\
\hline & $n=16$ & $n=11$ & $n=9$ & $n=16$ \\
\hline $\begin{array}{l}\text { Undersköterska/vård- } \\
\text { biträde }\end{array}$ & 10 & 9 & 1 & 1 \\
\hline Sjuksköterska & 2 & 2 & 4 & 11 \\
\hline Läkare & - & - & 1 & 3 \\
\hline Arbetsterapeut & 1 & - & 1 & - \\
\hline Fysioterapeut & 2 & - & 1 & - \\
\hline Kurator & - & & 1 & 1 \\
\hline Biståndshandläggare & 1 & - & - & - \\
\hline
\end{tabular}

Urvalet till delstudie III baserade sig på maximum variation sampling (Polit \& Beck, 2012) i syfte att få variation och volontärer med olika bakgrund. Därför inkluderades volontärer från olika volontärorganisationer såsom Svenska kyrkan, Röda Korset, Väntjänst och kommunala volontärföreningar i södra delen av Sverige, i både större och mindre städer (tabell 4). De totalt 32 deltagarna i fokusgruppsintervjuer och individuella intervjuer hade samtliga själva anmält intresse för att delta. Förutom att deltagarna tillhörde olika organisationer hade de olika volontäruppdrag som hembesök, besök på särskilt boende eller sjukhus eller genom volontäruppdrag på lokala mötesplatser (tabell 5). Deras kontakter med de äldre varierade från tillfälliga kontakter till relationer som varade över flera år. 
Tolv deltagare som hade deltagit $\mathrm{i}$ en fokusgruppsintervju intervjuades även individuellt. Det var ett ändamålsenligt urval, där hänsyn togs till att personen bedömdes ha erfarenheter av värde för studien och där hänsyn även togs till att det fanns representation från alla inkluderade organisationer samt variation i ålder och professionsbakgrund (tabell 4). Sammanlagt tillfrågades 25 av deltagarna i fokusgrupperna om att delta i en individuell intervju. Av dessa avböjde fem personer, sju återkom inte och en person lämnade återbud med kort varsel. Alla som tillfrågades fick ett nytt brev med information om studien och varför vi var intresserade av volontärers roll i relation till äldre personers existentiella ensamhet.

Urvalet till delstudie IV bestod av slumpmässigt utvalda enhetschefer inom hemtjänst och särskilda boenden i Sverige (Dillman, Smyth \& Christian, 2014; Polit \& Beck, 2012). Inklusionskriterierna var att man skulle vara chef inom vård och omsorg i en kommun samt ha personalansvar. Deltagarna identifierades via Socialstyrelsens enhetsförteckning för Öppna jämförelser (Socialstyrelsen, 2018). Var åttonde enhet valdes ut av de totalt 4058 enheter för hemtjänst och särskilda boenden som ingår i Öppna jämförelser, sammanlagt 504 enheter. Respektive enhetschefs e-postadress eftersöktes därefter via kommunernas hemsidor eller kundcenter. Totalt 467 enhetschefer tog emot e-postmeddelandet efter att autosvaren räknats bort. Av dessa besvarade 56 personer enkäten efter första utskicket och ytterligare 81 personer innan enkäten stängdes, totalt 137 svar. Av de utskickade enkäterna kom 37 i retur som autosvar. Utöver det första meddelandet som genererade i 56 svar, skickades tre påminnelser ut, som var för sig genererade 35, 27 respektive 19 svar. Efter att ha kontrollerat att deltagarna hade angett att de hade personalansvar inkluderades 136 enhetschefer. Studien hade således en svarsfrekvens på 29 procent.

Av studiens 136 deltagare var majoriteten kvinnor (83 procent) med en medelålder av 51 år. Den vanligaste utbildningen bland deltagarna var socionom/social omsorg (40 procent) och sjuksköterska ( 24 procent). Nästan hälften av deltagarna (44 procent) hade mer än 10 års erfarenhet som chef inom vård och omsorg. Hälften arbetade som enhetschef inom hemtjänst och den andra hälften på särskilt boende eller i kombination med andra boendeformer (tabell 6). 
Tabell 4. Beskrivning av deltagarnas tillhörighet, erfarenhet som volontär och yrkesbakgrund (delstudie III).

$\begin{array}{lr}\text { Fokusgruppsintervjuer } & \text { Individuella intervjuer } \\ n=8 \text { med } 32 \text { deltagare } & n=12\end{array}$

$\begin{array}{lrr}\text { Ålder (år) } & & \\ \text { Range } & 46-87 & 47-76 \\ \text { Medel } & 69,5 & 69,5\end{array}$

Tillhörighet till respektive volontärorganisation (antal

personer)

Svenska kyrkan

$\begin{array}{rr}13 & 5 \\ 12 & 3 \\ 3 & 2 \\ 4 & 2\end{array}$

Kommunal volontärorganisation

Röda Korset

Väntjänst

2

Erfarenhet som volontär (år)*

$1-2$

$3-4$

$5-6$

$7-8$

9-10

$>10$

$\begin{array}{ll}5 & 3 \\ 6 & 3 \\ 7 & 4 \\ 2 & - \\ 1 & - \\ 3 & 2\end{array}$

Yrkesbakgrund* (antal personer)

Hälso- och sjukvård/Vård och omsorg

$\begin{array}{rr}8 & 7 \\ 3 & 2 \\ 1 / 1 & \\ 1 / 1 & \\ 2 & 1 \\ 1 & \\ 2 & 1 \\ 1 / 3 & 1 / 0\end{array}$

Annat/Ej angett

* Saknade data från de två första fokusgruppsintervjuerna (8 deltagare) 


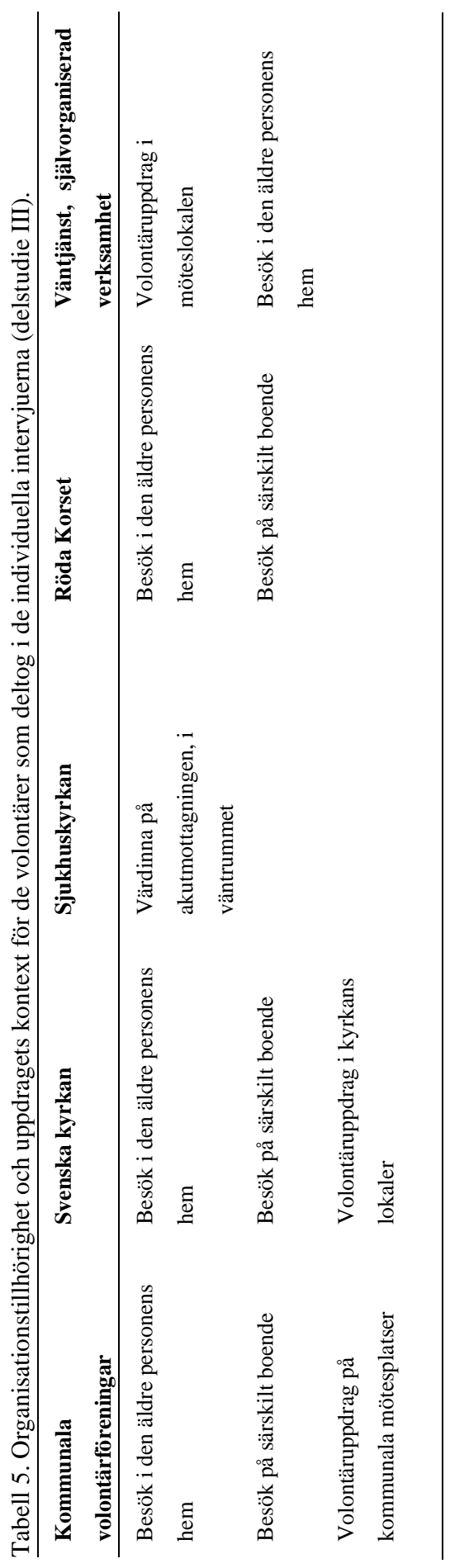


Tabell 6. Beskrivning av deltagarna, deras utbildning, erfarenhet och ansvar, samt enheten (delstudie IV).

$\boldsymbol{n}$

Ålder, år ${ }^{1}$

Range $27-74$

Medelvärde (SD)

$51(9,5)$

Kön ${ }^{2}$

Kvinna

Man

Annan

\section{Utbildning ${ }^{3}$}

Socionom/Social omsorg

Sjuksköterska

Arbetsterapeut

Fysioterapeut

Annan utbildning (t.ex. organisation och ledarskap,

beteendevetare personalvetare, sociologi)

Chefs/ledarskapsutbildning ${ }^{4}$

Ja

Nej

Erfarenhet som chef inom vård och omsorg, år ${ }^{2}$

$<1$

$1-5$

$6-10$

$>10$

Erfarenhet som chef på den aktuella enheten, år

$<1$

$1-5$

$6-10$

$>10$

Personalansvar för antal personer

$1-10$

$11-30$

$31-50$

51-70

$>70$

Enhetens vårdform ${ }^{3}$

Hemtjänst

Servicehus/Trygghetsboende

Gruppboende

Särskilt boende

Volontärer på enheten ${ }^{4}$

Ja

Nej

75

\footnotetext{
${ }^{1}$ Saknas $=8,{ }^{2}$ Saknas $=3,{ }^{3}$ Flervalsfråga, ${ }^{4}$ Saknas $=1$
} 


\section{Datainsamling}

Datainsamlingen till de fyra delstudierna har skett med olika datainsamlingsmetoder och i olika kombinationer.

\section{Delstudie I och II}

Datainsamlingen till delstudie I och II var gemensam och genomfördes med fokusgrupper (I) och i kombination med telefonintervjuer (II). Totalt genomfördes elva fokusgruppsintervjuer i hemvård, särskilt boende, sjukhus (medicinsk akutvård och ortopedi), palliativ vård, primärvård, samt ambulanssjukvård.

\section{Fokusgruppsintervjuer}

Fokusgrupper som datainsamlingsmetod valdes eftersom metoden möjliggör att olika perspektiv kan fångas, erfarenheter kan delas och tidigare erfarenheter kan komma fram genom att lyssna på andra med liknande erfarenheter (Krueger \& Casey, 2015). I fokusgruppsintervjuerna som genomfördes på deltagarnas arbetsplats deltog mellan 3 och 8 personer (median $=6$ ). Innan fokusgruppsintervjun startade lämnades på nytt information om studien, både muntligen och skriftligen och skriftligt samtycke inhämtades. Förutom frivilligheten betonades möjligheten att avstå och avbryta under tiden om så önskades. Fokusgruppen leddes av en moderator samt en bisittare. Moderatorn ledde fokusgruppsintervjun, ställde frågor utifrån intervjuguiden och såg till samtalet inte tappade fokus från ämnet samt att deltagarna fick komma till tals $\mathrm{i}$ den mån de önskade. Moderatorn och bisittaren hjälptes åt att ställa klargörande frågor om det behövdes, i övrigt var bisittarens roll att fånga upp trådar i samtalet som moderatorn eventuellt förbisåg.

Varje fokusgruppsintervju inleddes med en fråga om ensamhet i allmänhet och frågor om en djupare form av ensamhet i synnerhet, samt deltagarnas erfarenhet av att möta existentiell ensamhet hos äldre personer. Fokusgruppsintervjuerna inleddes på följande sätt:

Man kan vara ensam och det kan man vara på många olika sätt. Man kan känna sig ensam tillsammans med andra och man kan vilja vara ensam och kanske till och med längta efter att vara ensam. Hur tänker ni kring ensamhet och att vara ensam? 
När deltagarna hade diskuterat ensamhet $\mathrm{i}$ allmänhet ställdes nästa fråga som fungerade som en inledningsfråga till existentiell ensamhet och deltagarna uppmuntrades att dela sina erfarenheter i form av en berättelse:

Vi är särskilt intresserade av en djupare känsla av att vara ensam i livet, det som ibland kallas existentiell ensamhet, en känsla som kan komma och gå. Kan någon dra sig till minnes när den äldre/patienten/vårdtagaren gav uttryck för en djupare känsla av ensamhet? Det kan vara i form av en berättelse. Ni får gärna fundera en stund. Kanske väcks också erfarenheter till liv när ni hör varandra berätta?

Uppföljande frågor som handlade om vad det var som gjorde att de upptäckte existentiell ensamhet hos den äldre personen, om det fanns beredskap hos dem själva och/eller i arbetsgruppen, ställdes. Det ställdes även frågor om vilket stöd som fanns och/eller om det fanns behov av ytterligare stöd för personalen i att möta existentiell ensamhet. Innan intervjun avslutades sammanfattade bisittaren diskussionerna baserat på de anteckningar som förts under tiden. Dessutom bads deltagarna att lämna bakgrundsuppgifter såsom ålder, kön, profession, antal år i yrket samt anställningstid i den aktuella verksamheten. De tillfrågades också om det fanns intresse av att delta $\mathrm{i}$ en eventuellt uppföljande intervju. Två timmar var avsatt, där tid för introduktion, information om studien och inhämtade av samtycke ingick. Fokusgruppsintervjuerna (median $=1$ timme och $41 \mathrm{~min}$ ) ljudinspelades och transkriberades ordagrant.

\section{Telefonintervjuer}

I delstudie II kompletterades fokusgruppsintervjuerna med telefonintervjuer för att inhämta kontextuell information. Telefonintervjuerna gjordes med kontaktpersonen $\mathrm{i}$ respektive verksamhet. De kontaktades via e-post med en förfrågan om de kunde tänka sig att delta och fick i samband med det ta del av frågorna skriftligen. Information som efterfrågades handlade om verksamhetens inriktning och uppdrag, antal vårdplatser eller vårdtagare, vanligaste förekommande sjukdomar och problematik, åldersspann för patienter, personalsammansättning, antal anställda och vilka professioner som fanns $\mathrm{i}$ verksamheten. Vid intervjun efterfrågades om verksamheten hade en uttalad vårdfilosofi eller värdegrund och om personalen hade tillgång till handledning/omvårdnadshandledning samt om det förekom förbättringsoch utvecklingsarbeten. Dag och tid för telefonintervjun bestämdes av kontakt- 
personerna. Intervjuerna skedde i samtalsform och det som sades noterades och användes som underlag i analysen som komplement till fokusgruppsintervjuerna.

\section{Delstudie III}

Datainsamlingen genomfördes som en kombination av fokusgrupper och efterföljande individuella intervjuer med volontärer. Valet att kombinera dessa två former baserades på tanken att deltagare i fokusgruppsintervjuer utvecklar sina tankar när de diskuterar med andra och för att öka möjligheten att få en variation av erfarenheter (Kreuger \& Casey, 2015), medan individuella intervjuer i stället kan bidra med en djupare förståelse för ett givet fenomen (Ryan, Coughlan \& Cronin, 2009). Fokusgruppsintervjuerna fokuserade på volontärernas erfarenhet av att möta äldre personers ensamhet $\mathrm{i}$ allmänhet och existentiell ensamhet i synnerhet. Trots det kom diskussionerna i fokusgrupperna att främst handla om att möta ensamhet $\mathrm{i}$ allmänhet. Därför kompletterades datainsamlingen med individuella intervjuer för att få en djupare förståelse för volontärers upplevelser av att möta äldres existentiella ensamhet och vilka personliga motiv som låg bakom beslutet att bli volontär. De sex första fokusgruppsintervjuerna har även använts som underlag för att utforska volontärers uppfattningar om äldre personers existentiella ensamhet. Det resultatet är presenterat i en svensk rapport (Olsson, Rydsten \& Blomqvist, 2018).

\section{Fokusgruppsintervjuer}

I delstudie III genomfördes fokusgruppsintervjuerna enligt samma struktur som i delstudie I och II. De åtta fokusgruppsintervjuerna genomfördes i volontärorganisationens egna lokaler. Sju fokusgrupper hade mellan tre och fyra deltagare medan en fokusgrupp hade sju deltagare. Fokusgrupperna leddes av en moderator och bisittare. De två första fokusgruppsintervjuerna fungerade som pilotintervjuer då intervjuguiden testades. Eftersom inga förändringar gjordes inkluderades dessa två intervjuer i studien. Intervjuerna inleddes med en fråga om ensamhet i allmänhet och när deltagarna diskuterat ensamhet leddes diskussionen vidare till frågor om den djupare formen av ensamhet, existentiell ensamhet, samt deltagarnas erfarenhet av att möta äldre personers existentiella ensamhet. Deltagarna uppmuntrades att delge sina erfarenheter i form av en berättelse, det vill säga att ge konkreta bilder av egna möten med en äldre person och beskrivning av den aktuella situationen. Uppföljande frågor ställdes som handlade om vad det var som gjorde att de upptäckte existentiell ensamhet hos den äldre personen, om det hände att de samtalade om djup ensamhet och hur sådana samtal uppstod, om det fanns beredskap för att samtala om existentiella 
frågor hos dem själva och/eller bland de andra volontärerna. Det ställdes även frågor om vilket stöd som fanns och/eller om det fanns behov av ytterligare stöd. När intervjun avslutades ombads deltagarna att lämna bakgrundsuppgifter såsom ålder, kön, profession, antal år i yrket samt anställningstid i den aktuella verksamheten. Deltagarna tillfrågades också om det fanns intresse av att delta $i$ en uppföljande individuell intervju. Vid de två första fokusgruppsintervjuerna som fungerade som pilotintervjuer, inhämtades dock varken bakgrundsuppgifter eller intresseförfrågan om att delta i en uppföljande intervju. Två timmar var avsatta till fokusgruppsintervjuerna, en av fokusgrupperna varade i 69 minuter och de andra mellan 91 och 111 minuter. Alla intervjuer ljudinspelades och transkriberades ordagrant.

\section{Individuella intervjuer}

Den första individuella intervjun genomfördes som en pilotintervju för att testa intervjuguiden. Den inkluderades sedan i studien då endast mindre justeringar av intervjuguiden gjordes. Deltagarna fick bestämma tid och plats och intervjuerna genomfördes i volontärorganisationernas lokaler, i deltagarens hem eller på högskolan som var intervjuarens arbetsplats. Innan intervjun påbörjades fick deltagaren på nytt information om studiens syfte och ett skriftligt samtycke inhämtades. Intervjun, som utgick från en semistrukturerad intervjuguide (Brinkmann \& Kvale, 2015), inleddes med ingångsfrågor om existentiell ensamhet, och följdes av frågor om deltagarens tankar och erfarenheter om rollen som volontär. Det fanns frågor om hur deltagaren påverkades av att möta existentiell ensamhet hos de äldre som de träffade genom sitt volontäruppdrag samt om de som volontärer hade behov och tillgång till stöd om det behövdes. Uppföljningsfrågor som "Hur menar du?", "Kan du utveckla det?" och "Om jag uppfattar dig rätt, menar du att ..." ställdes och deltagarna gavs möjlighet att göra tillägg innan intervjun avslutades. De stödanteckningar som gjorts under intervjuns gång sammanfattades muntligt med möjlighet för den intervjuade volontären att bekräfta eller lägga till. De individuella intervjuerna varade mellan 45 och 97 minuter (median 72 minuter) och ljudinspelades och transkriberades ordagrant.

\section{Delstudie IV}

\section{Enkät}

Den enkät till enhetschefer som användes i delstudie IV designades speciellt för studien med inspiration av resultat från delstudie I-III och LONE-studien. För att skapa så valida frågor och svarsalternativ som möjligt diskuterades enkätfrågorna vid ett seminarium med andra forskare, och en testenkät skickades till projektgruppen 
inom LONE. Dessutom testades enkätfrågorna även av en person med tidigare erfarenhet som enhetschef med hjälp av think-aloud-metoden (Dillman m.fl., 2014). Frågorna och svarsalternativen justerades efter de kommentarer som framkom. Enkäten bestod av demografiska frågor om enheten och om chefen, och frågor om chefens syn på vårdpersonals och volontärers möjligheter och hinder, samt behov av stöd, i att möta äldre personers existentiella frågor. Enkäten var uppdelad i fem teman med frågor om enheten, existentiell ensamhet och existentiella frågor, vårdpersonal, volontärer och chefen. Den innehöll både fasta och öppna svarsalternativ. De fasta svarsalternativen bestod främst av $J a, N e j$ eller Vet inte eller flersvarsalternativ med möjlighet att lägga till egna svarsalternativ eller att skriva $i$ fritext utan ordbegränsning. När det gäller de öppna frågorna fanns möjlighet för respondenterna att svara med egna ord utan ordbegränsning (se Appendix). Alla frågorna redovisas dock inte $\mathrm{i}$ studien, och en fråga utgick på grund av ett tekniskt misstag där svarsalternativen presenterades i inkorrekt ordning.

Enkäten sändes ut via e-post under perioden 15 maj till 28 juni 2019. I epostmeddelandet fanns enkäten som en länk, men även en länk till en tvåminuters introduktionsfilm och ett informationsbrev. Brevet bestod av information om syftet med studien, att deltagandet var frivilligt, hur svaren skulle hanteras och förvaras enligt lag samt namn och kontaktuppgifter till forskarna. Utöver det första meddelandet skickades tre påminnelser, men då endast till de som inte besvarat enkäten.

Det webbaserade enkätverktyget, Evasys, användes för design, distribuering samt lagring och skydd av enkätsvar. Via Evasys förinställdes datum och klockslag för utskick. Evasys skickar även automatiskt ut påminnelser till de förinlagda epostadresser som ännu inte besvarat länken. Evasys är konstruerat så att man inte kan se vilka som besvarat länken eller koppla svaren till någon enskild chef eller enhet. När enkäten stängts fördes de insamlade svaren automatiskt över till Excel och SPSS. Svaren är avidentifierade och har endast ett nummer och placeras i den ordning de inkommit. 


\section{Analys}

\section{Delstudie I}

I delstudie I användes en deduktiv-induktiv ansats som växte fram under processens gång och baserades på så kallade reflekterande beslut, vilket kan vara en medveten strategi i kvalitativa studier (Polit \& Beck, 2012). I den första fasen, den deduktiva, användes en begreppsdriven strategi beskriven av Schreier (2012). Den baserades på ett teoretiskt ramverk av van Deurzen $(1998 ; 2012)$ som sedan följdes av induktiv fas i kombination med en tolkande ansats.

Analysen genomfördes i fyra steg. I det första steget lästes alla intervjuer för att få en överblick och en uppfattning om helheten. I materialet framträdde vårdpersonalens möten med existentiell ensamhet hos äldre personer och att existentiell ensamhet tog sig olika uttryck. Berättelser om personalens erfarenheter identifierades i relation till syftet och extraherades ur texten. I det andra steget strukturerades dessa berättelser enligt en analytisk mall inspirerad av filosofen och psykologen Emmy van Deurzens ramverk. Det inkluderar fyra dimensioner av livsvärlden: den fysiska världen, den sociala världen, den personliga världen samt den spirituella och andliga världen (van Deurzen, 1998; 2012) (tabell 7). Detta steg var begreppsdrivet (Schreier, 2012), och deduktivt, där en redan existerande teori, livsvärldsteorin, användes som en sorteringsram för berättelserna. I det tredje steget ställdes analytiska frågor till texten:

- Vilka kompetenser och förmågor använder personalen i mötet och i tolkningen av den äldre personens existentiella ensamhet?

- Vad har personalen för uppfattning och tolkning av den äldre personens existentiella ensamhet?

- Hur beskriver personalen att existentiell ensamhet uttrycker sig?

- Vad är personalens egna upplevelser av att möta den äldre personens existentiella ensamhet?

I det fjärde steget användes svaren på de analytiska frågorna som grund för att finna mönster och kategorier som beskriver de utmaningar som personalen ställdes inför $\mathrm{i}$ mötet med den äldre personens existentiella ensamhet. De övergripande kategorierna beskriver hinder i mötet. 
Tabell 7. Beskrivning av de fyra dimensionerna av van Deurzens teori om livsvärlden (van Deurzen, 1998; 2012).

\begin{tabular}{|c|c|}
\hline Benämning & Beskrivning \\
\hline Den fysiska världen & $\begin{array}{l}\text { Den mest grundläggande världen av de fyra, baserad på } \\
\text { antagandet att den mänskliga existensen är grundad i kroppen, och } \\
\text { inkluderar en relation till naturen, kroppen och sig själv på ett } \\
\text { fysiskt plan. }\end{array}$ \\
\hline Den sociala världen & $\begin{array}{l}\text { Den värld som handlar om den mänskliga existensen i relation till } \\
\text { andra. Det handlar om sociala interaktioner i vardagliga möten } \\
\text { och i relationer i den offentliga världen, och som är en oundviklig } \\
\text { del av livet. }\end{array}$ \\
\hline Den personliga världen & $\begin{array}{l}\text { En värld av närhet, till sig själv och i andra nära relationer. En } \\
\text { psykologisk dimension som inkluderar privata erfarenheter och } \\
\text { identitet. }\end{array}$ \\
\hline Den spirituella och andliga världen & $\begin{array}{l}\text { Den värld som skapar mening, om personens kontakt med } \\
\text { abstrakta värden i livet och ideala värden. Om spirituella och } \\
\text { andliga tankar, tro, övertygelser och önskningar om livet och } \\
\text { världen bortom den egna personen. }\end{array}$ \\
\hline
\end{tabular}

\section{Delstudie II}

Delstudie II genomfördes som en multiple case-studie med holistisk ansats (Stake, 1995; Merriam, 2016). Denna design lämpar sig väl när man vill utforska avgränsade och definierade system eller enheter, såsom olika kontexter. I denna studie bildade de fyra vårdkontexterna hemvård, särskilt boende, sjukhus samt palliativ vård var sitt case. De case som ska studeras består enligt Stake (1995) av så kallade multiple realities. Dessa ska beskrivas och bevaras trots att de innehåller motsägelser, vilket kan tolkas som att göra det komplexa begripligt utan att förenkla så att komplexiteten försvinner. Analysen genomfördes i två steg och med en induktiv analytisk ansats. I det första steget analyserades varje vårdkontext som ett case, så kallad within-case analysis. Vid genomläsning av texterna som delats in i fyra case kunde tre teman urskiljas, det som handlade om i) vårdpersonalens syn på vad som utlöst existentiell 
ensamhet, ii) omgivningen och platsen där vården gavs samt iii) relationer och vårdpersonalens roll i förhållande till äldre personers existentiella ensamhet. Utifrån dessa teman skapades en berättelse, som ett porträtt, av varje vårdkontext (Merriam, 2016). Det andra steget bestod av en så kallad cross-case analysis, en genomgående analys av alla case där de jämfördes och kontrasterades avseende skillnader och likheter mellan vårdkontexterna angående orsaken, platsen och vårdpersonalens roll (Creswell, 2007; Merriam, 2016).

\section{Delstudie III}

Intervjumaterialet i delstudie III analyserades med konventionell innehållsanalys enligt Hsieh och Shannon (2005) som beskriver tre varianter av innehållsanalys: konventionell, riktad och summativ. Den konventionella analysen valdes eftersom den rekommenderas när det inte finns några existerande teorier och modeller som kan användas. I denna studie, med fokus på volontärers erfarenheter av att möta äldre personer och existentiell ensamhet, bedömdes att det inte fanns någon teori eller modell att utgå från. I den konventionella analysen, som är induktiv, växer koder och kategorier succesivt fram under analysprocessen. För att få överblick och en känsla för materialet lästes i ett första steg fokusgruppsintervjuer och individuella intervjuer som en helhet. Därefter diskuterades intrycken av texten. Eftersom de individuella intervjuerna bedömdes innehålla mer personlig och djupgående information bestämdes att analysen skulle starta med dem. I enlighet med beskrivningen av metoden identifierandes meningsenheter som sedan kodades och sammanställdes i ett kodningsschema. Därefter analyserades fokusgruppsintervjuerna på samma sätt. När alla intervjuer var kodade sorterades de efter sitt innehåll i sammanlagt 13 så kallade "meningsfulla kluster" som växte fram under sorteringen. Under hela processen fanns en rörelse fram och tillbaka mellan texten, koderna, klustren och preliminära kategorier, innan de fyra kategoribenämningarna fastställdes. Det är enligt metoden även möjligt att identifiera hur kategorierna relaterar till varandra (Hsieh \& Shannon, 2005). På så sätt nåddes en övergripande förståelse av materialet.

\section{Delstudie IV}

Enkätsvaren i delstudie IV analyserades med deskriptiv statistik där svaren presenterades i siffror och procent. Valet att använda enbart deskriptiv statistik baserades på att svarsfrekvensen var 29 procent, och att materialet därför inte lämpade sig för gruppjämförelser. De öppna frågorna där många respondenter svarat i fritext 
sammanställdes. Svaren grupperades efter dess innehåll och presenterades i beskrivande form med illustrerande utdrag från texten. De frågor som genererade flest fritextsvar gällde de två frågorna om samtal om existentiella frågor mellan personal och de äldre, och i arbetsgruppen. Andra frågor med många fritextsvar handlade om ytterligare behov av stöd till personal samt vilka hinder det fanns i organisationen för att ge stöd (för en beskrivning av frågorna, se Appendix). 


\section{FÖRFÖRSTÅELSE}

Enligt min erfarenhet som sjuksköterska är existentiella frågor något som man som personal ställs inför, ofta i det enskilda mötet med patienter eller närstående. När det gäller äldre personer är min erfarenhet att dessa frågor finns hos många, mer eller mindre uttalat. Jag tror att mötet mellan människor i vårdande sammanhang är viktigt för båda parter och jag tror att det är möjligt att vara personlig i mötet med den äldre utan att tappa sin professionalitet. Som personal tar vi på oss en professionell roll i yrket, men det personliga finns med oss hela tiden. Det finns också något stärkande i ett äkta och ömsesidigt möte, samtidigt som det kan vara emotionellt krävande. I början av mitt avhandlingsarbete och i uppstarten av LONE-studien var min uppfattning att existentiell ensamhet hos sköra äldre $\mathrm{i}$ huvudsak handlade om döendet och döden, och livets sista tid. Det är en uppfattning som har ändrats under avhandlingsarbetet eftersom det för mig blev allt tydligare att det handlade om livet såväl som döendet och döden, men också den åldrande kroppen och att inte känna igen sig eller trivas i tillvaron.

Inledningsvis i LONE-studien och inför uppstart av mina delstudier har jag skrivit ner min förförståelse och i samband med det funderat över vad den består av. Inom ramen för LONE-studien har jag varit en del av projektgruppen där analyser och resultat från de olika studierna har presenterats och diskuterats. Inte minst när vi har träffat referensgruppen har det getts goda möjligheter att diskutera och stämma av resultat och få synpunkter från personer som har helt andra erfarenheter. Därigenom har jag fått möjlighet att fundera över min förförståelse.

Eftersom förförståelsen delvis är dold för en själv, har jag försökt att ifrågasätta och kontinuerligt reflektera över den. Inte minst i samband med analysarbetet i de kvalitativa studierna. Det är viktigt att vara medveten om sin förförståelse och för mig har ett sätt varit att diskutera resultatet med andra människor både inom och utanför forskargruppen och på så sätt ta del av andras uppfattningar, men också vara beredd att omvärdera mina egna. Tidigare erfarenhet kan guida en vidare i forskning och analysarbete, men också begränsa genom att man har förgivettagna föreställningar. Så, med andra ord, kan erfarenhet av vård vara både en risk och en tillgång. En risk 
för att man tolkar intryck och datamaterial med sin tidigare förförståelse, samtidigt som erfarenhet är något att relatera till när det gäller resultatens relevans och rimlighet. Min erfarenhet av volontärer och volontärorganisationer var ytterst begränsad innan studierna genomfördes och jag hade inte några direkta föreställningar mer än nyfikenhet om vad som motiverar till volontäruppdrag och om de kunde erbjuda något som inte vårdpersonalen kunde. Det fanns också en tanke om att det kunde vara utmanande och påfrestande att vara volontär och att man därför som volontär kunde behöva stöd. När det gäller enhetscheferna så var min föreställning att de hade en hög arbetsbelastning och därför inte gav det stöd som vårdpersonalen behövde. Även om förförståelsen har mindre betydelse i kvantitativa studier så är det inte oväsentligt. Enkätfrågorna diskuterades inom forskargruppen samt med andra forskare vid ett seminarium för att fler personer skulle bidra med sina perspektiv på frågornas utformning.

Det som har överraskat mig och gjort intryck på mig i samband med datainsamlingen är deltagarnas engagemang trots den osäkerhet många kände inför att möta de äldre och samtala om existentiell ensamhet med dem. Det förvånade mig att vårdpersonalen i flera av intervjuerna nämnde att de existentiella frågorna skulle överlåtas till någon annan, till exempel en präst eller kurator, trots att det var till personalen som de äldre vände sig. 


\section{ETISKA ASPEKTER}

I denna avhandling har de fyra etiska principerna autonomiprincipen, att inte skada, att göra gott och rättviseprincipen (Beauchamp \& Childress, 2013) samt Helsingforsdeklarationens etiska principer (WMA, 2013) varit vägledande. Etikprövning för LONE-studien som helhet är genomförd i enlighet med lag om etikprövning (SFS 2003:460) och delstudierna I och II är godkända av Etikprövningsnämnden i Lund, diarienummer 2014/652. En kompletterande etikprövning för delstudie III gjordes med diarienummer 2018/715, Etikprövningsnämnden i Lund. Delstudie IV bedömdes inte omfattas av Etikprövningslagen eftersom de frågor som ingick i enkäten inte var av personlig karaktär eller gällde enhetschefernas egen hälsa. Några andra känsliga personuppgifter som innefattas av Etikprövningslagen efterfrågades inte heller. Vi som forskare kunde inte härleda de inkomna enkätsvaren till enskilda personer.

\section{Autonomiprincipen}

Beauchamp och Childress (2013) definierar autonomiprincipen som vägledande för beslut i hälso- och sjukvård och forskning och innefattar förutom en respektfull hållning även ett respektfullt agerande. För att respektera människors självbestämmande grundade sig samtliga studier på en informerad samtyckesprocess (Kjellström, 2012). Information om projektet till de olika verksamheterna gavs $i$ samband med arbetsplatsträffar (I, II), i de flesta fall av personer i projektgruppen. Utöver den muntliga informationen lämnades även skriftlig information för att alla skulle få ta del av samma information och ges möjlighet till betänketid. För att undvika påverkan från forskarna anmälde sig de som var intresserade att delta i en fokusgruppsintervju direkt till en utsedd kontaktperson i respektive verksamhet. Dessa namn förmedlades sedan vidare till projektgruppen. Innan fokusgruppsintervjuerna påbörjades, vilket i de flesta fall skedde inom 4-6 veckor, upprepades informationen och möjlighet att ställa frågor gavs. För att ytterligare stärka deltagarnas självbestämmande hade kontaktpersonen i verksamheten en checklista att följa med information om allmänna forskningsetiska principer, exempelvis frivillighet och att det inte var tillåtet med påtryckningar vare sig från 
forskarna eller någon annan person. Trots det finns inga garantier och påtryckningar kan ske subtilt. Deltagande i forskning baseras på frivillighet och detta poängterades igen i samband med alla elva fokusgruppstillfällena där möjlighet fanns att avstå från deltagande utan att behöva ange orsak. När det gäller ambulansverksamheten som deltog i delstudie I rekryterades deltagarna på ett annorlunda sätt eftersom verksamheten inte ingick i LONE-studien. I stället togs personliga kontakter med presumtiva deltagare. Fokusgruppsintervjun genomfördes på ambulanspersonalens arbetsplats under dagtid.

Datainsamlingen till studien om volontärer (III), sträckte sig över en längre tid, då de första fokusgruppsintervjuerna genomfördes hösten 2014 och resterande 2017-2018. Det innebar att tiden mellan att presumtiva deltagare kontaktades och tillfrågades om de ville delta i efterföljande individuella intervjuer varierade, mellan ett par veckor till 1,5 år och i ett fall 4 år. Till en del av personerna fanns postadresser, till andra fanns det e-postadresser och till ytterligare ett par fanns det enbart telefonnummer som kontaktuppgifter. I första hand skickade jag brev eller e-post med informationsbrev där jag bad de presumtiva deltagarna att kontakta mig om det fortfarande fanns ett intresse av att vara med. Övriga kontaktade jag per telefon. Eftersom jag inte genomförde alla fokusgruppsintervjuerna hade jag inte träffat dem alla tidigare. Det medförde att jag inför varje telefonsamtal medvetet strävade efter att vara koncentrerad och lyhörd för eventuell tvekan hos de presumtiva deltagarna. En del av de uppringda volontärerna mindes studien direkt och var positiva till att delta, medan andra var mer på sin vakt. I de senare fallen var jag noggrann med att påtala att det var frivilligt och hur jag hade fått deras kontaktuppgifter, i syfte att inte orsaka obehag. Det kan kännas överrumplande att bli kontaktad efter så lång tid, inte minst av en person man inte tidigare träffat. Ett informationsbrev skickades sedan hem med posten utom till dem som redan vid telefonsamtalet tackade nej. För att värna om autonomiprincipen kom vi överens om att de skulle kontakta mig om det fanns intresse, för att inte någon skulle känna sig pressad att delta eller behöva tacka nej. Om de sedan inte hörde av sig togs det som ett nej och ingen mer kontakt togs från min sida.

\section{Principerna att inte skada och göra gott}

Principen att inte skada (Beauchamp \& Childress, 2013) är viktig inom forskning. Skada eller lidande ska undvikas eller minimeras och får inte överstiga nyttan av forskningen. För att inte störa verksamheterna i onödan genomfördes datainsamlingen 
under en koncentrerad tidsperiod i respektive verksamhet och till enbart ett fåtal verksamheter i taget. Datainsamlingen för delstudie I och II, det vill säga fokusgrupper med vårdpersonal, genomfördes under 2015 och 2016 och under samma period som andra personer i projektgruppen genomförde individuella intervjuer med äldre personer och deras närstående i respektive verksamhet.

Flera olika professioner deltog i fokusgrupperna (I, II). I många organisationer finns det hierarkier där vissa grupper eller professioner har mer inflytande än andra och det kan i någon av fokusgrupperna ha haft inverkan, åtminstone inledningsvis. Ofta vill människor framstå $\mathrm{i}$ god dager och att ge en bild av sig som motsvararar den egna självbilden. Detta beskrivs som framträdandestrategier enligt sociologerna Burkes och Stets (refererad i Nyström, 2012). Det kan handla om att försvara sin självbild både utifrån profession och/eller sin plats och position på arbetsplatsen. Det kan också uppstå en krock mellan olika kunskapssyner och risken ökar ju mer heterogen en grupp är. I merparten av fokusgrupperna var sjuksköterskor och undersköterskor i majoritet, medan det i vissa fokusgrupper fanns någon som var ensam om att representera sin profession. Det skulle potentiellt kunna orsaka en känsla av att vara utsatt om man blev ensam om att försvara ett sätt att tänka eller göra. För att skapa en tillåtande atmosfär, och inte skada, inleddes varje fokusgruppsintervju med att förklara upplägget och att det inte fanns rätta eller felaktiga svar utan det som efterfrågades var deras erfarenheter av existentiell ensamhet hos äldre personer.

Datamaterial har förvarats inlåst och kommer att förvaras inlåst så att ingen obehörig får tillgång till materialet så länge det ska arkiveras (SFS 1990:782). Ljudfiler förvaras separerade från information som går att koppla till enskilda personer. Högskolan Kristianstad har ett övergripande ansvar för forskningsdata och följer riktlinjerna enligt dataskyddsförordningen, GDPR (Datainspektionen). Fokusgruppsintervjuerna genomfördes under arbetstid och på personalens arbetsplats, vilket medför att kollegor och chefer kan ha kännedom om vilka som deltog. Vid presentation av resultat $\mathrm{i}$ vetenskapliga publikationer och vid konferenser kommer särskild vikt att läggas vid att enskilda personer eller verksamheter inte ska kännas igen eller identifieras för att inte orsaka skada genom att någon känner sig utpekad. Information av konfidentiell och privat karaktär som framkommit i samband med intervjuer ges i förtroende och tillit (Beauchamp \& Childress, 2013). Att missbruka konfidentialitet och förtroende som forskare är oetiskt och kan förutom lidande och obehag skapa misstro mot forskning i allmänhet och framtida deltagande i studier i synnerhet. 
Personal inom olika professioner som möter sköra äldre personer i olika vårdsammanhang har ofta en erfarenhetskunskap, ibland som tyst kunskap, som är värdefull att fånga. Under strukturerade former kan möjligheten att få samtala och reflektera över möten med äldre personer upplevas meningsfullt. Detta gäller även situationer som kan upplevas svåra. Det skulle kunna ses som att göra gott och vara till gagn för deltagarna i fokusgruppen. Trots det är det inte uteslutet att samtal om existentiell ensamhet hos de äldre personer som de mött i sitt arbete kan väcka obehag eller samvetsstress.

\section{Rättviseprincipen}

Med hänvisning till rättviseprincipen (Beauchamp \& Childress, 2013), som handlar om rätt till lika behandling med hänsynstagande till individers olikheter, bör olika röster komma till tals i forskning. I denna avhandling ingick förutom vårdpersonal från olika kontexter även volontärer från olika organisationer och enhetschefer inom vård och omsorg. Genom att belysa ett fenomen ur olika perspektiv kan värdefull kunskap vinnas. Volontärer kan även ses som samhällsmedborgare och ge ett annat perspektiv än personal inom hälso- och sjukvård och vård och omsorg. När det gällde urvalet av enhetschefer så skedde det slumpvis utan att ta hänsyn till några specifika egenskaper hos cheferna, verksamheterna eller var i landet de arbetade. Utifrån rättviseprincipen innebar det slumpvisa urvalet därför att alla hade lika stor möjlighet att ingå i enkätstudien. 


\section{RESULTAT}

\section{Vårdpersonalens erfarenheter av existentiell ensamhet}

Vårdpersonalens berättelser om existentiell ensamhet handlade om vardagliga situationer i vården. De uppfattade att existentiell ensamhet kunde ta sig olika uttryck hos sköra äldre personer i samband med åldrande, sjukdom och livets slut. Vårdpersonalen uppfattade att det var en känsla som inte var beständig, även om det hos vissa äldre personer var en återkommande känsla som kunde vara kopplad till specifika situationer. I berättelserna framkom de svårigheter som personalen upplevde i att möta existentiell ensamhet. Det fanns personal som lyckades ta sig förbi hindren och sin osäkerhet, men inte alla. Resultatet presenteras först i form av egenskaper som är betydelsefulla för att tolka och förstå, därefter olika hinder som personalen upplevde (I). Resultatet presenteras även i relation till skillnader mellan vårdkontexter i personalens uppfattningar om orsaker till existentiell ensamhet (I, II).

\section{Betydelsefulla egenskaper för att tolka och förstå}

I vårdpersonalens berättelser framkommer flera egenskaper och förmågor som är betydelsefulla för att tolka och förstå existentiell ensamhet. Oavsett de hinder som upplevdes i mötet fanns det berättelser där det framkom exempel på hur personalen använde egenskaper och förmågor för att förstå och möta existentiell ensamhet. Det handlade om egenskaper som empati, medkänsla, mod, nyfikenhet och en öppenhet inför en annan persons situation. Förmågor som var värdefulla i mötet handlade om att kunna lyssna, reflektera och byta perspektiv för att sätta sig in i den andres livsvärld, utan att värdera eller döma. Att ha kännedom om den äldres liv, både som det har varit och som det är nu, var betydelsefullt. Att ha kunskap om den historia och kultur som har präglat de äldre, och hur samhället har förändrats, var viktigt för att tolka och förstå äldre personers situation generellt, och för att kunna möta existentiell ensamhet och existentiella frågor i synnerhet. De tillfällen när personalen fick förtroendet och möjligheten att dela en annan persons innersta tankar var speciella. Dessa möten stannade kvar i minnet hos personalen, ofta under många år (I). 


\section{Vårdpersonalens beskrivning av hinder i mötet}

\section{Osäkerhet när den sköra kroppen begränsar}

Vårdpersonalen upplevde osäkerhet när den äldres sköra kropp begränsade kommunikationen och interaktionen med andra. Det kunde handla om kognitiv svikt som vid demenssjukdom, nedsatt hörsel och syn, eller svår smärta. De tolkade upplevelsen av existentiell ensamhet som att vara ledsen, övergiven, känslor av ångest, rädsla, att vara sårbar och isolerad. När kroppen var en begränsning för att uttrycka sina upplevelser tolkade personalen existentiell ensamhet som en oförmåga att fly från situationen, att vara dömd att se på världen och vad som sker utan att vara en del av den, eller att leva i en värld för sig själv. När personalen inte kunde tolka, förstå och hjälpa kände de sig osäkra, otillräckliga och maktlösa. I vissa fall kände de också medkänsla och vemod. Känsla av otillräcklighet väcktes av att inte kunna nå eller förstå utan i stället behöva gissa sig till vad den äldre behövde (I).

\section{Motstånd när behoven upplevs omättliga}

Vårdpersonalen upplevde ett motstånd hos sig själva när den äldres behov av social kontakt upplevdes som omättliga och svåra att tillgodose. De uppfattade att den äldres längtan efter kontakt tog sig olika uttryck som hemlängtan, hjälpsökande och ångest, men även ilska, rädsla inför döden eller inför att behöva dö ensam. Den äldres försök till att skapa mänsklig kontakt och längtan efter närhet uppfattades som ett uttryck för existentiell ensamhet, vilket kopplades till en känsla av att vara osynlig och bortglömd av omvärlden. När personalen inte kunde tillgodose den äldres krav och önskemål väckte det en känsla av försvar hos dem själva som gjorde att de ville distansera sig. Personalen kände sig frustrerade och otillräckliga när de inte kunde tillgodose den äldres behov, eller fylla det inre tomrummet, oavsett vad och hur mycket de än gjorde (I).

\section{Osäkerhet $i$ hur man ska ta sig igenom den personliga skyddsmuren}

Vårdpersonalen upplevde osäkerhet när de äldre upplevdes avskärma sig och bygga upp en personlig skyddsmur mot nära relationer. Det uppfattades som en ovillighet att dela sin privata sfär, vilket utgjorde ett hinder i relationen. Dessa äldre uppfattades vara personer som alltid levt enligt egna regler och inte litat på andra än sig själva. Uttryck som ångest, bitterhet och ilska kopplades till existentiell ensamhet som en reaktion på personens oförmåga att upprätthålla sina livsregler och sitt oberoende. Personalen uppfattade att det fanns en ambivalens mot att släppa kontrollen och släppa in andra. Personalen kände sig osäkra på vilka de skulle låta vara och vilka de skulle försöka nå. Med intuition och känsla i situationen beskrev personalen hur de lyckats 
hitta en glipa och en väg in, förbi den osynliga skyddsmuren, utan att göra intrång $\mathrm{i}$ den personliga integriteten. Möten med existentiell ensamhet kännetecknades här av personalens engagemang och vilja att nå den äldre och känsla av ansvar för att stödja den äldre. Om de inte blev insläppta kände de att de inte gjort tillräckligt (I).

\section{Rädsla och svårigheter att möta existentiella frågor}

Vårdpersonalen upplevde rädsla och svårigheter inför att möta och samtala om existentiella frågor, både hos sig själva och hos de äldre som de mötte. När personalen ställdes inför den äldres existentiella frågor om livet, kunde de känna in den äldres ångest och vånda, meningslöshet och besvikelse. De känslorna kopplades till rotlöshet, övergivenhet och hopplöshet som gällde tiden som varit, men också om meningen med livet i nuet och inför framtiden. Grubblerier om skuld och ånger, men också de äldres tankar inför döden, återfanns i personalens berättelser. Tankar om brustna relationer och val som gjorts tidigare i livet, men också uttryck för att vara värdelös och att inte längre vara till nytta för någon, att känna sig som en främling $\mathrm{i}$ samhället, beskrevs som tecken på existentiell ensamhet. Personalen beskrev att det fanns äldre som hade svårighet att $\mathrm{i}$ ord beskriva sina känslor och tankar om existentiella frågor eller att känna sig ensam på djupet. Det kunde ta sig uttryck i att personen fokuserade på sin kropp, tecken på svaghet och försämring, och genom att de sökte kontakt med personal. Trots att personalen kunde känna igen tecknen på existentiella grubblerier, hindrades de av sin egen rädsla och svårigheter att samtala om existentiella frågor. Att ställas inför existentiell ensamhet och existentiella frågor väckte funderingar hos personalen själva. Att möta och samtala om existentiella frågor förutsätter, enligt personalen, både självkännedom och mod. En annan reflektion var vikten av att prioritera existentiella samtal och att prata om döden och döendet innan det är försent (I). (Se figur 1.) 


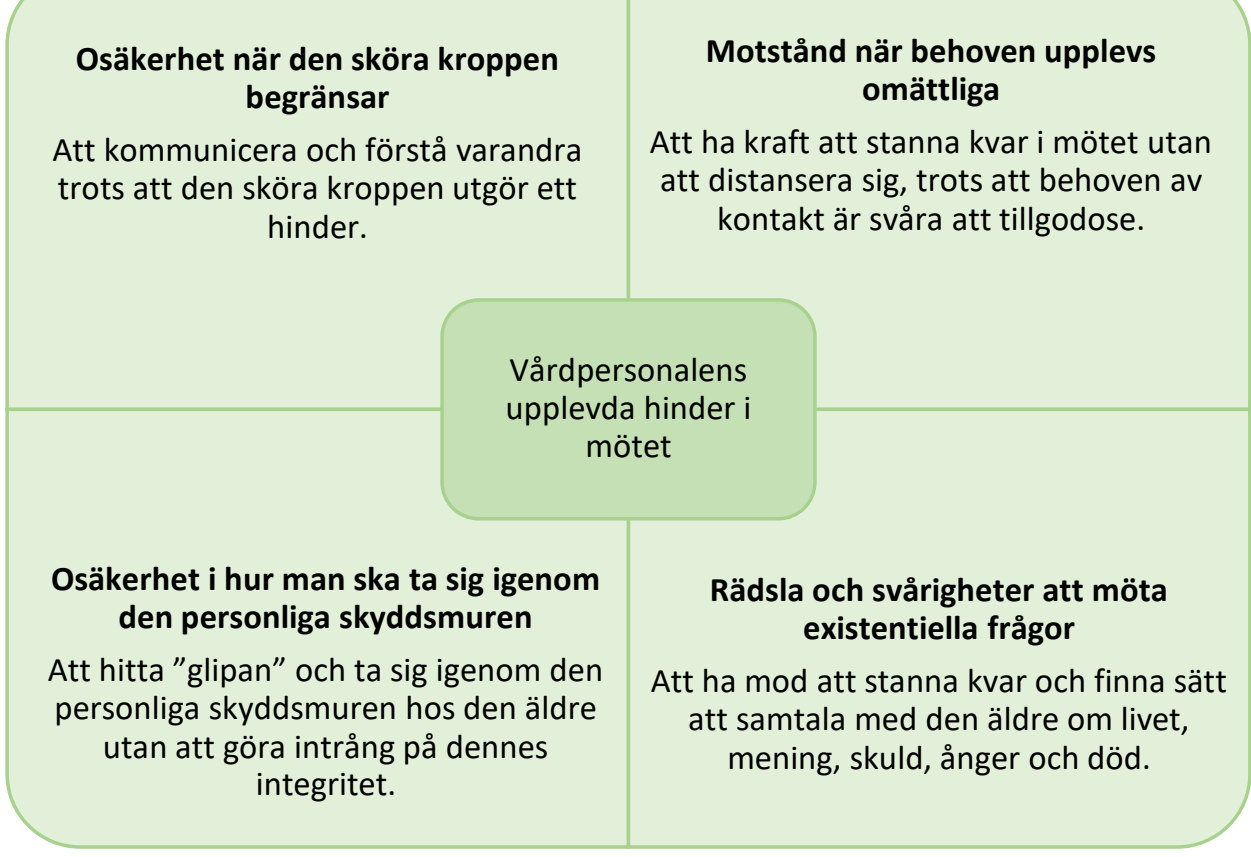

Figur 1. Vårdpersonalens beskrivning av hinder i mötet.

\section{Vårdkontextens betydelse för existentiell ensamhet}

Vårdplatsen hade betydelse för existentiell ensamhet och för vårdpersonalens förutsättningar att möta sköra äldre personers behov. Att ge vård i hemmet, som i hemvård och inom palliativ vård, respektive på institution, som på särskilt boende, sjukhus och inom palliativa slutenvårdavdelningar, innebar olika förutsättningar (II).

\section{Hemvård}

I hemvård beskrev personalen att existentiell ensamhet handlade om att den äldre personen saknade sitt tidigare liv, att inte längre känna sig behövd eller att inte längre kunna leva självständigt och ha en meningsfull tillvaro i sitt eget hem. Existentiell ensamhet uppfattades också kunna uppstå när den äldre personen inte längre hade någon som kunde dela och relatera till minnen, tankar, värderingar och betydelsefulla livshändelser. Kontinuitet och att känna den äldre underlättade existentiella samtal. Trots att personalen kopplade existentiell ensamhet till döden var det sällan något man pratade med de äldre om (II). 


\section{Särskilt boende}

På särskilt boende beskrev personalen att existentiell ensamhet handlade om relationer och förlust av betydelsefulla personer i sitt liv, eller om konflikter och dåliga relationer till sina barn och sin familj. Existentiell ensamhet relaterades till känslor av främlingskap inför sig själv, sin kropp och i relation till andra personer på boendet. De beskrev vikten av att bygga relationer och menade att beröring var relationsskapande och ett sätt att minska existentiell ensamhet. En del personal undvek existentiella samtal eftersom de kände sig obekväma medan andra ansåg att det var viktigt. Personalen på särskilt boende kopplade existentiell ensamhet till att närma sig sin egen död, men det förekom sällan existentiella samtal om exempelvis tankar kring döden eller vad som sker efteråt. Även de som hade erfarenhet av samtal om existentiella frågor med de äldre undvek eller bytte ofta ämne när döende och död kom på tal (II).

\section{Sjukhus}

På sjukhus hade personalen inte reflekterat över vad existentiell ensamhet kunde bero på, inte heller samtalade som regel personalen med de äldre personerna om deras existentiella funderingar. Personalen uppfattade att existentiell ensamhet handlade om livets slut, något som var svårt att sätta ord på och därmed svårt att samtala om. Dock fanns det personal som önskade att samtal om existentiella frågor varit en naturlig del av vården på sjukhus. Personal på sjukhus såg sig inte som ett stöd eller samtalspartner till den äldre om existentiella frågor. Att vara lyhörd för existentiella frågor och existentiella aspekter av döden ansågs i stället vara en personlig egenskap och förmåga, och ensamhet $\mathrm{i}$ allmänhet och existentiell ensamhet var inget som personalen på sjukhus pratade om med den äldre eller i arbetsgruppen (II).

\section{Palliativ vård}

Inom palliativ vård beskrev personalen att existentiell ensamhet $\mathrm{i}$ huvudsak handlade om döden och att det var en känsla som kom inifrån och som man inte kunde fly ifrån. Existentiell ensamhet uppfattades också handla om brist på mänsklig och kroppslig kontakt, en känsla att vara övergiven. Det tog sig uttryck i att den äldre ville hålla handen och sökte efter kontakt genom att vilja hålla handen och känna närhet av en annan människas. Personal inom palliativ vård ansåg att det var en viktig del av deras roll att skapa meningsfulla relationer med patienterna och att fånga upp existentiella funderingar. Samtidigt fanns det personal som uttryckte att existentiella frågor tillhörde den privata sfären, inklusive sin egen och därför undvek existentiella samtal. 
Äldre personer uppfattades ha lättare för att dela med sig av sina livsberättelser än yngre personer. Vid sjukdom och när man känner sig svag ansågs berättandet ha särskilt stor betydelse. Det sågs som ett sätt att få syn på sig själv igen, i en tid av förändring och förlust av förmågor och när insikten når en att det inte längre finns någon återvändo. Genom att dela tankar och känslor med en annan människa kunde patientens existentiella ensamhet skingras, åtminstone för en stund. Personalen beskrev hur existentiella samtal kunde uppstå i samband med omvårdnadssituationer, vid beröring och fysisk kontakt, och i tystnad utan krav. Att sänka tempot, vänta in och låta den äldre personen prioritera vad som skulle göras, i stället för att låta rutiner styra, var betydelsefullt (II).

\section{Skillnader och likheter mellan olika vårdkontexter}

Det fanns både skillnader och likheter när det gällde intentionen med vården, där det i hemvård och särskilt boende var att skapa en meningsfull vardag, medan målet på sjukhus var att bota, med fokus på utskrivning. I palliativ vård var syftet att ge en god vård i livets slut. Det fanns även skillnader och likheter, men också motsägelser när det gällde platsens betydelse och vårdkontextens inverkan på existentiell ensamhet. Hemmet som plats bidrog till att bevara den äldre personens identitet. Trots att personalen beskrev att hemmet i huvudsak underlättade att bibehålla den äldres självbild och identitet, så beskrev personal i hemvård att hemmet också kunde vara isolerande för den äldre, och personal i palliativ vård uttryckte att hemmet som plats kunde förändras i takt med att den äldre blev alltmer beroende av andra människor. Platsen som trygghet beskrevs av personal på sjukhus, palliativ vårdavdelning och på särskilt boende, men det fanns motsägelser. Exempelvis kunde sjukhusavdelningen som miljö och plats hindra existentiella samtal eftersom det saknades avskilda platser. En palliativ vårdavdelning kunde, trots trygghetsskapande atmosfär, vara en påminnelse om att personen aldrig mer skulle kunna komma hem. På särskilt boende kunde den äldre personens rum ses som en fristad, medan gemenskapsutrymmena som matsal och allrum i stället kunde bidra till att den äldre kände sig som en främling bland de andra (II).

Resultatet visar att det finns skillnader mellan olika vårdkontexter när det gäller vårdpersonalens uppfattningar om existentiell ensamhet och varför den uppkommer. I alla fyra vårdkontexterna hemvård, särskilt boende, sjukhus och palliativ vård relaterades existentiell ensamhet till döden, om än i varierande grad medan i hemvård och på särskilt boende var uppfattningen att existentiell ensamhet i huvudsak handlade 
om livet. Regelbunden handledning och organiserade möten för reflektion erbjöds till vårdpersonalen i palliativ vård som en integrerad del av verksamheten, vilket saknades både i hemvård och på särskilt boende. På sjukhus fanns inget formaliserat stöd för existentiella frågor och personalen erbjöds inte heller handledning (II).

\section{Volontärers erfarenheter av att möta olika ensamheter}

Den övergripande förståelsen av att vara volontär handlade om att vara en medmänniska och lindra ensamhet hos andra och sig själv (figur 2). Volontärers erfarenheter av äldre personers ensamhet $\mathrm{i}$ allmänhet och existentiell ensamhet $\mathrm{i}$ synnerhet, har både likheter och skillnader med vårdpersonalens. Volontärerna träffade äldre personer i olika kontexter, det vill säga i den äldre personens hem, på särskilt boende, på sjukhus och på olika mötesplatser. Därför träffade de också äldre personer som ännu inte var $\mathrm{i}$ något större behov av vård och omsorg. Volontäruppdragen såg olika ut och kunde bestå av alltifrån tillfälliga kontakter till långvariga relationer som varade över flera år (III). 


\section{Att vara en medmänniska och lindra ensamhet hos andra och sig själv}

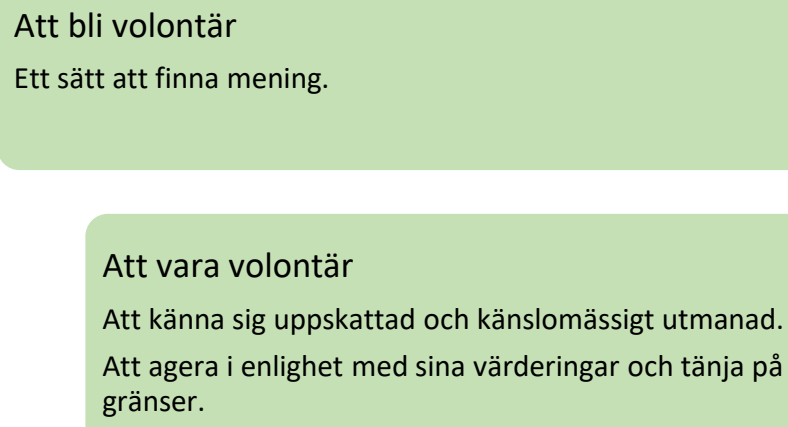

Figur 2. Att bli och vara volontär, att möta äldre personers ensamhet i allmänhet och existentiell ensamhet i synnerhet.

\section{Att bli volontär - finna mening och lindra ensamhet}

Volontärerna hade olika anledningar till att de hade blivit volontärer: att göra gott $\mathrm{i}$ allmänhet och göra något meningsfullt. För flera av dem var volontäruppdraget ett sätt att träffa äldre personer för att man ville det och såg att det fanns behov. Flera hade själva vårdat eller sett sina egna föräldrar i en vårdsituation och ville därför bidra till att göra den bättre för någon annan. En annan anledning och ett annat motiv var att ge tillbaka något till samhället, som en medborgerlig plikt. Däremot fanns det olika uppfattningar om vilken form av relationer man ville ha inom ramen för volontäruppdraget, och där nära relationer som varade över tid inte var syftet för alla. För några var i stället volontäruppdraget ett bidrag till den verksamhet man utför sitt uppdrag i, och de personer man möter vid det tillfället. Andra valde volontäruppdrag där man som volontär träffar några och kanske endast en äldre person där en djupare och mer personlig relation kunde skapas. För många innebar volontäruppdraget en tillgång till ett nytt sammanhang inom ramen för volontärorganisationen, vilket kunde 
vara mer eller mindre formellt. Dessa sociala aktiviteter var värdefulla och där skapades vänskapsrelationer som var betydelsefulla. Kontakten innebar att man fick vänner utanför själva uppdraget. Att vara volontär och göra gott, finna mening, ha relationer till äldre personer och andra volontärer lindrade inte bara den äldre personens ensamhet utan även den egna ensamheten (III).

\section{Att vara volontär - förutsättningar och utmaningar}

Förutsättningarna för volontäruppdraget varierade beroende på var volontären utförde sitt uppdrag och i vilken organisation man tillhörde. Det fanns gränser för vad man får göra, vad man bör och inte bör göra, och vad man faktiskt gör. Samtidigt berättade vissa volontärer att man tänjde på sitt uppdrag i vissa situationer och agerade enligt sina värderingar. Andra var mer osäkra på uppdragets begräsningar eftersom det kunde uppstå situationer som inte gick att förutse och där man som medmänniska kände ett ansvar inför den andre. Volontäruppdraget innebar för en del att känna sig som en outsider och inte vara inkluderad i den verksamhet där uppdraget utfördes. I vissa fall kände de sig som någon som togs för given, vilket gjorde dem besvikna. Andra volontärer beskrev hur de kände sig som en del av verksamheten trots det frivilliga uppdraget och beskrev det som att vara en kugge i ett hjul. Volontäruppdraget, och att ta del av den äldre personens existentiella funderingar, förutsatte självkännedom och att för egen del vara klar över sina värderingar kring frågor om livet och döden. Uppdraget innehöll både existentiella och känslomässiga utmaningar. Det fanns känslor av frustration, maktlöshet och otillräcklighet. Det kunde handla om situationer när man som volontär ville göra mer, nå fram till den äldre, eller när man som volontär såg situationer i vården där personal eller närstående handlade på ett sätt som inte stämde överens med de egna värderingarna. Vid sådana tillfällen hade de flesta någon i volontärorganisationen eller i sin närhet, vän eller familj, att samtala med. Andra valde att ta en stund för sig själva, fundera och samla ihop sig (III).

\section{Att vara lyhörd för behov av närhet och distans}

Volontärerna hade olika förhållningssätt till de äldre som de hade uppdrag för. Vissa beskrev betydelsen av närhet, eller att kunna växla mellan närhet och distans beroende på situationen. Andra såg betydelsen av distans för att själva må bra. Egna erfarenheter av livet, förluster och ensamhet påverkade i sin tur deras syn på existentiell ensamhet. På så sätt hade man en gemensam erfarenhet och kunde dela den som medmänniska, och förmedla "det har varit likadant för mig". Volontärer beskrev existentiell ensamhet hos de äldre som att vara ensam på insidan, och ha en känsla av tomhet och 
att inte längre vara en del av gemenskapen med andra. Existentiell ensamhet kunde också vara kopplad till att man inte ville vara en börda för andra eller att inte ha någon att anförtro sig åt längre. Existentiell ensamhet var kopplad till sorg och förlust, att inte längre kunna kommunicera och som att "vara i en bubbla". Att berätta om sina existentiella behov och lidande i existentiella samtal var ingen självklarhet. Volontärerna menade att det kunde vara svårt för de äldre att finna ord och att de därför avstod från att berätta. Däremot var inte ord det enda verktyget, utan vikten av att vara bekväm med tystnad och att kunna anpassa sig till ett långsammare tempo beskrevs som viktiga förmågor som volontär till äldre personer (III).

Tid var avgörande för att skapa tillit hos den äldre personen, samtidigt som ömsesidighet i relationen var grundläggande. Som volontär hade man en annan relation till tid än exempelvis vårdpersonal som ofta hade någon annan som väntade på deras uppmärksamhet. Existentiella samtal kunde inte planeras utan de uppstod under rätt förutsättningar och på den äldre personens villkor. Därför var det viktigt att känna in, vara öppensinnad och urskilja vilka som hade behov av och vilka som inte ville fördjupa samtalet i existentiell riktning. Det var inte alla volontärer som samtalade om sådana frågor. Vissa undvek den typen av samtal för att de inte kände sig kompetenta och trygga. Andra försökte avleda samtal om ensamhet och inte ge det för mycket uppmärksamhet. Tanken var att samtal med en mer positiv grundton i stället kunde fånga glädjen i stunden och på så sätt lindra ensamhet. Det fanns volontärer som använde sig av ett sådant förhållningssätt för att möta äldre personers existentiella behov av gemenskap och finna mening och glädje i vardagen. I relationen med den äldre personen framhölls att "bara vara" som mest betydelsefullt, samtidigt som att "göra" saker tillsammans nämndes av flera volontärer. Det kunde handla om praktiska saker som man hjälpte den äldre med i bostaden eller att man planerade och gjorde någon gemensam aktivitet tillsammans. Vid dessa tillfällen fanns det även utrymme och öppningar för existentiella samtal enligt de volontärer som kände sig bekväma att föra sådana samtal (III).

\section{Enhetschefers syn på existentiella frågor}

Enhetscheferna inom vård och omsorg uppfattade att äldre personer gav uttryck för existentiella frågor och existentiella behov som de behöver samtala om med andra människor. Resultatet visade att 88 procent av enhetscheferna uppfattade att äldre personer ibland eller ofta gav uttryck för existentiell ensamhet. Enhetscheferna 
uppgav att kognitiv svikt ( 85 procent) och afasi (59 procent) utgjorde hinder för existentiella samtal. De äldres osäkerhet ( 66 procent) och ovilja/olust (59 procent) var andra hinder. När de gällde enhetschefernas uppfattning om hinder hos personalen angav de personalens osäkerhet ( 88 procent) liksom ovilja/olust (43 procent) som hinder för existentiella samtal (IV).

Enhetscheferna beskrev att existentiella samtal mellan de äldre och personalen handlade om hur den äldre uppfattar livet nu, det förflutna och deras funderingar samt grubblerier inför framtiden och den förestående döden. Enhetscheferna beskrev i de öppna svaren att de äldre pratade med personalen om att de inte längre kände mening med livet och samtalen rymde känslor som rädslor, ensamhet, förluster och främlingskap. Det fanns också behov hos de äldre att prata om den sköra kroppen och att känna sig begränsad, att inte kunna gå och röra sig som tidigare. Enligt enhetscheferna fanns det äldre som i samtalen berättade att de kände sig nöjda med livet och var redo att dö. När det gällde samtal om existentiella frågor mellan personal och de äldre uppgav 81 procent av enhetscheferna att det inträffade ofta/ibland (IV).

Enhetscheferna angav att samtal om existentiella frågor inom arbetsgruppen kunde handla om personalen själva och hur de bäst skulle stödja äldre personer och deras existentiella behov. Enhetscheferna beskrev att personalen sinsemellan diskuterade vikten av att lyssna och bekräfta den äldre personens tankar och existentiella funderingar, liksom att ha mod att stanna kvar hos dem för att undvika att skapa ytterligare ensamhet. Samtalen innehöll personalens funderingar över hur man bäst ställer frågor som kan vara känsliga, men också deras otillräcklighet och frustration över brist på tid för stödjande samtal med de äldre personerna. När det gällde samtal om existentiella frågor inom arbetsgruppen uppgav 74 procent av enhetscheferna att det inträffade ofta/ibland (IV).

\section{Stöd till vårdpersonal}

De flesta av enhetscheferna (73 procent) angav att vårdpersonal i vård och omsorg fick stöd i att samtala om existentiella frågor. Det bestod i huvudsak av individuellt stöd i form av samtal med chefen eller sjuksköterskan. Andra former av stöd var reflektion under strukturerade former ( 36 procent) eller utbildning ( 27 procent) medan 6 procent fick regelbunden handledning. Möjlighet till reflektion, men även ett stödjande och öppet arbetsklimat, nämndes av enhetscheferna som sätt att få 
personalen att känna sig trygg och säker samt flexibel i det dagliga arbetet. Kunskap om vad det innebär att åldras och färdigheter i att kommunicera nämndes också (IV).

Begränsade ekonomiska resurser, tidsbrist och samordningssvårigheter angavs som hinder för att organisera stöd till personalen i den egna organisationen. Brist på handledare som kunde samtala med personalen om existentiella frågor var andra hinder, liksom begränsningar i chefsuppdraget, samarbete och struktur i organisationen och att ekonomi gick före kvalitet. Det fanns dock en uppfattning hos vissa chefer att det inte fanns några hinder utan att det i stället handlade om prioriteringar (IV).

\section{Syn på volontärer}

Närmare hälften av de tillfrågade enheterna hade volontärer involverade i verksamheten. De vanligaste aktiviteterna som volontärerna var engagerade i var, enligt enhetscheferna, vardagliga samtal och musik, men även utomhusaktiviteter och läsning förekom. Andra volontäraktiviteter var att följa med den äldre till sjukhus eller till vårdcentral och frisören. Enhetschefer nämnde också att volontärer hjälpte till i matsal och med bakning på enheten, regelbundet eller vid särskilda händelser. Knappt hälften av enhetscheferna rapporterade att volontärerna samtalade om existentiella frågor, ofta ( 3 procent), ibland ( 32 procent) eller sällan ( 8 procent). Mer än hälften av enhetscheferna svarade att de inte visste. Enhetscheferna uppgav att de önskade mer av vissa volontäraktiviteter, som att samtala om existentiella frågor med de äldre, vardagliga samtal samt promenader/utevistelser (IV). (Se figur 3) 


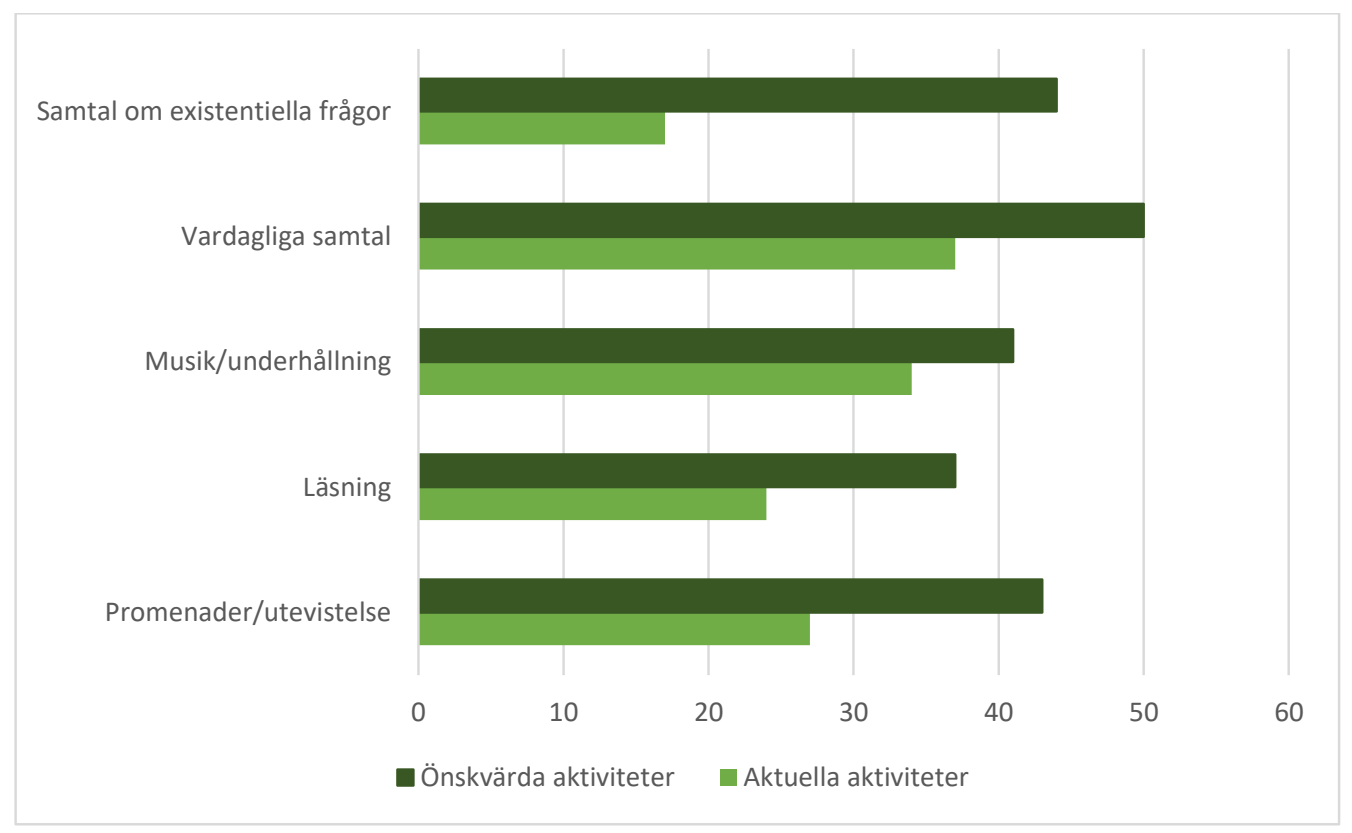

Figur 3. Enhetschefers syn på volontärers aktiviteter, aktuella och önskvärda, presenterat i antal svar $(n=60)$.

Vid de enheter som redan hade volontärer involverade angav 70 procent att det inte fanns några hinder för att ha volontärer i sin verksamhet. De som ansåg att det fanns hinder beskrev att det handlade om att det fanns för få volontärer i relation till behovet, att de äldres hälsotillstånd eller volontärernas egen kompetens eller osäkerhet var begränsande faktorer. Det fanns också en medvetenhet om att volontärernas involvering var frivillig, vilket innebar att enhetscheferna inte kunde kräva något utan att volontäruppdraget skedda på volontärernas villkor. Endast en tredjedel av cheferna deltog $\mathrm{i}$ introduktionen av volontärer på enheten, men det fanns enhetschefer som beskrev att de tog alla möjligheter att etablera kontakt när volontärer hörde av sig (IV). 


\section{DISKUSSION}

\section{Metodologiska aspekter}

Avhandlingen baseras på tre kvalitativa delstudier och en kvantitativ delstudie. I sin helhet har avhandlingen en explorativ design och de olika delstudiernas design och val av analysmetod har växt fram i relation till de tidigare fynden. Fokuset, existentiell ensamhet hos sköra äldre personer, är studerat ur flera perspektiv: vårdpersonals, volontärers och enhetschefers. Personalens perspektiv är även studerat i flera vårdkontexter. Valet att inkludera flera olika professioner och vårdkontexter, som $\mathrm{i}$ delstudie I och II, gjordes för att få en förståelse hur personal uppfattar existentiell ensamhet i olika kontexter. I delstudie II studerades kontexterna utifrån det ontologiska antagande att världen består av flera verkligheter, multiple realities, är konstruerad, kontextbunden och holistisk (Lincoln \& Guba, 1985). Vi valde att studera de fyra vårdkontexter där äldre personer får vård, hemvård, särskilt boende, sjukhusvård och palliativ vård, och där det finns en specifik vårdplats att relatera till (II). När det gäller volontärer gjordes valet att studera deras erfarenheter (III) med anledning av att de var en grupp som utöver vårdpersonal möter sköra äldre personer som känner sig ensamma eller upplever existentiell ensamhet $\mathrm{i}$ såväl den äldre personens hem som på mötesplatser och i särskilt boende. När det gäller delstudie IV:s fokus på enhetschefer, tillkom forskningsfrågor eftersom det framkommit i de tidigare studierna att vårdpersonal hade olika förutsättningar i form av stöd och handledning och eftersom det saknades kunskap om i vilken omfattning volontärer är involverade $\mathrm{i}$ vården av äldre personer i deras verksamheter.

De olika delstudiernas trovärdighet, trustworthiness, kommer att diskuteras utifrån (Guba, 1981) kvalitetsbegrepp. En del i en studies trovärdighet är att visa de svagheter som finns, vilket inte utesluter att studierna även har metodologiska styrkor. De kvalitativa delstudierna kommer att diskuteras utifrån tillförlitlighet, verifierbarhet, pålitlighet och överförbarhet, medan den kvantitativa delstudien kommer att diskuteras utifrån intern och extern validitet. 


\section{Trovärdighet studie I-III}

\section{Tillförlitlighet}

En studies design påverkar tillförlitligheten. Intentionen med att inkludera olika professioner och vårdkontexter (I, II) var för att öka möjligheten att ge en så "sann bild" som möjligt. Enligt Graneheim and Lundman (2004) läggs grunden till en studies tillförlitlighet redan vid design, det vill säga vilka deltagare som ska ingå och på vilket sätt data samlas in. En viktig aspekt i kvalitativa studier är att säkerställa variation. De flesta deltagarna var kvinnor, vilket inte är förvånande eftersom kvinnor är överrepresenterade i vårdyrken. Majoriteten var undersköterskor och sjuksköterskor, men även andra professioner var representerade. Det fanns även en variation när det gäller ålder och erfarenhet. I varje verksamhet som ingick i LONE-studien fanns en kontaktperson som även var den person som deltagarna anmälde sitt intresse till. Det gjorde att vi som genomförde datainsamlingen inte hade kontakt med deltagarna före fokusgruppsintervjuerna för att värna deltagarnas autonomi och minska forskarnas eventuella påverkan. Kontaktpersonerna var även gate-keepers i LONEstudien och gav oss tillträde till de olika verksamheterna (Polit \& Beck, 2012). Det finns en risk att kontaktpersonerna kan ha påverkat och uppmuntrat enskilda personer att delta som annars inte hade gjort det. En anledning till det skulle kunna vara att kontaktpersonen ville vara oss i LONE-studien till lags eller att vissa personer antogs tillföra kunskap eller ställa verksamheten i god dager och skulle i så fall kunna vara ett uttryck för gate-keeper bias. En annan risk är att de som valde att delta gjorde det för att de hade ett intresse av existentiella frågor. Det kan i sin tur ha påverkat resultatet i den meningen att vårdpersonalens osäkerhet och rädsla inför existentiella frågor sannolikt kan ha fler dimensioner än de som har framkommit i våra studier.

Valet av datainsamlingsmetod påverkar studiens tillförlitlighet. Datainsamlingen till delstudie I och II, och som en del i delstudie III, genomfördes med fokusgrupper. Valet att använda fokusgruppsintervjuer syftade till att inhämta olika erfarenheter hos deltagarna och att få en bredd av erfarenheter samt åstadkomma interaktion i gruppen (Kreuger \& Casey, 2015). För att säkerställa att de diskussioner som fördes under fokusgruppsintervjun skulle ge oss svar på forskningsfrågorna, genomfördes pilotintervjuer för att testa såväl intervjuguider som format (I, II, III). Den första pilotintervjun genomfördes med en grupp om fem personer där samtliga var sjuksköterskor. Pilotintervjun gav oss insikten att det var svårt att börja prata om existentiell ensamhet utan att ge konkreta exempel på vad det kunde vara. Förutom smärre justeringar av frågor i intervjuguiden gjordes därför tillägget att mer tydligt 
efterfråga deltagarnas konkreta berättelser. Det kom senare att få konsekvenser för hur materialet analyserades.

Berättelserna visade sig öppna upp för samtal om att möta ensamhet och existentiell ensamhet, även om berättelserna hade olika djup och varierande personligt engagemang. Att berättelserna hade olika djup kan dels bero på att personalen hade reflekterat över existentiell ensamhet i olika omfattning eller att klimatet i grupperna varierade. Det är möjligt att det fanns grupper där personerna inte var tillräckligt trygga med varandra och att dela sina personliga berättelser. Att berätta om konkreta situationer man ställts inför kan trots allt vara ett sätt att visa sin sårbarhet. Ytterligare en aspekt som kan ha påverkat är antalet personer som deltog. I fokusgrupperna som låg till grund för delstudie I och II varierade antalet mellan tre och åtta personer. Trots att Kreuger och Caseys (2015) rekommendation när det gäller antalet deltagare är 58 personer, nämns också fördelen med ett mindre antal personer när det gäller mer känsliga ämnen. Dock är vår bedömning att klimatet och i vad mån deltagarna kände sig trygga med varandra hade större betydelse än antalet deltagare, vilket innebär att deltagarna fick komma till tals i den mån de ville.

Fokusgruppsintervjuerna i delstudie (II) som utgjorde underlag för fyra så kallade case kompletterades med telefonintervjuer med kontaktpersonen i respektive verksamhet. Det gjordes för att fă en fördjupad kontextbeskrivning, det som av Guba (1981) beskrivs som thick description. Trots att det i varje case ingick två eller tre fokusgrupper fanns det en risk att bilden av kontexten blev förenklad vilket kan äventyra både tillförlitlighet och överförbarhet. Samtidigt kan variationen av professioner i varje fokusgrupp bidra med olika perspektiv och därmed öka möjligheten att få en bild som motsvarar verkligheten. Därutöver bidrog telefonintervjuerna med värdefull information som användes för att förstå resultaten, inte minst i cross-case-analysen. Enligt Hyett, Kenny och Dickson-Swift (2014) ska en kontextbeskrivning ge en tydlig bild av varje kontext och är därmed av särskild vikt för att läsaren ska få en bild av det specifika sammanhanget som studerats, vilket i sin tur påverkar case-studiens trovärdighet.

Datainsamlingen i delstudie III bestod av en kombination av fokusgruppsintervjuer och individuella intervjuer. Valet att även inkludera individuella intervjuer gjordes utifrån en önskan att kunna fördjupa berättelserna om existentiell ensamhet och om volontärernas egna motiv för att vara volontär. Att fokusgruppsintervjuerna med volontärer inte hade samma djup som personalintervjuerna kan bero på att 
volontärerna som regel inte kände varandra sedan tidigare. Att kombinera två datainsamlingsmetoder kan således kompensera för respektive metods begränsningar och framhäva deras respektive fördelar (Shenton, 2004). Förutom triangulering av de data som samlades in, har även flera forskare deltagit i datainsamling och analys för att på så vis stärka studiernas tillförlitlighet (Guba, 1981). Genom att flera forskare deltar i analysen kan olika uppfattningar ställas mot varandra. Det är även ett sätt att utmana varandras förförståelse. Så har det varit i delstudie I, II och III i olika faser av analysprocessen. Det är också ett sätt att arbeta med närhet och distans så att någon eller två av forskarna arbetar nära materialet och någon annan i forskargruppen kommer in och stämmer av tolkningarna mot intervjumaterialet som alla inledningsvis tagit del av.

Vid de individuella intervjuerna användes member-checks med deltagaren i slutet av intervjun för att stämma av det som sagt. Guba (1981) menar att member-check är den enskilt viktigaste handlingen som forskaren kan göra för att stärka tillförlitligheten. Member-checks kan göras under olika delar av forskningsprocessen. Under de individuella intervjuerna fördes anteckningar som lästes upp och utrymme gavs för deltagaren att lägga till eller förtydliga. Det ledde till att ett par av deltagarna utvecklade sina tankegångar när det hade fătt höra vad de hade sagt, vilket kan ses som ett sätt att uppmuntra deltagarna att vara uppriktiga i stället för att berätta vad de tror att forskarna vill höra eller framstå i god dager (Shenton, 2004). Att använda anteckningarna som member-checks var inte förutbestämt utan skedde på grund av min intuition när jag skulle avsluta pilotintervjun. Det kändes viktigt att delge deltagaren vad jag hade lyssnat in under intervjun och handlade även om min trovärdighet som intervjuare. Det föll väl ut och deltagaren bekräftade och utvecklade någon aspekt ytterligare. Det gjorde att jag efter diskussion i forskargruppen fortsatte att göra så, men först efter att ha frågat deltagarna om de ville ta del av anteckningarna. Samtliga deltagare utom en ville höra en sammanfattning. Ytterligare ett sätt att stärka tillförlitligheten är att använda peer scrutiny (Shenton, 2004), det vill säga att andra personer utanför den grupp av forskare som har genomfört studien granskar design, metodval och slutsatser. De tre första studierna har presenterats i olika sammanhang, såväl i projektets referensgrupp som består av representanter för gruppen äldre personer, vårdpersonal, närstående och volontärer, som i andra kollegiala sammanhang utanför LONE-studien och vid konferenser. Respons och frågor vid dessa tillfällen har bekräftat resultaten, men också bidragit med nya tankar och ifrågasatt förgivettagna föreställningar. Det har exempelvis handlat om olika synsätt på ensamhet, och hur långt det är rimligt att förvänta sig att vårdpersonal ska klara av 
att möta existentiella frågor utan vidare stöd. I de tre kvalitativa delstudierna har citat använts för att illustrera resultatet och våra tolkningar

En annan aspekt av tillförlitlighet är om forskaren besitter den kompetens som krävs. Min insats som doktorand $\mathrm{i}$ datainsamlingen har varit att vara moderator $\mathrm{i}$ fokusgruppsintervjuerna, att genomföra telefonintervjuer och att genomföra de individuella intervjuerna. I fokusgruppsintervjuerna deltog alltid en handledare och var till stor hjälp både under intervjun och efteråt. Direkt efter varje intervju reflekterade vi tillsammans över intrycken av intervjun och ifall det var något vi behövde tänka på till nästkommande intervju, det som Shenton (2004) beskriver som debriefing sessions. Att arbeta tillsammans med seniora forskare under datainsamlingen har varit en fördel för mitt lärande. De individuella intervjuerna genomfördes av mig på egen hand, men det var under den senare delen av forskarutbildningen. Den första individuella intervjun, pilotintervjun, genomlyssnades av en av handledarna för att ge feedback på min intervjuteknik, avseende sättet att ställa frågor, invänta svar och följa upp eventuella oklarheter. Även den text som intervjun genererade, lästes igenom. Telefonintervjuerna genomfördes självständigt, däremot hade de frågor som skulle ställas diskuterats i projektgruppen för LONE-studien $i$ förväg för att inte missa aspekter av värde. Eftersom kontaktpersonerna hade varit delaktiga i planeringen av fokusgrupperna fanns det en etablerad kontakt mellan dem och mig innan telefonintervjuerna genomfördes.

\section{Verifierbarhet}

Studiernas verifierbarhet handlar om att visa hur analysen har gått till och att beskriva vilka olika steg som tagits ifall någon forskare skulle vilja göra en liknande studie i framtiden (Shenton, 2004). Verifierbarhet innebär också att på olika sätt illustrera tolkningarna så att läsaren kan bedöma om de är rimliga. Metodbeskrivningar och analysbeskrivningar finns tillgängliga och ambitionen har varit att de ska vara både tydliga och begripliga så att läsaren kan följa de olika stegen. Analyserna i delstudie I och II har båda vuxit fram succesivt varför det har varit särskilt angeläget att beskriva analysprocessen då studiernas design inte har följt en vedertagen metodbeskrivning från början till slut.

Valet att använda deltagarnas berättelser som analysenheter väcktes efter att de första fokusgruppsintervjuerna hade genomförts. Deltagarna hade delat ett flertal berättelser med varandra och dessa berättelser gjorde intryck och bedömdes som värdefulla att utforska. Att gå via någons berättelse är ett sätt att få tillgång till en annan människas 
livsvärld, där erfarenheter och händelser beskrivs med personens egna ord. Berättelserna handlade om personalens erfarenheter av att möta existentiell ensamhet hos sköra äldre, och kunde ta sig många olika uttryck. Därför valdes Emmy van Deurzens $(1998 ; 2012)$ teoretiska ramverk om den personliga livsvärlden med fyra dimensioner som en sorteringsram att arbeta utifrån. Att använda van Deurzens ramverk underlättade för att förstå och förklara andra aspekter av existentiell ensamhet, såsom den sköra kroppen, relationer till sig själv och andra. När alla berättelser var sorterade in i de fyra dimensionerna analyserades de med hjälp av analytiska frågor som vi tillsammans formulerade i forskargruppen. Berättelserna som extraherats från fokusgruppsmaterialet var det material som låg till grund för analysen. Inga generella reflektioner eller mellanprat och övergångar som ofta finns i diskussioner och samtal mellan människor fanns med. Genom att berättelserna extraherats från den övriga texten, och så att säga tagits ur sitt sammanhang, fanns inte längre någon information som påminde om vilken profession som berättaren hade, eller i vilken kontext respektive berättelse kom ifrån. Det bidrog till att personen bakom berättelse och texten framträdde tydligare. Min förförståelse kunde sättas åt sidan i det skedet genom att berättelserna hade avprofessionaliserats och inte längre tillhörde en specifik kontext.

\section{Pålitlighet}

Studiernas pålitlighet handlar om det finns risk för att forskarens förförståelse har påverkat resultatet och om data förändras över tid (Polit \& Beck, 2012). Det gäller i synnerhet om datainsamling sker under en längre tid. När det gällde fokusgruppsintervjuer med vårdpersonal och volontärer (I-III) var datainsamlingen utsträckt. Anledningen till att datainsamlingen utökades med fler fokusgruppsintervjuer var att vi ville ha en större variation när det gällde vårdkontexter (I, II) och fler volontärorganisationer (III). Denna utökning skulle kunna utgöra ett potentiellt hot mot studiens pålitlighet, genom att förförståelsen kan förändras över tid, att frågorna ställdes på ett annat sätt eller att vissa aspekter togs för givna. För att minska denna risk användes samma intervjuguide vid samtliga intervjuer med vårdpersonal respektive volontärer. Intervjuguiderna förändrades inte under tiden som datainsamlingen pågick, möjligen användes intervjuguiden något friare allteftersom fler intervjuer genomfördes i den meningen att moderatorn var mer följsam mot deltagarna och lät dem prata vidare för att sedan backa tillbaka till guiden. Det var alltid två personer som genomförde fokusgruppsintervjuerna och hjälptes åt, vilket kan ses som en styrka, och ett stöd för att intervjuguiden skulle följas och att alla diskussioner skulle följas upp. Proceduren att introducera intervjuerna med frågor om 
ensamhet tidigt $\mathrm{i}$ intervjun för att sedan övergå till existentiell ensamhet, följdes exempelvis vid alla tillfällen. En annan aspekt av pålitlighet är att beskriva analysarbetets gång så att läsaren kan avgöra studiens trovärdighet och överförbarhet (Shenton, 2004) vilket har gjorts i de enskilda delstudierna. Som doktorand har jag heller inte varit ensam i analyserna utan arbetat tillsammans med någon annan i forskargruppen och forskarna respektive bidrag till varje studie redovisas i artiklarna. Forskarnas förförståelse och hur den hanteras och lyfts fram är också relaterad till en studies pålitlighet (Shenton, 2004). I avhandlingens fyra delstudier har alla forskare en sjuksköterskebakgrund, om än inom olika områden och med olika forskarerfarenheter. Diskussioner har förts kontinuerligt och skett under både planering av kommande studier och analys för att utmana varandras förförståelse. Eftersom det har pågått flera parallella studier inom ramen för LONE-studien har diskussioner kring förförståelsen varit särskilt viktig så att inte resultat från en tidigare studie påverkat analysen $\mathrm{i}$ en annan studie.

\section{Överförbarhet}

En studies överförbarhet är avhängig hur urval och kontext beskrivs, för att möjliggöra för läsaren att avgöra om resultatet är överförbart till andra kontexter, och i så fall till vilka (Shenton, 2004). Det handlar även om tillgång till bakgrundsinformation om deltagare och en utförlig kontextbeskrivning, en så kallad thick description (Guba 1981; Shenton, 2004). I delstudie II genomfördes telefonintervjuer med kontaktpersoner i varje verksamhet för att samla in just en sådan beskrivning. Överförbarheten handlar också om att tillhandahålla en klar beskrivning av fenomenet som ska studeras. Då existentiell ensamhet är ett komplext begrepp och fenomen har vi behövt tydliggöra vad vi menar med begreppet, både under datainsamling och vid presentation av resultaten. Överförbarheten avser i en vidare mening i vilken mån resultatet från våra studier kan överföras till andra kontexter. Av den anledningen har vi eftersträvat variation, både när det gäller deltagare och kontexter, för att öka möjligheten att överföra studiernas resultat. Det är dock viktigt att komma ihåg att studierna är genomförda i en svensk kontext, vilket begränsar överförbarheten utanför Skandinavien, eftersom både organiseringen av vården till äldre personer och volontärverksamheter skiljer sig åt internationellt. Dock är fenomenet existentiell ensamhet med all sannolikhet universellt och giltigt $\mathrm{i}$ ett internationellt perspektiv, även om resultatet gäller sköra äldre personer i behov av långvarig vård och omsorg och därför ska ses i det sammanhanget. 


\section{Trovärdighet delstudie IV}

Den enkät som användes i delstudie IV skapades av oss själva eftersom det inte fanns något instrument som täckte det vi ville kartlägga, det vill säga om existentiella frågor var en del av samtalen inom äldrevården, och enhetschefers syn på vårdpersonals och volontärers behov av stöd. Studien var en tvärsnittsstudie för att få en ögonblicksbild och utan avsikten att studien skulle återupprepas eller att enkäten skulle utvecklas till ett skattningsinstrument. Av den anledningen är inte enkäten eller dess frågor psykometriskt utvärderade. Det slumpmässiga urvalet av enhetschefer ökar sannolikheten att gruppen ska vara representativ för hela målpopulationen. Resultatet visade att ungefär hälften av enhetscheferna kom från hemtjänst och hälften från särskilt boende vilket är i linje med respektive andel enheter enligt Socialstyrelsens Öppna jämförelser (2018). Nästan hälften av cheferna hade arbetat som ledare inom vård och omsorg i mer än 10 år, vilket tyder på att det främst är de erfarna cheferna som har besvarat enkäten, vilket i sin tur kan påverka den interna och externa validiteten.

\section{Intern validitet}

Den interna validiteten påverkas av om de frågor som ingick i enkäten mäter det som var tänkt, det vill säga uppfattade enhetscheferna det som var avsett, och uppfattade alla enhetschefer frågorna på samma sätt? För att skapa så tydliga och valida frågor som möjligt, och därmed stärka den interna validiteten, diskuterades frågorna vid ett seminarium om enkätmetodik där forskare inom hälsovetenskap gruppvis diskuterade frågorna och lämnade förslag på förbättringar. Efter justeringar skickades enkäten ut som ett test online inom projektgruppen i LONE-studien. Den omgången ledde också till konstruktiva justeringar av frågorna, men även synpunkter på informationsbrev och enkätens utseende. För att ytterligare stärka den interna validiteten testades hela frågeformuläret med think-aloud-metoden (Dillman m.fl., 2014), på svenska benämnd läsa högt-metoden (Wenemark, 2017). En person med tidigare erfarenhet som enhetschef fick ta emot enkäten via e-post. Personen fick i ett telefonsamtal öppna länken och besvara frågorna samtidigt som hen läste frågorna och tänkte högt hur frågorna uppfattades. Efteråt diskuterade vi tillsammans och kom fram till några ändringar som bland annat handlade om formuleringar av svarsalternativ. Dessa tre sätt att ta fram frågorna för att stärka validiteten kan ses som att testa enkätens face validity (Polit \& Beck, 2012). Trots detta kan man inte utesluta att frågorna kan ha uppfattats olika av enhetscheferna i studien. Det förekom internt bortfall på ett par frågor. Det högsta bortfallet på en enskild fråga gällde 8 personer som inte besvarat frågan om enhetschefernas ålder medan merparten av övriga interna bortfall var mellan 1-3 personer som inte besvarat en enskild fråga. Det låga interna bortfallet 
stärker den interna validiteten. En av frågorna i enkäten fick exkluderas i analysen på grund av att svarsalternativen av misstag presenterades i fel ordning. Frågan gällde om enhetscheferna associerade existentiell ensamhet till livet, döden, frihet och ensamhet (se Appendix). Trots att svaren på frågan inte har redovisats kan den ha varit viktigt eftersom frågan gav enhetscheferna möjlighet att tidigt reflektera över begreppet existentiell ensamhet.

\section{Extern validitet}

Det största hotet mot den externa validiteten är det stora externa bortfallet. Svarsfrekvensen var endast 29 procent trots tre påminnelser. En introduktionsfilm fanns bifogad som länk i e-brevet, men endast ett 60-tal personer hade öppnat och sett filmen. Ett par enhetschefer kontaktade mig eftersom de inte kunde öppna länken till enkäten, vilket i de flesta fall kunde lösas genom att de öppnade länken med en annan webbläsare. Tidsbrist och enhetschefernas höga arbetsbelastning vara andra skäl till att de inte besvarat enkäten. Det slumpmässiga urvalet (Dillman m.fl., 2014; Polit \& Beck, 2012) talar för att de som har besvarat enkäten trots allt är representativa för målpopulationen. Det är däremot möjligt att de som svarat, i högre grad än de som inte besvarat enkäten, har ansett ämnet existentiell ensamhet som angeläget och viktigt. Det skulle exempelvis kunna innebära att de svar som har inkommit möjligen ger en mer positiv bild av det stöd som enhetscheferna ger till personalen. Det är möjligt att använda flera distributionssätt, som brev, e-post och telefon, för att öka svarsfrekvensen (Dillman m.fl., 2014). Detta bör dock ställas i relation till om det är forskningsetiskt försvarbart att belasta verksamheterna ytterligare. Studiens resultat bör alltså tolkas med viss försiktighet med tanke på den låga svarsfrekvensen. Samtidigt fanns en stor överenskommelse mellan enhetschefernas skattningar, deras fritextsvar och resultaten från delstudie I och II, och i viss mån även delstudie III.

\section{Resultatdiskussion}

Ett av de viktigaste fynden i denna avhandling var vårdpersonalens osäkerhet och rädsla för att samtala om existentiella frågor. Detta framkom i intervjuerna med personalen och i deras berättelser om möten med äldre personers existentiella ensamhet och bekräftas också av enhetscheferna som uppgav personalens osäkerhet som det största hindret för existentiella samtal, följt av ovilja/olust. Enhetscheferna uppfattade att existentiell ensamhet förekom hos äldre personer och uppgav att de, tillsammans med sjuksköterskorna, stod för det huvudsakliga stödet till personalen. 
Även vissa volontärer kände sig osäkra, medan andra kände en sorts trygghet och beskrev sig själva som en medmänniska. Relationen till den äldre hade betydelse för att möta existentiella frågor och upplevdes som betydelsefulla av både personal och volontärer. Ett annat viktigt fynd är att trots utmaningen i att möta äldre personers existentiella ensamhet upplevde personalen att det var meningsfullt. På liknande sätt upplevde volontärer, om än i olika grad, att uppdraget gav mening och lindrade inte bara den andres ensamhet utan också den egna ensamheten. Resultatet kommer att diskuteras utifrån ovanstående huvudfynd och i relation till: (a) Relationens betydelse för att möta existentiell ensamhet, (b) Vårdkontextens betydelse för att möta existentiell ensamhet, samt (c) Stöd till personal i att möta existentiell ensamhet.

\section{Relationens betydelse för att möta existentiell ensamhet}

För att kunna möta och samtala om existentiella frågor krävs en tillitsfull relation till den andre. Resultatet visade att såväl personal som volontärer var medvetna om, och beskrev betydelsen av, att skapa tillitsfulla relationer för att kunna möta existentiella frågor (II). Den betydelsefulla relationen innebar att man möttes på ett mellanmänskligt och existentiellt plan. Det framkom att vissa möten påverkade personalen under lång tid efteråt och fanns kvar som starka minnen, inte minst de goda möten där man som personal upplevde att det fanns en ömsesidig förståelse (I). Buber (1995) beskriver ett gott möte som ett möte med autenticitet och ömsesidighet mellan två människor, ett äkta samtal. Ett äkta samtal kan inte planeras eller förutses, utan uppstår i stunden, menar Buber, det äkta uppenbarar sig i mötet. Även vårdpersonal och volontärer beskrev att det är något som sker i stunden och under vissa omständigheter (I, III). Todres, Galvin och Dahlberg (2014) beskriver vårdande som en strävan efter sådana möten som innebär ett mänskligt delande, en närhet och en föreställning om det gemensamma mänskliga. Sådana ögonblick när "allt stämmer" beskrivs av McCormack, Dewing, och McCance (2011) som person-centred moments. Schön Persson, Nilsson Lindström, Pettersson, Nilsson och Blomqvist (2018) beskriver en god relation som att ha ett nära band där man kan vara personlig utan att gå över gränsen till privat, men också vikten av att ha meningsfull tid tillsammans med den äldre, där parterna lär känna varandra över en längre tid. Även Hedman, Häggström, Mamhidir och Pöder (2019) beskriver hur sjuksköterskor betonar värdet av relationer med de äldre som är personliga, bekräftande och tillitsfulla och baserade på ömsesidighet och respekt. Detta är i linje med resultatet i denna avhandling som visar att personalen påverkades både professionellt och personligt av att möta och dela en annan människas innersta tankar om livet och döden (I). Även volontärerna 
påverkades av mötet. Samtidigt fanns det en stor variation bland volontärerna i vilken form av relation man önskade, där vissa ville ha kortvariga och mindre personliga relationer (III). Dock kunde kortvariga relationer även innehålla uppriktighet, närhet och värme. Liknande resultat visade en studie där patienter, närstående, volontärer och vårdpersonal deltog (Dodd m.fl., 2018). Studien visade att personkemi mellan patienten och volontären var viktig, liksom att den äldre personens möjlighet att få berätta om sin situation och sitt liv för någon utomstående som inte redan kände till allt. Det är således viktigt att ta tillvara, personalens och volontärers, vilja att skapa meningsfulla relationer med den äldre som grund för existentiella samtal, samtidigt som det är viktigt att ta hänsyn till deras respektive möjligheter och egen kompetens att skapa tillitsfulla relationer.

Att möta äldre personers ensamhet $\mathrm{i}$ allmänhet och existentiell ensamhet i synnerhet kan vara meningsskapande för såväl personal som volontärer. Resultatet visade att volontärer angav att relationer var betydelsefulla och bidrog till att volontäruppdraget kändes meningsfullt. Volontärerna beskrev även att det var just relationerna som bidrog till känslan av gemenskap och samhörighet. Att som volontär ha samtal med äldre personer om existentiella frågor och livserfarenheter på en djupare nivå gav nya insikter och ledde även till egen utveckling (III). Betydelsen av att få ta del av andras livsberättelser finns beskrivet i flera studier (Planalp, Trost \& Berry, 2011; Stephens m.fl., 2016), men även betydelsen av ömsesidighet i mötet. En studie av Greenwood, Gordon, Pavlou och Bolton (2018) lyfte fram det ömsesidiga utbytet som innebar att rollen som volontär inte enbart handlar om att ge utan även om att få någonting tillbaka. Det kräver dock att båda parter vill dela ett existentiellt möte (jfr Minton, Isaacson, Varilek, Stadick \& O'Connell-Persaud, 2018). Resultatet i denna avhandling visade att mötet med ensamhet hos äldre personer även lindrade volontärernas egen ensamhet (III). Szebehely, Stranz och Strandell (2017) poängterar att det som är betydelsefullt och påverkar människor som möter och vårdar äldre personer, är känslan av att nå en annan människa (Szebehely m.fl., 2017). Även personalen i delstudie I lyfte fram hur meningsfullt de tyckte det var att möta äldre personer som upplevdes existentiellt ensamma. De angav att empati, medkänsla, mod, nyfikenhet och öppenhet samt att kunna lyssna och reflektera utan värdering var betydelsefulla egenskaper i mötet (I). Volontärerna, å sin sida, beskrev snarare betydelsen av att "vara medmänniska" (III). Det ligger i linje med en studie av Greenwood med flera (2018) om att vara volontär till personer med demenssjukdom, där uppdraget förändrade deras syn och att de inte längre såg dem som personer med en sjukdom utan i stället som människor. Volontäruppdraget beskrevs som en personlig och 
mänsklig livserfarenhet. Följaktligen är relationer betydelsefulla och meningsskapande för båda parter. Däremot krävs vissa egenskaper och förmågor hos vårdpersonal respektive volontärer för att skapa och upprätthålla dessa meningsfulla relationer, vilket är angelägen kunskap för chefer i vård och omsorg och företrädare i volontärorganisationer.

Även om personal och volontärer är fokuserade på relationen till den andre med målsättningen att skapa ett gott möte finns det en rad hinder för att samtal om existentiella frågor ska kunna ske. De barriärer som identifierades i delstudie I handlade bland annat om den äldres kroppsliga begränsningar som exempelvis kognitiv nedsättning vilket medförde svårigheter att uttrycka sig och att personalen upplevde att de äldre personerna själva var osäkra och rädda för att prata om existentiella frågor (I). Enhetscheferna i studie IV uppgav samma sak. De skattade dock att kognitiv svikt och afasi var ett större hinder för samtal om existentiella frågor än de äldres osäkerhet och ovilja att samtala om dessa frågor (IV). En studie med personer som hade afasi visade att de kände sig exkluderade när de inte längre kunde uttrycka sig som tänkande och handlande människor (Hjelmblink, Bernsten, Uvhagen, Kunkel \& Holmström, 2007). Även Nyström (2006) fann i sin studie av personer med afasi att de kände sig existentiellt ensamma och att känslan förstärktes när de blev ignorerade eller om problemet bagatelliserades. Det finns således en risk att personer som har svårt att uttrycka sig är särskilt utsatta för existentiell ensamhet. Samtidigt beskriver personalen att de upplever stora utmaningar i att möta just denna grupp. Det är därför viktigt att inte enbart fokusera på samtal som metod för att möta äldre personers existentiella ensamhet. Resultatet i delstudie II visade att personalen upplevde att äldre personer ofta sökte kroppslig närhet, exempelvis genom att sträcka sig efter en hand att hålla i, för att känna närvaron av en annan människa och tolkade det som ett tecken på existentiell ensamhet. Ozolins (2011) beskriver att beröring kan vara vårdande och att det avgörs av den mellanmänskliga rörelsen, snarare är beröringen som sådan. Beröring kan också bidra till att skapa förankring och ge sammanhang till den äldre och "genom sin förankrande karaktär kan beröring mellan människor lindra upplevd ensamhet" (Ozolins, 2011, s. 106). Det finns ett flertal studier utförda inom olika vårdkontexter, om upplevelsen av beröring i form av beröringsmassage. Studierna visar att massagen ökar känslan av kroppslig och mental avslappning och kan bidra till att för en stund känna sig befriad från sjukdom, lidande och tunga tankar (Cronfalk, Strang, Ternestedt \& Friedrichsen, 2009). Beröringsmassagen beskrevs även ge en känsla av att komma till ro, som en existentiell frid, och lindra känslor av fysisk, social och existentiell ensamhet. En förutsättning för att 
beröringen ska vara vårdande är dock att patienten känner sig sedd och bekräftad som en person, och känner sig värd den tid och uppmärksamhet som beröringen tar (Ozolins, Hörberg \& Dahlberg, 2015). Om personal istället använder beröring utan samspel och empati kan det istället leda till oro och smärta och skapa distansering (Ozolins, 2011) och existentiell ensamhet (Sand \& Strang, 2006). Relationen är således en grundläggande aspekt även för icke-verbala möten. Även Sundin, Jansson och Norberg (2000) fann att en förutsättning för en god kommunikation mellan vårdare och personer med afasi var att det fanns en närhet, och att beröring öppnade upp för en ömsesidig förståelse. Studier inom vården till personer med demenssjukdom visar att även om effekten av beröringsmassage kan vara svår att påvisa, upplever vårdpersonalen det positivt att ge massage och att det får dem att känna sig värdefulla och professionella (Skovdahl, Sörlie \& Kihlgren, 2007). Det finns dock ett behov av ytterligare kunskap om olika interventioner. Interventioner som med relationen som grund kan stödja personalen att möta existentiell ensamhet, såväl verbalt som icke-verbalt, för att öka tillfredsställelsen hos både personalen och äldre personer i deras vård.

\section{Vårdkontextens betydelse för att möta existentiell ensamhet}

Det sammanhang som vården bedrivs $\mathrm{i}$ och den inramning och inriktning som vården har, har betydelse för hur vårdpersonal uppfattar existentiell ensamhet, men även för deras möjligheter att möta den. Resultatet visade att beroende på om vården gavs i hemmet eller på institution fanns det olika förutsättningar för mötet (II). Resultatet visade även att vårdens inriktning i de fyra vårdkontexterna var olika: $\mathrm{i}$ hemvård och på särskilt boende syftar vård och omsorg till att erbjuda och skapa en meningsfull tillvaro, vården på sjukhus fokuserar främst på att bota, medan palliativ vård främst syftar till att ge vård i livets slut. Att vårdens inriktning skilde mellan olika kontext kan förklara varför personal inom hemvård och på särskilt boende främst kopplade existentiell ensamhet till livet, medan personal i palliativ vård och på sjukhus främst kopplade den till döden (II). Resultatet visade att vårdkontexten även hade betydelse för vilka förutsättningar, och tillgång till stöd, personalen hade. Det var endast personal inom palliativ vård som erbjöds regelbunden handledning och organiserade möten för reflektion som en integrerad del av verksamheten. Detta saknades vanligen både i hemvård, på särskilt boende samt på sjukhus (II). Vårdmiljön är en komplex enhet som består av både en fysisk och psykosocial miljö (se Browall, Koinberg, Falk \& Wijk, 2013). När det gäller den fysiska miljön behöver det finnas utrymmen där vårdpersonal och volontärer kan samtala i 
avskildhet med den äldre och att det är utrymmen som bjuder in till den sortens samtal (van der Vaart \& van Oudenaarden, 2018). Det ställer krav på den institutionella vården att tillgodose utrymmen för både avskildhet och aktivitet men även att se till så att den äldre personen har möjlighet att välja och kan balansera sitt behov av avskildhet med behov av att umgås med andra (Baxter, Sandman, Björk, Lood \& Edvardsson, 2019). Vårdmiljön skapar mening i sig själv, i den bemärkelsen att materiella saker som finns i den äldres hem eller som den äldre tagit med sig vid inflyttning till särskilt boende kan ha mening. Resultatet visade att hemmet som plats kunde bidra till att bevara den äldres identitet, samtidigt som personal i hemvård beskrev att hemmet också kunde vara isolerande (II). I en studie om platsens betydelse för välbefinnande i familjer med kronisk sjukdom beskrevs platsen som trygghetsskapande och där platser på olika sätt var associerade med aktiviteter som man tyckt om och en plats för avkoppling (Årestedt, Benzein, Persson \& Rämgård, 2016). Det betyder att om miljön är meningsskapande så kan man känna sig mindre ensam och främmande, både inför sig själv och andra. Browall med flera (2013) genomförde en studie inom onkologisk vård som visade att den psykosociala miljön var överordnad den fysiska. En aspekt av psykosocial miljö handlar om tid och tempo. Resultatet $i$ avhandlingen visade att det fanns olika förutsättningar beroende på om vården gavs i hemmet eller på institution där personalen på sjukhus exempelvis angav att korta vårdtider och bristande kontinuitet var hinder för att skapa tillitsfulla relationer (II). Andra institutionella hinder för relationskapande kan vara förväntningar som är svåra att leva upp till. En studie av Banerjee med flera (2016) visade att sjuksköterskor i en onkologisk kontext kände sig splittrade mellan olika förväntningar. De ville vara ett stöd för sina patienter och deras familjer, men upplevde förväntningar från kollegor och verksamheten på att $\mathrm{i}$ första hand fokusera på och behandla medicinska symtom. Ett annat hinder för att vara närvarande i mötet var att bli avbruten och distraherad. Buber (1994) beskriver jag-du-relationen som en relation som bygger på jämlikhet, ett genuint intresse för den andre och ömsesidighet. Det förutsätter att det finns möjlighet att vara närvarande, men också att det finns gemensamma värderingar och uppfattningar bland vårdpersonalen på den vård som ges. Vid planering av interventioner för att tillgodose äldre personers existentiella behov är det således viktigt att ta hänsyn till olika kontextuella förutsättningar och att ge möjlighet att anpassa innehållet till den faktiska situationen. 


\section{Stöd till personal i att möta existentiell ensamhet}

En av de största utmaningarna för vårdpersonal $\mathrm{i}$ äldrevården är att möta äldre personers existentiella funderingar om livet och döden. Personalens osäkerhet och rädsla handlade framför allt om hur man skulle närma sig, möta och besvara den äldres funderingar kring existentiella frågor (I, II, IV). Det fanns också en osäkerhet bland volontärer. Vissa volontärer undvek sådana samtal eftersom de inte kände sig bekväma i att samtala om existentiella frågor. Ett annat skäl var att de ville lindra den äldres ensamhet genom att avleda från tungsinta tankar och därför i stället fokuserade på sådant som gav glädje (III). Personalens osäkerhet inför existentiella frågor kan handla om föreställningar om vad som förväntas av en som personal och vad som ingår i den professionella rollen, som att vilja hjälpa men inte ha några svar eller lösningar. Det fanns personal som uttryckte att existentiella frågor hörde till den privata sfären och därför undvek att prata om dessa frågor (II). I en holländsk studie om existentiella frågor inom äldrevård beskrev de äldre att samtalen mest handlade om deras fysiska välmående och att det sällan gavs utrymme att prata om deras tankar och spirituella välmående, trots att personalen ansträngde sig att hitta tid för samtal (van der Vaart \& van Oudenaarden, 2018). Tid för samtal handlar även om tid att lyssna. I en metaetnografisk studie beskrivs tystnad som en del av en läkande kommunikation, men också som en paus i kommunikationen i väntan på det som ska komma att sägas (Bassett, Bingley \& Brearley, 2018). Lyssnandet är rimligtvis ett av personalens allra främsta redskap i mötet med existentiella funderingar. Personal som arbetade med personer med cancer uttryckte det som ha ett ansvar att lyssna, liksom att ha modet att våga stanna kvar, och lyssna genom att vara tyst (Browall, MelinJohansson, Strang, Danielson \& Henoch, 2010). Resultatet i denna avhandling visade att också volontärerna lyfte fram betydelsen av att lyssna, även om de menade att lyssnande kräver viss träning. De lyfte också fram vikten av att ha självkännedom och att vara klar över sina egna värderingar för att hantera existentiella frågor. Flera av volontärerna hade själva arbetat $i$ vård eller omsorg tidigare och de beskrev relationen till äldre personer som annorlunda än de man tidigare hade haft som professionell (III). I rollen som volontär kunde de i mycket högre grad tillåta sig att "bara vara", lyssna och vara en medmänniska. Det indikerar att den professionella rollen ibland kan vara en begränsning i relation till existentiella frågor och samtal där rollen som volontär ger större frihet och handlingsutrymme.

Det är alltså en risk att personalens osäkerhet medför att de äldres existentiella behov inte tillgodoses. Enhetscheferna inom hemtjänst och på särskilt boende angav att personalen främst fick stöd $i$ att möta existentiella frågor i form av individuella samtal 
med enhetschefen eller sjuksköterskan (IV). Samtidigt uppgav mer än hälften av enhetscheferna att de hade personalansvar för mellan 31 och 50 personer och en femtedel hade ansvar för mer än 50 personer (IV). Det är då rimligt att fråga sig i vilken mån de hinner att ge stöd, och i så fall på vilket sätt? En studie bland sjuksköterskor som vårdade svårt sjuka och döende patienter önskade stöd $\mathrm{i}$ att hantera sina känslor om de existentiella frågor som väckts i möten med patienter, snarare än att få bekräftelse på att man hade gjort rätt. I de fall man var i behov av stöd valde man att vända sig till sina kollegor, snarare än till sin familj eller till läkaren (Houtepen \& Hendrikx, 2003). Det visar på betydelsen av att det finns kollegor som man kan samtala med och att det finns ett arbetsklimat som främjar samtal om existentiella aspekter av vårdandet. Enhetscheferna själva uppgav ekonomiska begränsningar, svårigheter att samordna träffar och brist på ledare i existentiella frågor som anledningar till att det inte fanns ett mer formellt stöd (IV). Sjuksköterskorna i studien av Houtepen och Hendrikx (2003) uppfattade att utbildning inte hade så stor effekt, i stället handlade det om att hitta sin egen väg baserat på egna praktiska erfarenheter vilket sin tur gav kraft. Det talar för att strukturerad reflektion med kollegor är att föredra före utbildning. Det finns studier som visar att systematisk och strukturerad reflektion kan öka förståelsen för den äldre personens situation och för vad som är meningsfullt för just den personen. Ett sådant exempel är en interventionsstudie med fokus på ett palliativt förhållningssätt inom särskilt boende (Beck, 2013). Interventionen bestod av studiecirklar med återkommande diskussioner och reflektioner kring bestämda teman, bland annat "Hur kan vi bli bättre på att samtala med äldre personer om döden och andra svåra frågor?". Efter interventionen skattade personalen att de i högre grad samtalade med vårdtagarna om det som gav dem mening i livet (Beck, Jakobsson \& Edberg, 2014). Personalen i interventionsgruppen angav också att de genom interventionen hade blivit medvetna om aspekter som hindrade dem från att fokusera på relationen och mötet med vårdtagarna. De angav dock samtidigt att det saknades resurser för att arbeta efter vad de hade lärt sig (Beck, Törnquist \& Edberg, 2014). Det är i linje med resultatet i denna avhandling där enhetscheferna beskrev att samtalen om existentiella frågor inom arbetsgruppen handlade om hur personalen skulle kunna stödja de äldre i deras existentiella behov, men beskrev även personalens känsla av otillräcklighet och frustration över brist på tid för att kunna stödja de äldre (IV). Personalen i interventionsgruppen i studien av Beck och medarbetare berättade även att de saknade stöd från ledningen, trots att enhetschefer och sjuksköterskor hade varit delaktiga i interventionen (Beck, Törnquist \& Edberg, 2014). Det verkar således som att ett systematiskt och strukturerat stöd till såväl vårdpersonal som volontärer är av betydelse och kan ge möjlighet att tillvarata 
goda erfarenheter, men också vikten av att kunna dela erfarenheter när man har stött på något man upplevt som svårt att hantera. Det förutsätter dock ett systematiskt stöd från enhetschefer och sjuksköterskor och att arbetet organiseras på ett sådant sätt att möjligheter till samtal om existentiella frågor kan ges.

\section{Handlingsutrymme och tillit i organisationen}

För att vårdpersonal ska kunna skapa meningsfulla relationer och ha existentiella samtal krävs att personalen har eget handlingsutrymme när situationen så kräver och att ledarskapet och organisationen värnar detta handlingsutrymme. Tid är en central aspekt för att skapa tillit och möta den andre som person. Avhandlingens resultat visade att brist på tid, kontinuitet, men även brist på lokaler för samtal i avskildhet begränsade personalens möjligheter att skapa relationer och ha djupare samtal med de äldre (II). Samtidigt har personalens handlingsutrymme betydelse vilket kan vara en utmaning $\mathrm{i}$ vården. Wolf med medarbetare (2012) visade att vårdmiljön på en medicinsk vårdavdelning med starkt fokus på rutiner begränsade både personals och patienters möjligheter att skapa en relation. Möjligheterna att påverka det dagliga arbetet har minskat i äldreomsorgen på senare år, främst inom hemtjänst. Handlingsutrymmet, det vill säga andelen som uppgav att de hade möjlighet att vara flexibla och kunna påverka det dagliga arbetet, minskade från 39 till 16 procent mellan 2005 och 2015. Minskningen gäller även på särskilt boende, men inte i samma omfattning (Szebehely m.fl., 2017). Ett minskat handlingsutrymme kan försvåra för personalen att lyssna in och vara lyhörda för de äldres behov. Däremot är det inte försvarbart att lägga hela ansvaret på den enskilde anställda eftersom det kan finnas begränsningar för att tillgodose äldre personers existentiella behov i vårdkontexten eller organisationen. Istället behövs stödjande strukturer i organisationen. En viktig sådan stödjande struktur är ledarskapet. Det gäller inte minst i samband med implementering av nya arbetssätt. Moore med flera (2017) fann att hinder för att implementera exempelvis personcentrerad vård i olika vårdkontexter var traditioner, rutiner och stereotypiska attityder medan ledarskap och en öppensinnad attityd istället underlättade införandet. Därför är det viktigt att planera, förankra och anpassa en intervention till den aktuella vårdkontexten och verksamheten. Vidare behöver det finns utrymme för gruppreflektion och gemensamma visioner, ledare behöver ha klart för sig sin roll, sitt ansvar och ha mandat att genomföra förändringen om förändringen ska bli hållbar (Augustsson, Törnquist \& Hasson, 2013). Allt detta är viktigt vid planering av en intervention av personcentrerad vård där systematiskt stöd till vårdpersonal i att samtala med äldre om existentiella frågor är en central del. 


\section{SLUTSATSER}

Utifrån denna avhandling kan följande slutsatser dras:

- Det är av stor betydelse att stödja vårdpersonals och volontärers vilja att skapa meningsfulla relationer som grund för existentiella samtal. Samtidigt är det viktigt att uppmärksamma deras osäkerhet och rädsla att möta existentiell ensamhet och samtala om existentiella frågor. För att stödja såväl personal som volontärer behöves möjlighet att reflektera i grupp för att stödja lärande, både för den enskilda individen och för gruppen.

- Tid och utrymme är en förutsättning för att vårdpersonal och volontärer ska kunna vara närvarande $\mathrm{i}$ mötet och möta existentiell ensamhet och existentiella frågor, exempelvis möjligheten till meningsfulla samtal om såväl livet som döden.

- För att kunna möta den äldres personens existentiella behov krävs inte bara en förmåga att samtala, det krävs även en förmåga att kunna lyssna och en lyhördhet för det som sägs, men även för det som inte sägs.

- Den roll som volontärer har som medmänniskor kan ge en större frihet och handlingsutrymme, medan rollen som professionell ibland kan vara begränsande i relation till existentiella frågor. Det är därför viktigt att se volontärer som ett viktigt komplement i vården av äldre personer.

- För att våga samtala om existentiella frågor behövs det ett systematiskt och strukturerat stöd som organiseras av enhetschefer i samarbete med sjuksköterskor. Ett systematiskt och strukturerat stöd till såväl vårdpersonal som till volontärer är av betydelse och kan ge möjlighet att dela erfarenheter.

- Vårdkontexten har betydelse för hur vårdpersonal uppfattar och möter existentiell ensamhet. Det stöd som ges för att möta existentiella frågor skiljer sig även mellan olika vårdkontexter. När en intervention ska planeras och genomföras behöver den alltså anpassas till den aktuella kontexten och till den aktuella verksamhetens förutsättningar. 


\section{KLINISKA IMPLIKATIONER}

De kliniska implikationerna av avhandlingens resultat kan ses i ljuset av personcentrerad vård och det ramverk som McCormack and McCance (2017) har utvecklat. Ramverket som främst har använts inom vården av äldre personer har fem huvudkomponenter som beskriver förutsättningar för en personcentrerad vård: ett samhällsperspektiv, förutsättningar för personcentrerad vård, vårdandets sammanhang, personcentrerade processer och personcentrerade resultat. Samhällsperspektivet omfattar bland annat attityder och normer, vårdens styrning och tillgång till kompetens som påverkar hur vården organiseras. Förutsättningarna omfattar personalens egenskaper, hängivenhet, självkännedom, kompetens (både professionell och social) och medvetenhet om sina egna värderingar, vårdandets sammanhang handlar om möjligheterna till delat beslutsfattande, samarbete mellan olika professioner, en stödjande organisation, nytänkande och förändringsbenägenhet samt en stödjande fysisk miljö, medan de personcentrerade processerna poängterar vikten av att utgå från den äldre personens värderingar, att ha ett genuint engagemang, delat beslutsfattande, en medveten närvaro och holistisk omvårdnad. Slutligen handlar de personcentrerade resultaten om att vården ska leda till en positiv upplevelse av vården, involvering, en känsla av välbefinnande samt att vårdkulturen är helande.

När det gäller förutsättningarna för en personcentrerad vård visar avhandlingens resultat att såväl personal som volontärer känner osäkerhet i att möta och hantera existentiella funderingar hos äldre personer. För att de ska kunna utveckla sin kompetens och självkännedom och bli medvetna om sina värderingar är det viktigt med möjligheter till kontinuerlig reflektion och systematiskt stöd. Resultatet visar även att det finns ett kunskapsbehov när det gäller olika sorters ensamheter, vad existentiell ensamhet är och hur det kan ge sig till uttryck. Denna kunskap är viktigt för att kunna uppmärksamma och möta äldre personers existentiella behov och funderingar. När det gäller vårdandets sammanhang visar resultatet att personalen behöver ges möjligheter att skapa meningsfulla relationer för att kunna möta existentiella frågor. Enhetschefer inom vård och omsorg har en central roll för att ge personalen handlingsutrymme i vardagen, $i$ en stödjande organisation där enhetschefer och sjuksköterskor samarbetar och leder verksamheten. De har olika 
ledarroller, men kan tillsammans utveckla vården och vara ett stöd till personalen. Vårdandets sammanhang är även relaterat till de kontextuella förutsättningarna. Resultatet visar att vårdkontexten har betydelse och att det är viktigt att i det stöd som ges, ta hänsyn till de förutsättningar som finns. I de personcentrerade processerna poängteras vikten av att utgå från den äldre personens värderingar. Resultatet visade att både personal och volontärer strävade efter att vara lyhörda för den äldre personens behov. Men de djupare, existentiella samtalen kräver inte bara att personal och volontärer känner sig säkra i att möta existentiella frågor, det kräver även att den andre är redo att prata om eller på andra sätt uttrycka dem. För att möta den äldre personen i ett personcentrerat möte, behöver de alltså även utgå från den äldres värderingar och ha ett genuint engagemang och en medveten närvaro. Målet är alltså största möjliga välbefinnande för den äldre personens, men även för vårdpersonalen för att vårdkulturen ska upplevas som helande (personcentrerat resultat).

När det gäller samhällsperspektivet som på ett sätt kan anses som överordnat, är det av vikt att chefer i vård och omsorg, företrädare i volontärorganisationer och politiker på olika nivåer har kunskaper om vilken betydelse prioriteringen av resurser kan medföra för vårdpersonalens möjligheter att ge en så god omvårdnad som möjligt. Det är även viktigt att diskutera hur volontärer som medmänniskor i ännu högre grad kan vara ett komplement till vårdpersonalen. Dessa fem komponenterna i McCormack och McCances (2017) ramverk har var för sig, och tillsammans, betydelse för personcentrerad vård. Det innebär att enskilda insatser inte är tillräckliga för en hållbar förbättring utan att förändringen behöver ske på flera olika nivåer. 


\section{FRAMTIDA FORSKNING}

Även om avhandlingen har gett svar på många forskningsfrågor, har det uppstått nya längs med vägen. Avhandlingens resultat kan utgöra en viktig grund för utvecklingen av kommande interventioner som bland annat riktar sig till vårdpersonal. Följande aspekter är väsentliga att ta hänsyn till när det gäller utformningen av interventioner i syfte att stödja mötet med äldre personer som upplever existentiell ensamhet:

- Det behövs mer än bara en förmåga att samtala för att möta existentiell ensamhet och existentiella frågor. Det behövs en förståelse för verbal och icke-verbal kommunikation samt när det ena eller det andra är lämpligast. Därför behöver en intervention i syfte att stödja vårdpersonal innehålla olika komponenter för att kunna möta den äldre personens behov såsom träning $\mathrm{i}$ att samtala och lyssna, men även i metoder där de kan möta äldre personer på andra sätt, exempelvis genom fysisk beröring.

- Resultatet visade på vårdkontextens betydelse för personalens uppfattning om existentiell ensamhet, men även för deras möjligheter att möta existentiella frågor och möjligheten till stöd. En intervention behöver alltså kontextanpassas utifrån den aktuella verksamhetens förutsättningar.

- Det är viktigt att se volontärer som ett komplement till vårdpersonal. En viktig interventionskomponent skulle kunna vara att mer systematiskt involvera volontärer i vården av äldre personer.

- Enhetschefer är centrala för möjligheten att utveckla och förbättra vården. För att en intervention ska vara hållbar behöver ledarna involveras och ha mandat att påverka.

Det behövs ytterligare kunskap om enhetschefers respektive sjuksköterskors syn på stöd till personal och synen på varandras roller. Enhetschefer och sjuksköterskor inom vård och omsorg har två olika ledarroller och ett samarbete är centralt för en 
äldrevård av god kvalitet. Vi saknar även kunskap om deras enhetschefers syn på att införa systematiskt stöd till personal samt vad som krävs för ett skapa ett klimat som främjar existentiella samtal. Avhandlingens resultat visade även att vårdpersonal och volontärer har olika förutsättningar, där volontärer kan bidra genom att vara medmänniskor. Vi saknar dock kunskap om äldre personers erfarenheter och vad det betyder för dem att möta volontärer. Slutligen vore det värdefullt att undersöka språkets betydelse för att möta, förstå och samtala om existentiella frågor och ytterligare studier om vilken betydelse andra former av kommunikation kan ha inom vården till äldre personer. 


\section{SUMMARY IN ENGLISH}

\section{EXISTENTIAL LONELINESS AMONG FRAIL OLDER PERSONS Professionals' and volunteers' experiences and need for support}

\section{Background}

Existential loneliness is a part of being human that is little understood in healthcare, but to provide good care for older people, professionals must be able to address their existential concerns. Regardless of one's age, having existential needs and thoughts is part of being human. Professionals encounter and care for older people in most care contexts and therefore must be prepared to address their existential needs, alongside physical, psychological, and social needs. Addressing existential loneliness and existential issues can be challenging for professionals and is often not prioritised in times of austerity. Another challenge is the increasing proportion of older people worldwide, challenging society and the healthcare sector to develop new solutions, for example, solutions involving volunteers, especially to combat loneliness among older people. Yet we know little about volunteers' experience of encountering older people's loneliness in general and existential loneliness in particular. Such knowledge is important in order to develop high-quality volunteering. If existential needs are not met or addressed, a feeling of existential loneliness may arise among the cared-for older persons. Whether professionals and volunteers need support and, if so, what kind are important questions to answer if we are to provide adequate support. This thesis is part of the LONE study, exploring existential loneliness among frail older people based on the perspectives of the older people themselves, their significant others, healthcare professionals, family care advisors, volunteers, and first-line managers, and on a review of medical records in palliative care regarding existential aspects. Frail older people were defined as those aged $\geq 75$ years receiving long-term care from formal caregivers provided by the municipality or county council.

\section{Aim and methods}

The overall aim of the thesis was to explore healthcare professionals' and volunteers' experiences of encountering older persons' existential loneliness, the significance of the care context, and first-line managers' view of support. This thesis is based on four 
studies: three were qualitative with a descriptive design (studies I-III) and the fourth was quantitative with a cross-sectional design (Study IV). The data collection for studies I and II was based on focus group interviews with healthcare professionals (i.e., nurse assistant, registered nurse, physician, occupational therapist, physiotherapist, social counsellor, and social worker) in six different care contexts. The data collection for Study III was based on focus group interviews and individual interviews with volunteers from four organisations. Study IV was based on a questionnaire sent to first-line managers in home care and residential care, examining their views of support for staff and volunteers encountering existential issues among older persons.

\section{Findings}

The findings of Study I indicated that healthcare professionals experienced existential loneliness among older people in various ways and situations related to ageing, illness, and end of life. The professionals' stories about encountering older persons' existential loneliness revealed that they often felt insecure about how to talk about existential issues. They also felt inadequate and frustrated when encountering barriers such as the older person's bodily limitations, demands and needs (perceived as insatiable), personal privacy, or fear and difficulty in encountering existential issues. Study II was a multiple case study of the care contexts of home care, residential care, hospital care, and palliative care. The findings indicated that the care context matters regarding professionals' views and interpretations of the origin of existential loneliness. In home care and residential care, these views and interpretations concerned life, the present, and the past. In hospital and palliative care, existential loneliness mainly concerned the older person's forthcoming death. Professionals considered creating relationships an important part of their role in all care contexts, although the meanings, purposes, and conditions of these relationships differed (Study II). Study III showed that being a volunteer meant being a fellow human being, alleviating others' and one's own loneliness. Becoming a volunteer was a way of finding meaning, and volunteering made the volunteers feel rewarded and simultaneously emotionally challenged. Encountering loneliness, including existential loneliness, required sensitivity to others' needs for closeness and distance. The findings of Study IV, based on a questionnaire, indicated that $88 \%$ of the firstline managers found that older persons sometimes or often expressed existential loneliness. They also reported that staff insecurity was the major obstacle to talking about existential issues with the older persons. Support was provided in the form of structured reflection, but provision of systematic supervision was reported by only $6 \%$ of front-line managers. The managers reported that most support was provided by 
themselves or by registered nurses. Almost half of the managers (44\%) reported that, at their units, volunteers were engaged in activities such as everyday conversations and/or music/entertainment. In addition, they also reported a desire for volunteers to be more involved in both everyday and existential conversations.

\section{Discussion}

This thesis identified healthcare professionals' insecurity and fear of talking about existential issues. Some volunteers were also insecure, while others described themselves more as fellow human beings and were more comfortable. Although both professionals and volunteers focused on the relationship with the older person, there were several barriers to having conversations about existential issues. The barriers identified included the physical limitations of the older person (e.g., difficulties expressing themselves and cognitive impairment) and the professionals' perception that the older people themselves were insecure and afraid to talk about existential issues. However, the managers stated that cognitive impairment and aphasia were greater obstacles to conversations about existential issues than were older people's uncertainty and unwillingness to discuss these issues. The professionals found that older people often sought physical closeness, for example, by reaching for a hand to hold, to feel the presence of another person and as a sign of existential loneliness. Soft tissue massage could be a way to alleviate existential loneliness when words were insufficient or there were other difficulties communicating verbally. The context in which care is provided and the framing and orientation of the care have a bearing on how healthcare professionals perceive existential loneliness. In addition, the results indicated that, depending on whether the care was given in the older person's home or at an institution, different conditions prevailed. In palliative care, professionals were offered regular clinical supervision and organised meetings for support, while no organised and regular support and/or supervision were offered in home, residential, or hospital care. Lack of time and continuity were other constraints, so it is important to adapt and tailor support to the specific care context.

One of the greatest challenges facing staff in the care of older people is to address older people's existential concerns about life and death. Staff insecurity and fear were mainly about how to approach and respond to older people's existential thoughts. In contrast, the volunteers could allow themselves to "just be" to a much greater extent, simply listening and being fellow human beings. This indicates that the professional role can sometimes be a limitation in relation to existential issues and conversations in which the volunteer role gives greater freedom of action. If no support is provided 
or action is taken to increase professionals' confidence in encountering existential issues, there is a risk that older persons will be left alone with their existential issues. Studies show that systematic and structured reflection can improve understanding of the older person's situation and what is meaningful to that person, suggesting that systematic and structured support for healthcare professionals and volunteers is important. However, this would require systematic support from managers, so that the work is organised to provide opportunities for existential conversations.

\section{Conclusion}

In conclusion, one of the most important findings of this thesis was the insecurity of the professionals and their fear of discussing existential issues. This was revealed in the interviews with the professionals and confirmed by the first-line managers. According to professionals and volunteers, the relationship with the older person was important when encountering existential issues. This thesis demonstrates the importance of helping professionals focus on existential issues about life and death and of the potential of volunteers as an important complement in the care of older people.

\section{Clinical implications}

The clinical implications of the findings are that it is important to recognise healthcare professionals' insecurity and fear when encountering older people's existential loneliness and having existential conversations with them. The significance of the relationship of the professionals and volunteers with the older persons also needs to be highlighted, as does the influence of a trusting relationship on existential conversations. However, we need to know how older persons themselves experience encounters with volunteers, and what volunteers believe that they can contribute. Since first-line managers are responsible for supporting their staff, more knowledge is needed of managers' own experience of obstacles to providing systematic and structured support to staff and to creating space in everyday care for existential conversations. 


\section{TACK}

Ett särskilt stort och varmt tack vill jag ägna alla de personer som deltagit i intervjuer och besvarat enkäter i mina studier. Tack till all vårdpersonal som berättat och generöst delat med sig av sina erfarenheter till oss forskare och till varandra. Tack till alla kontaktpersoner som hjälpt mig att koordinera fokusgruppsintervjuerna och deltagit $\mathrm{i}$ telefonintervjuer. Tack också till alla volontärer som deltagit $\mathrm{i}$ både fokusgruppsintervjuer och individuella intervjuer. Några av er har jag besökt i era respektive verksamhetslokaler, andra har varit på min arbetsplats och några av er har jag intervjuat i era hem. Ni har gjort intryck på mig. Tack även till alla bussiga och hjälpsamma kontaktpersoner i de olika volontärorganisationerna. Ett varmt och innerligt tack för att ni har delat med er av tankar och erfarenheter. Till alla enhetschefer inom vård och omsorg som avsatt tid att besvara den enkät som skickades till er - stort tack. Det har varit en viktig pusselbit.

Till referensgruppen som varit knuten till LONE-studien. Ann-Margreth Albin, Bengt Gustafsson, Mogens Hey, Lisbeth Mattsson, Anita Olsson och Eva Wiman. Ni har följt oss genom åren och bidragit med värdefulla och kloka tankar som varit till hjälp för mig i mitt avhandlingsarbete. Tusen tack för goda samtal.

Till mina tre fantastiska handledare, Anna-Karin Edberg, Kerstin Blomqvist och Margareta Rämgård. I mina ögon har ni varit mina supporters, påhejare och välbehövliga kritiker. TACK.

Anna-Karin Edberg, min huvudhandledare. Jag är otroligt tacksam för all din hjälp och uppmuntran under min doktorandtid. Trots din oerhörda snabbhet och skärpa i tanke och handling så har du har en lyhördhet och förmåga att känna in när det är tid för eftertänksamhet, men också för samtal på ett mellanmänskligt plan. Det är en värdefull egenskap hos en handledare. Ordning och struktur har jag fătt från dig. Det skapar trygghet. Du har låtit mig tänka högt och brett i vissa skeden och i andra skeden tyglat mina tankar för att hålla mig på banan när det har behövts. Du har också en förmåga att se lösningar när något inte går som det är tänkt och få en doktorand att känna hopp. Du har låtit mig få göra mycket vilket jag är glad för, men tålmodigt sagt 
nej när det har behövts. Det är jag också glad för. Trots välbehövliga korrigeringar av mina texter har dina konstruktiva kommentarer alltid innehållit uppmuntran och glada hejarop.

Kerstin Blomqvist, min biträdande handledare. Det var du som visade mig vägen in $\mathrm{i}$ forskning och den som fick mig att tänka och tro att det var en möjlig väg att gå. Handledarrelationen började redan när jag skrev min magisteruppsats, så du har funnits i min värld under många år. Tänk så många mil vi har åkt runt i Skåne för datainsamling. Du brukade säga att vi var handelsresande i fokusgrupper. Vilka fina samtal vi har haft, om livet och andra viktiga ting. Du har varit en stor inspiratör för mig under många år. Du är en otrolig pedagog och har hjälpt mig att förstå betydelsen av att analysarbete tar tid, och behöver ta tid. Du har även en fantastisk förmåga att se en text och med några få ord göra att den får en helt annan skärpa. Jag har förundrats över det många gånger. Tack också för alla gånger jag har fătt låna ert gästrum när det av olika anledningar varit för sent för mig att åka hem till Viken.

Margareta Rämgård, min biträdande handledare. Du och jag har haft samarbete sedan flera år och som började redan i ett tidigare forskningsprojekt. Eftersom vi inte arbetar på samma lärosäte ses vi av naturliga skäl inte lika ofta. Inte desto mindre har vi haft många och goda samtal som jag har uppskattat. Dina kloka och skarpa synpunkter och reflektioner har ofta bidragit med en annan vinkel som har haft betydelse för mig på olika sätt, både i studierna och på ett personligt plan. Det var du som förmedlade kontakten till Christine Milligan, så att jag fick möjlighet att vistas vid Centre for Ageing Research, Lancaster University. Tack så mycket. Jag har varit glad för våra samtal och hoppas att de fortsätter.

Till alla forskare i LONE studien - ett stort och varmt tack för att jag har fått ta del av kunskap och erfarenheter. Inte minst alla diskussioner som förts under projektets gång. Det har varit oerhört värdefullt att som doktorand få vara en del av ett sådant sammanhang och inte minst för mitt avhandlingsarbetes skull. Ett särskilt tack till Anna-Karin Edberg och Ingrid Bolmsjö som projektledare och som startade upp projektet. Så ett stort tack till alla, Kerstin Blomqvist, Ingela Beck, Margareta Rämgård, Birgit Rasmussen, Ingalill Rahm Hallberg, Christine Kumlien, Marina Sjöberg, Helena Larsson och Jonas Olofsson. Tack också till Magdalena Andersson som var med i början av projektet. 
Till mina alldeles speciella musketörskompisar Helena Larsson och Marina Sjöberg. Vi har kämpat tillsammans, och var för sig, med våra doktorandprojekt inom LONEstudien. Vi har hållit ett flertal presentationer tillsammans och åkt på konferenser i Sverige, men också till San Francisco och Leuven. Vi har delat många goda skratt och också ovisshet och vånda. Allt det som ingår i en doktorandtillvaro. Det har varit en förmån att göra det tillsammans med er. Vi har alltid varandra.

Till alla finansiärer som möjliggjorde mina doktorandstudier. Till Forskningsplattformen Hälsa i Samverkan och för finansiering av min doktorandtjänst. Det är jag tacksam, glad och stolt över. Tack även till andra finansiärer som bidragit till att studierna har kunnat genomföras. Crafoordska stiftelsen, Greta och Johan Kocks stiftelse, Gyllenstiernska Krapperupsstiftelsen och Vårdalstiftelsen.

Tack också till SWEAH, Nationella forskarskolan om åldrande och hälsa. Jag har varit glad och stolt att vara med i det sammanhanget och för alla trevliga doktoranddagar, kurser och nätverkande i samband med konferenser. Ett särskilt tack till Susanne Iwarsson, Maria Haak och Charlotte Löfqvist. Till Stina Elfverson, tack för din servicekänsla, snabbhet och vilja att göra det trevligt för oss doktorander. Det var också tack vare medel från SWEAH som gjorde min forskningsvistelse vid Lancaster University i England möjlig.

Till Forskningsplattformen Hälsa i samverkan och forskningschef Albert Westergren, till forskningsassistent Therese Martinsson och senare Fanny Sundqvist. Tack för all support och att ni tänker på doktorandernas välmående. Tack till alla inblandade vid doktorandseminarierna. Först var det Anna-Karin Edberg, tidigare forskningschef som ledde seminarierna för oss doktorander och senare Albert Westergren och Kerstin Blomqvist. Seminarierna är ett lysande exempel på att det är doktorandernas lärande som är i fokus och att vi får vara delaktiga i de förändringar som sker. Tack alla doktorander som under dessa fyra år har varit med, några har gått före och några fortsätter ett tag till. Vi ses igen, fast i ett annat sammanhang.

Till alla vid Institutionen för vårdvetenskap vid Malmö Universitet, där jag som doktorand har varit inskriven. Tack för att jag har fătt vara en del av ert sammanhang och få ta del av all spännande forskning som genomförs hos er. Stort tack Christine Kumlien som har lett doktorandseminarierna och alla andra seniora forskare som på olika sätt har bidragit till vårt lärande vid dessa seminarier. Ett särskilt tack till Elisabeth Carlson som med ditt positiva och pedagogiska sätt bidragit till ett gott 
klimat. Tack till alla doktorander som jag träffat under dessa år. Jag är glad för de många givande diskussioner, men också alla de fina samtalen om livet som doktorand vid våra doktorandluncher. Fortsätt med det förändringsarbete som ni har påbörjat och all lycka till med era fortsatta doktorandstudier. Tack också till Jonna Ausfelt, forskningsadministratör för all hjälp.

Tack för administrativt stöd och hjälp från biblioteket vid Malmö Universitet och Högskolan Kristianstad. Det har varit guld värt många gånger. Tack även till Sophia Lundquist för språkgranskning av ramberättelsen.

Till min familj. Min man Björn, min bäste vän här i livet. Tack för att du lät mig göra detta fastän det så många gånger har tagit av vår tid. Trots det har du alltid varit snäll och hjälpt mig för att det ska flyta på så bra som möjligt. Våra kloka döttrar Ebba och Elin. Jag har många gånger förundrats över er klokskap. Ni är en stor glädje i mitt liv. Tack alla andra i min familj, min pappa Lars och min kära syster Anna för att ni alltid frågar och undrar hur det går. Om min mamma Greta hade levt idag hade hon varit glad att jag gjorde detta, det vet jag. Tack också till mina fina svärföräldrar Ruth och Sture, och alla släktingar och vänner som alltid visar intresse och tror på mig. 


\section{REFERENSER}

Abley, C., Bond, J. \& Robinson, L. (2011). Improving Interprofessional practice for vulnerable older people: gaining a better understanding of vulnerability. Journal of Interprofessional Care, 25, $359-365$.

Alftberg, Å. (2012). Vad är det att åldras? En etnologisk studie av åldrande, kropp och materialitet. (Doktorsavhandling, Lunds universitet, Institutionen för kulturvetenskaper).

Altman, I. \& Low, S. M. (1992). Place attachment. New York: Springer.

Andersson, M., Hallberg, I. R. \& Edberg, A. K. (2008). Old people receiving municipal care, their experiences of what constitutes a good life in the last phase of life. International Journal of Nursing Studies, 45(6), 818.

Andersson, B. \& Öhlén, J. (2005). Being a hospice volunteer. Palliative Medicine, 19(8), 602-609.

Applebaum, F. (1978). Loneliness: A taxonomy and psychodynamic view. Clinical Social Work Journal, 6 (1), 13-20.

Arlebrink, J. (2012). Existentiella frågor - inom vård och omsorg. Lund: Studentlitteratur.

Augustsson, H., Törnquist, A. \& Hasson, H. (2013). Challenges in transferring individual learning to organizational learning in the residential care of older people. Journal of Health Organization and Management, 27(3), 390-408.

Baltes, P. \& Smith, J. (2003). New Frontiers in the Future of Aging: From Successful Aging of the Young Old to the Dilemmas of the Fourth Age. Gerontology, 49, 123-135.

Banerjee, S. C., Manna, R., Coyle, N., Johnson Shen, M., Pehrson, C., Zaider, T., . . Bylund, C. L. (2016). Oncology nurses' communication challenges with patients and families: A qualitative study. Nurse Education in Practice, 16(1), 193-201.

Bassett, L., Bingley, A. F. \& Brearley, S. G. (2018). Silence as an element of care: A metaethnographic review of professional caregivers' experience in clinical and pastoral settings. Palliative Medicine, 32, 185-194.

Baxter, R., Sandman, P.-O., Björk, S. \& Lood, Q. \& Edvardsson, D. (2019). 1lluminating Meanings of Thriving for Persons Living in Nursing Homes. The Gerontologist. doi: org/10.1093/geront/gnz142

Beauchamp, T. \& Childress, J. F. (2013). Principles of biomedical ethics. New York: Oxford University Press.

Beck, I. (2013). Att fokusera på "varandet" i en värld av görande: Stöd till personal i ett palliativt förhållningssätt vid vård- och omsorgsboende för äldre. (Doktorsavhandling, Lunds universitet, Institutionen för hälsa, vård och samhälle). 
Beck, I., Jakobsson, U. \& Edberg, A.-K. (2014). Applying a palliative care approach in residential care: effects on nurse assistants' experiences of care provision and caring climate. Scandinavian Journal of Caring Sciences, 28(4), 830.

Beck, I., Törnquist, A. \& Edberg, A.-K. (2014). Nurse assistants' experience of an intervention focused on a palliative care approach for older people in residential care: Experience of an intervention focused on palliative care. International Journal of Older People Nursing, 9(2), 140150.

Benktson, B-E. (1976). Gränssituationerna: Frågor om livets mening i existensfilosofisk belysning. Lund: Liber Läromedel.

Bodner, E. (2009). On the origins of ageism among older and younger adults. International Psychogeriatrics, 21(6), 1003-1014.

Bolmsjö, I., Sandman, L. \& Andersson, E. (2006). Everyday ethics in the care of elderly people. Nursing Ethics, 13(3), 249-263.

Bolmsjö, I., Tengland, A. \& Rämgård, M. (2019). Existential loneliness: An attempt at an analysis of the concept and the phenomenon. Nursing Ethics, 26(5) 1310-1325

Brinkmann, S. \& Kvale, S. (2015). InterViews: learning the craft of qualitative research interviewing. Los Angeles: Sage Publications.

Broström, M. (2014). Äldre människors föreställningar om den egna framtiden, döendet och döden. (Doktorsavhandling, Linköpings universitet, Institutionen för samhälls- och välfärdsstudier).

Browall, M., Koinberg, I., Falk, H. \& Wijk, H. (2013). Patients' experience of important factors in the healthcare environment in oncology care. International Journal of Qualitative Studies on Health and Well-being, 8(1), 20870-20810.

Browall, M., Melin-Johansson, C., Strang, S., Danielson, E. \& Henoch, I. (2010). Health care staff's opinions about existential issues among patients with cancer. Palliative and Supportive Care, 8(1), 59-68.

Buber, M. (1994). Jag och du. Ludvika: Dualis Förlag.

Buber, M. (1995). Det mellanmänskliga. Ludvika: Dualis.

Carlson, E., Rämgård, M., Bolmsjö, I. \& Bengtsson, M. (2014). Registered nurses’ perceptions of their professional work in nursing homes and home-based care: A focus group study. International Journal of Nursing Studies, 51(5), 761-767.

Claxton-Oldfield, S. (2015). Hospice palliative care volunteers: The benefits for patients, family caregivers, and the volunteers. Palliative \& Supportive Care, 13(3), 809-813.

Cohen-Mansfield, J., Hazan, H., Lerman, Y. \& Shalom, V. (2015). Correlates and predictors of loneliness in older-adults: a review of quantitative results informed by qualitative insights. International Psychogeriatrics, 1-20.

Creswell, J. W. (2007). Qualitative inquiry \& research design: Choosing among five approaches. Thousand Oaks: SAGE Publications, Inc. 
Cronfalk, B. S., Strang, P., Ternestedt, B. M. \& Friedrichsen, M. (2009). The existential experiences of receiving soft tissue massage in palliative home care-an intervention. Supportive Care in Cancer, 17(9), 1203-1211.

Dahlberg, K., Stolt, C.-M. \& Dahlberg, H. (2015). Ensamheter: en utforskande brevväxling. Stockholm: Liber.

Datainspektionen (u.å.) The General Data Protection Regulation (GDPR). Hämtad 20-01-01 från https://www.datainspektionen.se/other-lang/in-english/the-general-data-protection-regulationgdpr/

van Deurzen, E. (1998). Det existentiella samtalet: Ett perspektiv för psykoterapin. Stockholm: Natur och Kultur.

van Deurzen, E. (2012). Existential counselling \& psychotherapy in practice (3 uppl.). London: SAGE.

Dillman, D. A., Smyth, J. D. \& Christian, L. M. (2014). Internet, phone, mail, and mixed-mode surveys: the tailored design method. Hoboken, New Jersey: Wiley.

Dodd, S., Hill, M., Ockenden, N., Algorta, G. P., Payne, S., Preston, N. \& Walshe, C. (2018). 'Being with' or 'doing for'? How the role of an end-of-life volunteer befriender can impact patient wellbeing: interviews from a multiple qualitative case study (ELSA). Supportive Care in Cancer, 26(9), 3163-3172.

Ebrahimi, Z., Wilhelmson, K., Eklund, K., Dea Moore, C. \& Jakobsson, A. (2013). Health despite frailty: Exploring influences on frail older adults' experiences of health. Geriatric Nursing, 34, 289-294.

Edberg, A. K. \& Bolmsjö, I. (2019). Exploring Existential Loneliness Among Frail Older People as a Basis for an Intervention: Protocol for the Development Phase of the LONE Study. RR210.2196/1307, JMIR Research Protocols, 14;8(8):e13607.

Edvardsson, D. Varrailhon, P. \& Edvardsson, K. (2014). Promoting Person-Centeredness in LongTerm Care. Journal of Gerontological Nursing, 40(4), 46-53.

Ellström, E. (2012). Managerial support for learning at work: a qualitative study of first-line managers in elder care. Leadership in Health Services, 25(4), 273-287.

Engström, G. \& Fagerberg, I. (2011). Attitudes towards older people among Swedish health care professionals working in elder care. Nursing Reports, $1: \mathrm{e} 2$.

Erikson, E. H. \& Erikson, J. (1997). The life cycle completed: Extended version with new chapters on the ninth stage of development. New York: W.W. Norton \& Company.

Ernsth Bravell, M. (2013). Gerontologi - vad är det? I M. Ernsth Bravell (Red.), Äldre och åldrande. Grundbok i gerontologi (s. 19-42). Malmö: Gleerups Utbildning AB.

Ernsth Bravell, M. (2017). Den förändrade kroppen. I Blomqvist, K., Edberg, A-K., Ernsth Bravell, M. \& Wijk, H (Red.). Omvårdnad och äldre (s. 201-216). Lund: Studentlitteratur.

Ettema, E., Derksen, L. \& van Leeuwen, E. (2010). Existential loneliness and end of life care: A systematic review. Theoretical Medicine and Bioethics, 31(2), 141-169. 
Fillit, H. \& Butler, R. (2009). The frailty identity crisis. Journal of American Geriatrics Society, 57(2), 348-352.

Finfgeld-Connet, D. (2008). Meta-synthesis of caring in nursing. Journal of Clinical Nursing, 17(2), 196-204.

Finnbakk, E., Skovdahl, K., Störe Blix, E. \& Fagerström, L. (2012). Top-level managers' and politicians' worries about future care for older people with complex and acute illnesses - a Nordic study. International Journal of Older People Nursing, 7(2), 163-172.

Frankl, V. (2006). Livet måste ha mening. Erfarenheter från koncentrationslägren: logoterapins grundbegrepp. Stockholm: Natur och Kultur.

Franklin, L-L., Ternestedt, B-M. \& Nordenfelt, L. (2006). Views on dignity of elderly nursing home residents. Nursing Ethics, 13(2), 130-146.

Friedrichsen, M. (2013). Språkets och samtalets betydelse. I B. Andershed, B-M. Ternestedt \& C. Håkanson (Red.), Palliativ vård. Begrepp \& perspektiv i teori och praktik (s. 431-442). Lund: Studentlitteratur.

Graneheim, U. H. \& Lundman, B. (2004). Qualitative content analysis in nursing research: concepts, procedures and measures to achieve trustworthiness. Nurse Education Today, 24(2), 105-112.

Graneheim, U. H. \& Lundman, B. (2010). Experiences of loneliness among the very old: The Umeå 85+ project. Ageing \& Mental Health, 14(4), 433-438.

Greenwood, D. E., Gordon, C., Pavlou, C. \& Bolton, J. V. (2018). Paradoxical and powerful: Volunteers' experiences of befriending people with dementia. Dementia, 17(7), 821-839.

Guba, E. G. (1981). Criteria for assessing the trustworthiness of naturalistic inquiry. Educational Communication and Technology, 29(2), 75-91.

Harnett, T. (2010). The trivial matters. Everyday power in Swedish Elder Care. (Doktorsavhandling, Jönköping University, Hälsohögskolan).

Hedman, M., Häggström, E., Mamhidir, A.-G. \& Pöder, U. (2019). Caring in nursing homes to promote autonomy and participation. Nursing Ethics, 26(1), 280-292.

Hemberg, J., Nyqvist, F. \& Näsman, M. (2019). "Homeless in life" - loneliness experienced as existential suffering by older adults living at home: a caring science perspective. Scandinavian Journal of Caring Sciences, 33(2), 446-456.

Hjelmblink, F., Bernsten, C. B., Uvhagen, H., Kunkel, S. \& Holmström, I. K. (2007). Understanding the meaning of rehabilitation to an aphasic patient through phenomenological analysis - a case study. International Journal of Qualitative Studies on Health and Well-being, 2(2), 93.

Houtepen, R. \& Hendrikx, D. (2003). Nurses and the Virtues of Dealing with Existential Questions in Terminal Palliative Care. Nursing Ethics, 10(4), 377-387.

Hsieh, H. F. \& Shannon, S. E. (2005). Three approaches to qualitative content analysis. Qualitative Health Research, 15(9), 1277-1288.

Hyett, N., Kenny, A. \& Dickson-Swift, V. (2014). Methodology or method? A critical review of qualitative case study reports. International Journal of Qualitative Studies on Health and Wellbeing, 9. 
Håkanson, C., Cronfalk, B. S., Henriksen, E., Norberg, A., Ternestedt, B.-M. \& Sandberg, J. (2014). First-Line Nursing Home Managers in Sweden and their Views on Leadership and Palliative Care. The open nursing journal, 8(1), 71-78.

Jegermalm, M. \& Jeppsson Grassman, E. (2009). Caregiving and Volunteering Among Older People in Sweden - Prevalence and Profiles. Journal of Aging \& Social Policy, 21(4), 352-373.

Jegermalm, M. \& Jeppsson Grassman, E. (2013). Links between informal caregiving and volunteering in Sweden: a 17-year perspective. European Journal of Social Work, 16(2), 205219.

Jenner, H. \& Henriksson, C. (2008). Att leva i sin berättelse - livsberättande som grund för meningsskapande. I D. Stiwne (Red.), Bara detta liv (s. 78-101). Stockholm: Natur och Kultur.

Johnsson, A., Boman, Å., Wagman, P. \& Pennbrant, S. (2018). Voices used by nurses when communicating with patients and relatives in a department of medicine for older people-An ethnographic study. Journal of Clinical Nursing, 27(7-8), e1640-e1650.

Jonkman, L. (2013). Introvert: den tysta revolutionen. Stockholm: Bokförlaget Forum.

Jönsson, B. (2011). När horisonten flyttar sig : att bli gammal i en ny tid. Stockholm: Bromberg.

Kjellström, S. (2012). Forskningsetik. I. M. Henricsson (Red.), Vetenskaplig teori och metod: Från idé till examination inom omvårdnad (s. 69-92). Lund: Studentlitteratur.

Krueger, R. A. \& Casey, M. A. (2015). Focus groups : a practical guide for applied research (5 uppl.). Thousand Oaks: Sage.

Kydd, A. (2008). The patient experience of being a delayed discharge. Journal of Nursing Management, 16, 121-126.

Larsson, H., Edberg, A. K., Bolmsjö, I. \& Rämgård, M. (2019). Contrasts in older persons' experiences and significant others' perceptions of existential loneliness. Nursing Ethics, 26(6) $1623-1637$.

Larsson, K. \& Thorslund, M. (2006). Old people's health. Scandinavian Journal of Public Health, 34, 185-198.

Lev, S., Wurm, S. \& Ayalon, L. (2018). Origins of ageism at the individual level. I L. Aylon \& Clemens Tesch-Römer (Red.), Contemporary perspectives on Ageism (s. 51-72). Cham: Springer Open.

Lincoln, Y. S. \& Guba, E. G. (1985). Naturalistic inquiry. Beverly Hills: Sage.

Lindahl, L. (2019). Samvaro och samtal om minnen från förr. Göteborg: FoU Väst/Arbetsmarknad och social välfärd.

Lindberg, E. (2014). Tid för vårdande möten. Att vidmakthålla och utveckla vårdandet med patientperspektivet i fokus. (Doktorsavhandling, Linnéuniversitetet, Institutionen för hälso- och vårdvetenskap).

Lindberg, E., Ekebergh, M., Persson, E. \& Hörberg, U. (2015). The importance of existential dimensions in the context of the presence of older patients at team meetings - In the light of Heidegger and Merleau-Ponty's philosophy. Qualitative Studies on Health and Well-being, 10, $1-10$. 
Liu, Y., Norman, I. \& While, A. E. (2013). Nurses' attitudes towards older people: a systematic review. International Journal of Nursing Studies, 50 (9), 1271-1282.

Lloyd, A., Kendall, M., Starr, J. M. \& Murray, S. A. (2016). Physical, social, psychological and existential trajectories of loss and adaptation towards the end of life for older people living with frailty: a serial interview study. BMC Geriatrics, 16(1), 176-115.

Lundin, A., Berg, L-E. \& Hellström Muhli, U. (2013). Feeling existentially touched - A phenomenological notion of the well-being of elderly living in special housing accommodation from perspective of care professionals. International Journal of Qualitative Studies on Health and Well-being, 8, 1-8.

Mansfield, L., Daykin, N., Meads, C., Tomlinson, A., Gray, K., Lane, J. \& Victor, C. (2019). A conceptual review of loneliness across the adult life course $(16+$ years $)$. London: What Works Centre for Wellbeing.

McCormack, B., Dewing, J. \& McCance, T. (2011). Developing person-centred care: Addressing contextual challenges through practice development. The Online Journal of Issues in Nursing, $16(2), 3$.

McCormack, B. \& McCance, T. (2010). Person-centered Nursing: Theory and Practice. Oxford: Wiley-Blackwell.

McCormack, B. \& McCance, T. (2017). Person-centred practice in nursing and health care: theory and practice. Oxford: Wiley Blackwell.

MRC. (2008). Medical Research Council. Developing and Evaluating Complex Interventions: New Guidance. London: Medical Research Council.

Meleis, A., Sawyer, L., Im, E-O., Hilfinger Messias, D. \& Schumacher, K. (2000). Experiencing Transitions: An Emerging Middle-Range Theory. Advances in Nursing Science, 23(1), 12-28.

Merriam, S. B. (2016). Qualitative research: A guide to design and implementation. San Francisco: Jossey-Bass.

Mijuskovic, B. L. (2012). Loneliness in philosophy, psychology and literature. Bloomington: iUniverse Inc.

Minton, M. E., Isaacson, M. J., Varilek, B. M., Stadick, J. L. \& O'Connell-Persaud, S. (2018). A willingness to go there: Nurses and spiritual care. Journal of Clinical Nursing, 27(1-2), 173-181.

Moore, L., Britten, N., Lydahl, D., Naldemirci, Ö., Elam, M. \& Wolf, A. (2017). Barriers and facilitators to the implementation of person-centred care in different healthcare contexts. Scandinavian Journal of Caring Sciences, 31(4), 662-673.

Nicholson, C., Meyer, J., Flatley, M. \& Holman, C. (2013). The experience of living at home with frailty in old age: A psychosocial qualitative study. International Journal of Nursing Studies, 50, $1172-1179$.

Nilsen, P., Wallerstedt, B., Behm, L. \& Ahlström, G. (2018). Towards evidence-based palliative care in nursing homes in Sweden: a qualitative study informed by the organizational readiness to change theory. Implementation Science, 13(1), 1-12. 
Nilsson, M. (2008). Våra äldre: Om konstruktioner av äldre i offentligheten. (Doktorsavhandling, Linköpings universitet, Institutionen för samhälls- och välfärdsstudier).

Nilsson, M., Sarvimäki, A. \& Ekman S-L. (2000). Feeling old: being in a phase of transition in later life. Nursing Inquiry, 7, 41-49.

Norberg, A., Lundman, B., Nygren, B. \& Santamäki Fischer, R. (2012). Transitioner under åldrandet. I A. Norberg, B. Lundman \& R. Santamäki Fischer (Red.), Det goda åldrandet (s. 79119). Lund: Studentlitteratur.

Norell Pejner, M. (2013). The bright side of life. Support in municipal elderly home care. (Doktorsavhandling, Örebro Universitet, Institutionen för hälsovetenskap och medicin).

Nyström, A. (2004). Grunna - en väg till sinnesfrid. I K. Blomqvist \& A-K. Edberg (Red.), Att vara äldre "...man har ju sina krämpor..." (97- 109). Lund: Studentlitteratur.

Nyström, M. (2006). Aphasia - an existential loneliness: A study on the loss of the world of symbols. International Journal of Qualitative Studies on Health and Well-being, 1(1).

Nyström, A-S. (2012). Mellan empati och kritisk granskning. I H. Kalman \& V. Lövgren (Red.), Etiska dilemman: Forskningsdeltagande, samtycke och utsatthet (s. 71-86). Malmö: Gleerups.

Olsson, C., Rydsten, C. \& Blomqvist, K. (2018). Existentiell ensamhet bland äldre personer volontärers uppfattningar. Rapport nr 6/2018. Kristianstad: Kristianstad University Press.

Olsson, L-E., Svedberg, L. \& Jeppsson Grassman, E. (2005). Medborgarnas insatser och engagemang $i$ civilsamhället - några grundläggande uppgifter från en ny befolkningsstudie. Ett regeringsuppdrag till Sköndalsinstitutet. Stockholm: Sköndalsinstitutets forskningsavdelning.

Orrung Wallin, A. (2013). Job satisfaction, strain and stress of conscience among nurse assistants working in residential care for older people. (Doktorsavhandling, Lunds universitet, Institutionen för hälsovetenskaper).

Ozolins, L-L. (2011). Beröringens fenomenologi $i$ vårdsammanhang. (Doktorsavhandling, Linnéuniversitetet, Institutionen för hälso- och vårdvetenskap).

Ozolins, L. L., Hörberg, U. \& Dahlberg, K. (2015). Caring touch - patients' experiences in an anthroposophic clinical context. Scandinavian Journal of Caring Sciences, 29(4), 834-842.

Peplau, L. A. \& Perlman, D. (1982). Loneliness: a source book of current theory, research and therapy. New York: John Whiley \& Sons.

Planalp, S., Trost, M. R. \& Berry, P. H. (2011). Spiritual Feasts: Meaningful Conversations between Hospice Volunteers and Patients. American Journal of Hospice and Palliative Medicine, 28(7), 483-486.

Polit, D. F. \& Beck, C. T. (2012). Nursing research : generating and assessing evidence for nursing practice. 9:e uppl. Philadelphia: Wolters Kluwer.

Ranung, M. \& Åhlfeldt, E. (2018). Att främja psykisk hälsa på kort och lång sikt. Handen: Nestor. Forskning och utveckling för äldre.

Rattan, S. (2006). Theories of biological aging: Genes, proteins, and free radicals. Free Radical Research, 40(12), 1230-1238. 
Regionala Cancercentrum i Samverkan. (2016). Palliativ vård i livets slutskede program. Nationellt vårdprogram. Hämtad 20-03-16 från http://www.cancercentrum.se/samverkan/

Ricœur, P. (2011). Homo capax: texter av Paul Ricoeur om etik och filosofisk antropologi. Göteborg: Daidalos.

Rosenberg, C. (2010). Den existentiella sidan av åldrandet - inifrån. FOU-dokument 2010:6. Malmö: Stadskontoret.

Rowles, G. D. \& Bernard, M. (2013). Environmental gerontology: Making meaningful places in old age. New York: Springer Publishing Company.

Ryan, F., Coughlan, M. \& Cronin, P. (2009). Interviewing in qualitative research: The one-to-one interview. International Journal of Therapy and Rehabilitation, 16(6), 309-314.

Sand, L. \& Strang, P. (2006). Existential loneliness in a palliative home care setting. Journal of Palliative Medicine, 9(6), 1376-1387.

Santamäki Fischer, R., Norberg, A. \& Lundman, B. (2008). Embracing opposites: meanings of growing old as narrated by people aged 85. The International Journal of Aging \& Human Development, 67(3), 259.

Sarvimäki, A. \& Stenbock-Hult, B. (2014). The meaning of vulnerability to older persons. Nursing Ethics, 1-12.

SBU. (2019). Statens beredning för medicinsk utvärdering. Kunskapsläget för bedömning och insatser inom äldreomsorgen. (SBU-rapport 306/2019). Stockholm: Statens beredning för medicinsk utvärdering.

SCB. (2019). Statens statistiska centralbyrå. Hitta statistik. Sverige i siffror. Hämtad 20-02-08 från https://www.scb.se/hitta-statistik/sverige-i-siffror/manniskorna-i-sverige/medellivslangd-isverige/

SCB. (2019). Statens statistiska centralbyrå. Hitta statistik. Sverige i siffror. Hämtad 20-02-08 från https://www.scb.se/hitta-statistik/sverige-i-siffror/manniskorna-i-sverige/doda-i-sverige/

SCB. (2020). Statens statistiska centralbyrå. Hitta statistik. Sverige i siffror. Hämtad 20-02-08 från https://www.scb.se/hitta-statistik/sverige-i-siffror/utbildning-jobb-och-pengar/yrken-i-sverige/

Schreier, M. (2012). Qualitative content analysis in practice. London: SAGE.

Schuster, M. (2006). Profession och existens: en hermeneutisk studie av asymmetri och ömsesidighet i sjuksköterskors möten med svårt sjuka patienter. Göteborg: Daidalos.

Schön, P., Lagergren, M. \& Kåreholt, I. (2016). Rapid decrease in length of stay in institutional care for older people in Sweden between 2006 and 2012: results from a population-based study. Health \& Social Care in the Community, 24(5), 631-638.

Schön Persson, S., Nilsson Lindström, P., Pettersson, P., Nilsson, M. \& Blomqvist, K. (2018). Resources for work-related well-being: A qualitative study about healthcare employees' experiences of relationships at work. Journal of Clinical Nursing, 27(23-24), 4302-4310.

SFS 1990:782. Arkivlag. Stockholm: Regeringskansliet.

SFS 2003:460. Lag om etikprövning av forskning som avser människor. Stockholm: Regeringskansliet. 
SFS 2008:962. Lag om valfrihetssystem. Stockholm: Regeringskansliet.

Shenton, A. K. (2004). Strategies for ensuring trustworthiness in qualitative research projects. Education for Information, 22, 63-75.

Sjöberg, M., Beck, I., Rasmussen, B. H. \& Edberg, A. K. (2018). Being disconnected from life: meanings of existential loneliness as narrated by frail older people. Aging \& Mental Health, 22(10), 1357-1364.

Sjögren, K. (2013). Personcentrerad vård i särskilda boenden för äldre. (Doktorsavhandling, Umeå universitet, Institutionen för omvårdnad).

Skilbeck, J. K., Arthur, A. \& Seymour, J. (2018). Making sense of frailty: An ethnographic study of the experience of older people living with complex health problems. International Journal of Older People Nursing, 13(1), e12172-n/a.

Skovdahl, K., Sörlie, V. \& Kihlgren, M. (2007). Tactile stimulation associated with nursing care to individuals with dementia showing aggressive or restless tendencies: an intervention study in dementia care. International Journal of Older People Nursing, 2(3), 162-170.

Sköndalsinstitutet. (2003). Volontärer - för vem och för vad? (Arbetsrapportserie nr 31). Stockholm: Sköndalsinstitutets forskningsavdelning.

Socialdepartementet. (2012). Uppdrag för att höja kompetensen hos ledare inom äldreomsorgen. Hämtad 20-02-17 från https://www.regeringen.se/

Socialstyrelsen. (2012). Tillståndet och utvecklingen inom hälso- och sjukvård och socialtjänst. Lägesrapport 2012.

Socialstyrelsen. (2016). Din rätt till vård och omsorg - en vägvisare för äldre [Broschyr]. Hämtad från https://www.socialstyrelsen.se/

Socialstyrelsen. (2018). Öppna jämförelser av hemtjänst och särskilt boende. Hämtad 19-03-19 från https://www.socialstyrelsen.se/statistik-och-data/oppnajamforelser/socialtjanst/aldreomsorg/hemtjanst-och-sarskilt-boende/

Socialstyrelsen. (2019). Vård och omsorg om äldre. Lägesrapport 2019.

SOSFS 2012:3. Värdegrunden i socialtjänstens omsorg om äldre. Stockholm: Socialstyrelsen.

SOU 2017:21. Läs mig! Nationell kvalitetsplan för vård och omsorg om äldre personer. Betänkande av Utredningen om nationell kvalitetsplan för äldreomsorgen. Stockholm: Wolters Kluwer.

Stake, R. E. (1995). The art of case study research. Thousand Oaks: SAGE Publications, Inc.

Stephens, J., Simpson, T., Holmes, O. S., Collins, R., Silver, M. \& Bhar, S. S. (2016). Volunteers Befriending Older Adults in Aged Care Residencies: Three Case Studies: Befriending in aged care residencies. Australian Psychologist, 51(2), 164-170.

Strang, S., Henoch, I., Danielson, E., Browall, M. \& Melin-Johansson, C. (2014). Communication about existential issues with patients close to death - nurses' reflections on content, process and meaning. Psycho-Oncology, 23, 562-568.

Stranz, A. (2018). Att arbeta på äldreboende: En jämförelse över tid och mellan stad, tätort och landsbygd. I H. Jönsson \& M. Szebehely (red.), Äldreomsorger i Sverige. Lokala variationer och generella trender. (s. 185-200). Malmö: Gleerups. 
Sundin, K., Jansson, L. \& Norberg, A. (2000). Communicating with people with stroke and aphasia: understanding through sensation without words. Journal of Clinical Nursing, 9, 481-488.

Sundler, A. J., Eide, H., van Dulmen, S. \& Holmström, I. K. (2016). Communicative challenges in the home care of older persons - a qualitative exploration. Journal of Advanced Nursing, 72, $2435-2444$.

Sveriges Kommuner och Regioner (SKR). (2019). Valfrihetssystem i kommuner 2019 Beslutsläget i införandet av LOV. Hämtad 20-02-16 från https://skr.se

Synonymer (2020). Hämtad 20-03-14 från https://www.synonymer.se/

Szebehely, M. (Red.) (2005). Äldreomsorgsforskning i Norden. En kunskapsöversikt.

Velferdsforskningsprogrammet. TemaNord 2005:508. Köpenhamn: Nordiska Ministerrådet.

Szebehely, M., Stranz, A. \& Strandell, R. (2017). Vem ska arbeta i framtidens äldreomsorg? (Arbetsrapport 2017:1). Stockholm: Stockholms universitet.

Taube, E. (2015). Loneliness: an essential aspect of the wellbeing of older people. (Doktorsavhandling, Lunds universitet, Institutionen för hälsovetenskaper).

Tillich, P. (1963). The eternal now. London: SCM Classics.

Todres, L., Galvin, K. \& Dahlberg, K. (2014). "Caring for insiderness": phenomenologically informed insights that can guide practice. International Journal of Qualitative Studies on Health and Well-being, 9, 21421.

Tornstam, L. (2005). Åldrandets socialpsykologi. Stockholm: Norstedts akademiska förlag.

Tornstam, L. (2007). Stereotypes of Old People Persist. A Swedish "Facts on Aging Quiz" in a 23 year Comparative Perspective. International Journal of Ageing and Later Life, 2(1), 33-59.

Tranströmer, T. (1970). Mörkerseende. Göteborg: Författarförlaget.

Törnquist, A. (2004). Vad man ska kunna och hur man ska vara: En studie om enhetschefers och vårdbiträdens yrkeskompetens inom äldreomsorgens särskilda boendeformer. (Doktorsavhandling, Lärarhögskolan i Stockholm, Institutionen för Samhälle, kultur och lärande).

Udo, C. (2012). Existential issues in surgical care: Nurses' experiences and attitudes in caring for patients with cancer. (Doktorsavhandling, Mittuniversitetet, Institutionen för hälsovetenskaper).

Udo, C., Danielson, E. \& Melin-Johansson, C. (2013). Existential issues among nurses in surgical care - a hermeneutical study of critical incidents. Journal of Advanced Nursing, 69(3), 569-577.

United Nations Volunteers. (2018). Overview: Volunteerism: The thread that binds. Hämtad från http://unv-swvr2018.org/

Volontärbyrån. (u.å.) Volontärbyrån. Hämtad 20-01-21 från https://www.volontarbyran.org/

van der Vaart, W. \& van Oudenaarden, R. (2018). The practice of dealing with existential questions in long-term elderly care. International Journal of Qualitative Studies on Health and Well-being, 13(1), 1508197-1508197. 
Wadensten, B. (2005). The content of morning time conversations between nursing home staff and residents. International Journal of Older People Nursing in association with Journal of Clinical Nursing, 14(8B), 84-89.

Wenemark, M. (2017). Enkätmetodik med respondenten i fokus. Lund: Studentlitteratur.

Westin, L. \& Danielson, E. (2007). Encounters in Swedish nursing homes: a hermeneutic study of residents' experiences. Journal of Advanced Nursing, 60(2), 172-180.

Whitaker, A. (2010). The body as existential midpoint: the aging and dying body of nursing home residents. Journal of Aging Studies, 24(2), 96-104.

WHO (u.å.). World Health Organization. WHO Definition of Palliative Care. Hämtad 20-03-15 från http://www.who.int/cancer/palliative/definition/en/

WHO (2015). World Health Organization. World Report on Ageing and Health.

WMA (2013). World Medical Association. Declaration of Helsinki: ethical principles for medical research involving human subjects. Hämtad 20-01-01 från https://www.wma.net/policiespost/wma-declaration-of-helsinki-ethical-principles-for-medical-research-involving-humansubjects/

Wolf, A., Ekman, I. \& Dellenborg, L. (2012). Everyday practices at the medical ward: a 16-month ethnographic field study. BMC Health Services Research, 12(184), 1-12.

Yalom, I. (1980). Existential psychotherapy. New York: Basic Books.

Årestedt, L., Benzein, E., Persson, C. \& Rämgård, M. (2016). A shared respite - The meaning of place for family well-being in families living with chronic illness. International Journal of Qualitative Studies on Health and Well-being, 11(1), 30308.

Österlind, J. (2009). När livsrummet krymper. Vård och omsorg om äldre i livets slutskede. (Doktorsavhandling, Örebro universitet, Institutionen för vårdvetenskap). 
APPENDIX 



\section{APPENDIX Enkätfrågor}

\section{FRÅGOR OM DIN ENHET DÄR DU ÄR CHEF/LEDARE}

1.1 Vårdformen på den enhet där Du är verksam som chef/ledare är? ${ }^{1}$

$\square$ Hemtjänst

$\square$ Servicehus

Gruppboende

$\checkmark$ Särskilt boende

Trygghetsboende

annan:

1.2 Har enheten någon specialinriktning ${ }^{1}$

c Demensvård

प Korttidsvård

प Växelvårdsplatser

C Palliativ vård

Annan:

1.3 Enheten där Du är verksam som chef/ledare är inom

$\square$ Offentlig regi

$\square$ Privat regi

Q Stiftelseform, kooperativ, intraprenad eller liknande

1.4 Antal personer som Du har personalansvar för?

ㄴ 1-10

ㅁ 11-30

प 31-50

$\square$ 51-70

$\square$ Fler än 70

$\square$ Har inget personalansvar

1.5 Vilka personalkategorier har Du ansvar för? ${ }^{1}$

$\square$ Vårdbiträden

口 Undersköterskor

$\square$ Sjuksköterskor

$\square$ Arbetsterapeuter

$\square$ Fysioterapeuter

$\square$ Kost- och städpersonal

1.6 Finns det personal på din enhet som har begränsad förmåga att samtala på svenska?

$\square$ Ja

$\square$ Nej

$\square$ Vet inte

Om ja, ungefär ur stor andel? (Ange i procent).

1.7 Finns det boende/vårdtagare på din enhet som talar ett språk som inte behärskas av någon i personalen?

$\square \mathrm{Ja}$

$\square \mathrm{Nej}$

$\square$ Vet inte

\footnotetext{
${ }^{1}$ möjlighet att ange mer än ett svarsalternativ
} 


\title{
2. FRÅGOR OM EXISTENTIELL ENSAMHET OCH EXISTENTIELLA FRÅGOR
}

Existentiell ensamhet (en djupare känsla av ensamhet) associerar du till:
Instämmer inte alls
Instämmer helt Har ingen uppfattning

2.1 Livet, mening ${ }^{2}$

2.2 Döende, döden, förluster

$\square \quad \square$

$\square \quad \square$

口 $\square$

$\square \quad \square$

2.3 Frihet, autonomi, självbestämmande

2.4 Ensamhet, att sakna relationer

$\square \quad \square$

$\square$

$\square$

$\square$

$\begin{array}{llll}\square & \square & \square & \square\end{array}$

2.5 Annat:

2.6 Finns det boende/vårdtagare på din enhet som ger uttryck för existentiell ensamhet?

$\square$ Ofta

口 Ibland

$\square$ Sällan

$\square$ Aldrig

$\square$ Vet ej

2.7 Händer det att personalen pratar med de boende/vårdtagarna om existentiella frågor?

$\square$ Ofta

$\square$ Ibland

$\square$ Sällan

Aldrig

$\square$ Vet ej

2.8 Om personalen pratar om existentiella frågor med de boende/vårdtagarna, kan Du ge exempel på vad samtalen kan handla om?

\author{
2.9 Händer att arbetsgruppen pratar om existentiella frågor? \\ $\square$ Ofta \\ $\square$ Ibland \\ $\square$ Sällan \\ $\square$ Aldrig \\ $\square$ Vet ej
}

2.10 Om arbetsgruppen pratar om existentiella frågor, kan Du ge exempel på vad samtalen kan handla om?

2.11 Om det finns hinder hos den äldre att prata om existentiella frågor - vad kan det bero på? ${ }^{1}$

$\square$ Nedsatt kognition (pga demenssjukdom eller stroke t ex)

$\square$ Afasi

$\square$ Osäkerhet att prata om existentiella frågor

$\square$ Ovilja/olust att prata om existentiella frågor

口Språk (att man inte talar samma språk)

口Annat:

2.12 Om det finns hinder hos personalen att prata om existentiella frågor - vad kan det bero på? ${ }^{1}$

口 Osäkerhet att prata om existentiella frågor

$\square$ Ovilja/olust att prata om existentiella frågor

G Språk (att man inte talar samma språk)

$\square$ Annat:

${ }^{2}$ detta svarsalternativ var felvänt i den utskickade enkäten 


\section{FRÅGOR OM PERSONALEN}

3.1 Har personalen möjlighet att ha enskilda samtal med de äldre i vardagen?

口 Ofta

I Ibland

प Sällan

Aldrig

3.2 Ges personalen stöd i att möta och samtala om existentiella frågor med boende/vårdtagare?

$\square \mathrm{Ja}$

$\square$ Nej

3.3 Om ja, hur sker det? ${ }^{1}$

$\square$ Regelbunden handledning

$\square$ Reflektion under strukturerade former

$\square$ Samtal med dig som enhetschef (individuellt)

$\square$ Samtal med sjuksköterska (individuellt)

Utbildning

Annat:

3.4 Vilket ytterligare behov av stöd tror Du att personalen skulle behöva? I så fall vilket?

3.5 Finns det hinder i organisationen för att kunna ge detta stöd? I så fall vilka?

\section{FRÅGOR OM VOLONTÄRER}

En volontär är en person som erbjuder sina tjänster frivilligt utan att kräva betalning, ofta organiserat genom frivilligorganisation. I Sverige idag kallas volontärer ibland för frivilliga, ideella eller aktiva medlemmar.

4.1 Finns det volontärer på Din enhet?

$\square \mathrm{Ja}$

प Nej (Om nej, gå vidare till fråga 4. 11 som endast besvaras av de som inte har volontärer)

4.2 Om ja, vilken organisation tillhör de ${ }^{1}$

口 Svenska Kyrkan

$\square$ Röda Korset

$\square$ Volontärverksamhet anordnad av kommunen

$\square$ Självorganiserad verksamhet, typ Väntjänst

$\square$ Annan organisation:

4.3 I vilken omfattning finns det volontärer på Din enhet?

$\square$ Varje dag

$\square$ Ett par dagar i veckan

$\square$ Ett par gånger i månaden

$\square$ Mer sällan än 1 gång i månaden

4.4 Vilka aktiviteter deltar volontärerna i på Din enhet? ${ }^{1}$

$\square$ Promenader/utevistelser

Läsning

Musik/underhållning

口Vardagliga samtal 
USamtal om existentiella frågor

$\square$ Annat:

4.5 Händer det att volontärerna pratar med de boende/vårdtagarna om existentiella frågor?

पofta

$\square$ Ibland

पällan

$\square$ Aldrig

$\square$ Vet ej

4.6 Vilka aktiviteter skulle Du önska att volontärer deltog i? ${ }^{1}$

口 Promenader/utevistelser

$\square$ Läsning

Musik/underhållning

$\square$ Vardagliga samtal

$\square$ Samtal om existentiella frågor

口Annat:

4.7 Finns det hinder för att involvera volontärer i sådana aktiviteter?

$\square \mathrm{Ja}$

$\square \mathrm{Nej}$

Om ja, i så fall vad?

4.8 Är du som chef/ledare involverad i att introducera volontärerna i verksamheten på din enhet?

$\mathrm{CJa}$

$\square \mathrm{Nej}$

Om ja, hur då?

4.9 Har Du gemensamma träffar med volontärerna där ni diskuterar de aktiviteter de deltar i?

$\square \mathrm{Ja}$

$\square \mathrm{Nej}$

4.10 Händer det att Du samtalar om existentiella frågor vid dessa träffar?

$\square \mathrm{Ja}$

$\square \mathrm{Nej}$

FÖLANDE FRÅGOR BESVARAS ENDAST OM NI I NULÄGET INTE HAR VOLONTÄRER PÅ ER ENHET.

4.11 Finns det något som volontärer skulle kunna bidra med på din enhet?

$\square \mathrm{Ja}$

$\square$ Nej

$4.12 \mathrm{Om}$ ja, i så fall vad? ${ }^{1}$

口Promenader/utevistelser

$\square$ Läsning

口Musik/underhållning

प Vardagliga samtal

प Samtal om existentiella frågor

口Annat, i så fall vad?.

4.13 Om det finns hinder för att involvera volontärer på din enhet, i så fall vilka? 


\section{FRÅGOR OM DIG SOM CHEF/LEDARE}

5.1 Vilken befattning har du?

$\square$ Enhetschef

$\square$ Områdeschef

$\square$ Verksamhetschef

口Annat..

5.2 Är du

C Kvinna

$\square$ Man

$\square$ Annan

5.3 Vilken är din ålder?.

5.4 Har du professionsutbildning med en högskoleexamen?

$\square \mathrm{Ja}$

$\square$ Nej

Om ja, i så fall vilken?

$\square$ Socionom/Social omsorg

प Sjuksköterska

$\square$ Arbetsterapeut

DFsioterapeut

口Annan, i så fall vilken?

5.5 Har Du chefs/ledarskapsutbildning?

$\square \mathrm{Ja}$

$\square \mathrm{Nej}$

5.6 Hur länge har Du arbetat som chef/ledare inom vård-och omsorg?

Mindre än 1 år

प1-5 år

प6-10 år

पMer än 10 år

5.7 Hur länge har Du arbetat som chef/ledare på den aktuella enheten?

पMindre än 1 år

प1-5 år

प6-10 år

口Mer än 10 år

6. ÖVRIGT

6.1 Övriga kommentarer eller reflektioner 



\section{DELSTUDIE I-IV}





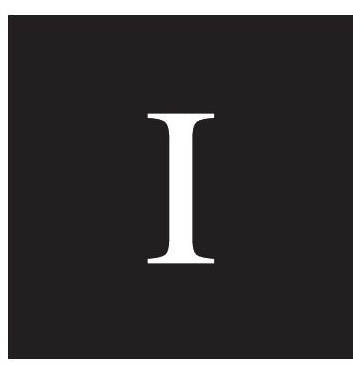





\title{
Encountering existential loneliness among older people: perspectives of health care professionals
}

\author{
Malin Sundström (10 ${ }^{\mathrm{ab}}$, Anna-Karin Edberg (10), Margareta Rämgård (ib ${ }^{\mathrm{b}}$ and Kerstin Blomqvist (1) ${ }^{\mathrm{a}}$ \\ ${ }^{a}$ Research Platform for Collaboration for Health, Faculty of Health Science, Kristianstad University, Kristianstad, SWEDEN; ${ }^{\text {bFaculty of }}$ \\ Health and Society, Malmö University, Malmö, SWEDEN
}

\begin{abstract}
Purpose: Existential loneliness is part of being human that is little understood in health care, but, to provide good care to their older patients, professionals need to be able to meet their existential concerns. The aim of this study was to explore health care professionals' experiences of their encounters with older people they perceive to experience existential loneliness. Method: We conducted 11 focus groups with 61 health professionals working in home care, nursing home care, palliative care, primary care, hospital care, or pre-hospital care. Our deductive-inductive analytical approach used a theoretical framework based on the work of Emmy van Deurzen in the deductive phase and an interpretative approach in the inductive phase. Results: The results show that professionals perceived existential loneliness to appear in various forms associated with barriers in their encounters, such as the older people's bodily limitations, demands and needs perceived as insatiable, personal shield of privacy, or fear and difficulty in encountering existential issues. Conclusion: Encountering existential loneliness affected the professionals and their feelings in various ways, but they generally found the experience both challenging and meaningful.
\end{abstract}

\section{ARTICLE HISTORY}

Accepted 4 May 2018

KEYWORDS

Existential loneliness; older people; health care professionals; qualitative study; focus group; encounter; life world

\section{Introduction}

To avoid unnecessary suffering in older people, health care professionals in all professions and care contexts need to meet these people's existential concerns. Although previous research shows that nursing staff are willing to pay attention to existential issues (Strang, Strang, \& Ternestedt, 2002), more recent research shows that it is difficult and challenging to find time and space for this in everyday elderly care (Beck, 2013; Norell Pejner, 2013; Sundler, Eide, Van Dulmen, \& Holmström, 2016). This can lead nursing staff to feel compelled to focus more on practical tasks than on relations with the older people and their relatives (Beck, 2013). In turn, when care is focused more on tasks than on the relational aspects that allow a good encounter, older people often feel alienated and lonely (Svanström, Sundler, Berglund, \& Westin, 2013). The concept of loneliness is ambiguous and includes both the objective dimension of being alone and the subjective dimension of feeling lonely despite having people around (Dahlberg, 2007). This study has its starting point in existential aspects of loneliness, existential loneliness in a caring context, and how professionals experienced existential loneliness in the encounter with older people.

Loneliness has been described extensively in relation to death, guilt, and other existential aspects of being human, often by and with reference to philosophers such as Frankl, Heidegger, and Yalom. Although loneliness has been described as a part of being human (Yalom, 1980) and a part of the human predicament (Tillich, 1963) in terms such as aloneness, solitude, and isolation, no clear consensus has been reached on a definition of the concept in general (Karnick, 2005) or of existential loneliness in particular (Ettema, Derksen, \& van Leeuwen, 2010). Loneliness also has different aspects and meanings. Dahlberg (2007) described loneliness as restful and creative, and Tillich (1963) distinguished loneliness, the pain of being alone, from solitude, the glory of being alone, and emphasized the greater significance of loneliness to the health and care of a person suffering and in need of care. It is therefore reasonable to believe that health care professionals have seen both loneliness and existential loneliness in the older people in their care.

Existential loneliness is related to feeling disconnected from the world, lost without a purpose, and adrift in life. Existential loneliness can also arise when people lack previous experience of their situation or in times of uncertainty such as during an illness. Jaspers (1994) defined 'limit situations' (i.e., death, suffering, struggling, faith, and guilt) as closely connected to life, and therefore inevitable and unescapable, whereas Tillich (1963) defined guilt and death as two forms of loneliness that cannot be covered up or

CONTACT Malin Sundström malin.sundstrom@mau.se Faculty of Health and Society, Malmö University, SE 205 06 Malmö, SWEDEN

() 2018 The Author(s). Published by Informa UK Limited, trading as Taylor \& Francis Group.

This is an Open Access article distributed under the terms of the Creative Commons Attribution License (http://creativecommons.org/licenses/by/4.0/), which permits unrestricted use, distribution, and reproduction in any medium, provided the original work is properly cited. 
escaped. According to Applebaum (1978), the full impact of existential loneliness is often felt during the contemplative realization of one's aloneness in the universe, and responses can vary from fright to excitement and acceptance of reality and one's autonomy. Ettema et al. (2010) described three dimensions of existential loneliness as (1) a condition, (2) an experience, and (3) a process of inner growth, indicating its positive as well as negative aspects, which concern aspects of being with others in fellowship and connectedness, and of being without others.

For most people, ageing brings losses of important aspects of life such as family members, friends, abilities, and physical functions. The impact of these losses and how they are managed seem to be associated with feelings of loneliness (Kirkevold, Moyle, Wilkinson, Meyer, \& Hauge, 2013). Unlike separation anxiety, loneliness arises when a loss has occurred, rather than when it is feared. Although the two feelings can occur simultaneously, they should not be confused with each other (Applebaum, 1978). Harris (2015) described existential losses during the course of a life-limiting illness (motor neuron disease) as losses of past ways of being in the world, embodiment, spatiality, and the future. In a systematic review by Hallberg (2004) into older people's views on death and dying, older people showed a need to talk about existential issues, of time past and time to come, as well as of dying and death. If existential thoughts and reflections at this point are not recognized or affirmed, anxiety or existential loneliness (feeling alone in the world despite having people around) can arise (Sand \& Strang, 2006). This suggests a need for further exploration to deepen our understanding of existential loneliness in the caring context.

Caring is an interpersonal interaction that is part of being human (Finfgeld-Connet, 2008; McCormack \& McCance, 2010), and the professional's main responsibility in encounters with patients and their families is to be caring. However, such caring may be constrained by nurses' own insecurities and perceptions of older people's attitudes towards death; nurses might avoid discussing existential issues and death in an effort to avoid reinforcing a patient's feeling of hopelessness (Udo, Danielson, \& MelinJohansson, 2012). A study by Norell Pejner, Ziegert, and Kihlgren (2012) showed that although nurses considered giving emotional support to older people important, and knowing when it is needed as part of their professional skill set, work conditions did not always allow time for that. Ericson-Lidman, Norberg, Persson, and Strandberg (2013) showed that health care personnel were troubled by conscience when caught between various demands, rules, and recommendations that did not benefit the older people; they felt unable to relieve suffering and provide proper care to their patients. This indicates that being unable to work and act according to one's values could create a feeling of guilt among professionals and promote neither good encounters nor good relations.

Another challenge for nurses was shifting their perspective from that of a busy professional in a care unit full of activity to the slower pace and "insiderness" of the older people's perspectives. Although we can never fully understand someone else's life world, "reaching towards" otherness as a process and practice is often more important than "knowing" the details of someone's "insiderness" and is something to strive for (Todres, Galvin, \& Dahlberg, 2014). Existential issues and caring are closely connected, and caring can be seen as an ethical aspect and a wisdom-based side of nursing (Udo, 2014). Thus, knowledge about nurses' and other health care professionals' encounters with older people perceived to be experiencing existential loneliness is vitally important to the development of supportive interventions for health care professionals.

\section{Aim}

The aim of this study was to explore health care professionals' experiences of their encounters with older people they perceive to experience existential loneliness.

\section{Method}

This study forms part of the larger LONE study (Edberg \& Bolmsjö, 2017) exploring existential loneliness among frail older people from the differing perspectives of the older people, their relatives, and their health care professionals. Frail older people were defined as those aged $\geq 75$ years receiving long-term care from formal caregivers provided by the municipality or the county council. The LONE study is in the development phase of designing a complex intervention (MRC, 2008).

\section{Design}

This qualitative study was based on focus group interviews with professionals in different health care contexts. Focus groups were chosen to obtain a range of experiences (Krueger \& Casey, 2009). We used a deductive-inductive approach in the analysis. According to Polit and Beck (2012), an emerging design based on reflective decisions can be used during the process of a qualitative study. In a first deductive phase, we used a concept-driven strategy (Schreier, 2012) based on a theoretical framework by van Deurzen (2012) followed by an inductive phase combined with an interpretative approach (Figure 1). 
Figure 1. The four steps of the analysis.

\section{Participants and context}

In total, 11 focus group (FG) interviews were conducted in health care settings in urban and rural areas in the south of Sweden. For variation, we included home care, nursing home care, palliative care, primary care, hospital care, and pre-hospital care settings. Participants $(n=61)$ were also selected purposively to gain a range of caring perspectives from nurse assistants (licensed practical nurses and nurse aides), registered nurses, physicians, occupational therapists, physiotherapists, social counsellors, and social workers (Table I). Although the participants had different functions and tasks in relation to the older people, in this study are all referred to as professionals or health care professionals.

\section{Data collection}

All FGs $(n=11)$ were conducted at the participants' workplace in mixed groups of 3 to 8 professionals ( $m d=6$ ). Prior to the interviews, participants were given written and oral information about the purpose of the study and assurance that their participation was voluntary and they could withdraw without any explanation. The information letter also included a brief text about existential loneliness in the context of caring and the LONE study as a whole. To safeguard the principle of autonomy, participants were given time between the first information and the FG to consider participating (Beauchamp \& Childress, 2013). The information was repeated before written consent was collected and again before the interview.

The interviews were led by two researchers, one (M.S.) acting as facilitator and one (K.B. or M.R.) as observer. The interview guide was first tested in a pilot interview that led to a few adjustments. The interview guide began with an introduction. To focus the discussion, participants were then asked about their views on old people's loneliness in general and existential loneliness in particular (Krueger \& Casey, 2009). We requested stories about encountering existential loneliness by asking:
We are particularly interested in a deeper feeling of being alone in life, sometimes called existential loneliness, a feeling that can come and go. Can you remember an experience with an older person who

Table I. Characteristics of focus group participants.

\begin{tabular}{|c|c|c|}
\hline Characteristics & $\mathrm{n}=61$ & Specialist training \\
\hline \multicolumn{3}{|l|}{ Age } \\
\hline Range (md) & $26-68(49)$ & \\
\hline \multicolumn{3}{|l|}{ Gender } \\
\hline Women (\%) & $55(90)$ & \\
\hline Men (\%) & $6(10)$ & \\
\hline \multicolumn{3}{|l|}{ Profession } \\
\hline Nurse assistant & 22 & \\
\hline Registered nurse & 25 & \\
\hline Physician & 5 & \\
\hline $\begin{array}{l}\text { Occupational } \\
\text { therapist }\end{array}$ & 2 & \\
\hline Physiotherapist & 3 & \\
\hline Social counsellor & 3 & \\
\hline $\begin{array}{l}\text { Social worker/Case } \\
\text { officer }\end{array}$ & 1 & \\
\hline $\begin{array}{l}\text { Additional specialist } \\
\text { training/ } \\
\text { specialized } \\
\text { orientation (> one } \\
\text { year) }\end{array}$ & 27 & \\
\hline Nurse assistant & 3 & $\begin{array}{l}\text { Palliative care, Home care } \\
\text { rehabilitation }\end{array}$ \\
\hline Registered nurse & 17 & $\begin{array}{l}\text { Oncology and palliative care, Primary } \\
\text { health care, Pre-hospital care, } \\
\text { Intensive care, Anaesthesia care, } \\
\text { Elderly care }\end{array}$ \\
\hline Physician & 5 & $\begin{array}{l}\text { Oncology and palliative medicine, } \\
\text { General Practitioner, Geriatrics }\end{array}$ \\
\hline $\begin{array}{l}\text { Occupational } \\
\text { therapist }\end{array}$ & - & \\
\hline \multirow{2}{*}{$\begin{array}{l}\text { Physiotherapist } \\
\text { Social counsellor }\end{array}$} & - & \\
\hline & 2 & $\begin{array}{l}\text { Cognitive behavioural therapy, } \\
\text { Psychodynamic therapy }\end{array}$ \\
\hline Social worker & - & \\
\hline $\begin{array}{l}\text { Professional work } \\
\text { experience in } \\
\text { health care, } y r\end{array}$ & & \\
\hline Range (md) 4 & 4-43 (19) & \\
\hline \multicolumn{3}{|c|}{$\begin{array}{l}\text { Work experience in } \\
\text { the present } \\
\text { organization, } y r\end{array}$} \\
\hline Range (md) $\quad 0$. & $0.5-42(9)$ & \\
\hline \multicolumn{3}{|c|}{ Participants from } \\
\hline Home care & 16 & \\
\hline Nursing home & 11 & \\
\hline Palliative care & 16 & \\
\hline Primary care & 4 & \\
\hline Hospital care & 9 & \\
\hline Pre-hospital care & 5 & \\
\hline
\end{tabular}


had this deeper kind of loneliness, of being alone in the world? Could you please provide a concrete narrative?

Follow-up questions were asked when clarification was needed. The facilitator tried to create a supportive atmosphere to encourage interaction and reflection on the topic and emphazied that there were no right or wrong answers. The observer made notes and summarized the discussions at the end of the interviews, which lasted for approximately two hours and were audio-recorded and transcribed verbatim by a trained transcriber. One recording was interrupted by technical problems and the missing part reconstructed from the notes, augmented by an audiorecorded conversation between the observer and the facilitator shortly afterwards. The FGs were conducted from January 2015 to September 2016. Parts of the interview data that concerned existential loneliness in relation to the care context and strategies to handle existential loneliness will be presented elsewhere.

\section{Ethical aspects}

One or two researchers from the LONE study informed participants about the project as a whole and handed out written information at meetings in the participating health care settings. For practical reasons, a designated contact person in each care setting then collected the names of those who wanted to participate and gave them to the researchers. The contact person was either a staff member or a manager, so there is a risk that some participants felt pressured to participate. However, the researchers highlighted the voluntariness of participation before each FG. The composition of the groups of staff from different professions in the same workplace could have influenced the interactions by making participants feel either comfortable or uncomfortable in the discussions. The researchers were aware of this possibility and tried to facilitate everyone's opportunity to have their say without feeling constrained. This study was approved by the Ethical Review Board, Lund, ref. 2014/652, as a part of the LONE study.

\section{Pre-understandings}

All authors are registered nurses with experience in geriatric nursing, education, and research. Our preunderstandings were articulated during the planning of this study. We defined existential loneliness as a feeling that could come and go among people in general. We assumed that existential loneliness is common among older people in need of care and that it is related to thoughts of death. We also believed that encountering older people's existential loneliness was a challenge for which professionals could need support to meet.

\section{Analysis}

The analysis was conducted in a process of moving back and forth between four steps (Figure 1). In the first step, all authors read the text to gain an overview and a sense of the whole. We looked for different aspects of health care professionals' encounters with existential loneliness among older people and identified stories and descriptions related to the aim. In the second step, we structured these stories and descriptions on an analytical grid inspired by the life world theory of philosopher and existential psychotherapist, Emmy van Deurzen. Van Deurzen's framework includes four dimensions: the physical world, the social world, the personal world, and the spiritual world (van Deurzen, 2012) (Table II).

This step was concept-driven (Schreier, 2012) which is a deductive course of action using an already existent theory, concept, or, as in this study, a framework, where the life world theory acted as a coding frame. In the third step, analytical questions were addressed to the text:What competencies and abilities are professionals using in encountering and interpreting older people's existential loneliness? What are the professionals' perceptions and interpretation of older persons' existential loneliness? How do professionals describe that existential loneliness is expressed? What are professionals own experiences of encountering older persons' existential loneliness? In the fourth step, we looked for significant patterns in the answers to the analytical questions and categories to describe the challenges professionals faced in the encounters with older people's existential loneliness. The overarching category was barriers in the encounter.

Table II. Description of the four dimensions of van Deurzen's theory of the life world (van Deurzen, 2012).

\begin{tabular}{|c|c|}
\hline $\begin{array}{c}\text { The Physical } \\
\text { World }\end{array}$ & $\begin{array}{l}\text { The most fundamental world, based on the } \\
\text { assumption that human existence is rooted in the } \\
\text { body, and includes the relation to nature, body, } \\
\text { and oneself on a physical level. }\end{array}$ \\
\hline $\begin{array}{c}\text { The Social } \\
\text { World }\end{array}$ & $\begin{array}{l}\text { The world about the human existence in relation to } \\
\text { others in the world with all aspects of social } \\
\text { interaction as in ordinary meetings with others, } \\
\text { human relations in the public world, and an } \\
\text { inevitable part of life. }\end{array}$ \\
\hline $\begin{array}{c}\text { The Personal } \\
\text { World }\end{array}$ & $\begin{array}{l}\text { The world of closeness, to oneself and in other close } \\
\text { relations. } \\
\text { A psychological dimension including private } \\
\text { experiences and identity. }\end{array}$ \\
\hline $\begin{array}{c}\text { The Spiritual } \\
\text { World }\end{array}$ & $\begin{array}{l}\text { The world about what creates meaning, about the } \\
\text { person's connection with the abstract elements in } \\
\text { life and ideal values. About spiritual thoughts, } \\
\text { beliefs and aspirations about life and the world } \\
\text { beyond the person. }\end{array}$ \\
\hline
\end{tabular}




\section{Findings}

The professionals experienced existential loneliness among older people in various ways and situations. The condition was not static, but instead came and went. The professionals' perceptions and interpretations of older patients' existential loneliness and their own experiences of encountering existential loneliness are presented as barriers in the encounters: (1) Insecurity when trying to interpret and understand needs and desires; (2) Reluctance to meet demands and needs perceived as insatiable; (3) Insecurity about how to break through the personal shield; and (4) Fear and difficulty in encountering existential issues (Figure 2).

Regardless of what the barriers were about, staff described individual characteristics and abilities that made it easier for them to overcome these barriers. However, some characteristics and abilites were more prominent in some encounters. Characteristics such as empathy, compassion, courage, curiousity, and openmindedness were helpful in overcoming barriers, and the abilities to listen, to empathize, to reflect, and to switch perspective to the older person's life world seemed significant in the encounters. Familiarity with the person's past and present history, culture, and society were also important for professionals to comprehend the older people's situations. Finally, professionals' own norms and preferences combined with lack of knowledge of the ageing process could hinder professionals' abilities in encounters with existential loneliness.

\section{Insecurity when trying to interpret and understand needs and desires}

The professionals experienced insecurity when bodily limitations due to, among others, cognitive impairment, impaired hearing, and severe pain obstructed communication and interaction with others. They interpreted that the feeling of existential loneliness was characterized as being sad, abandoned, feeling anxiety, feeling fear, and being vulnerable and isolated.

Losing the ability to express themselves due to dementia or frailties limited older people's ability to express needs and desires. Cognitive impairment was a barrier that led to difficulties for older people in understanding what was happening and influencing their existence. A situation like that could be when an older person with dementia was separated from relatives when being a resident in a nursing home:

Yes, but I'm thinking about ... those times when they [her significant others] are not there, and she is still so sad, and she cries and cries, then she is sad because she is aware that, well "I'm here and they're there", and she misses them and longs for them. (Interview 7 -story 6)

To have needs, but be prevented by bodily frailty from expressing oneself or being understood by others led, according to the professionals, to isolation and existential loneliness. Even older people who prefer to withdraw to avoid misunderstandings, such as patients with a hearing impairment, were perceived to be isolated and separate from others. Professionals interpreted existential loneliness among older people with bodily limitations as an inability to escape, being condemned to see the world but not be a part of it, or as living in a world of their own.

Professionals described different expressions and signs of existential loneliness among older patients. Seeking contact by calling for attention in vulnerable situations was considered a sign of existential loneliness:

When they're lying there, crawling, or knocking with their cane on the wall, or knowing that the newspaper carrier is coming at five in the morning or something like that, that's when I can call for help. It feels like there's a deep feeling of loneliness in all that. (Interview 3-story 1)

Professionals' encounters with older patients' existential loneliness made them feel insecure, inadequate,

\begin{abstract}
INSECURITY WHEN TRYING TO INTERPRET AND UNDERSTAND NEEDS AND DESIRES

Professionals experience both the older people's inability to express their needs and desires and their own insecurity about interpreting and understanding those needs and desires as a barrier to communication.
\end{abstract}

INSECURITY ABOUT HOW TO BREAK THROUGH THE PERSONAL SHIELD

Professionals perceive an older person's creation of a personal shield as a protection against close human contacts and relations and experience the older people as distancing themselves.

\section{RELUCTANCE TO MEET DEMANDS AND NEEDS} PERCEIVED AS INSATIABLE

Professionals experience their reluctance to meet the older people's demands and needs for social contact as a barrier to their interactions and they distance themselves from the older people.

Figure 2. Professionals' experiences of barriers in the encounter.

\section{FEAR AND DIFFICULTY IN ENCOUNTERING} EXISTENTIAL ISSUES

Professionals perceive the older people to be alone in their lives because both older people and professionals have fear and difficulty talking about life, death, meaning, guilt and regret. 
and powerless due to the barrier of bodily limitations, but, in some cases, also compassionate. Feelings of inadequacy arose from not being able to reach the older people or interpret their needs and desires and instead having to rely on guesswork. Some professionals also experienced anger as a sign which was difficult to understand and get through. Encounters marked by mutual understanding were considered significant moments, especially when there were communication problems, such as in this case of dementia in a patient with Swedish as a foreign language:

"Oh yes, it is absolutely amazing those days when she's spending time with you and she's talking a few sentences in Swedish [and you can connect]" (Interview 7-story 6).

Older people's loss of independence evoked compassion and sadness in professionals, sometimes because of similar experiences with their own relatives. This helped professionals to open up to reflections about the conditions of life that could be used in their work with older people.

\section{Reluctance to meet demands and needs perceived as insatiable}

The professionals' experiences of older people's demands and needs for social contact with professionals or family members sometimes provoked in them a form of reluctance that acted as a barrier to interaction. Professionals considered older people's claims to, and longing for, contact as expressions of an existential loneliness characterized by sadness, homesickness or nostalgia, anxiety, anger, and fear of death or of dying alone. They also reflected that existential loneliness in older people was connected to feelings of invisibility and being forgotten.

Professionals' experience of older people's demands and needs for compassion made the professionals wish to distance themselves. Some of the patients had a strong need and desire for one person who could not be replaced. No amount or type of contact from professionals was ever enough:

"But even though you [home care staff] are there, there is still this empty space. Even though you are the one who is going there every day" (Interview 8story 7).

Hospital discharge was seen as a loss of safety for older patients for whom the hospital represented a sense of security. Vulnerability and loneliness at home were interpreted as threats to older people that could cause them severe pain or prompt them to call for an ambulance after discharge. Such frequent and recurrent help-seeking was also interpreted as a sign of difficulty in managing anxiety and loneliness in other ways. The professionals understood the patients' attempts to reach out for human contact and their longing for closeness and intimacy in the context of demands and needs perceived as insatiable as an expression of existential loneliness. The need for companionship was perceived to get stronger in times of loss and uncertainty.

The professionals described expressions and signs of existential loneliness differently. Older people using jargon or casual language could be a disguise for existential loneliness. Professionals considered that although older people's needs for companionship and attention from professionals remained constant, how older people behaved towards professionals and others differed. Another sign was when older people looked lonely even when they were with other people. Professionals also noticed more existential loneliness in older people who rarely had visits. These persons took an active approach to seeking contact, attention, and confirmation from professionals; some sought physical contact and others tried to prolong the conversation:

I recognize this, that is sort of being dragged into the space around these patients: "Don't go ...", and the [older] person tries to keep the conversation going and all that, to make you [health care professional] stay around for a bit longer. Or [the older person] talks very, very slowly so that the conversation goes on for a very, very long time. (Interview 6-story 2)

Professionals' encounters with their patient's existential loneliness were characterized by feelings of frustration and stress. They felt inadequate when they could not satify the older person's needs no matter how much they did:

\footnotetext{
"Yes, oh yes, it's all the time, talking and talking, and it's like ... you are there for socializing [an assessed activity] for an hour and you do things together, but still you still feel you haven't done enough" (Interview 6-story 3).
}

This could leave professionals feeling drained by relations that required both time and energy and were described as being dragged into a situation that was difficult to escape. The professionals felt they lacked suffient time and resources to support the older people properly, especially those who expressed or repeated their wish to die. Professionals hesitated about when it was time to discuss existential issues. During good encounters, their insight and understanding of the older person's situation grew and the relation became less enervating.

\section{Insecurity about how to break through the personal shield}

Professionals experienced insecurity when older people were perceived to distance themselves through a sort of psychic personal shield used as a protection against close human contacts and relations. This shield was understood to represent the person's 
reluctance to let anyone share their private sphere and it acted as a barrier to the relation between the professional and the older person. Professionals associated this shield with people who had always lived by their own rules and relied on themselves. They interpreted the existential loneliness of these people, characterized by anxiety, bitterness, and anger, as a result of their inability to maintain their own rules and independence. It was a painful feeling, deep inside the older person, that the professionals sensed as overwhelming.

Professionals experienced ambivalence in older people towards letting go of control and letting others, including family members, get close. These people had no one to talk intimately with and were perceived to keep their problems and existential thoughts to themselves. They were understood not to allow themselves to be weak, vulnerable, or dependent. These people also seemed unable to verbalize or communicate their situation and existential issues:

\footnotetext{
"so suddenly there comes a loneliness that you may not be able to communicate to others. And you may not even be able to put your finger on it yourself, either. It's just something that comes over you" (Interview 5-story 1).
}

The pleasant loneliness of solitude and the private sphere that was once a sanctuary no longer has the same value when family members, especially children and grandchildren, are occupied with their own lives. Although some older people said that their relatives were too busy to visit, they often talked about their relatives without really knowing (as the professionals often did) about their lives, their concerns, or their wishes to know more about the older person's situation. Another sign of existential loneliness, then, was when older people expressed loneliness while at the same time declining company:

She sometimes expresses feelings of loneliness, but when you go into her room and suggest something to do, she says "No, I don't want to cause any trouble to anyone ..." There is that kind of people, too. I don't know ... they feel that they don't want to put any burden on you ... and so on. So it can be like that, too, that some people think "No I don't want to talk ... or not talk ...", like "I don't want to be a problem to anyone." (Interview 8-story 6)

Professionals saw older people having difficulty in starting new relationships after the loss of relations and changes to their circumstances. When a professional found a "way in", and broke through the personal shield, the older person might express gratitude later after having resisted. Professionals identified a passive attitude in some older people who took very few initiatives and chose to stay behind the shield. However, others had a genuine need for peace and quiet before death and some wished to die alone in privacy.
Professionals' own encounters with existential loneliness were characterized by their commitment and will to get behind the older person's shield, but they felt insecure about how to do this. They expressed feeling responsibility for supporting the older people's well-being and felt that their actions were crucial. However, when they remained locked outside and not admitted behind the shield, they felt they had not done enough, especially when they sensed that they could ease the patients' feelings of existential loneliness through their support and understanding. They also tended to feel insecure when their own perceptions differed from what was customary according to the core values of their profession. One example was the rule not to allow anyone to die alone:

But she didn't want [to have people around when she was dying] and the children did not want [to go against the will of their mother]. There were a lot of discussions around here; it aroused many ... different kinds of feelings, because I think we put ourselves into her situation or into the children's situation. Like, "What is this? How would I feel if I were lying there?" Thats the way you think. But on the other hand, it's not me. (Interview 11 -story 3)

When older people expressed strong emotions, professionals often perceived them as a wall that hindered their ability to get close to the older person. This awoke their compassion and was remembered for years as an object of reflection and learning. When the patients chose to trust them and allowed them to break through the shield, professionals felt a sense of happy amazement.

\section{Fear and difficulty in encountering existential issues}

The professionals experienced fear and difficulty in encountering existential loneliness among the older people they perceived as existential lonely. At these moments, when encountering existential issues and aspects of life, they sensed anxiety, agony, aimlessness, and disappointment in the older people. These emotions were understood as feelings of rootlessness, abandonment, and hopelessness in the present situation. Most of these concerned the past, but older people also expressed concerns about the meaning of their present lives and futures.

Professionals also perceived that older people were often occupied by brooding reflections on their lives, imminent deaths, feelings of guilt, and regrets:

But this, I perceive as loneliness. His wife didn't understand him, we didn't understand him, and he didn't understand himself either. And it is about life and death then ... and he ... he was all into that now and he had regrets. (Interview 5-story 5)

Some older people were able to express their existential loneliness in words, but others did not know how. 
Conversations about existential issues and loneliness were sometimes intertwined with other topics. Expressions of regret and guilt over broken relationships or choices in life were interpreted as signs of existential loneliness, as were expressions of feeling useless, no longer significant to others, and alieniated from contemporary society. The professionals also noticed older patients' longing for people from their own generation who had experienced the same events and episodes they had. Others were focused on their body and signs of weakness and decline. Smoothing things over, apologizing, and hinting about feelings of shame were other signs of existential loneliness. Although professionals sensed these signs could be caused by existential ruminations, their own fear and difficulty in talking about existential matters were barriers in the encounter.

Professionals' encounters with older people's existential loneliness aroused existential concerns within themselves. The existential loneliness was considered to affect everyone involved and was difficult to endure, particularly when it was the professionals' own inability and fear that created the barrier. Reflections brought new insights about the encounters and the complexity of existential loneliness. Professionals were aware of their limited ability to eliminate the feeling of existential loneliness. Another insight was the importance of letting go of their own personal views of the situation. Talking about existential issues with older people required self-awareness and courage:

To me, being is existential. Not so much about religion, it is about living. Just to live your life, being here and now, to exist in full, to be whole. That is existence, I want us to dare to talk more openly about it (Interview 10-story 3)

Another reflection the professionals expressed was the importance of prioritizing conversation and talking about death and dying before it was too late. The opportunity to share existential thoughts with an older person brought them happiness and gratitude, and these encounters were remembered for years.

\section{Discussion}

The results pointed out the different barriers faced by professionals encountering existential loneliness in a caring context. These encounters with existential loneliness affected health care professionals' feelings of various kinds and to various degrees. The four identified barriers in the encounters, insecurity when trying to interpret and understand needs and desires, reluctance to meet demands and needs perceived as insatiable; insecurity about how to break through the personal shield; and fear and difficulty to encounter existential issues demand different approaches. This means facing different challenges of requiring different personal qualities such as empathy, courage, curiousity, and open-mindness in the encounter (Figure 3).

Obstructed communication and interaction due to cognitive impairment and bodily limitations was perceived and interpreted as giving rise to isolation and existential loneliness. However, the results showed that interpretations of the older people's experiences often had to be based on guesswork. We also found that professionals sometimes felt inadequate and insecure about how to connect to older people; for example, when an older person, because of impaired cognitive function, could not fully understand or grasp the situation. The challenge for professionals was therefore to overcome a barrier in terms of their own insecurity to interpret and understand these people's needs and desires. To connect to the older person requires empathy and the ability to enter into the other's life world. Professionals need to support older people, especially those with impairments, to maintain a caring encounter and avert possible existential loneliness, as highlighted in a study by Nyström (2006) of people with aphasia who suffered existential loneliness when unable to express themselves. These people also felt frustration and anger in their struggle to
TO OVERCOME THE INSECURITY AND GET THROUGH THE BODILY BARRIER

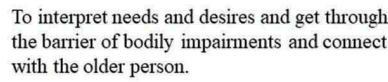

To interpret needs and desires and get through the barrier of bodily impairments and connect with the older person.

TO OVERCOME THE RELUCTANCE AND REMAIN IN THE ENCOUNTER

To have the strength to remain and endure in the encounter despite perceived insatiable needs and overcome the feeling of frustration and resistance.
TO OVERCOME THE INSECURITY AND FIND A 'WAY IN'

\footnotetext{
To get through the older person's shield against closer relations without infringing on their private sphere and integrity.
}

TO OVERCOME FEAR AND DIFFICULTY IN ENCOUNTERING EXISTENTIAL ISSUES

To discuss existential issues about life, death, meaning, guilt and regrets and to share what is found to be important for the older person.

Figure 3. Challenges in encountering older people's existential loneliness. 
communicate, and existential loneliness in the absence of professional support. In a case study on aphasia, communication loss was a hindrance to self-expression as a thinking and acting person that led to feelings of exclusion and changed the process of natural conversation in a world of others (Hjelmblink, Bernsten, Uvhagen, Kunkel, \& Holmström, 2007). Being unable to share thoughts left the person feeling alone in the world. To improve the quality of elder care, the impact of physical constraints on older people's feelings of alienation and loneliness must be brought into light along with the effect of professionals' feelings of inadequacy.

Older people's claims to and longing for social contact was perceived and interpreted as expressions of an existential loneliness that made the professionals distance themselves. Our findings showed that professionals often felt frustrated and inadequate. Having the support of their colleagues and opportunities to discuss and become aware of their own behaviours could help professionals find ways to deal with the situation. The challenge to overcome the reluctance to meet demands and needs perceived as insatiable requires the professional to have the strength to endure the encounter. The professional needs to meet the older person's feelings without becoming overwhelmed or exhausted. According to Charmaz (1983), people with chronic illnesses are still in great need of intimate social contacts, but can have difficulty maintaining relations because they are consumed by their illness and circumstances and therefore become more and more isolated. This could be one reason professionals distance themselves from patients. However, distancing may also be a way that professionals handle demanding situations and it should therefore not be overlooked as a potential sign for colleagues or managers to pay attention to. Group supervision is one alternative that, apart from offering an opportunity to share demanding situations with colleagues, could be an opportunity to simplify complexity and increase professionals' selfawareness and confidence (Taylor, 2014). Buber (1994) claimed that the person, in this case the professional, who knows the difference between "I and thou" and "I and it" can switch between the two to find meaning. However, if a professional is caught in one of those relations to the world, it can lead to consequences for both parties in caring and non-caring encounters. Reflecting with colleagues on the relationship between existential loneliness and health care could open up discussions of alternative approaches. Westin and Danielson (2007) showed that encounters with nursing home staff influenced older people's feelings of "being somebody" or "being nobody". Both residents and professionals effected the encounters, although professionals were responsible for the outcomes. An encounter that makes an older person feel like a "nobody" or an "it" is not caring and should be prevented, or acknowledged and remedied.

The older people's distancing due to a reluctance to share their private sphere was perceived and interpreted as giving rise to existential loneliness and painful feelings. Our results showed that professionals were committed and felt responsibility for supporting the older people but felt unsatisfied when being locked out. The challenge of overcoming the insecurity about how to break through the personal shield is twofold. It is necessary first to find a "way in" and second to do so without infringing on the older person's integrity. Because professionals were found to associate the personal shield with a person's character, it is important they have some knowledge of the person's personality and life story before the encounter. The older person may have a history and values of strength and independence that are important to respect. Tillich (1963) described a person with an impenetrable centre as free and this freedom is an aspect of being alone. This could be interpreted as integrity, but when being alone is no longer selfchosen and circumstances change, the glory of such solitude can fade. Professionals interpreted existential loneliness as a painful feeling, connected to the person's very existence, which implies that it can be appropriate to "knock on the door", but it is important not to be overconfident or insistent. Instead, a combination of courage and attention to the person's possible vulnerability is part of moral strength on the relational level (Lindh, Severinsson, \& Berg, 2009). This could open patients to encounters on their own terms. Nevertheless, it is important to respect the older person's integrity and not misinterpret self-choosen solitude as loneliness.

Older people being occupied by deep reflections on their lives in relation to guilt, regrets, and their current situation, but missing having anyone to share existential issues with, were interpreted as experiencing existential loneliness. Professionals experienced this kind of existential loneliness as difficult to endure, in particular when the professionals' own inability and fear hindered them. The results showed that professionals identified older people who were able to express their existential loneliness and distress in words, while others either did not know how or disguised their existential loneliness with other words or expressions. The challenge of overcoming fear and difficulty in encountering existential issues is to challenge one's own insecurity and try to find ways to share the older person's existential distress. Professionals therefore need to be attentive to signs of existential distress and open to discussions without feeling obliged to have the answers to everything. Frankl (2006) believed the meaning of life has to be found by each individual and is in constant, unceasing change, including during ageing and at the end of 
life, when reflection and brooding over existential issues are common. This is crucial and should not be underestimated or overlooked in ageing people, especially as there is a risk that assumptions and preconceptions about older people in contemporary society can lead to neglect of their needs. A study of health care professionals' perceptions found that among patients with advanced cancer, anticipation of a negative future, failure to find meaningful activities and relationships, and feelings of regret were causes of existential distress (Mok et al., 2010). Frankl (2006) emphasized the potential of life, even of the past, and emphasized that the accomplishments, joys, and sufferings of the past all give meaning to the present and the future. This strengthens the importance of cultivating an interest in the older patient as a person throughout time. When the barrier is the professionals' own fear, they first have to overcome that fear and develop courage and self-awareness to encounter whatever existential issues older people will share with them. One way of developing courage and self-awareness is through clinical supervision based on reflection in dialogue with others. Core concepts, besides self-awareness, in the nursing supervision model are confirmation and meaning (Severinsson, 2001). Self-awareness as well as awareness of the importance of encountering existential issues can most probably improve the care provided. Schuster (2006) pointed out the importance of becoming aware of the joint experience of being human, but also highlighted the importance of confirming the differences between the unique patient and the professional. The meaning of being professional is often discussed in the sense that one should not become personal in relation to the patient. Schuster (2006), however, denoted that in a professional existential space, the private sphere is left behind, and she claimed the possibility of being personal and still professional. To reach this, courage is required.

Depending on how professionals deal with the barrier, the encounter will become caring or uncaring. Caring encounters, as defined by patients, are provided by competent, concerned, respectful, open, and positive professionals who give patients an increased sense of well-being (Halldórsdóttir \& Hamrin, 1997). Our results are similar, showing that professionals' compassion, open-mindedness, and humility towards people's differences could serve as threefold basis for caring encounters and meeting existential loneliness. To create caring encounters and give older patients a sense of well-being, it is important for professionals to have opportunities to reflect on the care they give and on the existential issues their patients face. Ranheim (2009) stressed not only the importance of enough time in encounters with patients to recognize their existence as individuals, but also the need for professionals with enough sense to answer the "silent call" and the selfawareness and strength to recognize underlying concerns as well as explicit and easily solved issues. Existential issues concern all human beings-patients, older people, health care professionals, and everyone else. It is important to recognize and acknowledge the significance and meaning of existential issues in the caring relationship to provide good-quality care and support older persons' well-being.

\section{Methodological considerations and limitations}

Because there is no clear consensus on the concept of existential loneliness, we did not choose one definition. This may be seen as a weakness and a challenge to the credibility of our data (Guba, 1981). To counter this possibiliy, we introduced the concept to participants in the written information and introduced all the focus groups to the description of existential loneliness as a deeper kind of loneliness, a feeling of being alone in the world. The interview guide was first tested in a pilot interview with five people. They were all nurses, either students at advanced level or lecturers in a nursing programme. The pilot interview led to some adjustments of the guide and made us aware of the importance of requesting stories. Therefore, we asked for stories, which we expected would lead to depth in the interview data; however, we noticed a difference between participants in the degrees of their personal and emotional involvement and reflection in the stories. One interpretation could be that the professionals had experienced and reflected about existential loneliness to varying degrees; another could be that the climate in some focus groups hindered the participants from becoming very personal. Still, we believe that most focus groups had an open climate, although this did vary with different group dynamics. Further, the professionals did share many stories, sometimes from years ago, that could be interpreted as significant memories to them on both a professional and a personal level. The number of professionals in the groups varied between three and eight, which might have affected the opportunity to speak. Still, our opinion is that group dynamics and to let everyone have their say were more important for the climate than the number of participants. The study design involved participants from different professions and care contexts to help us achieve a result that could be transferable to encounters with older people in various care contexts. However, the participants in our study were probably more engaged in existential issues than professionals in general. If so, insecurity about encountering existential loneliness might be even more widespread.

The deductive-inductive design emerged over time, and according to Guba (1981) a naturalistic 
inquiry is not complete until it is terminated. During that time it is unfolding and not preordained. Using van Deurzen's framework (2012) was beneficial in explaining and understanding other aspects of existential loneliness, such as the frail body, and relations to oneself and to others. We described all four steps of the analysis and reported the analytical questions to increase dependability by establishing an audit trail (Guba, 1981). All four authors took part in various parts of the analysis over time including data collection, analysis, and drafting this paper, which strengthens the dependability and the confirmability of the study. We strived not only for confirmation of our hypotheses, but also to challenge our pre-understandings and see the interpretations in a new light. Our pre-understanding was initially that existential loneliness would to some extent concern dying and the time before death. However, the results surprised us somewhat by showing the experience of existential loneliness in a wider perspective, as well as the barriers experienced by professionals. We were thus made aware of our initial prejudice and we were able to show our willingness to expand the horizon of meaning (Gadamer, Weinsheimer, \& Marshall, 2004; Nyström \& Dahlberg, 2001). In addition, the results have been presented and discussed in the research group as well as a reference group, both connected to the LONE study. The reference group has met twice during this time and the members have various experiences from health care, as a professional, informal carer, or relative.

\section{Conclusions}

Encountering existential loneliness is experienced by health care professionals as both challenging and meaningful, and it is important to talk about it and highlight its role in providing good-quality care to older people. It is demanding for health care professionals to encounter existential loneliness and to discuss issues such as the meaning of life, death, guilt, and regret, which prompt professionals to reflect upon existential aspects of their own lives. Consequently, the effects of facing existential loneliness do not seem to be limited to the caring situation, but rather to affect health care professionals both personally and professionally. Giving health care professionals time to reflect, both with their colleagues and alone, could increase their self-awareness and significantly improve the quality of care for older people in the later phases of their lives.

\section{Acknowledgments}

We are most grateful to all professionals who shared their experiences with us. A special thank you to the contact people in each care setting for their support and co- operation. We would also like to thank Helena Larsson for being helpful during data collection.

This study was accomplished within the context of the Swedish National Graduate School for Competitive Science on Ageing and Health (SWEAH) funded by the Swedish Research Council.

\section{Disclosure statement}

No potential conflict of interest was reported by the authors.

\section{Funding}

This work was supported by the [Vårdal Foundation]; under Grant [number 2014-0127]; [The Research Platform for Collaboration for Health at Kristianstad University] under Grant [number 3/2014], [9/2016]; [Crafoord Foundation] under Grant [number 2013-0841]; [Greta och Johan Kock Foundation] under Grant [number 2014-231-401] and [Gyllenstiernska Krapperup Foundation] under Grant [number 2013-00-16]

\section{Notes on contributors}

Malin Sundström, RN, is a PhD student in Caring Science at Faculty of Health and Society, Malmö University and the Research Platform for Collaboration for Health at Faculty of Health Science, Kristianstad University, Sweden.

Anna-Karin Edberg, RN, is a Professor in Nursing at the Research Platform for Collaboration for Health, Faculty of Health Science, Kristianstad University, Sweden.

Margareta Rämgård RN, is a senior lecturer in Care science and Human Geography, at Faculty of Health and Society, Malmö University, Sweden.

Kerstin Blomqvist RNt, is an Associate Professor in Nursing at the Research Platform for Collaboration for Health, Faculty of Health Science, Kristianstad University, Sweden.

\section{Author contribution}

M.S., A.-K.E., M.R. and K.B. designed the study. M.S., K.B. and M.R. collected the data. All authors analysed the data and prepared the manuscript.

\section{ORCID}

Malin Sundström (iD http://orcid.org/0000-0002-1284-3086 Anna-Karin Edberg (10) http://orcid.org/0000-0003-0161-4795 Margareta Rämgård (1) http://orcid.org/0000-0003-1235-620X Kerstin Blomqvist (i) http://orcid.org/0000-0002-4122-3003

\section{References}

Applebaum, F. (1978). Loneliness: A taxonomy and psychodynamic view. Clinical Social Work Journal, 6(1), 13-20.

Beauchamp, T., \& Childress, J. F. (2013). Principles of biomedical ethics. New York, NY: Oxford University Press.

Beck, I. (2013). Att fokusera på 'varandet' $i$ en värld av görande: Stöd till personal $i$ ett palliativt förhållningssätt vid vård-och omsorgsboende för äldre [To focus on 'being' 
in a world of doing. Support to nurse assistants in applying a palliative care approach in residential care for older people]. Lund: Department of Health Sciences, Lund University.

Buber, M. (1994). Jag och du [I and Thou]. Ludvika: Dualis Förlag.

Charmaz, K. (1983). Loss of self: A fundamental form of suffering in the chronically ill. Socialogy of Health and Illness, 5, 168-195.

Dahlberg, K. (2007). The enigmatic phenomenon of loneliness. International Journal of Qualitative Studies on Health and Well-Being, 2, 195-207.

Edberg, A.-K., \& Bolmsjö, I. (2017). Study protocol: Exploring existential loneliness among frail older people. The development phase of the LONE study. Manuscript submitted for publication.

Ericson-Lidman, E., Norberg, A., Persson, B., \& Strandberg, G. (2013). Healthcare personnel's experiences of situations in municipal elderly care that generate troubled conscience. Scandinavian Journal of Caring Sciences, 27, 215-223.

Ettema, E., Derksen, L., \& van Leeuwen, E. (2010). Existential loneliness and end of life care: A systematic review. Theoretical Medicine and Bioethics, 31(2), 141-169.

Finfgeld-Connet, D. (2008). Meta-synthesis of caring in nursing. Journal of Clinical Nursing, 17(2), 196-204.

Frankl, V. (2006). Livet måste ha mening: Erfarenheter från koncentrationslägren; logoterapins grundbegrepp [Man's Search for Meaning]. Stockholm: Natur och Kultur.

Gadamer, H.-G., Weinsheimer, J., \& Marshall, D. G. (2004). Truth and Method. London: Continuum.

Guba, E. G. (1981). Criteria for assessing the trustworthiness of naturalistic inquires. Educational Communication and Technology, 29(2), 75-91.

Hallberg, I. R. (2004). Death and dying from old people's point of view. A literature review. Aging Clinical and Experimental Research, 16(2), 87-103.

Halldórsdóttir, S., \& Hamrin, E. (1997). Caring and uncaring encounters within nursing and health care from the cancer patient's perspective. Cancer Nursing, 20(2), 120-128.

Harris, D. A. (2015). Lived-through past, experienced present, anticipated future: Understanding 'existential loss' in the context of life-limiting illness. Palliative and Supportive Care, 13, 1579-1594.

Hjelmblink, F., Bernsten, C. B., Uvhagen, H., Kunkel, S., \& Holmström, I. (2007). Understanding the meaning of rehabilitation to an aphasic patient through phenomenological analysis - A case study. International Journal of Qualitative Studies on Health and Well-Being, 2, 93-100.

Jaspers, K. (1994). Philosophy II. Illumination of existence. Munich: Piper.

Karnick, P. M. (2005). Feeling lonely: Theoretical perspectives. Nursing Science Quarterly, 18(1), 7-12.

Kirkevold, M., Moyle, W., Wilkinson, C., Meyer, J., \& Hauge, S. (2013). Facing the challenge of adapting to a life 'alone' in old age: The influence of losses. Journal of Advanced Nursing, 69(2), 394-403.

Krueger, R. A., \& Casey, M. A. (2009). Focus groups: A practical guide for applied research (4th ed.). London: SAGE.

Lindh, I.-B., Severinsson, E., \& Berg, A. (2009). Nurses' moral strength: $A$ hermeneutic inquiry in nursing practice. Journal of Advanced Nursing, 65(9), 1882-1890.

McCormack, B., \& McCance, T. (2010). Person-centred nursing: Theory and practice. Oxford: Wiley-Blackwell.

Mok, E., Lau, K., Lam, W., Chan, L., Ng, J., \& Chan, K. (2010). Health care professionals's perceptions of existential distress in patients with advanced cancer. Journal of Advanced Nursing, 66(7), 1510-1522.
MRC. (2008). Developing and evaluating complex interventions: New guidance. London: Medical Research Council.

Norell Pejner, M. (2013). The bright side of life. Support in municipal elderly home care. Örebro: School of Health and Medical Sciences, Örebro University.

Norell Pejner, M., Ziegert, K., \& Kihlgren, A. (2012). Trying to cope with everyday life - Emotional support in municipal elderly care setting. International Journal of Qualitative Studies of Health Well-Being, 7, 1-7.

Nyström, M. (2006). Aphasia - An existential loneliness: A study on the loss of the world of symbols. International Journal of Qualitative Studies on Health and Well-Being, 1, 38-49.

Nyström, M., \& Dahlberg, K. (2001). Pre-understanding and openess - A relationship without hope? Scandinavian Journal of Caring Sciences, 15, 339-346.

Polit, D., \& Beck, C. T. (2012). Nursing research: Generating and assessing evidence for nursing practice (9th ed.). Philadelphia, PA: Wolters Kluwer/Lippincott Williams \& Wilkins.

Ranheim, A. (2009). Caring and its ethical aspects - An empirical philosophical dialogue on caring. International Journal of Qualitative Studies on Health and Well-Being, 4, 78-85.

Sand, L., \& Strang, P. (2006). Existential loneliness in a palliative home care setting. Journal of Palliative Medicine, 9(6), 13761387.

Schreier, M. (2012). Qualitative content analysis in practice. London: SAGE.

Schuster, M. (2006). Profession och existens. En hermeneutisk studie av asymmetri och ömsesidighet $i$ sjuksköterskors möten med svårt sjuka patienter. [Profession and existence] Göteborg: Daidalos AB.

Severinsson, E. I. (2001). Confirmation, meaning and selfawareness as core concepts of the nursing supervision model. Nursing Ethics, 8(1), 36-44.

Strang, S., Strang, P., \& Ternestedt, B.-M. (2002). Spiritual needs as defined by Swedish nursing staff. Journal of Clinical Nursing, 11, 48-57.

Sundler, A. J., Eide, H., Van Dulmen, S., \& Holmström, I. K (2016). Communicative challenges in the home care of older persons: A qualitative exploration. Journal of Advanced Nursing, 1-10. doi:10.1111/jan.12996

Svanström, R., Sundler, A. J., Berglund, M., \& Westin, L. (2013). Suffering caused by care - Elderly patients' experiences in community care. International Journal of Qualitative Studies on Health and Well-Being, 8, 1-10.

Taylor, C. (2014). Boundaries in advanced nursing practice: The benefits of group supervision. Mental Health Practice, 17(10), 25-31.

Tillich, P. (1963). The eternal now. London: SCM Classics.

Todres, L., Galvin, K. T., \& Dahlberg, K. (2014). 'Caring for insiderness': Phenomenologically informed insights that can guide practice. International Journal of Qualitative Studies on Health and Well-Being, 9, 1-10.

Udo, C. (2014). The concept and relevance of existential issues of nursing. European Journal of Oncology Nursing, $18,347-354$

Udo, C., Danielson, E., \& Melin-Johansson, C. (2012). Existential issues among nurses in surgical care - A hermeneutical study of critical incidents. Journal of Advanced Nursing, 69(3), 569-577.

van Deurzen, E. (2012). Existential counselling \& psychotherapy in practice (3th ed.). London: SAGE.

Westin, L., \& Danielson, E. (2007). Encounters in Swedish nursing homes: A hermeneutic study of residents' experiences. Journal of Advanced Nursing, 60(2), 172-180.

Yalom, I. (1980). Existential psychotherapy. New York, NY Basic Books. 
II 



\title{
The context of care matters: Older people's existential loneliness from the perspective of healthcare professionals-A multiple case study
}

\author{
Malin Sundström ${ }^{1,2}$ (D) | Kerstin Blomqvist ${ }^{1}$ (D) | Anna-Karin Edberg ${ }^{1}$ (D) | \\ Margareta Rämgård ${ }^{2}$ (I)
}

${ }^{1}$ Research Platform for Collaboration for Health, Faculty of Health Science, Kristianstad University, Kristianstad, Sweden

${ }^{2}$ Faculty of Health and Society, Malmö University, Malmö, Sweden

Correspondence

Malin Sundström, Research Platform for Collaboration for Health, Faculty of Health Science, Kristianstad University, Kristianstad, Sweden.

Email: malin.sundstrom@hkr.se

Funding information

Greta och Johan Kock Foundation, Grant/ Award Number: 2014-231-401; The Research Platform for Collaboration for Health at Kristianstad University, Grant/ Award Number: 3/2014 and 9/2016; Crafoord Foundation, Grant/Award Number: 2013-0841; Vårdal Foundation, Grant/ Award Number: 2014-0127; Gyllenstiernska Krapperup Foundation, Grant/Award Number: 2013-00-16

\begin{abstract}
Aim: To explore existential loneliness among older people in different healthcare contexts from the perspective of healthcare professionals.

Background: Professionals meet and care for older people in most care contexts and need to be prepared to address physical, psychological, social and existential needs. Addressing existential loneliness can be both challenging and meaningful for professionals and is often not prioritised in times of austerity.

Design: A multiple case study design was used.

Methods: Focus group interviews were conducted with healthcare professionals $(n=52)$ in home, residential, hospital and palliative care settings. The analysis was performed in two steps: firstly, a within-case analysis of each context was conducted, followed by a cross-case analysis.

Findings: Differences and similarities were observed among the care contexts, including for the origin of existential loneliness. In home care and residential care, the focus was on life, the present and the past, compared to hospital and palliative care, in which existential loneliness mainly related to the forthcoming death. The older person's home, as the place where home care or palliative care was received, helped preserve the older person's identity. In hospital and palliative care, as in institutional care, the place offered security, while in residential care, the place could make older people feel like strangers. Creating relationships was considered an important part of the professionals' role in all four care contexts, although this had different meanings, purposes and conditions.

Conclusions: The context of care matters and influences how professionals view existential loneliness among older people and the opportunities they have to address existential loneliness.

Implications for practice: Support for professionals must be tailored to their needs, their education levels and the context of care. Professionals need training and appropriate qualifications to address existential loneliness related to existential aspects of ageing and care.
\end{abstract}


case study, context, existential loneliness, focus group, healthcare professional, older people, person-centred care

\section{1 | INTRODUCTION}

Old age is accompanied by physical and social losses that can lead to decreased psychological and existential well-being (Lloyd, Kendall, Starr, \& Murray, 2016). According to a systematic review by Hallberg (2004), older people need to talk about existential issues related not only to death, but also to their past and present lives as well as the future. In one study, patients in palliative home care settings expressed their wish that healthcare providers would address their existentia concerns (Sand \& Strang, 2006), and the authors concluded that neglect by healthcare providers may exacerbate patients' existential loneliness. Healthcare professionals who work with older people have reported encountering existential loneliness as a meaningful but challenging part of their work, and they have expressed insecurity, fear and even reluctance about encountering existential loneliness (Sundström, Edberg, Rämgård, \& Blomqvist, 2018). Moreover, healthcare professionals may have stereotyped beliefs of older people and their existential needs. If so, these beliefs and underlying assumptions need to become visible in order to improve care of older people. However, to provide high-quality care includes meeting both ethical and communicative challenges (Fagerberg \& Engström, 2012; Karlsson, Ekman, \& Fagerberg, 2009; Sundler, Eide, van Dulmen, \& Holmström, 2016). These challenges and their underlying factors might differ among care contexts and need to be further explored.

\section{BACKGROUND}

Existential loneliness has been defined as "the immediate aware ness of being fundamentally separated from other people and from the universe, and typically, because of this awareness, experiencing negative feelings, i.e., moods and emotions" (Bolmsjö, Tengland, \& Rämgård, 2018). In a review focused on existential loneliness in end-of-life care, Ettema, Derksen, and van Leeuwen (2010) showed that existential loneliness can be seen as a condition, an experience and a process of inner growth. Although the review indicated that existential loneliness can have positive connotations, a recent study of the meaning of existential loneliness among frail older people showed that existential loneliness mainly means being disconnected from life. This experience was related to being trapped in a frail body, being met with indifference, having no one to share meaningful aspects of life with, and lacking meaning in life (Sjöberg, Beck, Rasmussen, \& Edberg, 2017). In addition, the same frail older people may be cared for in several different contexts over a short period of time, and their existential loneliness may be met differently in each of them.

\section{What does this research add to existing knowledge in gerontology?}

- Shows that the context of care matters in relation to existential loneliness among older people in relation to its origin, the place and the role of professionals.

- Identifies professionals' need to be able to manage existential aspects related to the ageing body, life and death and to engage in existential conversations when appropriate.

- Sheds light on the importance of creating trustful relationships and their relevance to existential loneliness and the importance of trustful relationships within the staff group.

What are the implications of this new knowledge for nursing care of older people?

- Professionals require an awareness of place and the importance of finding moments to facilitate at-homeness regardless of whether care is provided in institutional care settings or in older people's homes.

- Professionals need to show interest in the older person and use empathetic curiosity rather than generalised perceptions of older people's existential needs to alleviate their existential loneliness.

How could the findings be used to influence policy or practice or research or education?

- The findings highlight the needs to support professionals in addressing existential loneliness and to provide time and opportunities for regular reflection on their practice regarding the existential aspects of care.

- The findings highlight that caring and trustful relations need to be acknowledged and supported by personcentred leadership that takes existential aspects and existential loneliness into account.

A study among nursing staff showed that nurses found holistic care to be important and that most considered spirituality an essential aspect of holistic care (Strang, Strang, \& Ternestedt, 2002) Spirituality has in turn been described as related to existential aspects of life (van Deurzen, 2012). It is not always easy, however for nurses to discover and be attentive to spiritual and existential concerns, as this requires both parties to be willing to share space (Minton, Isaacson, Varilek, Stadick, \& O'Connell-Persaud, 2018; 
Tornøe, Danbolt, Kvigne, \& Sørlie, 2015). A qualitative study by Sundström et al. (2018) showed that healthcare professionals experienced different barriers in their encounters with older people's existential loneliness that were related to their own feelings of insecurity and fear, to their abilities and possibilities, and to the concerns of the older person. There are certainly other aspects and factors that hinder or facilitate professionals in addressing existential loneliness, and these may differ among care contexts.

In many countries, care for older people is provided by different organisations and in different types of care settings. The type of organisation and the age of nurses have an impact on how nurses perceive the level of individualised care provided to older people, as higher age and sheltered housing compared to institutional care are associated with a higher level of individualised care (RodríguezMartín, Stolt, Katajisto, \& Suhonen, 2016). According to comparative studies in Canada, Germany, Japan and Sweden, there are countryspecific patterns and differences related to institutional frameworks and cultural values (Daly \& Szebehely, 2012; Theobald, Szebehely, Saito, \& Ishiguro, 2018). In addition, McCormack and McCance (2017) highlighted the care environment, including staff relationships and supportive organisational systems, as important elements of person-centred care. We lack knowledge, however, about whether and how addressing older people's existential loneliness is influenced by different factors in different contexts of care. Such knowledge is important for our ability to tailor direct support for healthcare staff to better address older people's existential needs and loneliness.

\subsection{Aim}

The aim of this study was to explore existential loneliness among older people in different healthcare contexts from the perspective of healthcare professionals.

\section{3 | METHODS}

\section{1 | Design}

This study is a part of the LONE study in which existential loneliness is explored through interviews with frail older people, their significant others, and healthcare professionals. In the LONE study, frail older people are defined as those aged $\geq 75$ years who receive long-term care from formal caregivers employed by the municipality or the county council, thereby covering most aspects of frailty as defined by Fried et al. (2001). This study focused on healthcare professionals and employed a multiple case study design with a holistic approach (Merriam \& Tisdell, 2016; Stake, 1995). According to Creswell (2007) and Merriam and Tisdell (2016), a multiple case study design is appropriate when investigating bounded systems, such as different contexts. The cases should, according to Stake (1995), be well defined. In this study, four contexts, home care, residential care, hospital care and palliative care, were viewed as bounded systems. Data were collected from 2015 to 2016 in southern Sweden through focus group interviews with healthcare professionals in different care settings and through individual telephone interviews with contact persons to collect contextual data about the settings. The analysis was performed in two steps, first using a within-case analysis of each case and then using a cross-case analysis (Creswell, 2007; Merriam \& Tisdell, 2016) focused on differences and similarities.

\section{2 | Care settings and participants}

Each care setting was purposively selected for its characteristics as a care context, including for variation settings in cities, small towns and rural areas. The inclusion criterion was that the setting should provide care for older people. Focus groups were conducted in home care $(n=2)$, residential care $(n=2)$, hospital care $(n=2)$ and palliative care $(n=3)$ settings. To obtain a variety of views and experiences, healthcare professionals $(n=52)$ with different professional backgrounds were selected (Table 1). Each care setting had a contact person connected to the LONE study who provided information about the study, received notifications of interest, and coordinated the date and place of the interview with one of the researchers (MS). Those who reported interest in participating were included in the study.

\section{3 | Data collection}

\subsection{1 | Focus group interviews}

Focus group interviews were used to collect qualitative data and obtain different viewpoints during focused discussions among the professionals (Brinkmann \& Kvale, 2015; Krueger \& Casey, 2015). The groups included three to eight participants and were conducted at the participants' work places. Before the focus group interviews, the participants were informed about the purpose of the study, assured that participation was voluntary, and advised of their right to withdraw at any time without explanation. Written consent was obtained. Each focus group interview began with an opening question about loneliness in general among older people. Existential loneliness was introduced with the following preamble and question:

We are particularly interested in a deeper feeling of being alone in life, sometimes called existential loneliness, a feeling that can come and go. Can you remember an experience with an older person who had this deeper kind of loneliness, of being alone in the world?

The focus group interviews proceeded with questions about existential loneliness and the professionals' experiences encountering existential loneliness among older people. The professionals were encouraged to discuss their experiences with each other and relate them to specific events and encounters. Followup questions were asked as needed. The role of the moderator (MS) was to lead the focus group, keep the conversation on track and ensure that everyone was as active in the discussion as they 
TABLE 1 Description of study participants in each care context

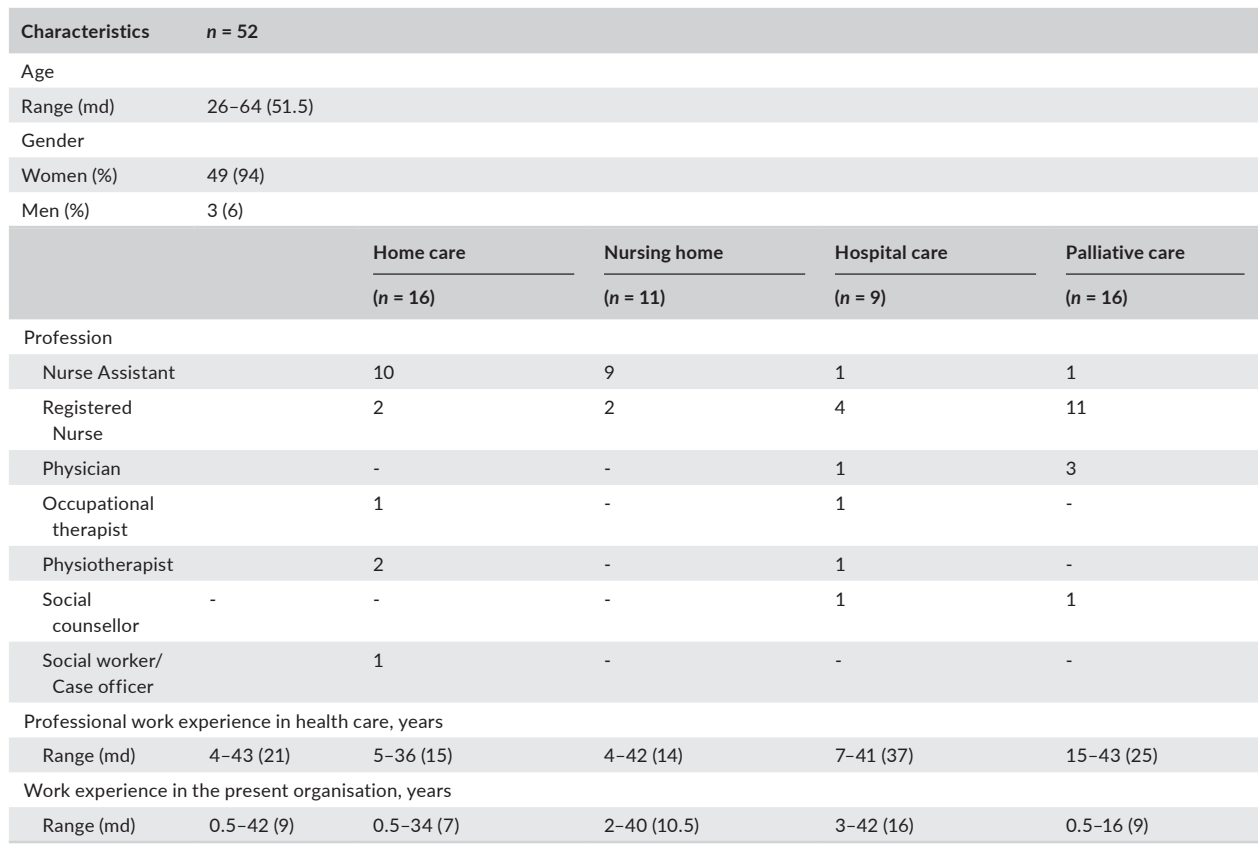

wished. The role of the observer (KB or MR) was to take notes and summarise the discussions before the focus group interview ended.

After each focus group interview, the participants answered a questionnaire about their age, work experience and profession. We had two hours at our disposal, including the initial introductions of the participants and the procedure. The focus group interviews ( $\mathrm{md}=1 \mathrm{hr} 41 \mathrm{~min}$ ) were audio recorded and transcribed verbatim by a trained transcriptionist. One recording that was interrupted by a technical problem was reconstructed from the notes and supplemented by a conversation between the moderator and the observer that was audio recorded immediately after the interview. Parts of the interview data that explored healthcare professionals' experiences of their encounters with older people's existential loneliness have been presented elsewhere (Sundström, Edberg, Rämgård, \& Blomqvist, 2018).

\subsection{2 | Telephone interviews}

Contextual information about each participating care setting was collected through telephone interviews in 2016. Before the interview, an email request with specific questions about the care setting was sent to each contact person. The information was collected conversationally, and notes were taken (MS). A summary of this information can be seen in Table 2 .

\section{4 | Analysis}

We used an inductive analytical approach conducted in two steps: a within-case analysis and a cross-case analysis (Creswell, 2007). In the first step, the within-case analysis, the text was read several times, context by context, by all four authors. From this reading, it seemed that the texts related to the following areas: (a) the professionals' views on the origin of existential loneliness; (b) the surroundings and the place where care was provided; and (c) relationships and the role of professionals in relation to older people's existential loneliness. The text related to the three identified themes was then re-read in depth to construct a "portrait" or story of each context (Merriam \& Tisdell, 2016). This part of the analysis was performed via discussions among the first, second and fourth authors, but the text for each case was critically reviewed by all four authors.

The second step, the cross-case analysis, focused on differences and similarities among the contexts concerning the origin, the place and the role of professionals. In this part of the analysis, the four cases were placed next to each other, and their content was compared and contrasted.

\section{5 | Ethical considerations}

According to the principle of respect for autonomy, it is important to allow potential participants time to consider whether they wish 
TABLE 2 Description of the care settings in the four cases

\begin{tabular}{|c|c|}
\hline \multicolumn{2}{|l|}{ Care settings } \\
\hline Home care settings & $\begin{array}{l}\text { The care settings in the home care case were in two towns of different } \\
\text { sizes, one urban and one rural. Care in those settings, with a few } \\
\text { exceptions, was provided to older people. Common diseases were } \\
\text { dementia, cardiovascular diseases, diabetes, and other diseases and } \\
\text { symptoms related to ageing. Other reported problems were social } \\
\text { isolation and loneliness. In addition to national laws and values, local } \\
\text { value systems were present and discussed during staff meetings. At } \\
\text { the local level, core values such as knowledge, a holistic approach and } \\
\text { a sense of security were highlighted, as were personal characteristics } \\
\text { such as creativity, courage and relational skills. Support in the form of } \\
\text { regular supervision or organised supervision focused on professionals' } \\
\text { own feelings and ways of working was lacking }\end{array}$ \\
\hline
\end{tabular}

Residential care settings

The care settings in the residential care case were in one city and a smaller town. Care was provided to older people exclusively, most of who were aged $\geq 90$ years. Comorbidities were common among the older people, and cardiovascular diseases and other age-related diseases were common. Depression was also common, as were symptoms of dementia, but these were often undiagnosed. In addition to national laws and values, local value systems were present, discussed during staff meetings and re-evaluated over time in staff groups. Examples of core values were respect, courage, diversity, sensitivity and consideration of others. One of the settings had a Christian profile, although professing the Christian faith was not a requirement for employment. Organised support and regular supervision for professionals challenged by encountering patients existential loneliness and related problems were lacking

Hospital care The two settings in the hospital care case were in the same hospital in settings an urban town. The care in the settings was provided to adults, most of whom were aged $70-80$ years. The care focused on medical and orthopaedic conditions, hospitalisation could be acute, and patients could be admitted through emergency services or planned admissions for more chronic conditions. In addition to national laws and values, county values included welcoming, motivating, being considerate of others, and respecting others. There was no formalised support for encountering existential issues. No regular supervision was offered

Palliative care
settings
different towns. The settings were separate both geographically and
managerially but were all part of the same county-level organisation.
Care was provided to patients of all ages in both urban and rural areas.
The most common diagnoses were advanced cancer, but the diagnoses
also included incurable heart disease, neurological diseases and
chronic obstructive pulmonary disease with severe symptoms. In
addition to national laws and values, county values were the same as
those in the hospital case: welcoming, motivating, being considerate of
others, and respecting others. The palliative care settings also
emphasised an approach that recognises a person's physical, spiritual,
existential and social needs. Professionals were offered regular clinical
supervision and organised meetings for reflection

to participate in research (Beauchamp \& Childress, 2013). As there were typically weeks between when the first information about the LONE study was sent and the time of the interview, appropriate time was considered to have been provided. Because the contact person could be a potential participant's colleague or manager, the voluntary nature of participating was repeated during the focus group introductions to reduce possible pressure. Questions about non-maleficence and beneficence were considered in relation to the interviews since discussions about existential loneliness might give rise to stress of conscience. Our experience, however, was that the participating professionals appreciated the opportunity to discuss existential loneliness and related issues. This study was approved by the Ethical Review Board, Lund, ref. 2014/652 as part of the LONE study.

\section{4 | FINDINGS}

The findings are presented as four cases, home care case, residential care case, hospital care case and palliative care case, followed by 
TAB LE 3 Description of home care, residential care, hospital care and palliative care in the Swedish context

\begin{abstract}
Home care context
Older people can apply for various kinds of support to help them live in their home for as long as possible. The home help officer conducts a needs assessment to decide the appropriate type of support for each applicant. Home help can include domestic services such as cleaning, laundry, and/or personal care and is mainly provided by nurse assistants and nurses who can also offer health care, including medication at home. Nurse assistants are available around the clock. Registered Nurses are available in the daytime and for consultations during evenings and overnight. If there is a need for a medical consultation, the physician (GP) is available during the day, and a GP is on call evenings, nights and weekends. Occupational and physical therapists may also be involved

Hospital care context

Admittance to hospital care is through the hospital emergency service or planned hospitalization. Older patients' hospital stays vary in length depending on the cause from a couple of days to a week or two. Swedish legislation requires that a plan for ongoing care be in place before discharge. The care is planned mainly through collaboration between the hospital and municipality, but primary care and the GP at the local health centre are also involved in the discharge and must agree to take over medical responsibility for the older person before discharge. Physicians, Registered Nurses, and nurse assistants are available around the clock; social counsellors and occupational and physical therapists are available during the day
\end{abstract}

\section{Residential care context}

When an older person's needs can no longer be provided at home, residential facilities provide health and social care, and some specialise in dementia care. Access to residential care requires a decision from the home help officer and can be initiated during discharge planning at the hospital or through an application from the older person living at home or the person's relatives. Care in residential homes is mostly provided by nurse assistants who are available around the clock. Registered Nurses are available in the daytime and for consultations during evenings and overnight. A GP is available at the local healthcare centre during the day and on call evenings, nights and weekends. Occupational and physical therapists are involved in care either directly or by providing technical aids and assessments

\section{Palliative care context}

Specialised palliative care requires a remittance from the older person's physician and a medical assessment. If the older person is assessed to be in need of specialised palliative care, it is provided in the patient's home or in specialised live-in units. The organisation offers physicians, Registered Nurses, and nurse assistants around the clock, and social counsellors and occupational and physical therapists are available on weekdays. Specialised palliative care can be provided solely by the palliative organisation, or it can be provided in collaboration with the municipality in conjunction with home care or residential care the findings of the cross-case analysis. A deeper description of the context of care for each case is shown in Table 3. Quotations are provided as illustrative examples; see Table 4.

\subsection{Home care case}

Home care professionals perceived that the origin of older people's experiences of existential loneliness was related to missing their previous life, no longer feeling needed, being unable to live independently and meaningfully in their own homes and feeling that their children had no time to visit. Existential loneliness was also perceived to arise when people from their own time and generation were gone and they had no one left with whom to share memories, thoughts, values and important life events (Table 4). The professionals perceived that existential loneliness was associated with death, but they rarely talked about death with the people in their care.

The home care professionals experienced that home, as a place, helped preserve people's identity even when their functioning decreased, but it could also cause existential loneliness if people felt trapped by their inability to venture outside their home. The professionals used an expression that translates as "if you are not visible to others, you don't exist" to describe the effect of homebound isolation. The professionals also perceived people who had moved at older ages as rootless in an existential sense. According to the professionals, the care provided in older people's homes was personalised to accommodate the older people's own values and wishes. The professionals recognised the importance of the home to older people's identity and self-esteem, which affected their way of working, and they articulated the risk of the home becoming organised as a workplace to meet the needs of the professionals rather than the needs of the older people (Table 4). The professionals also believed that spending time outside could promote existential conversations and give life a different dimension by observing nature's changes, meeting neighbours and seeing other people.

The home care professionals emphasised that being honest and present during encounters was an essential part of their role in the relationship with the older person. Other aspects of that relationship were asking questions, taking time to listen, and giving the person time to tell their stories fully rather than just chat. However, courage was required to endure existential encounters. The professionals described the importance of being able to "step out of themselves" (Table 4). When they visited regularly, the professionals were often invited to share the older person's thoughts about meaning, life and existential issues, and they believed that knowing more about the person facilitated such conversations.

\section{2 | Residential care case}

Residential care professionals perceived that the main origin of existential loneliness in older people was the painful loss of important people in their lives. These professionals also felt that poor relationships between older people and their relatives could lead to existential loneliness, and existential loneliness was associated with feelings of alienation (Table 4). Diseases and disabilities were described as causing a feeling among older people of being strangers to themselves when they could no longer do what they previously enjoyed or when they could not cope with everyday situations. Existential loneliness was, according to the residential 
care professionals, associated with the resident's approaching death. Existential conversations among the professionals themselves on topics such as what was going to happen after death were unusual in residential care.

The residential care professionals said that the unit, as a place, could make an older person feel like a stranger in a strange land. These professionals believed that the residential community and activities could alleviate existential loneliness, but they also described how some residents wanted to be alone in their rooms (Table 4). Meanwhile, other residents constantly sought the company of the residential care professionals. Although the professionals believed that dialogue about meaningful matters could relieve existential loneliness, they had to prioritise among tasks and among the individual needs, wishes and requirements of each person in their care. On the other hand, the professionals also said that such encounters need not necessarily be long. Instead, when the pace slowed and time was available, conversations about existential matters were possible.

The residential care professionals said that being able to meet person to person instead of employee to resident was an important part of their role when addressing existential loneliness. These professionals described the importance of showing consideration and building relationships to reduce existential loneliness, and touch was perceived as especially valuable and relationship-creating. Some professionals tried to redirect existential conversations and did not feel comfortable talking about existential issues, while others said such conversations were important. Professionals who had experience talking about existential issues emphasised the importance of continuing to ask questions to understand, but they also described trying to change the subject when death or dying came up. Since many of the residents needed the help of two carers, the staff often worked in pairs, and this was seen as a limitation that could make it harder to capture existential concerns (Table 4). When professionals in residential care perceived a resident as being lonely, they often tried to pair residents, but this was not always appreciated.

\subsection{Hospital care case}

Hospital care professionals did not reflect on the origin of existential loneliness or ask older patients about their existential concerns. These professionals perceived younger and middle-aged patients to have a more urgent need to talk about their loneliness, existential concerns and situation in the hospital than older patients. Hospital care professionals felt that existential loneliness was related to the end of life and that feelings of existential loneliness were hard to put into words. "How much time is left [for the patient]?" was a common question from older patients' relatives and was typically answered with standard phrases. The professionals believed that it was important for everyone near death to have someone at their side and experienced it as a failure when a patient died alone. It was not unusual for older patients to "ask for an injection to fall asleep," and the professionals suggested that this may be a sign of existential loneliness
(Table 4). However, some of the professionals wished that talking about existential issues could be a natural part of hospital care.

According to the professionals, the hospital, as a place, offered security and a temporary community for older persons who lived alone. Although the reason for a hospital stay was often an acute illness, seeking hospital care could be an expression of loneliness at home. These professionals described older patients who complained about new symptoms or were reluctant to undergo rehabilitation as showing signs of reluctance to return to their lonely homes (Table 4). Stress and the quick pace in the hospital were perceived as barriers to picking up signals of patients' existential concerns and hindering reflections about existential loneliness. The hospital care professionals experienced few opportunities for private conversations with older patients but described how privacy, designated time together, and physical contact could make conversations easier, for example, while assisting with personal hygiene.

The professionals described their own role in encountering existential loneliness in hospital care as limited, partly because they did not think they could support them in existential matters. They saw only a small part of an older person's life, and short hospital stays and lack of continuity were perceived to hinder relationship building and trust. The professionals stressed the importance of using body language to promote a positive encounter by, for instance, sitting down with patients to express that "it is only you and me right here, right now." The professionals noted that older patients might avoid expressing their concerns and needs when professionals seem busy and stressed (Table 4). However, instead of showing openness to engaging in conversations about existential matters, the professionals chose to end the conversation. Sensitivity to personal losses and an interest in the existential aspects of death were considered personal skills, but neither general nor existential loneliness was typically explored.

\subsection{Palliative care case}

Palliative care professionals thought the origin of existential loneliness was primarily linked to death, and they described existential loneliness as an inescapable feeling that comes from within (Table 4). Palliative care professionals highlighted the importance of hope and consolation in times of uncertainty at the end of life. These professionals expressed perceptions that existential loneliness at the end of life was more common among middle-aged people and that older people were typically content with life. The professionals cited a lack of physical contact as one origin of existential loneliness and the sense of being abandoned, which was expressed by the person wanting to hold hands or seeking closeness to feel the presence of another person.

The palliative care professionals felt that the home, as a place, could provide security, but this could change when relationships within the family were no longer functional. When palliative care was provided at home, professionals used clues such as photographs, paintings and books to learn out about the older person's life, important relationships and interests (Table 4). The hospice unit 
TAB LE 4 Quotations from the four cases

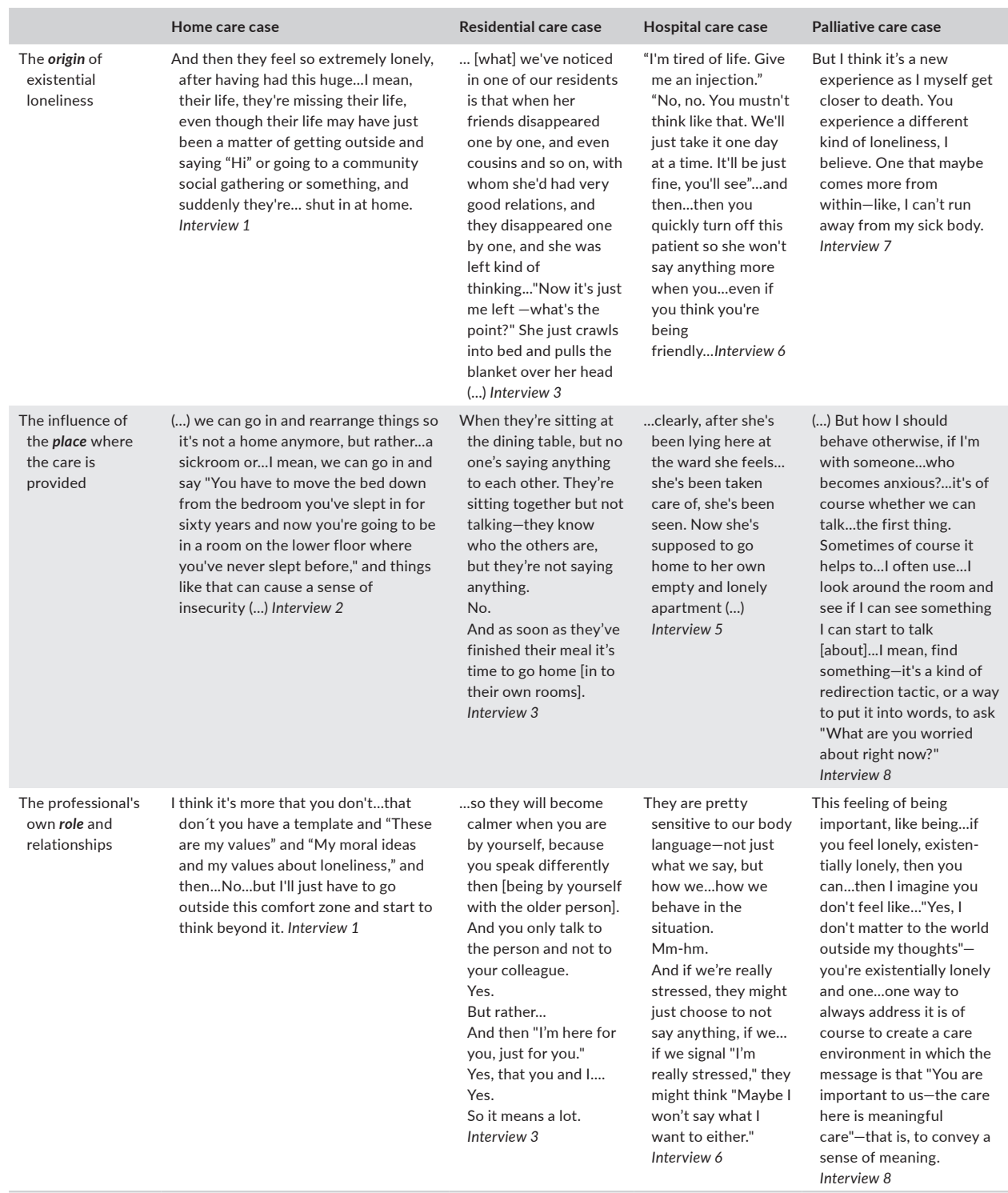

was perceived to provide security due to the continuous presence of the staff. As a place, however, the hospice unit was for some patients a reminder that they could never go home again. In addition, the palliative care professionals emphasised the centrality of relationships, regardless of whether care was given at home or in the hospice.
The palliative care professionals believed that their role was to create meaningful relationships. It was important to these professionals to convey to every person they cared for that he/she was still important despite any loss of function or need for help. These professionals also said that being considerate of patients' feelings and 
sharing thoughts and feelings about meaning and guilt could help relieve the patients' existential loneliness, at least for a little while (Table 4). The professionals described how empathetic curiosity could be used to open existential conversations in order to connect and alleviate existential loneliness. While some of the professionals viewed themselves as tools in the encounter and described being present, listening and having the courage to talk about existential matters as essential to their work, others described talking about existential issues as belonging to their own private sphere and said that they avoided existential conversations with patients for that reason. The professionals emphasised the importance of being able to adjust the pace and depart from routines to allow the older person control and prioritise what happened. Physical touch, not having to make eye contact, and moments of silence were described as providing openings for existential talks. The professionals also perceived that older people were more likely to share their stories than younger people. The contours of the older persons' lives and their concerns became clearer when they were allowed to narrate their own stories, which was seen as particularly important during times of illness and weakness.

\section{5 | Cross-case analysis}

In home care and residential care, the institutional intent was to provide and enable meaningful everyday lives for patients, while in hospital care the goal was to cure patients, with a focus on their discharge. In palliative care, the aim was to provide a high-quality end of life. The differences and similarities among the cases are presented in relation to the origin of existential loneliness, the influence of the place where the care is provided and the role of professionals.

There were differences in how the professionals in different care contexts viewed and interpreted the origin of existential loneliness, even though existential loneliness was related to death in all four contexts to various degrees. While the home care professionals perceived that the inability to live an independent life and missing people from one's own generation as the primary reason for existential loneliness, the residential care professionals described the main reason for existential loneliness as the loss of the social network, poor relationships with relatives and the loss of friends who had passed away. Thus, in these two care contexts, existential loneliness was perceived not only as something related to death but also as something related to the past or present life. The hospital and palliative care professionals mainly spoke about death, and these professionals expressed how imminent death could cause experiences of existential loneliness. Finally, palliative care and residential care professionals described that feeling like a stranger to oneself and one's own body was a cause of existential loneliness, and this was primarily related to disease and disability.

There were differences among the contexts concerning the place of care. When care was provided in older persons' own homes, the home as a place helped preserve the person's identity, while the place was considered to offer security in institutional care such as hospitals and hospice units, and in residential care. There were, however, contradictions when care was provided at home. On the one hand, both the home care and palliative care professionals expressed that the home primarily helped preserve the older person's identity. On the other hand, the home care professionals also described the home as isolating, while the palliative care professionals expressed that the home could affect the older person negatively when family relationships were strained. The ability of the place to offer security was described by professionals working in hospital care, palliative care and residential care, but contradictions were also observed in these contexts. The hospital ward could hinder existential conversations due to a lack of private spaces, and the hospice unit could, while offering security, be a reminder that the person would never go home again. In residential care, the resident's own room could be perceived as a sanctuary, while the common areas, such as the dining room, could contribute to a feeling of being a stranger in a strange land.

Creating relationships was considered an important part of the professionals' role in all four care contexts, although this had different meanings, purposes and conditions. According to home care and residential care professionals, their role was to facilitate and maintain relationships with significant others or to pair residents with each other to support a social context as a means to alleviate existential loneliness. The home care professionals highlighted that their role was to create relationships and emphasised the importance of listening to the older persons' stories and narratives. The residential care professionals, however, highlighted the importance of interacting person to person but felt limited due to their working conditions and their uncertainty about discussing existential matters. Concerning hospital care, the main constraints were short hospital stays and a lack of continuity that limited the professionals in relationship building. Finally, in palliative care, it was fundamental to create meaningful relationships and to convince the older persons that they were still important regardless of their capacity or need for help, and existential conversations were considered a central part of the professionals' job.

\section{5 | DISCUSSION}

According to our findings, the context of care matters. Context is "the setting in which practice takes place" (McCormack et al., 2002), but the care setting is also a place. The place affects people, and people in turn affect the place. Here, place is considered an area of space given meaning through personal, social and cultural processes (Low \& Altman, 1992). Place also affects professionals' interpretation of older people's existential loneliness, which has implications for care, as care can be provided in both institutional care settings and one's own home. Feeling at home is important in all phases of life, but the increasing frailty of old age implies an increased vulnerability that makes feeling at home even more important and challenging (Cuthin, 2013). An important aspect of care and combatting existential loneliness is therefore to facilitate at-homeness and enable older people 
to withdraw when they need to do so. "At-homeness" is related to feeling safe, being connected and being centred (Öhlén, Ekman, Zingmark, Bolmsjö, \& Benzein, 2014). The concept of at-homeness is also relevant in institutions, such as residential and hospital care, where private spaces can be difficult to create. It is, however, important to remember that even the patient's own home carries a risk of shifting from a private to a public space when it becomes a care setting, and this can have consequences for the older person's meaning of home and lead to his/her displacement in his/her home space (Milligan, 2003) and to existential loneliness.

Listening to older people's stories seems to be essential for professionals' ability to understand the people in their care. Our findings showed that the time and space for deeper conversations differed among the contexts. While a shortage of time was described as a major limiting factor in hospital and residential care, existential conversations were considered fundamental and prioritised in the palliative care context. The shortage of time seemed to be an important consideration in times of austerity and cutbacks in the healthcare sector, as time with people in care can be limited, and time for reflection with colleagues can be difficult to create. This finding is in line with earlier research in which nurse assistants in residential care described the conflict of having to prioritise "doing" over "being" (Beck, Törnquist, Broström, \& Edberg, 2012) and home care assistants requested regular meetings with colleagues for support (Craftman, Grundberg, \& Westerbotn, 2018). Existential conversations require time, as they rely on authenticity and the "I/Thou" relationship described by Buber (1994), which is based on equality, genuine interest in the other person, and reciprocity. However, authentic encounters require sharing silence and time. Sharing silence with someone could be a way to find peace and a moment of relief from suffering, especially in situations when words may fail (Bassett, Bingley, \& Brearley, 2018), and might alleviate existential loneliness. Nevertheless, a shortage of time poses challenges for staff, especially in hospital care.

However, a lack of time is not the only explanation for why existential conversations are rare. Our findings that show that nurses' perceived need for courage, discomfort about discussing existential matters, and felt inability to support patients' existential concerns were other explanations. This is in line with a study on communication about existential issues in which nurses expressed that unwillingness to talk about existential matters can also be attributed to insecurity and lack of training (Strang, Henoch, Danielson, Browall, \& Melin-Johansson, 2014). However, in palliative care, existential conversations were considered a central part of the professionals' job. One thing that differs between the four contexts in this study is that the professionals in palliative care were offered regular clinical supervision and organised meetings for reflection. In addition, the palliative care settings emphasised an approach that recognised existential needs to be as essential as physical, social and spiritual needs. This highlights the importance of both allowing professionals the opportunity to talk with patients about existential matters and an explicit value system of care that includes existential concerns. Professionals in both hospital and palliative care perceived that existential loneliness and concerns were more common among younger and middle-aged persons than among older persons. This indicates that older peoples' existential needs and concerns may be neglected or downplayed. Thus, support for professionals to feel more confident in addressing existential loneliness and improvements in care settings need to be tailored to suit the specific setting and context of care.

Creating trustful relationships was considered important in all the care contexts, but working conditions and routines were hindering factors. Person-centred care implies adjusting care routines to each person's need for interpersonal relations and to fulfil his/her socia needs. To attain this goal, there is a need for flexibility in the organisation to allow professionals to personalise the care they provide to older people. There is also a need to provide professionals with opportunities and time for regular reflection on the existential aspects of that care. In addition, the importance of leadership and its impact on person-centred care and the psychosocial climate should be highlighted (Backman, Sjögren, Lindkvist, Lövheim, \& Edvardsson, 2016). Such leadership should also be person-centred, using a coaching approach and direct feedback to focus on improving professionals' capacities and allow them to push normal boundaries when necessary (Backman, Sjögren, Lindkvist, Lövheim, \& Edvardsson, 2017). Finally, professionals' opportunities to create trustful relationships need to be supported by leaders who consider existential aspects of caring in general and existential loneliness in particular.

\section{1 | Methodological considerations}

Even if each defined context in this study consisted of two or three settings with both differences and similarities, there is a risk of creating a simplified image of each context. This complexity of contexts may affect both the credibility and the transferability of our findings, but we believe that the variation in the professions within the four contexts reflects the true professional composition of the staff in the various contexts. During focus groups, participants might risk disclosing their personal shortcomings, but our impression was that instead, sharing their experiences and stories inspired and encouraged them. Accordingly, we believe this gave rise to further reflections on existential loneliness in relation to practice. This was also the case in focus groups with less than five participants, although Krueger and Casey (2015) recommend five to eight participants. Because one of the recordings was interrupted, there is a risk that important data were lost. However, the missing part was at the beginning of one of two interviews at the same care context. As the interview was reconstructed directly by the interviewers, we believe that potential loss of data had no major impact on the trustworthiness of the findings.

Although field notes are a typical data source in case study research (Creswell, 2007; Stake, 1995), we did not take such notes during the data collection, and this might be a weakness. We be lieve, however, that the professionals provided important clues and knowledge about existential loneliness among older people and the impact of context on their perceptions of loneliness. To achieve 
credibility, we collected information about each of the care settings to better understand and describe each context. An adequate contextual description is important to understanding any setting in a case study (Hyett, Kenny, \& Dickson-Swift, 2014), therefore, local descriptions based on the telephone interviews are provided.

\section{6 | CONCLUSION}

The context of care matters and influences how professionals view existential loneliness among older people and the opportunities they are offered to address existential loneliness. Further, existential loneliness needs to be considered in relation to the care environment and the specific care provided. The contexts' different purposes most certainly influence professionals' opportunities and abilities to focus on patients' existential concerns. It seems necessary to provide opportunities for structured reflection on existential matters and other phenomena relevant to caring, such as meaning, hope and consolation, based on professional's own experiences. To increase professionals' confidence in addressing existential loneliness, the support must be tailored to the specific setting and context of care. Professionals' opportunities to create trustful relationships also need to be supported by person-centred leadership focused on expanding their capacities.

\section{Implications for practice}

- As older peoples' existential needs and concerns may be neglected or downplayed, professionals need training and appropriate qualifications to address existential aspects of ageing and care.

- Support to professionals to feel more confident in addressing existential loneliness needs to be tailored to the context of care.

- Professionals' opportunities to create trustful relationships need to be supported by leaders who consider existential aspects of caring in general and existential loneliness in particular.

\section{ACKNOWLEDGEMENTS}

We are most grateful to all professionals for generously sharing thei experiences, to the contact person in each care setting for their help and co-operation, to the LONE research group, to the reference group for their valuable input, and to Proper English $A B$ and Wiley Editing Services for language revision. This study was accomplished within the context of the "Swedish National Graduate School for Competitive Science on Ageing and Health" (SWEAH) funded by the Swedish Research Council.

\section{AUTHOR CONTRIBUTIONS}

MS, KB, AKE and MR contributed to the design. MS and KB or MR collected the focus group interviews. The analysis was made by MS,
$K B, A K E$ and $M R$. MS wrote the initial draft of the manuscript and $K B$, $A K E$ and MR commented critically and contributed substantially to the manuscript. All authors read and approved the final manuscript.

\section{ORCID}

Malin Sundström (iD https://orcid.org/0000-0002-1284-3086

Kerstin Blomqvist (D) http://orcid.org/0000-0002-4122-3003

Anna-Karin Edberg (D) https://orcid.org/0000-0003-0161-4795

Margareta Rämgård (D) http://orcid.org/0000-0003-1235-620X

\section{REFERENCES}

Backman, A., Sjögren, K., Lindkvist, M., Lövheim, H., \& Edvardsson, D. (2016). Towards person-centredness in care - exploring the impact of leadership. Journal of Nursing Management, 24, 766-774. https://doi. org/10.1111/jonm.12380

Backman, A., Sjögren, K., Lindkvist, M., Lövheim, H., \& Edvardsson, D. (2017). Characteristics of highly rated leadership in nursing homes using item response theory. Journal of Advanced Nursing, 73(12), 2903-2913. https://doi.org/10.1111/jan.13353

Bassett, L., Bingley, A. F., \& Brearley, S. G. (2018). Silence as an element of care: A meta-ethnographic review of professional caregivers' ex perience in clinical and pastoral settings. Palliative Medicine, 32, 185 194. https://doi.org/10.1177/0269216317722444

Beauchamp, T. L., \& Childress, J. F. (2013). Principles of biomedical ethics, 7th ed. New York, NY: Oxford University Press.

Beck, I., Törnquist, A., Broström, L., \& Edberg, A. K. (2012). Having to focus on doing rather than being-nurse assistants' experience of palliative care in municipal residential care settings. International Journal of Nursing Studies, 49, 455-464. https://doi.org/10.1016/j. ijnurstu.2011.10.016

Bolmsjö, I., Tengland, P. A., \& Rämgård, M. (2018). Existential loneliness: An attempt at an analysis of the concept and the phenomenon. Nursing Ethics, 096973301774848. [Epub ahead of print]. https://doi. org/10.1177/0969733017748480

Brinkmann, S., \& Kvale, S. (2015). InterViews: Learning the craft of qualitative research interviewing. Los Angeles, CA: Sage Publications.

Buber, M. (1994). I and thou [In Swedish: Jag och du]. Ludvika, Sweden Dualis.

Craftman, A. G., Grundberg, A., \& Westerbotn, M. (2018). Experiences of home care assistants providing social care to older people: A context in transition. International Journal of Older People Nursing., 13(4) e12207. https://doi.org/10.1111/opn.12207

Creswell, J. W. (2007). Qualitative inquiry \& research design: Choosing among five approaches, 2 nd ed. Thousand Oaks, CA: SAGE.

Cuthin, M. P. (2013). The complex process of becoming at-home in assisted living. In G. D. Rowles, \& M. Bernard (Eds.), Environmental gerontology: Making meaningful places in old age (pp. 105-123). New York, NY: Springer.

Daly, T., \& Szebehely, M. (2012). Unheard voices, unmapped terrain: Care work in long-term residential care for older people in Canada and Sweden. International Journal of Social Welfare, 21, 139-148. https:// doi.org/10.1111/j.1468-2397.2011.00806.x

Ettema, E. J., Derksen, L. D., \& van Leeuwen, E. (2010). Existential loneliness and end-of-life care: A systematic review. Theoretical Medicine and Bioethics, 31, 141-169. https://doi.org/10.1007/s11017-010-9141-1

Fagerberg, I., \& Engström, G. (2012). Care of the old-A matter of ethics, organization and relationships. International Journal of Qualitative Studies on Health and Well-being, 7, https://doi.org/10.3402/qhw. v7i0.9684 
Fried, L. P., Tangen, C. M., Walston, J., Newman, A. B., Hirsch, C., Gottdiener, J., ... Cardiovascular Health Study Collaborative Research, G. (2001). Frailty in older adults: Evidence for a phenotype. The Journals of Gerontology Series A: Biological Sciences and Medical Sciences, 56(3), 146-157. https://doi.org/10.1093/gerona/56.3.M146

Hallberg, I. R. (2004). Death and dying from old people's point of view. A literature review. Aging Clinical and Experimental Research, 16(2), 87-103. https://doi.org/10.1007/BF03324537

Hyett, N., Kenny, A., \& Dickson-Swift, V. (2014). Methodology or method? A critical review of qualitative case study reports. International Journal of Qualitative Studies on Health and Well-being, 9(1), 23606. https://doi.org/10.3402/qhw.v9.23606

Karlsson, I., Ekman, S. L., \& Fagerberg, I. (2009). A difficult mission to work as a nurse in a residential care home - some registered nurses' experiences of their work situation. Scandinavian Journal of Caring Sciences, 23, 265-273. https://doi.org/10.1111/j.1471-6712.2008.00616.x

Krueger, R. A., \& Casey, M. A. (2015). Focus groups: A practical guide for applied research, 5th ed. Thousand Oaks, CA: Sage.

Lloyd, A., Kendall, M., Starr, J. M., \& Murray, S. A. (2016). Physical, social, psychological and existential trajectories of loss and adaptation towards the end of life for older people living with frailty: A serial interview study. BMC Geriatrics, 16, https://doi.org/10.1186/ s12877-016-0350-y

Low, S. M., \& Altman, I. (1992). Place attachment: A conceptual inquiry. In I. Altman, \& S. M. Low (Eds.), Place attachment (pp. 1-12). New York, NY: Springer

McCormack, B., Kitson, A., Harvey, G., Rycroft-Malone, J., Titchen, A. \& Seers, K. (2002). Getting evidence into practice: The meaning of 'context'. Journal of Advanced Nursing, 38(1), 94-104. https://doi. org/10.1046/j.1365-2648.2002.02150.x

McCormack, B., \& McCance, T. (2017). Person-centred practice in nursing and health care: Theory and practice, 2nd ed. Oxford, UK Wiley-Blackwell.

Merriam, S. B., \& Tisdell, E. J. (2016). Qualitative research: A guide to design and implementation, 4th ed. San Francisco, CA: Jossey-Bass.

Milligan, C. (2003). Location or dis-location? Towards a conceptualization of people and place in the care-giving experience. Social \& Cultural Geography, 4, 455-470. https://doi. org/10.1080/1464936032000137902

Minton, M. E., Isaacson, M. J., Varilek, B. M., Stadick, J. L., \& O'ConnellPersaud, S. (2018). A willingness to go there: Nurses and spiritual care. Journal of Clinical Nursing, 27(1-2), 173-181. https://doi. org/10.1111/jocn.13867

Öhlén, J., Ekman, I., Zingmark, K., Bolmsjö, I., \& Benzein, E. (2014). Conceptual development of "at-homeness" despite illness and disease: A review. International Journal of Qualitative Studies on Health and Well-being, 9, 23677. https://doi.org/10.3402/qhw.v9.23677

Rodriguez-Martín, B., Stolt, M., Katajisto, J., \& Suhonen, R. (2016). Nurses' characteristics and organisational factors associated with their assessments of individualised care in care institutions for olde people. Scandinavian Journal of Caring Sciences, 30, 250-259. https:// doi.org/10.1111/scs.12235

Sand, L., \& Strang, P. (2006). Existential loneliness in a palliative home care setting. Journal of Palliative Medicine, 9(6), 1376-1387. https:// doi.org/10.1089/jpm.2006.9.1376

Sjöberg, M., Beck, I., Rasmussen, B. H., \& Edberg, A. K. (2017). Being disconnected from life: Meanings of existential loneliness as narrated by frail older people. Aging \& Mental Health, 22(10), 1357-1364 https://doi.org/10.1080/13607863.2017.1348481

Stake, R. E. (1995). The art of case study research. Thousand Oaks, CA Sage.

Strang, S., Henoch, I., Danielson, E., Browall, M., \& Melin-Johansson, C. (2014). Communication about existential issues with patients close to death - nurses' reflections on content, process and meaning. Psycho-Oncology, 23, 562-568. https://doi.org/10.1002/ pon. 3456

Strang, S., Strang, P., \& Ternestedt, B. M. (2002). Spiritual needs as defined by Swedish nursing staff. Journal of Clinical Nursing, 11(1), 48 57. https://doi.org/10.1046/j.1365-2702.2002.00569.x

Sundler, A. J., Eide, H., van Dulmen, S., \& Holmström, I. K. (2016). Communicative challenges in the home care of older persons - a qualitative exploration. Journal of Advanced Nursing, 72, 2435-2444. https://doi.org/10.1111/jan.12996

Sundström, M., Edberg, A. K., Rämgård, M., \& Blomqvist, K. (2018) Encountering existential loneliness among older people: Perspectives of health care professionals. International Journal of Qualitative Studies on Health and Well-being, 13(1), 1474673. https://doi.org/10 $.1080 / 17482631.2018 .1474673$

Theobald, H., Szebehely, M., Saito, Y., \& Ishiguro, N. (2018). Marketisation policies in different contexts: Consequences for home-care workers in Germany, Japan and Sweden. International Journal of Social Welfare, 21, 139-148. https://doi.org/10.1111/ijsw.12298

Tornøe, K. A., Danbolt, L. J., Kvigne, K., \& Sørlie, V. (2015). The challenge of consolation: Nurses' experiences with spiritual and existentia care for the dying-a phenomenological hermeneutical study. BMC Nursing, 14, https://doi.org/10.1186/s12912-015-0114-6

van Deurzen, E. (2012). Existential counselling \& psychotherapy in practice. London, UK: SAGE.

How to cite this article: Sundström M, Blomqvist K, Edberg A-K, Rämgård M. The context of care matters: Older people's existential loneliness from the perspective of healthcare professionals-A multiple case study. Int J Older People Nurs. 2019;14:e12234. https://doi.org/10.1111/opn.12234 


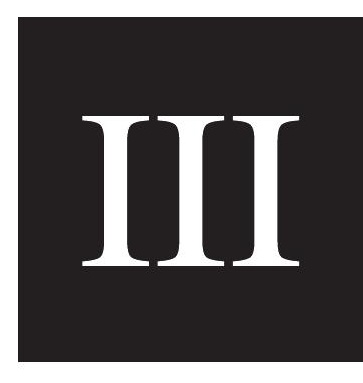



Being a volunteer encountering older people's loneliness and existential loneliness: Alleviating loneliness for others and oneself

Malin Sundström, RN, MSc, ${ }^{1,2}$ Kerstin Blomqvist, RNt, $\mathrm{PhD},{ }^{1}$ Anna-Karin Edberg, RN, $\mathrm{PhD}^{1}$

${ }^{1}$ Research Platform for Collaboration for Health, Faculty of Health Science, Kristianstad University, Kristianstad, Sweden

${ }^{2}$ Faculty of Health and Society, Malmö University, Malmö, Sweden

\section{Corresponding author}

Malin Sundström

Kristianstad University

SE-291 88 Kristianstad

+46442503879

malin.sundstrom@hkr.se 


\begin{abstract}
Background

The increasing proportion of older people worldwide is challenging society and the healthcare sector to develop new solutions, such as involving volunteers, especially to combat loneliness among older people. Loneliness is a broad concept comprising, for example, existential loneliness - a deep feeling of aloneness in the world. We know little about volunteers' experience of encountering older people's loneliness in general and existential loneliness in particular. Such knowledge is important in order to develop high-quality volunteering.
\end{abstract}

\begin{abstract}
Aim
This study aimed to describe volunteers' experience of becoming and being a volunteer, and encountering older people's loneliness in general and existential loneliness in particular.

\section{Methods}

This descriptive qualitative study is based on eight focus group interviews and twelve individual interviews with volunteers from different organisations, analysed using conventional content analysis.
\end{abstract}

\title{
Findings
}

Being a volunteer meant being a fellow human being, alleviating loneliness for others and oneself. Becoming a volunteer was a way of finding meaning, and volunteering made the volunteers feel rewarded and simultaneously emotionally challenged. Being a volunteer also meant acting on one's values, challenging boundaries when necessary. Encountering loneliness, including existential loneliness, required sensitivity to others' needs for both closeness and distance.

\section{Conclusion}

Being a volunteer benefitted not only the older persons the volunteers met, but also the volunteers' own sense of meaning, by alleviating their own loneliness. Sharing existential thoughts and having meaningful conversations about life and death are challenging, but can contribute to the personal growth of the volunteers themselves. It is important to remember that not all volunteers are confident in having existential conversations, so it is important to pay attention to each volunteer's prerequisites and needs.

Keywords: encounters, existential loneliness, focus groups, individual interviews, loneliness, older people, qualitative study, volunteers 


\section{BACKGROUND}

The proportion of older people is increasing worldwide (1), challenging the healthcare sector. Another challenge is that of combating loneliness among older people. Loneliness can have severe consequences for health in terms of, for example, cardiovascular diseases and poorer mental health (2), and a study of nursing home residents found associations between emotional loneliness and mortality (3). In caring for older people, it is therefore vital to find complementary human resources, such as volunteers, to help address these challenges. The Swedish media present volunteers as a resource to reduce older people's loneliness (4). Although a large body of research explores various aspects of the involvement and role of volunteers in different contexts (e.g., 5-8), little is known of volunteers' experiences of encountering loneliness. One of the few studies of volunteers' own experiences of encountering loneliness was conducted in the palliative care context by Andersson and Öhlén (9), who concluded that there is a need for volunteer support, especially focusing on existential issues. We know that older people can experience a deep loneliness, so-called existential loneliness (10), which volunteers caring for older people certainly encounter. However, we know little about volunteers' experience of encountering older people's loneliness in general and existential loneliness in particular.

Loneliness can be measured objectively in terms of the number of friends and social contacts, but loneliness is also the subjective experience of feeling lonely. According to the results of a Swedish national longitudinal study of the long-term predictors of loneliness (11), current social engagement, current close relations, and access to social support were important factors counteracting loneliness. The importance of close and meaningful relations was also addressed in the national annual follow-up of the care of and service to older people (12), which found that the experience of loneliness was more frequently reported among residents in residential care, receiving service around the clock, than among older people living at home receiving home care. This is supported by findings of a study of loneliness among older people in residential care, showing that the experience of loneliness was not related to the number of social contacts or even to the number of contacts with family and friends; instead, emotional closeness, giving a sense of security, had an impact on loneliness (13). Feeling lonely thus does not seem to be primarily related to the accessibility of other people, but rather to the accessibility of meaningful relations. 
It is important to recall that being alone is a phenomenon with both positive and negative connotations. The literature identifies different kinds of loneliness. A conceptual review of qualitative studies of loneliness (14) identified three overlapping types, i.e., social loneliness, emotional loneliness, and existential loneliness. Social loneliness is related to both the quantity and quality of relationships and can result from the absence of social connections. Emotional loneliness is related to the absence or loss of meaningful relationships (14), and Weiss (15) described it as a subjective response to the absence of a generalized attachment figure. Existential loneliness is regarded as a human condition connected to human existence $(16,17)$ and is more associated with being separate from others and the rest of the world, especially when confronting trauma or mortality (14). According to Applebaum (18), awareness of existential loneliness emerges in moments of silence and slower-paced activity. One definition of existential loneliness, based on theoretical and empirical studies, is 'the immediate awareness of being fundamentally separated from other people and from the universe, and typically, because of this awareness, experiencing negative feelings, i.e., moods and emotions' (19). Older people themselves have described existential loneliness as being trapped in a frail body, being met with indifference, lacking meaning and purpose in life, and lacking someone to talk to about meaningful aspects of life (10). This is in line with another study of nursing homes and home care service in Sweden, showing that older people experienced a sense of alienation and insecurity and an absence of dialogue with staff (20). Also, patients with cancer and heart disease experience loneliness when they have limited opportunities to share their feelings and experiences with professionals (21). In turn, healthcare professionals find that encountering existential loneliness among older people is challenging (22), although the availability of time and opportunities differs between contexts (23). Volunteers may offer something that healthcare professionals cannot, and could be important complementary human resources, for example, contributing something from the outside world (24). As older people seem to have many unmet needs, volunteers could play an important role by providing meaningful conversations as a way to alleviate suffering and loneliness. However, there is a need for more knowledge from the perspective of the volunteers.

\footnotetext{
Aim

This study aimed to describe volunteers' experience of becoming and being a volunteer, and encountering older people's loneliness in general and existential loneliness in particular.
} 


\section{METHODS}

\section{Design}

This study is part of the LONE study (IRRID: 10.2196/13607) (25), exploring existential loneliness among frail older people from the perspective of older people themselves, their significant others, healthcare professionals, and, in this study, volunteers. The results of the LONE study, encompassing a concept analysis, qualitative studies based on various individual and focus group interviews, and quantitative studies based on questionnaires, will form the basis for developing an intervention focusing on support in encountering older people's existential loneliness. The present study had a descriptive qualitative design (26) and was based on focus group interviews as well as individual interviews with volunteers encountering older people.

\section{Participants}

A total of 32 volunteers, 23 women and 9 men aged 46-87 years, participated in the focus group interviews (Table 1). They represented different organisations, i.e., the Swedish Church, the municipal volunteer organisation, the Red Cross, and an independent organisation called the Friend-Visitor Service, from different geographical areas in southern Sweden. The selection of organisations was intended to sample different kinds of volunteer assignments and contexts, such as home visiting, volunteering in nursing homes or hospitals, and hosting at community centres. Some participants volunteered in one context only, while others operated in more than one. Depending on the context and assignment, the contacts with the older persons ranged from temporary contacts to relationships lasting several years (Table 2). The included organisations were active in larger cities, small towns, and villages. At the end of the focus group interview, the participants were asked whether they were interested in participating in an individual follow-up interview. All participants showed interest and provided contact information.

Of the participants in the focus groups, 25 were selected as eligible for participation in individual interviews, based on an intention to obtain variation in age, occupational background, and organisation. They were invited to participate by mail, e-mail, and/or telephone. Five invitees declined, seven did not reply, and one cancelled on short notice. Of the remaining twelve participants who agreed to participate, nine were women and three were men, aged 4776 years (Table 1$)$. 
Table 1. Characteristics of participants in the focus group and individual interviews

\begin{tabular}{lll}
\hline Characteristics & $\begin{array}{l}\text { Focus group interviews } \\
(n=8 \text { with 32 participants })\end{array}$ & $\begin{array}{l}\text { Individual interviews } \\
(n=12)\end{array}$ \\
\hline
\end{tabular}

\section{Participants from each volunteer organisation}

Swedish Church 13

Municipal volunteer organization

Red Cross

Friend-Visitor Service

\section{Age}

Range, years (md)

46-87 (69.5)

47-76 (69.5)

Women (\%)

$23(72 \%)$

$9(75 \%)$

Men (\%)

$9(28 \%)$

$3(25 \%)$

\section{Experience as a volunteer ${ }^{1}$}

1-2 years

3-4 years

6

5-6 years 7

7-8 years 2

9-10 years

$>10$ years

\section{Occupational background ${ }^{1}$}

Health and social care

Education

Pharmacist/audiologist

Lawyer/banker

Craftsperson

Self-employed

Salesperson

Other/not specified

$1 / 3$

\footnotetext{
${ }^{1}$ Missing data from the two pilot focus groups (eight participants)
} 
Table 2. Organisational affiliation and context of the volunteers participating in the individual interviews

\begin{tabular}{ll}
\hline Organisation & Context \\
\hline $\begin{array}{l}\text { Municipal volunteer } \\
\text { organisation }\end{array}$ & $\begin{array}{l}\text { Home visiting, visiting a nursing home, and } \\
\text { hosting at the community centre }\end{array}$ \\
The Swedish Church & $\begin{array}{l}\text { Hosting in the Church, home visiting, and } \\
\text { visiting a nursing home }\end{array}$ \\
$\begin{array}{l}\text { The Swedish Church at the } \\
\text { hospital }\end{array}$ & $\begin{array}{l}\text { Hosting at the hospital emergency department } \\
\text { in the waiting room }\end{array}$ \\
The Red Cross & $\begin{array}{l}\text { Home visiting and visiting a nursing home } \\
\text { Friend-Visitor Service }\end{array}$ \\
& $\begin{array}{l}\text { Hosting at the community centre and home } \\
\text { visiting }\end{array}$ \\
\hline
\end{tabular}

\section{Data collection and procedure}

Data were gathered from focus group and individual interviews. This combination was used based on the idea that participants in focus group interviews develop their ideas when they share and discuss their experiences with others (27), while individual interviews can contribute to an in-depth understanding of a given phenomenon (28). The main interest in the focus group interviews was the volunteers' experience of encountering older people's loneliness in general and existential loneliness in particular. However, as the focus group discussions concentrated on encountering loneliness in general, the data collection was supplemented with individual interviews to obtain more in-depth data about encountering existential loneliness and about personal motives for becoming a volunteer. The data from the first six focus group interviews have also been analysed to explore volunteers' perceptions of older people's existential loneliness and are presented elsewhere in Swedish (29).

\section{Focus group interviews}

The data collection started with two focus group interviews in 2014, serving as pilot interviews. As only minor revisions needed to be made to the pilot interview guide, these interviews were included in the main study. Another six focus group interviews were performed during 2017 
and 2018, for a total of eight focus group interviews. The practical arrangements were coordinated by a contact person in each local volunteer organisation who also distributed written information about the study to all members. Those interested in participation contacted the contact person, who in turn informed the researchers.

Each focus group interview was scheduled to last two hours and was conducted in a room designated by the organisation. The focus group interviews were performed in different configurations by a team of four, with the first (MS) and the second (KB) authors leading six of the eight sessions, as either moderator or facilitator. The moderator led the discussion, while the role of the facilitator was to be attentive to issues that otherwise might be overlooked, take notes, and summarise the discussions at the end of the focus group. All focus group interviews followed the same structure. The moderator started each session by informing the participants of the study's purpose and then obtaining written consent. All interviews were introduced in the same way, with the participants being asked to reflect on loneliness in general and existential loneliness in particular among older people. Thereafter questions were asked about their experiences of being volunteers, encountering older people's loneliness and existential loneliness. The moderator asked follow-up questions such as 'Has anyone else had similar experiences?' or 'Do I understand you correctly when you say ...?' Before ending each interview, the participants were asked if there was anything they wanted to add.

Seven focus groups had three to four participants, while one focus group had seven participants.

Demographic information such as age, volunteer experience, and current or previous profession was collected after the interview, apart from the pilot interviews where no such information was collected. One interview lasted 69 minutes and the others 91-111 minutes; the interviews were audio-recorded and transcribed verbatim.

\section{Individual interviews}

The individual interviews were conducted between October and December 2018. A pilot individual interview was first performed; as only minor revisions needed to be made to the interview guide used, this interview was included in the main study. The date and place of the interview were chosen by each participant, i.e., a place connected to the organisation, the interviewee's home, or the university. All interviews were performed by the first author (MS), who, before each interview began, presented the purpose of the study, repeated the written information everyone had received in advance, and obtained the participant's written consent. 
The interview guide was semi-structured (30) and included most of the same questions as used in the focus groups, i.e., asking about the volunteers' experience of encountering older people's loneliness, but with a more specific emphasis on encountering existential loneliness. The individual interviews focused more on the volunteers' individual experiences, such as motives for becoming a volunteer. The interviewer asked follow-up questions such as 'What do you mean by that?' and 'Do I understand you correctly when you say ...?' Before ending each interview, the participant was asked if there was anything $\mathrm{s} /$ he wanted to add. The interviewer finally informed the participant about what had been noted during the interview; the interviewee was asked to confirm these results, and was encouraged to further develop his/her thoughts. This part of the interview also served as a quick member check. The interviews lasted 45-97 minutes ( $\mathrm{md}=72$ minutes), were audio-recorded, and transcribed verbatim.

\section{Analysis}

Conventional content analysis (31) was used to analyse the data. First, all authors read all interview transcripts to achieve immersion and obtain a sense of the whole. The first and third authors then discussed their impressions and how to proceed. Since the individual interviews were characterised by more in-depth data, the authors started by analysing them. Meaning units related to the aim were identified and coded by the first author and a coding scheme was created. Next, the focus group interviews were read and coded in the same way. When all data were coded, all three authors discussed the coding, and grouped the codes into 13 meaningful clusters (31) (Appendix). During the analysis, there was constant movement between the parts and the whole, i.e., between the texts, codes, clusters, and tentative categories. The final structure comprised four categories. According to Hsieh and Shannon (31), researchers might also decide to identify relationships between categories. In our analysis, one overall understanding of becoming and being a volunteer, encountering older people's loneliness in general and existential loneliness in particular, was constructed.

\section{Ethical considerations}

According to the principles of autonomy, nonmaleficence, and beneficence (32), the following aspects were considered. All prospective participants were given advance opportunity to consider participation by receiving written information on the study; those who agreed to participate gave their written consent. In some cases, considerable time had passed between the focus group and the individual interviews, so special attention was paid to participant doubtfulness, even though participants had earlier expressed interest in participating. To make 
the participants feel as comfortable as possible, they chose the place for the individual interviews. As existential loneliness is a sensitive topic, the interviewers tried to be attentive for any signs of discomfort during the interviews.

\section{FINDINGS}

The overall understanding of becoming and being a volunteer encountering older people's loneliness in general and existential loneliness in particular was Being a fellow human beingalleviating loneliness for others and oneself. The volunteers had a specific mission in the care of older people and emphasised that their role differed from that of the healthcare professionals, in that their role was simply to be fellow human beings. As a volunteer, one usually had more time than the healthcare professionals, who often had someone else waiting for attention. The volunteers said that trusting relations were built over time and that reciprocity was essential, i.e., meeting as two equal human beings. Volunteering and having close and meaningful relationships with the visited older persons were experienced as alleviating both the older persons' and the volunteer's own loneliness. The volunteers also alleviated their loneliness through the opportunity for social activities with other volunteers. The volunteers could relate to their own experiences, which in turn affected their view of loneliness and existential loneliness and how these were experienced and approached.

Becoming and being a volunteer encountering older people's loneliness and existential loneliness encompassed four categories: one category embracing the experience of becoming a volunteer as 'A way to find meaning', two categories embracing the experience of being a volunteer as 'Feeling rewarded as well as emotionally challenged' and 'Acting in line with one's values, thereby challenging boundaries', and finally one category embracing the experience of encountering loneliness in general, and existential loneliness in particular, as 'Being sensitive to others' needs for closeness and distance' (Figure 1). 
Being a fellow human being: alleviating loneliness for others and oneself

\begin{tabular}{|c|}
\hline $\begin{array}{c}\text { Becoming a volunteer } \\
\text { A way to find meaning }\end{array}$ \\
\hline Being a volunteer \\
Feeling rewarded as well as emotionally challenged \\
Acting in line with one's values, thereby challenging boundaries \\
\hline Encountering older peoples' loneliness in general and existential \\
loneliness in particular \\
Being sensitive to others' needs for closeness and distance
\end{tabular}

Figure 1. Becoming and being a volunteer encountering older people's loneliness and existential loneliness.

\section{Becoming a volunteer}

A way to find meaning

The decision to become a volunteer was based on various motives and driving forces. One motive was to do good for someone else in general and to older people in particular. A second motive was to do something meaningful. A third motive was to give something back to society, linked to the idea of one's duty as a citizen. To be appreciated, affirmed, and needed by another person were other motives mentioned by the volunteers. Several participants started to volunteer shortly after retirement, based mainly on insight into their new situation and a desire to do something with their time to counteract boredom.

Well, I've actually never had a problem with loneliness, more than when my parents passed away. I did feel emptiness then. And, in fact, I had to fill that ... that emptiness ... with human contact. I was in the habit of visiting them once a day, so I had to fill that gap with something. (Focus group interview 7)

Moreover, some of them mentioned a feeling of still having something to offer others, but not necessarily involving close, long-term relationships. Other volunteers mentioned that their parents, no longer alive, had felt trapped and abandoned when they were nursing home 
residents, so they volunteered as a way to continue to do good, to restore themselves, or even as part of mourning.

\section{Being a volunteer}

Feeling rewarded as well as emotionally challenged

Being a volunteer was considered an honourable and rewarding mission. The mission was described as enriching, meaningful, and bringing pleasure, making the volunteers feel valuable. The volunteers considered the ability to create trusting relations and to receive and maintain the older person's trust to be highly important. They also emphasised that the relationship was reciprocal and rewarding for themselves on a personal level. The relationship differed from other relationships, even for those who had previously worked in the healthcare sector.

I mean you're just two individuals, of different generations or whatever, right? It's of course not a matter of ... if you're staff, you kind of have your professional role - that you have to maintain a professional manner. And that ... of course for a volunteer it's not like that at all. (Individual interview 5)

Being a volunteer could also mean 'feeling like an outsider' in the care context. Some participants described their frustration at not being included in the setting where they volunteered, being taken for granted by the healthcare professionals in the setting, feeling used, or being viewed as an inconvenience, all of which complicated their mission. However, some participants also described the opposite, i.e., a sense of belonging and being included in the setting or organisation. Depending on the setting, there was freedom as to when and how the voluntary assignment should be performed and to operate in accordance with one's values. Others described the mission as being a cog in a wheel and as something valuable.

The volunteers described their mission as one that taught them life lessons, but also as an existential and emotional challenge. There were feelings of frustration, powerlessness, and helplessness, and a feeling of inadequacy: 'But then again, sure, there are times when you feel inadequate and would like to be able to somehow break through even more, you know?' (Focus group interview 8). When encounters or situations were difficult to handle or distressing, most volunteers had someone in the organisation to whom they could turn when needed. Others 
described taking a moment to be by themselves as helpful, or to talk with a close family member. The boundary between volunteering and friendship became increasingly blurred the longer the assignment lasted: the older person had become a friend, and at the same time was not one. This relationship affected the volunteers personally, and they highlighted their own need for continuity and the importance of ending a relationship in a positive way.

Acting in line with one's values, thereby challenging boundaries

Being a volunteer meant having a frame for a mission, a space in which to act in line with one's values. Some volunteers emphasised the importance of understanding the limitations of their mission, while others instead expressed uncertainty. As a volunteer, making home visits meant more freedom, while volunteering at the hospital meant adjusting to predetermined routines and boundaries. The mission included encountering the older person as a unique person, so, when necessary, some volunteers challenged boundaries, not being held back by routines.

So, I did some things that a volunteer maybe shouldn't do.

Interviewer: What did you do?

I became ... well, I became quite close to her. I accompanied her on visits to the physician and helped her move to another place. These are things that a volunteer is not supposed to do.

Interviewer: So you did quite lot of practical things as well?

Yes, there was quite a lot of practical work. In between, we sat and talked, and she cried and told me about her life. (Individual interview 3)

Being a volunteer meant being able to adjust to these boundaries and what was possible to do, being able to let go, and feeling that one had done enough. The mission could include encounters with healthcare professionals and with relatives who did not act in accordance with the volunteers' own values, which was frustrating. Acting in line with one's values could also involve acting as a representative when an older person could no longer fully manage on his/her own, sometimes challenging set boundaries, for example, in situations when the older person has no one else to rely on and the volunteer has become the only source of personal support. 
Furthermore, this entailed keeping up to date about activities that the older person enjoys but can no longer do by him/herself. Being a representative of the older person was not a formal or explicit role, but an informal role as a fellow human being.

\section{Encountering older people's loneliness in general and existential loneliness in particular}

Being sensitive to others' needs for closeness and distance

According to the volunteers, some older persons were not ready or lacked the ability to talk about existential loneliness or have existential conversations. Therefore, the volunteer's own ability to be sensitive to the other's needs was essential. Some volunteers described the importance of closeness and of alternation between closeness and distance, while others considered distance to be necessary. Visiting an older person, who seemed to live a slow and monotonous life from the outside, meant adjusting to the situation, mostly talking, and just 'being' together. One participant called the visit 'a brief glimpse into existence', aware that the visit lasted only a moment. According to the volunteers, expressing one's existential needs and suffering may be difficult for some older persons, and lack of appropriate words could be one reason for this. The volunteers said that they encountered older people who did not want to be a burden or did not have anyone to confide in, which led them to keep concerns to themselves. The importance of being respectful, being attentive, and listening to the older person's needs was emphasized. Words were not always the most important tool, and being comfortable with silence and adjusting to a slower pace were described as undervalued abilities one needs to learn as a volunteer.
What happens happens, you know, so that thoughts can ripen or end up somewhere and then ... then, like I said, you can of course spend time together and have a sense of togetherness without necessarily talking. And you need a bit of training - to learn how not to feel some sort of panic if there's only silence, you know, how to simply let the silence be. (Individual interview 1)

The volunteers described kindness and consideration, as well as being able to listen without interrupting or judging, as essential for having meaningful conversations. Existential conversations concerning death, guilt, or shame were not planned, but emerged spontaneously. The volunteers emphasised how important it was to alternate between depth and surface, 
depending on the needs of the older person. The volunteers stressed that although they were prepared to have existential conversations, the older person also needed to be ready: it was important to be sensitive and to show respect if someone did not want to deepen the conversation.

At the same time, listening to the older person's existential concerns presupposed selfawareness and having processed one's own beliefs. Some volunteers tried to deflect conversations about loneliness, not giving it too much attention, which could lead to superficial conversations; instead, they would encourage more positive conversations, and strive to bring joy and laughter into the older person's lonely existence.

\begin{abstract}
No, but it is that way, usually that's maybe what you start talking about - not death, but about this feeling of loneliness ... I mean, it starts with the old lady saying, like, 'Oh, I'm so happy you came! I've missed you so much! I've been so lonely,' she'll say. And so that's like an opening. And then you get chatting and then I might try to ... I mean, at the same time I think you shouldn't try to expand on this feeling, make it stronger. (Focus group interview 1)
\end{abstract}

The volunteers described existential loneliness as related to the older person's present as well as past life, including thoughts such as 'What have I done?' and 'What has life given me?' It was a feeling that could not be fully shared with anyone else, but was something that must be partly dealt with on one's own. Participants stated that existential concerns were to be met with respect and authenticity, although some volunteers avoided existential conversations as they thought others were better equipped for them. Although the volunteers mostly discussed simply 'being' with the older person, 'doing' things was also described as important. This could mean taking an active part in planning future activities and meaningful events with the older person, which could include space for existential and meaningful conversations. 


\section{DISCUSSION}

The overall understanding of becoming and being a volunteer encountering older people's loneliness in general, and existential loneliness in particular, was being a fellow human being - alleviating loneliness for others and oneself. Being a volunteer in the care of older people was beneficial not only for the older persons, but also for the volunteers' own sense of meaning and community. Our findings indicated various motives for volunteering, such as doing good, being needed by somebody, being appreciated, and being affirmed. Thus, one driving force of being a volunteer was to find meaning. Viktor Frankl claimed that searching for meaning is a primary force in life (33), and further described a lack of meaning as an existential vacuum, i.e., boredom and meaninglessness in life. Volunteering might therefore be one means to counteract one's own existential vacuum. Being a volunteer also taught life lessons, and the relationship with the older person could gradually become more of a friendship than a formal volunteer-'client' relationship. This unique relationship and the specific role of the volunteer have been highlighted in other studies. Volunteers caring for an older person, but not belonging to that person's social circle, offer existential encounters not otherwise available (34), while the presence of volunteers in a palliative care context gives patients an opportunity to talk freely, without having to worry family or friends (35). Sharing existential thoughts about life and anticipated death could even be rewarding for the volunteer and a way of being introduced to existential issues (34). Planalp, Trost, and Berry (36) showed that having meaningful conversations about existential matters, such as the meaning of life, was a challenge for volunteers, but also rewarding in terms of life lessons. This is in line with the present finding that being a volunteer meant being emotionally challenged, but also feeling rewarded. Furthermore, being a volunteer in the care of older people with dementia has been described as a mission that leads to increased learning and self-reflection (37). Sharing existential thoughts and having meaningful conversations about life and death is challenging, but it can contribute to personal growth for the volunteers themselves.

The participants' own life experiences affected their views of loneliness and existential loneliness and seemed to contribute to sensitivity to others' needs for both closeness and distance. A study from Norway in a municipal palliative care context highlighted volunteers' life experience and relational skills, i.e., being able to talk about disease and death, as advantages (38). A relationship based on reciprocity requires what Schuster (39) calls the presence of personal existential space. According to Schuster (39), personal existential space 
differs from professional/external space in that the personal space is inherent to our bodies and existence. By affirming one's personal existential space, equal relationships can develop. However, there are situations in which communication difficulties and lack of words to express existential needs can threaten conversations about existential issues. Being sensitive to the older person's vulnerability, using one's imagination and empathy, could be the key to getting closer to the older person (22). Also, providing volunteers with a space in which to act, where their own life experiences are acknowledged as a strength, and making volunteers part of the team seem essential (40). Söderhamn et al. (38) further stressed the importance of volunteers having a clear and defined role, not only for themselves but also for healthcare staff. It was crucial to have access to a mentor and to follow up after a volunteer session, especially at the start of the volunteer engagement. Even so, our results indicate that not all volunteers were confident in having existential conversations, and some avoided them. Perhaps one of the most important things is to have knowledge of each volunteer's prerequisites and needs and to adjust the assignment accordingly. Improvement is needed in several areas concerning support for volunteers in their engagement. Knowledge of this can enable policymakers, non-governmental organisations (NGOs), and leaders in the health and social care of older people to further develop volunteer service in the best interest of volunteers and the older people they visit.

\section{Methodological considerations}

Focus groups and individual interviews are used for different purposes. Focus groups are used to capture various perceptions and experiences (27). Existential loneliness is not a topic usually discussed on a daily basis, so focus groups were used to facilitate the sharing of experience and support reflection on existential loneliness. The individual interviews, on the other hand, enabled the generation of more in-depth data and created a space in which to develop reasoning, experience, and beliefs (28). Regarding the number of participants in focus group interviews, Krueger and Casey (27) recommended five to eight participants as the ideal size, though if the topic is complex, fewer participants are recommended. Since loneliness in general and existential loneliness in particular are sensitive and complex topics, smaller groups of three or four participants seemed relevant (27). In this study, the larger groups tended to hold discussions on a general level, while the smaller groups facilitated interaction and the sharing of individual experiences. 
The individual interviews ended with a member check. This was an opportunity for the participants to clarify their intentions, confirm what had been said, and, if necessary, to refine their reasoning. The member check can be seen as strengthening the credibility of the present findings (41). To increase the trustworthiness of our findings, quotations from both focus groups and individual interviews have been cited to illustrate that the findings emerged from both types of data (41). Qualitative researchers influence both the collection and interpretation of data, and the understandings and meanings of data are negotiated in a given social context (42). Reflection was therefore vital throughout the research process, and was conducted in regular reflective discussions between the authors. Furthermore, the results were presented and discussed in a reference group connected to the LONE study, in which some of the participants were experienced volunteers. Concerning the transferability of the results, it is important to recall that the study was performed in a Scandinavian context, as traditions of volunteers in the care of older people vary between countries.

\section{CONCLUSION AND CLINICAL IMPLICATIONS}

Being a volunteer was beneficial not only for the older persons the participants encountered, but also for the volunteers' own sense of meaning, alleviating their own loneliness. Sharing existential thoughts and having meaningful conversations about life and death are challenging, but can contribute to the personal growth of the volunteers themselves. It is important to bear in mind that not all volunteers are confident in having existential conversations; it is important to pay attention to each volunteer's prerequisites and needs, and several areas of support for volunteers' engagement need improvement. Knowledge of these matters can enable policymakers, NGOs, and leaders in the health and social care of older people to further develop volunteer service in the best interests of the volunteers and the older people they visit, as an essential complement to more formal healthcare services.

\section{AUTHOR CONTRIBUTION}

MS, KB, and AKE designed the study. MS and KB collected the data, while MS, AKE, and KB analysed them. MS was responsible for drafting the manuscript, but all authors contributed substantially to the writing. 


\section{ETHICAL APPROVAL}

This study was approved by the Ethical Review Board, Lund (ref. 2014/652 and 2018/715), as part of the LONE study.

\section{FUNDING}

This study was supported by the Research Platform for Collaboration for Health at Kristianstad University, and the Vårdal Foundation.

\section{ACKNOWLEDGEMENTS}

We are grateful to all the volunteers for generously sharing their experiences, to Charlotte Olsson and Carina Rydsten for contributing to the data collection, to the contact persons in the volunteer organisations for their assistance, and to the LONE research group and the reference group for their valuable input. This study was conducted in association with the Swedish National Graduate School for Competitive Science on Ageing and Health (SWEAH), funded by the Swedish Research Council. 


\section{REFERENCES}

1. World Health Organization (WHO). World Report on Ageing and Health. 2015, WHO Press, Geneva.

2. Leigh-Hunt N, Bagguley D, Bash K, Turner V, Turnbull S, Valtorta N, et al. An overview of systematic reviews on the public health consequences of social isolation and loneliness. Public Health 2017; 152:157-71.

3. Drageset J, Eide GE, Kirkevold M, Ranhoff AH. Emotional loneliness is associated with mortality among mentally intact nursing home residents with and without cancer: a fiveyear follow-up study. J Clin Nurs 2013; 22(1-2):106-14.

4. Ågren A. What are we talking about? Constructions of loneliness among older people in the Swedish news-press. J Aging Stud 2017; 41:18-27.

5. Principi A, Galenkamp-van der Ploeg H, Papa R, Socci M, Suanet B, Schmidt A, et al. Do predictors of volunteering in older age differ by health status? Eur J Ageing 2016; 13(2):91-102.

6. Chen L-K. Benefits and dynamics of learning gained through volunteering: A qualitative exploration guided by seniors' self-defined successful aging. Educ Gerontolog 2016; 42(3):220-30.

7. Sellon AM, Chapin RK, Leedahl SN. Engaging Nursing Home Residents in Formal Volunteer Activities: a Focus on Strengths. Ageing Int 2017; 42(1):93-114.

8. Connell B, Warner G, Weeks LE. The Feasibility of Creating Partnerships Between Palliative Care Volunteers and Healthcare Providers to Support Rural Frail Older Adults and Their Families: An Integrative Review. Am J Hosp Palliat Med 2017; 34(8):786-94.

9. Andersson B, Öhlén J. Being a hospice volunteer. Palliat Med 2005; 19(8):602-9.

10. Sjöberg M, Beck I, Rasmussen BH, Edberg AK. Being disconnected from life: meanings of existential loneliness as narrated by frail older people. Aging Ment Health 2018; 22(10): 1357-64.

11. Dahlberg L, Andersson L, Lennartsson C. Long-term predictors of loneliness in old age: results of a 20-year national study. Aging Ment Health 2018; 22(2):190-6.

12. National Board of Health and Welfare. Older people's view about care and service [In Swedish: Så tycker de äldre om äldreomsorgen]. 2016, Socialstyrelsen, www.socialstyrelsen.se 
13. Drageset J, Kirkevold M, Espehaug B. Loneliness and social support among nursing home residents without cognitive impairment: a questionnaire survey. Int J Nurs Stud 2011; 48(5):611-9.

14. Mansfield L, Daykin N, Meads C, Tomlinson A, Gray K, Lane J, et al. A conceptual review of loneliness across the adult life course (16+ years). 2019, What Works Centre for Wellbeing, London.

15. Weiss RS. Loneliness: the Experience of Emotional and Social Isolation. 1973, The MIT Press, Cambridge.

16. Yalom I. Existential Psychotherapy. 1980, Basic Books, New York.

17. Tillich P. The Eternal Now. 1963, SCM Press, London.

18. Applebaum F. Loneliness: A taxonomy and psychodynamic view. Clin Soc Work J 1978; 6(1):13-20.

19. Bolmsjö I, Tengland PA, Rämgård M. Existential loneliness: An attempt at an analysis of the concept and the phenomenon. Nurs Ethics 2019; 26(5):1310-25.

20. Svanström R, Johansson Sundler A, Berglund M, Westin L. Suffering caused by careelderly patients' experiences in community care. Int J Qual Stud Health Well-being 2013; $8(1)$.

21. Karhe L, Kaunonen M. Patients' Experiences of Loneliness in a Professional Caring Relationship. Int J Hum Caring 2015; 19(1):19-26.

22. Sundström M, Edberg AK, Rämgård M, Blomqvist K. Encountering existential loneliness among older people: perspectives of health care professionals. Int J Qual Stud Health Well-being 2018; 13(1).

23. Sundström M, Blomqvist K, Edberg AK, Rämgård M. The context of care matters: Older people's existential loneliness from the perspective of healthcare professionals. A multiple case study. Int J Older People Nurs 2019; 14(3).

24. Morris SM, Payne S, Ockenden N, Hill M. Hospice volunteers: bridging the gap to the community? Health \& Social Care in the Community 2017; 25(6):1704-13.

25. Blinded for review.

26. Polit DF, Beck CT. Nursing Research: Generating and Assessing Evidence for Nursing Practice. (9th ed.) 2012, PA: Wolters Kluwer/Lippincott, Philadelphia.

27. Krueger RA, Casey MA. Focus Groups: A Practical Guide for Applied Research. (5th ed) 2015, Sage, Thousand Oaks.

28. Ryan F, Coughlan M, Cronin P. Interviewing in qualitative research: The one-to-one interview. Int $J$ Ther Rehabil 2009; 16(6):309-14. 
29. Blinded for review.

30. Brinkmann S, Kvale S. InterViews: Learning the Craft of Qualitative Research Interviewing. 2015, Sage Publications, Los Angeles.

31. Hsieh HF, Shannon SE. Three approaches to qualitative content analysis. Qual Health Res 2005; 15(9):1277-88.

32. Beauchamp TL, Childress JF. Principles of Biomedical Ethics. (7th ed.) 2013, Oxford University Press, New York.

33. Frankl V. Man's Search for Meaning [In Swedish: Livet måste ha mening]. 2006, Natur och kultur, Stockholm.

34. Stephens J, Simpson T, Holmes OS, Collins R, Silver M, Bhar SS. Volunteers Befriending Older Adults in Aged Care Residencies: Three Case Studies: Befriending in aged care residencies. Australian Psychologist 2016; 51(2):164-70.

35. Dodd S, Hill M, Ockenden N, Algorta GP, Payne S, Preston N, et al. 'Being with' or 'doing for'? How the role of an end-of-life volunteer befriender can impact patient wellbeing: interviews from a multiple qualitative case study (ELSA). Support Care Cancer 2018; 26(9):3163-72.

36. Planalp S, Trost MR, Berry PH. Spiritual Feasts: Meaningful Conversations between Hospice Volunteers and Patients. Am J Hosp Palliat Med 2011; 28(7):483-6.

37. Greenwood DE, Gordon C, Pavlou C, Bolton JV. Paradoxical and powerful: Volunteers' experiences of befriending people with dementia. Dementia 2018; 17(7):821-39.

38. Söderhamn U, Flateland S, Fensli M, Skaar R. To be a trained and supported volunteer in palliative care - a phenomenological study. BMC Palliat Care 2017; 16(1):18.

39. Schuster M. Profession and Existence: a Hermeneutic Study of Assymmetri and Reciprocity in Nurses'Encounters with Servere Ill Patients. [In Swedish: Profession och existens: en hermeneutisk studie av asymmetri och ömsesidighet i sjuksköterskors möten med svårt sjuka patienter]. 2006, Daidalos AB, Gothenburg.

40. Leyshon C, Leyshon M, Jeffries J. The complex spaces of co-production, volunteering, ageing and care. Area 2019; 51(3):433-42.

41. Guba EG. Criteria for assessing the trustworthiness of naturalistic inquiry. Educational Communication and Technology 1981; 29(2):75-91.

42. Finlay L. Negotiating the swamp: the opportunity and challenge of reflexivity in research practice. Qualitative Research 2002; 2(2):209-30. 
APPENDIX. Clusters of codes

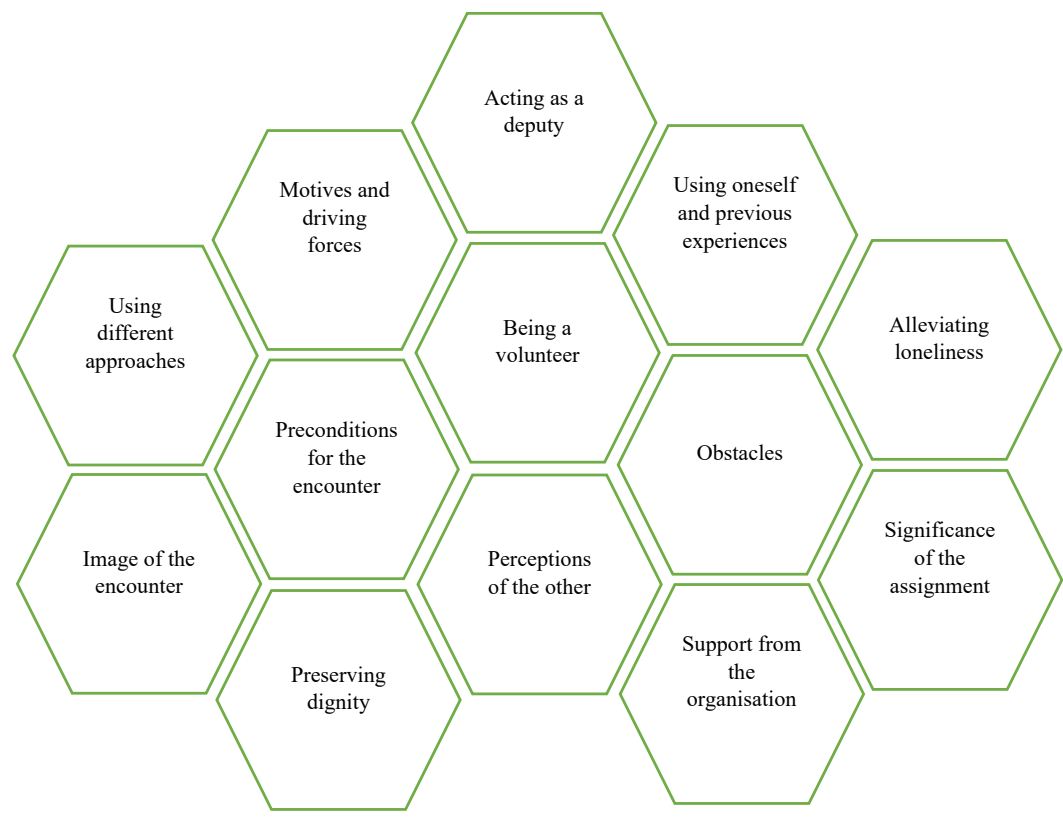



IV 



\section{Manuskript}

Encountering older persons' existential issues: First-line managers' views of staffs' and volunteers' possibilities, obstacles and need for support

Malin Sundström, RN, MSc, ${ }^{1,2}$ Kerstin Blomqvist, RNt, PhD, ${ }^{1}$ Margareta Rämgård, RN, $\mathrm{PhD},{ }^{2}$ Anna-Karin Edberg, $\mathrm{RN}, \mathrm{PhD}^{1}$

${ }^{1}$ Research Platform for Collaboration for Health, Faculty of Health Science, Kristianstad University, Kristianstad, Sweden

${ }^{2}$ Faculty of Health and Society, Malmö University, Malmö, Sweden

\section{Corresponding author}

Malin Sundström

Kristianstad University

SE-291 88 Kristianstad

+46442503879

malin.sundstrom@hkr.se 


\begin{abstract}
Background

Regardless of one's age, having existential needs and thoughts is part of being human. Homeand residential-care staff find it challenging to make time for conversations about existential considerations, but if existential needs are not met or addressed, a feeling of existential loneliness may arise among the cared-for older persons. Beyond staff, volunteers are a group whose expertise could help satisfy older persons' existential needs.
\end{abstract}

\begin{abstract}
Aim
The aim was, from the perspective of first-line managers, to investigate staffs' and volunteers' possibilities and obstacles as well as need for support, in encountering older persons' existential issues.
\end{abstract}

\title{
Methods
}

In a cross-sectional design, first-line managers in home- and residential care were randomly selected. A self-administered questionnaire with closed- and open-ended questions was distributed online, and 136 managers participated.

\section{Results}

First-line managers reported that older persons frequently (11\%) or sometimes $(77 \%)$ expressed existential loneliness and that staff frequently $(13 \%)$ or sometimes $(68 \%)$ had conversations about existential issues. These conversations concerned the present life situation, the past and uncertainty about the future, and death and dying. The major obstacle to such existential conversations was insecurity, experienced by $88 \%$ of staff. Support to staff was mostly provided by managers or registered nurses, but structured reflection $(36 \%)$ and clinical supervision (6\%) also occurred. Nearly half of the managers had volunteers in their units, their most common activity being everyday conversations, followed by music/ entertainment and walking/outdoor activity.

\section{Conclusion}

Older persons' existential needs merit attention, particularly in home and residential care. Staff's insecurity about encountering existential needs and existential conversations must be addressed and appropriate support provided on a regular basis as an integral part of work.. In times of limited resources, new solutions are needed. Volunteers are a human resource that could improve the well-being of older persons and complement staff work. 


\section{BACKGROUND}

Regardless of one's age, having existential needs and thoughts is part of being human, but if existential needs are not met or addressed, a feeling of being alone in the world, of existential loneliness, may arise (Sand \& Strang, 2006). Home- and residential-care staff should be prepared to address existential as well as other needs. Research shows that it is challenging for staff to find time in their daily work for conversations about existential considerations (Beck, Törnquist, Broström, \& Edberg, 2012; Norell Pejner, Ziegert, \& Kihlgren, 2012). Insecurity and fear are other challenges facing such staff when it comes to addressing existential issues (Sundström, Edberg, Rämgård, \& Blomqvist, 2018). Despite these challenges, the needs of older persons should be met by care staff. Beyond care staff, volunteers are a group whose expertise can be used in satisfying older persons' existential needs (Sundström, Blomqvist, \& Edberg, submitted). It is the first-line manager's responsibility to ensure that all the needs - physical, psychological, social, as well as existential - of older persons are met.

Older people are not a homogenous group, in either society or the care context. People age differently, so becoming old is a complex process and a unique experience for each person. Becoming old can be seen as an ontological challenge (Shaw, West, Hagger, \& Holland, 2016) as horizons shrink over time due to growing incapacities. The older person's frail and unpredictable body can evoke a feeling of being imprisoned and trapped (Ebrahimi, Wilhelmson, Eklund, Moore, \& Jakobsson, 2013; Sjöberg, Beck, Rasmussen, \& Edberg, 2018). Besides losses and declining health (Baltes \& Smith, 2003), there are other aspects of becoming old, such as turning inwards and reflecting on how life unfolded (Andersson, Hallberg, \& Edberg, 2008; Santamäki Fischer, Norberg, \& Lundman, 2008). Affirming both the positive and challenging aspects of life and death can be important. Furthermore, the meaning of being old can encompass contradictions and paradoxes, such as how to embrace both weakness and strength, reconciliation and regret (Santamäki Fischer et al., 2008). Yet being dependent on others, for example, needing care and lacking control, can lead to vulnerability (Abley, Bond, \& Robinson, 2011), while not being recognized or being met with indifference can cause suffering, alienation, and existential loneliness (Sjöberg et al., 2018; Svanström, Johansson Sundler, Berglund, \& Westin, 2013). Feelings of abandonment and anxiety about one's future can cause inner pain and emotional suffering, but this experience can be manageable if accepted and acknowledged by others (Sjöberg, Edberg, Rasmussen, \& 
Beck, 2019; Wijesiri et al., 2019). Acknowledging the older person and recognizing his or her existential needs and thoughts about life and the meaning of the past, the present, and approaching death are therefore crucial parts of caring.

Apart from insecurity and fear, the care setting, as a place and context, can hinder staff from recognizing existential needs. To illustrate this, Wolf, Ekman, and Dellenborg (2012) conducted an ethnographic study, finding that sound, light, and the pace and focus of care in a medical ward challenged and impeded staff in focusing on and adjusting to older persons' needs, evoking feelings of guilt. The care context matters for healthcare professionals' prerequisites for addressing existential issues and needs in home, residential, hospital, and palliative care, according to a multiple case study by Sundström, Blomqvist, Edberg, and Rämgård (2019). Time constraints were seen as hindering, as were professionals' discomfort in discussing existential concerns and inability to address older persons' existential needs. The exception was in palliative care where existential conversations were considered part of the work and, unlike in other care contexts, staff had regular access to clinical supervision and meetings for reflection. However, according to an observational study of a UK hospice ward (Hill, Evans, \& Forbat, 2015), nurses had different ways of responding to patients' psychosocial needs. Barely half of the nurses responded to the needs, a third of the nurses ignored them, and the rest either deferred or diverted the needs. Nursing assistants providing end-of-life care in a nursing home were found to concentrate on bodily care rather than the older persons' existential needs (Holmberg, Hellström, \& Österlind, 2018). In addition, a study of communicative challenges in home care found that older persons' existential issues, worries, and even fragility were often vaguely expressed and therefore difficult for nursing assistants to grasp (Sundler, Eide, van Dulmen, \& Holmström, 2016). Altogether, this indicates a need for support to help staff address older persons' existential needs. First-line managers' views of staff support accordingly merit further investigation because they shape the reality in which municipal first-line managers operate and exert influence.

Besides staff, volunteers are another possible resource in the care of older people. A multiple case study from the UK (Dodd et al., 2018) examined the role of volunteers in end-of-life care in different settings. The results indicated that the combination of not being too close to or in a dependency relationship with the care recipient as well as relationship 'chemistry' enabled more open and freer conversations about problems and one's life story without fear of worrying family and friends. Regularly having such conversations was seen by patients as a 
way to put their lives in context. However, an earlier Swedish study by Andersson and Öhlén (2005) revealed a need to support volunteers regarding existential issues. Moreover, an integrative review of palliative care volunteers showed that training was central to volunteers' success (Connell, Warner, \& Weeks, 2017). A recent study of being a volunteer encountering older people's existential loneliness showed that volunteers' own experiences affected their approach to existential loneliness and existential conversations (Sundström et al., submitted), meaning that volunteers can be more or less prepared for existential conversations with older persons.

Since an important part of the first-line manager's role is to meet the needs of older persons and support their employees, the manager's role is crucial. The focus of this study is accordingly on first-line managers in home- and residential care and their views of how the existential needs of older persons are met, and on the support needs of staff and volunteers.

\begin{abstract}
Aim
The aim of this study was, from the perspective of first-line managers, to investigate staffs' and volunteers' possibilities and obstacles as well as need for support, in encountering older persons' existential issues.
\end{abstract}

\title{
METHODS
}

\section{Design}

This study had a cross-sectional design with a sample of randomly selected first-line managers working in Swedish municipal care and service. The study was based on a questionnaire distributed online. A structured questionnaire, specifically designed for this study, was used to collect information at the national level. The study is part of the LONE study (IRRID: 10.2196/13607) (Edberg \& Bolmsjö, 2019) whose aim is to explore existential loneliness from the perspective of frail older people, their significant others, and health-care professionals. In the LONE study, frail older people are defined as persons aged $\geq 75$ years who are receiving long-term care from formal caregivers employed by the municipality or the county council. 


\section{Context}

In Sweden, life expectancy is 84.1 years for women and 80.7 years for men and persons $\geq 80$ years old constitute about $5 \%$ of the population (National Board of Health and Welfare, 2019). In Sweden, municipal care for older people is primarily tax financed, and older people can apply for various kinds of support. Municipal care and services for the older people is mainly regulated by the Health and Medical Service Act (2017:30) and Social and Service Act (2001:453). This care can be provided by public or private actors or foundations but is still a municipal responsibility. There is a stated principle of letting the older person live at home for as long as possible, i.e., ageing in place. Since more complex care is provided at home, more older persons with comprehensive needs live at home (National Board of Health and Welfare, 2019). When an older person's needs can no longer be met at home, residential care may be required. The older person's needs are then assessed and a care decision is made by a home help officer. Six months after moving into residential care, $19 \%$ of women and $28 \%$ of men have died, and after two years, $53 \%$ of women and $40 \%$ of men are still residing at the care facility (National Board of Health and Welfare, 2019). It is mainly nursing assistants and registered nurses who provide care in older persons' homes and in residential care. Nursing assistants in home or residential care are the most common profession in Sweden, with 136,400 employed by public and private actors (Statistics Sweden, 2019). Apart from personal care, healthcare including medication is provided. Registered nurses are responsible for the nursing and medical care, while first-line managers are responsible for administration, economy and staff management. Other professions involved in municipal care are occupational and physical therapists, while physicians usually belong to another organization under the responsibility of the county council. In Sweden, there is no widespread tradition of involving volunteers in the care of older people. One reason for this is that there is the idea that this is the responsibility of society and that older people should not be dependent on charity.

\section{Data collection and participants}

Simple random sampling (Dillman, Smyth, \& Christian, 2014; Polit \& Beck, 2012) was used in which units were identified from the National Board of Health and Welfare's (2018) website. Every eighth unit was randomly selected from a compilation of 4058 home- and residential-care units in Sweden, for a total of 504 selected units. The e-mail address of each unit's manager was then searched for via the municipality's website or contact centre. An e- 
mail message was sent to the first-line managers of the 504 units; 467 managers received the message and were considered eligible participants. The e-mail message included a link to the online questionnaire and, as short introductions to the study, links to a two-minute introductory film and an information letter. The letter (i) presented the purpose of the study, (ii) stated that participation was voluntary, (iii) described how responses would be handled and stored according to legislation, and (iv) provided the names and contact information of the researchers. Data were collected via a self-administered questionnaire between 15 May and 28 June 2019. Fifty-six participants responded after the first e-mail message; three reminder messages were then sent, leading to 81 more responses. The inclusion criteria were being a first-line manager in municipal care and service to older people and being responsible for staff. In total, 136 participants were included in the study, after one participant was excluded for not being responsible for staff; the response rate was $29 \%$.

The Evasys web-based survey tool was used to design and distribute the questionnaire and later to store and protect the data. When the survey was closed, the collected data were automatically transferred to Excel and SPSS. Kristianstad University has overall responsibility for the data and follows the guidelines of GDPR, the European Union's General Data Protection Regulation (The Swedish Data Protection Authority, n.d.).

\section{Questionnaire}

The questionnaire development was inspired by earlier results of the LONE study. The questionnaire consisted of demographic questions about the unit and the first-line manager, as well as questions about the manager's views of staff and volunteers. The questionnaire was structured according to five themes: the unit, existential loneliness and existential issues, staff, volunteers, and the manager him/herself. The questionnaire included statements to be responded to using an adjectival response scale with continuous responses as well as questions with fixed-response alternatives or response alternatives such as 'Yes', 'No', and 'I don't know'. Some of the questions had multiple-choice response alternatives combined with the possibility for the managers to add other alternatives than those already specified. There were also open-ended questions allowing respondents to give deeper descriptions in their own words, with no word limits. The response alternatives for one question were reversed due to a technical error, so responses to this question were not included in the results. 


\section{Analysis}

Descriptive statistics have been used to present demographics and the data collected. The answers to the open-ended questions have been compiled, discussed between the authors, and presented in descriptive form; in addition, illustrative excerpts are quoted from the responses.

\section{Ethical aspects}

This study is part of the LONE study, which was approved by the Ethical Review Board, Lund (ref. nos. 2014/652 and 2018/715); however, as this study did not fall within the scope of the Ethics Review Act (2003:460), no separate ethics approval application was made. The guidelines of the Helsinki Declaration were followed (World Medical Association, 2013. A link to the online survey was sent in an e-mail message, which also included information that participation was voluntary. By completing the questionnaire, the participants gave their consent. No questions about the managers' own health or about other sensitive matters were asked in the questionnaire, nor was there any pressure to participate in the study. The researchers could not identify who did or did not participate, and prospective participants were informed of this in advance.

\section{RESULTS}

The responding managers $(n=136)$ had a mean age of 51 years and were $83 \%$ women. Most respondents had an educational background in social work $(40 \%)$ or as registered nurses (24\%) and 67\% had over five years' experience as managers. Of the respondents, $53 \%$ were responsible for 31-50 employees and 9\% were responsible for over 70 employees (Table 1). Almost all the respondents (98\%) were responsible for nursing assistants (NAs), but some were also responsible for registered nurses (15\%), occupational therapists $(10 \%)$, and physiotherapists (8\%); $15 \%$ of the managers were also responsible for service staff. Most of the care units were in the public sector $(82 \%)$, whereas $17 \%$ were in the private sector and one unit was organized by a non-profit foundation. Nearly half of the managers (44\%) reported that their units used volunteers (Table 1). The Friend-Visitor Service (a self-organized volunteer organization) and the Swedish Church were the main groups organizing volunteers, supplying $55 \%$ and $53 \%$ of the volunteers, respectively, followed by municipal volunteer organizations and the Red Cross, supplying $25 \%$ and $23 \%$ of volunteers, respectively. The 
answers to open-ended questions also mentioned several other volunteer organizations, such as local organizations and reading circles.

Table 1. Descriptions of first-line managers, units, and volunteer engagement, $n=136$

\section{Characteristics}

Age $^{1}$

Range, mean (SD)

$27-74 \quad 51(9.5)$

\section{Gender $^{2}$}

Women

n (\%)

Men

$111 \quad(83)$

Other

\section{Education $^{3}$}

Social work

Registered Nurse

Occupational therapist

Physiotherapist

Other reported education (e.g., management, behavioural science, and social

science)

Work experience as a manager in health and social care ${ }^{2}$

$$
\begin{aligned}
& <1 \text { year } \\
& 1-5 \text { years } \\
& 6-10 \text { years } \\
& >10 \text { years }
\end{aligned}
$$

\section{Work experience as a manager in the current setting}

$$
\begin{aligned}
&<1 \text { year } \\
& 1-5 \text { years } \\
& 6-10 \text { years } \\
&>10 \text { years }
\end{aligned}
$$

\section{Care setting ${ }^{3}$}

Home care

Senior housing

Group dwelling

Residential care

\section{Number of employees}

$$
\begin{aligned}
& 1-10 \\
& 11-30 \\
& 31-50 \\
& 51-70 \\
& >70
\end{aligned}
$$

Volunteer engagement at the unit ${ }^{4}$

Yes

No 


\section{First-line managers' views of older persons' existential issues and existential conversations}

Of the first-line managers, $11 \%$ reported that older people in their care units frequently and $77 \%$ that they sometimes expressed existential loneliness. Sixty-two per cent of managers reported that staff often and 32\% that staff sometimes had opportunities for individual conversations with care recipients. Furthermore, $13 \%$ of managers stated that their staff often and $68 \%$ that staff sometimes had conversations about existential issues with the older persons in their care (Table 2).

Table 2. First-line managers' views of older persons' existential needs and existential conversations, $n=136$

Older persons express existential loneliness

Frequently

Sometimes

Rarely

Never

$-$

Don't know

Staff have conversations about existential issues with older persons

Frequently

Sometimes

Rarely

Never

Don't know

Staff have conversations about existential issues among colleagues ${ }^{1}$

Frequently

Sometimes

Rarely

Never

Don't know

\footnotetext{
${ }^{1}$ Missing $=1$
}

In the answers to open-ended questions, the respondents said that such 'existential' conversations treated life as well as death and dying and were about the older person's present life situation, past and uncertainty about the future, and approaching death. The managers said that the conversations between staff and older persons could be about fear, loneliness, loss, grief, sense of alienation, and being limited by a frail body. They also described older persons who no longer found life meaningful and missed being useful to others, as well as those who 
were satisfied and ready to die. According to one manager, in such existential conversations, older persons might say that "They feel content and "finished" with life. They describe how they miss having close relationships or relatives, miss having the feeling of being useful'. Another manager wrote that the older persons spoke of:

The longing for a sense of belonging to someone, the sadness over no longer being able to walk and move around - being imprisoned in one's own body. The enormous silence. Being unable to control one's life - the inexorable approach of death. All [their] friends and spouses have passed away and they are left alone.

Furthermore, $16 \%$ of the first-line managers stated that their staff often and $58 \%$ that staff sometimes had conversations with their colleagues about existential issues (Table 2). In the answers to open-ended question, the managers said that the staff conversations with colleagues could be about the staff themselves, about how they could best support older persons. These conversations also stressed the importance of listening to and confirming the older persons' feelings and existential thoughts, as well as having the courage to remain close and be there for them. Such conversations were also about how to ask sensitive questions and about feeling inadequate and frustrated at having insufficient time for supportive conversations with older persons.

The managers further said that their staff discussed existential questions related to the older persons, possibly concerning difficulties related to ageing such as bodily deterioration and feeling lonely despite having other persons around. The respondents also spoke of staff encounters with and reactions to older persons who were afraid of dying or who wanted to end their lives. One manager described reflective staff conversations regarding older persons' various needs:

How we might help all individuals preserve their health and promote their independence, to avoid creating further loneliness. Talk about life and about getting older, about death. How some of them say they are content and are done with life, and exude calmness, whereas others are extremely uneasy, and have a different need to talk about life and death. 


\section{First-line managers' views of obstacles to existential conversations}

Regarding major obstacles to existential conversations on the part of older persons, $85 \%$ of managers identified impaired cognition (e.g., dementia and stroke) and 51\% identified aphasia as problems. Sixty-six per cent of managers reported that unwillingness and 59\% reported that insecurity on the part of the older persons impeded talk about existential matters. Not speaking the same language as staff was another obstacle to such conversations, with about $15 \%$ of managers reporting that there were older persons in their unit who were limited in conversations due to language barriers.

Regarding major obstacles to existential conversations on the part of staff, insecurity was identified by $88 \%$ of managers, followed by unwillingness/uneasiness, identified by $43 \%$. Language barriers, i.e., staff not speaking the same language as the older person, were also reported to be obstacles to existential conversations (Table 3, Figure 1). Fifty-seven per cent of the managers stated they had staff with limited ability to speak Swedish. Most of them estimated language barriers to affect $1-10 \%$ of staff, but ten managers estimated language barriers to affect $20-40 \%$. Several managers commented that limited ability to speak Swedish was mainly found among temporary workers.

Table 3. First-line managers' views of obstacles to existential conversations, $n=136$

\section{Obstacles among older persons to having conversations about existential} issues $^{1}$ Insecurity

Unwillingness/uneasiness

Language barriers

Obstacles among staff to having conversations about existential issues ${ }^{1}$ 


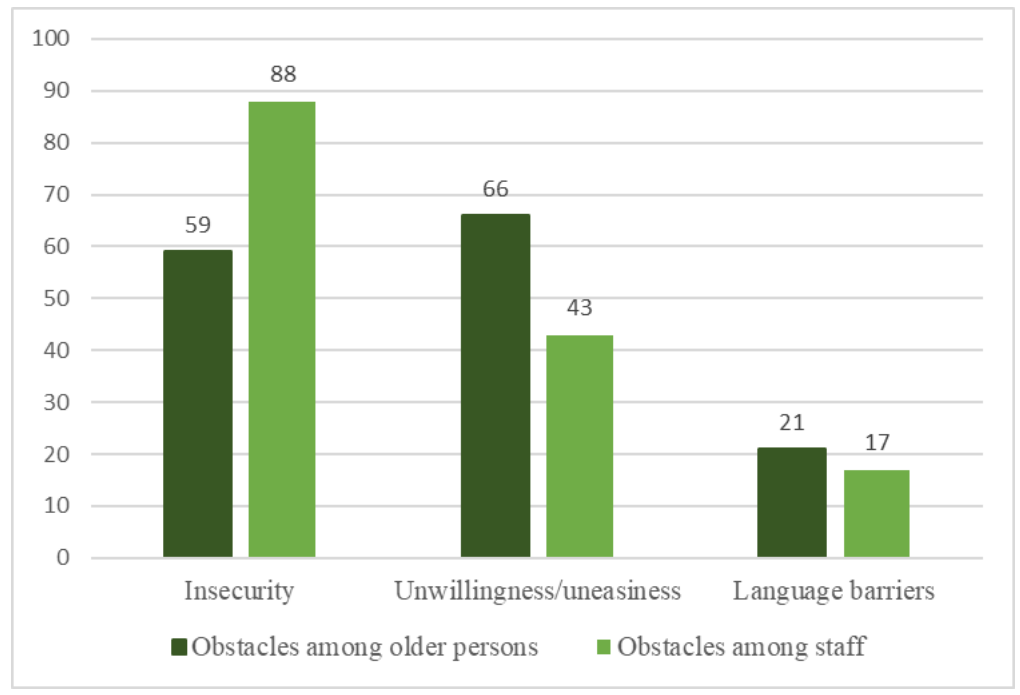

Figure 1. First-line mangers view on obstacles to have conversations about existential issues on the part of older persons and staff $(\%)$.

\section{First-line managers' views of support provided and hindrances to support}

Most of the managers (73\%) stated that their staff received support in encountering existential issues among the older persons they cared for. Of the managers, $65 \%$ said that this support took the form of individual support from the manager, $52 \%$ that it was support from registered nurses, $36 \%$ that it was structured reflection, and $27 \%$ that it was education. Six percent reported that clinical supervision was regularly provided at the unit (Table 4).

Table 4. First-line managers' views of support for staff, $n=136$

Support in encountering existential issues ${ }^{1}$

Yes

No

\section{Form of support provided}

Clinical supervision on a regular basis $\quad 8$ (6)

Structured reflection

Support from the manager

Support from the registered nurse 
In the answers to open-ended questions, one manager cited examples of the support provided: 'A mixed bag - we offer them supervision if needed and individual conversations if they so desire, though not regularly'. Managers also described other forms of support, such as supervision on special occasions when needed, and the possibility of contacting a counsellor or psychologist at the local healthcare centre, the occupational healthcare service, or the Swedish Church.

The managers were also asked to describe what kind of additional support they thought that their staff needed. Their answers to open-ended questions mainly concerned opportunities for reflection and a supportive and open climate in the work group that would help staff be confident and flexible in their daily work, as necessary. The managers also described a need for knowledge of the ageing process and skills in communication methodology; one manager wrote: 'Therapeutic communication techniques: the courage to listen. Adequate knowledge to be able to be professional'.

The managers were asked to describe organizational hindrances to providing support. In the answers to the open-ended questions, they mainly mentioned limited financial resources, limited time, and logistical difficulties. In addition, the managers highlighted their own limited opportunities stemming from the design and scope of their management assignment, collaboration, and the structure of their organization. One manager commented: 'Shortage of resources. Do not have the financial means/time to allow for the scheduling of that. The message from management is that finances take precedence over quality'. Lack of supervisors who could address existential issues was another hindrance. However, others claimed that there were no obstacles, but that it was instead a matter of prioritizing. One manager wrote: 'We are a small organization so there are no obstacles. We might broach the subject in a general way at a staff meeting, and in the context of supervision'.

\section{First-line managers' views of volunteer engagement}

According to the 60 managers whose units used volunteers, the volunteers' engagement ranged from a few days a month (according to $45 \%$ of managers) to every day (according to $2 \%$ ). The volunteers were engaged in everyday conversations (according to $62 \%$ of managers), music/entertainment (according to 57\%), walking/outdoor activity (according to $45 \%$ ), and reading (according to 40\%) (Table 5). Additional activities mentioned by the 
managers were accompanying the older person to the hospital, healthcare centre, or hairdresser, and helping out in the dining room and with baking.

Forty-three percent of the managers reported that the volunteers had conversations about existential issues with the older persons. The frequency of such existential conversations ranged from sometimes (according to $32 \%$ of managers) to frequently (according to $3 \%$ ). Over half of the managers stated that they did not know whether the volunteers had such conversations. Regarding desirable opportunities for volunteers, $83 \%$ of the managers identified everyday conversations and $73 \%$ identified conversations about existential issues (Table 5).

Table 5. First-line managers' views of volunteer engagement, $n=60$

Frequency of volunteer engagement at the unit

Every day

A few days a week

A few days a month

Less than once a month

Activities that volunteers are engaged in ${ }^{1}$

Walking/outdoor activity

Reading

Music/entertainment

Everyday conversations

Conversations about existential issues

\section{Volunteers having conversations about existential issues with older persons}

Frequently

Sometimes

Rarely

Never

Don't know

Desirable activities for volunteers to engage in ${ }^{1}$

Walking/outdoors

Reading

Music/entertainment

\footnotetext{
${ }^{1}$ More than one alternative was possible
} 
Seventy per cent of the managers whose units had volunteers stated that there were no obstacles to engaging volunteers. The managers who stated that there were obstacles to involving volunteers mentioned reasons such as too few volunteers relative to the need, the older persons' poor health, and the volunteers' own competence or insecurity. One manager wrote: 'We have a volunteer centre, but they themselves are uncertain about their role and their ability. Sometimes things get confusing - if we have a lot of people coming into the ward, people who are coming and going'. Another manager mentioned time and that volunteers' activity is voluntary: 'If anything, time is an issue. They take their own initiatives. It's voluntary, so you can't demand anything'.

About one third of the managers whose units used volunteers stated that they were involved in introducing/orienting the volunteers. In the answers to open-ended questions, some of the managers described getting personally involved in this introduction effort, either regularly or when needed, whereas others said that somebody else had the role. One manager wrote:

[We] are sometimes in contact with certain organizations, but it's usually the NAs who have that contact - they have closer relationships with the older people and pick up on their needs and wishes regarding activities. I'm more in the background, providing support for the organization of the activities.

Another manager was more active and wrote: 'When volunteers call us, I jump at the opportunity to establish relationships'.

\section{DISCUSSION}

Although the first-line managers expressed awareness of the importance of satisfying older persons' existential needs in home and residential care, they said that it was difficult to meet these needs. The present results indicate that the managers knew that existential loneliness was often expressed by older persons. They believed that staff usually had opportunities for individual conversations with the older persons, although conversations about existential issues did not always occur. When conversations about existential issues occurred, they were, according to the managers, about life and death, fears, loneliness, alienation, and feeling limited by a frail body. These results are similar to those of a study in nursing homes (Österlind, Ternestedt, Hansebo, \& Hellström, 2017) where older persons expressed feeling existentially trapped in themselves and in their bodies and often felt locked away from the outside world. Managers reported that impaired cognition and aphasia were hindrances to 
having existential conversations, indicating manager's awareness that existential needs are fundamental even among persons who have difficulty expressing their needs, for example, due to dementia. Lundin, Berg, and Hellström Muhli (2013) concluded that existential needs must be highlighted in care for older persons, and emphasized that acknowledging older persons as human beings is fundamental to improving their well-being.

Encountering existential issues of life and death is a major challenge for staff caring for older persons. If support for staff is lacking, there are risks that older persons' existential needs might not be met and that staff might experience dissatisfaction and choose to withdraw when confronted with existential issues. Our study found that staff insecurity was reported by firstline managers to be the most important obstacle to having conversations about existential issues, indicating that managers were aware of staff need for support. However, support to staff was mainly provided at an individual level by managers and registered nurses, whereas regularly scheduled structured reflections and clinical supervision were rare. One reason for this was a lack of financial resources and time. For example, many managers were responsible for a large number of employees. As the support was provided mostly by the managers themselves, given the large number of employees, it is questionable whether staff receive adequate support in meeting the existential needs of older persons. According to a recent study of managers' experiences of ethical problems in municipal elderly care (Jonasson, Sandman, \& Bremer, 2019), access to adequate resources was crucial to providing care that complies with laws and policies. The researchers found that financial control systems were insensitive to the needs of older persons, and that lack of resources made it difficult for managers to follow laws and policies aimed at ensuring good care provision with a holistic view. Schön Persson, Nilsson Lindström, Pettersson, Nilsson, and Blomqvist (2018) found that having enough time and organizing work to allow staff to have time for reflection and the relational dimension of care are important for building close interpersonal relationships with older persons and colleagues, and are also crucial for work-related well-being. Besides staff, volunteers are a human resource that could improve the well-being of older persons and complement staff work. All the activities that volunteers already engaged in were considered positive, and managers wanted more of these activities, including conversations with older persons about existential matters. Succesfully involving volunteers requires support and engagement from the first-line manager and engagement and a person who coordinates the volunteers. 
Staff insecurity about encountering and addressing existential needs and about having existential conversations with older persons must be taken seriously, as staff insecurity and associated unwillingness were the two most reported obstacles. The managers believed, however, that older persons' unwillingness to talk about existential matters was the main obstacle to existential conversations. A systematic literature review by Hallberg (2004) showed that older people need to talk about existential issues, about life and death, but that they may not explicitly express their desire and need to discuss dying and death or their worries about the future. Such needs are often communicated tacitly (Heap, 1995; Sundler et al., 2016), so attentiveness and responsiveness to older persons' needs and emotions are important skills among care staff (Sundler, Hjertberg, Keri, \& Holmström, 2020). First-line managers are therefore challenged to accommodate older persons' needs to talk about existential matters and to support their staff in developing attentiveness and responsiveness to these needs.

\section{Methodological considerations}

There is no national register of existing home-care providers and residential-care homes in Sweden (National Board of Health and Welfare, 2019), impeding the collection of data that would give an overview at the national level. In addition, no existing instruments cover existential needs among older persons along with associated support for staff and volunteer engagement. To address this lack, we decided to compose a suitable questionnaire with valid questions and response alternatives. The questionnaire was tested during a seminar with researchers and $\mathrm{PhD}$-students. After revisions, it was tested by a person with previous experience as a first-line manager using the read-out-loud method (Wenemark, 2017). As a final test, the researchers in the LONE study completed the questionnaire online, and their comments were used in making further improvements. There is a risk that the respondents may interpret the concept of existential loneliness differently from one another. To reduce this risk, a question regarding managers' perceptions of existential loneliness was initially posed as an opening question in an attempt to give the managers the same starting point. The introductory film had the same intention, and included information on the LONE study's previous results. The questionnaire was designed to include options to respond freely to openended questions, so respondents could provide deeper descriptions in their own words. Many used this opportunity, particularly in connection with the questions about topics of conversation concerning existential issues. The answers to these open-ended questions can 
also be seen as validating the questions, deepening our understanding, and enriching the results.

Although the low response rate threatened the external validity of the study (Polit \& Beck, 2012), probability sampling was used and the units were randomly selected to allow the results to be generalizable to the target population (Dillman et al., 2014). The high response rate on the open-ended questions indicates that the managers who responded were probably those who were engaged in and aware of older persons' existential needs and issues. If so, the problem of not recognizing the existential needs of older people might have been underestimated. Another reason for the low response rate could be first-line managers' high workload in general.

\section{CONCLUSION AND IMPLICATIONS FOR PRACTICE}

Older persons' existential needs merit attention and emphasis, particularly in home and residential care. Staff's insecurity about encountering existential needs and having existential conversations must be taken seriously. Support for staff to increase their confidence, needs to be provided on a regular basis as an integral part of work. First-line managers are challenged to accommodate older persons' existential need, but themselves lack goals and guidelines. Further, lack of time and economical resources are hinders to provide support together with limitations in the management assignment. In times of limited resources, new solutions are needed. Volunteers are a human resource that could improve the well-being of older persons and complement staff work. For a volunteer commitment to be successful and be a contribution in the long term, both support and engagement from the manager and staff at the unit are required.

\section{ACKNOWLEDGEMENTS}

We are most grateful to all first line managers for taking time to answer the questionnaire, and to the LONE research group and the reference group for their valuable input. This study was funded by the Research Platform for Collaboration for Health at Kristianstad University, and the Vardal Foundation and conducted in association with the Swedish National Graduate School for Competitive Science on Ageing and Health (SWEAH), funded by the Swedish Research Council. 


\section{REFERENCES}

Abley, C., Bond, J., \& Robinson, L. (2011). Improving interprofessional practice for vulnerable older people: gaining a better understanding of vulnerability. Journal of Interprofessional Care, 25(5), 359-365.

Andersson, Hallberg, I. R., \& Edberg, A. K. (2008). Old people receiving municipal care, their experiences of what constitutes a good life in the last phase of life. International Journal of Nursing Studies, 45(6), 818.

Andersson, \& Öhlén, J. (2005). Being a hospice volunteer. Palliative Medicine, 19(8), 602609.

Baltes, P. B., \& Smith, J. (2003). New frontiers in the future of aging: from successful aging of the young old to the dilemmas of the fourth age. Gerontology, 49(2), 123-135.

Beck, I., Törnquist, A., Broström, L., \& Edberg, A. K. (2012). Having to focus on doing rather than being-nurse assistants' experience of palliative care in municipal residential care settings. International Journal of Nursing Studies, 49, 455-464.

Connell, B., Warner, G., \& Weeks, L. E. (2017). The Feasibility of Creating Partnerships Between Palliative Care Volunteers and Healthcare Providers to Support Rural Frail Older Adults and Their Families: An Integrative Review. American Journal of Hospice \& Palliative Medicine, 34(8), 786-794.

Dillman, D. A., Smyth, J. D., \& Christian, L. M. (2014). Internet, phone, mail, and mixedmode surveys: the tailored design method. Hoboken, New Jersey: Wiley.

Dodd, S., Hill, M., Ockenden, N., Algorta, G. P., Payne, S., Preston, N., \& Walshe, C. (2018). 'Being with' or 'doing for'? How the role of an end-of-life volunteer befriender can impact patient wellbeing: interviews from a multiple qualitative case study (ELSA). Supportive Care in Cancer, 26(9), 3163-3172.

Ebrahimi, Z., Wilhelmson, K., Eklund, K., Moore, C. D., \& Jakobsson, A. (2013). Health despite frailty: Exploring influences on frail older adults' experiences of health. Geriatric Nursing, 34(4), 289-294.

Edberg, A. K., \& Bolmsjö, I. (2019). Study protocol: Exploring existential loneliness among frail older people. The development phase of the LONE study. JMIR Research Protocols, 8(8), e13607.

Ethics Review Act. 2003:460. Swedish Ethical Review Authority.

Hallberg, I. R. (2004). Death and dying from old people's point of view. A literature review. Aging Clinical and Experimental Research, 16(2), 87-103.

Health and Medical Service Act. 2017:30. Ministry of Health and Social Affairs, Stockholm. 
Heap, K. (1995). Samtal med äldre: om kommunikation, minnen, kriser och sorg [In English: Conversations with older people: about communication, memories, crises and grief]. Stockholm: Liber utbildning.

Hill, H., Evans, J. M., \& Forbat, L. (2015). Nurses respond to patients' psychosocial needs by dealing, ducking, diverting and deferring: an observational study of a hospice ward. BMC Nursing, 14, 60.

Holmberg, B., Hellström, I., \& Österlind, J. (2018). End-of-life care in a nursing home: Assistant nurses' perspectives. Nursing Ethics, 969733018779199.

Jonasson, L. L., Sandman, L., \& Bremer, A. (2019). Managers' experiences of ethical problems in municipal elderly care: a qualitative study of written reflections as part of leadership training. Journal of healthcare leadership, 11, 63.

Lundin, A., Berg, L.-E., \& Hellström Muhli, U. (2013). Feeling existentially touched - A phenomenological notion of the well-being of elderly living in special housing accommodation from the perspective of care professionals. International Journal of Qualitative Studies on Health and Well-being, 8(1), 1-8.

National Board of Health and Welfare. (2018). Survey on Elderly Care and Municipal Health Care. Retrieved 19-03-19 and 20-01-01 from https://www.socialstyrelsen.se/statistikoch-data/oppna-jamforelser/socialtjanst/aldreomsorg/hemtjanst-och-sarskilt-boende/

National Board of Health and Welfare. (2019). Care of older people. Progress report 2019. Retrieved 20-01-01 from https://www.socialstyrelsen.se/stod-i-arbetet/aldre/

Norell Pejner, M., Ziegert, K., \& Kihlgren, A. (2012). Trying to cope with everyday life-emotional support in municipal elderly care setting. International Journal of Qualitative Studies on Health and Well-being, 7, 1-7.

Polit, D. F., \& Beck, C. T. (2012). Nursing Research: Generating and Assessing Evidence for Nursing Practice, $9^{\text {th }}$ ed. Philadelphia: Wolters Kluwer.

Sand, L., \& Strang, P. (2006). Existential loneliness in a palliative home care setting. Journal of Palliative Medicine, 9(6), 1376-1387.

Santamäki Fischer, R., Norberg, A., \& Lundman, B. (2008). Embracing opposites: meanings of growing old as narrated by people aged 85. The International Journal of Aging \& Human Development, 67(3), 259.

Schön Persson, S., Nilsson Lindström, P., Pettersson, P., Nilsson, M., \& Blomqvist, K. (2018). Resources for work-related well-being: A qualitative study about healthcare employees' experiences of relationships at work. Journal of Clinical Nursing, 27(2324), 4302-4310. 
Shaw, R. L., West, K., Hagger, B., \& Holland, C. A. (2016). Living well to the end: A phenomenological analysis of life in extra care housing. International Journal of Qualitative Studies on Health and Well-being, 11, 31100.

Sjöberg, M., Beck, I., Rasmussen, B. H., \& Edberg, A. K. (2018). Being disconnected from life: meanings of existential loneliness as narrated by frail older people. Aging \& Mental Health, 22(10), 1357-1364.

Sjöberg, M., Edberg, A. K., Rasmussen, B. H., \& Beck, I. (2019). Being acknowledged by others and bracketing negative thoughts and feelings: Frail older people's narrations of how existential loneliness is eased. International Journal of Older People Nursing, 14(1), e12213.

Social and Service Act. 2001:453. Ministry of Health and Social Affairs, Stockholm.

Statistics Sweden. (2019). Professions in Sweden. Retrieved 20-01-01 from https://www.scb.se/hitta-statistik/sverige-i-siffror/utbildning-jobb-och-pengar/yrken-isverige/

Sundler, A. J., Eide, H., van Dulmen, S., \& Holmström, I. K. (2016). Communicative challenges in the home care of older persons - a qualitative exploration. Journal of Advanced Nursing, 72, 2435-2444.

Sundler, A. J., Hjertberg, F., Keri, H., \& Holmström, I. K. (2020). Attributes of personcentred communication: A qualitative exploration of communication with older persons in home health care. International Journal of Older People Nursing, 15(1), e12284.

Sundström, M., Blomqvist, K., \& Edberg, A. K. (submitted). Being a volunteer encountering older people's loneliness and existential loneliness: Alleviating loneliness for others and oneself. Submitted for publication.

Sundström, M., Blomqvist, K., Edberg, A. K., \& Rämgård, M. (2019). The context of care matters: Older people's existential loneliness from the perspective of health care professionals. A multiple case study. International Journal of Older People Nursing, 14, e12234.

Sundström, M., Edberg, A. K., Rämgård, M., \& Blomqvist, K. (2018). Encountering existential loneliness among older people: perspectives of health care professionals. International Journal of Qualitative Studies on Health and Well-being, 13, 1474673.

Svanström, R., Johansson Sundler, A., Berglund, M., \& Westin, L. (2013). Suffering caused by care-elderly patients' experiences in community care. International Journal of Qualitative Studies on Health and Well-being, 20(8), 20603. 
The Swedish Data Protection Authority (n.d.) Retrieved 20-01-01 from https:/www.datainspektionen.se/other-lang/in-english/the-general-data-protectionregulation-gdpr/

Wijesiri, H. S. M. S. K., Samarasinghe, K., Edberg, A. K. (2019). Loneliness among older people living in care homes in Sri Lanka. International Journal of Older People Nursing, 14(4), e12253.

Wenemark, M. (2017). Enkätmetodik med respondenten i fokus [In English: Survey methodology with the respondent in focus]. Lund: Studentlitteratur.

Wolf, A., Ekman, I., \& Dellenborg, L. (2012). Everyday practices at the medical ward: a 16month ethnographic field study. BMC Health Services Research, 12, 184.

World Medical Association. (2013) Declaration of Helsinki: ethical principles for medical research involving human subjects. Retrieved 20-01-01 from https://www.wma.net/policies-post/wma-declaration-of-helsinki-ethical-principles-formedical-research-involving-human-subjects/

Österlind, J., Ternestedt, B. M., Hansebo, G., \& Hellström, I. (2017). Feeling lonely in an unfamiliar place: older people's experiences of life close to death in a nursing home. International Journal of Older People Nursing, 12(1). doi:10.1111/opn.12129 



\section{Malmö University Health and Society Doctoral Dissertations}

Ross, M. W. Typing, doing and being. A study of men who have sex with men and sexuality on the Internet. 2006:1

Stoltz, P. Searching for meaning of support in nursing. A study on support in family care of frail aged persons with examples from palliative care at home. 2006:2

Gudmundsson, P. Detection of myocardial ischemia using real-time myocardial contrasts echocardiograpy. 2006:3

Holmberg, L. Communication in palliative home care, grief and bereavement. A mother's experiences. 2007:1

Ny, P. Swedish maternal health care in a multiethnic society - including the fathers. 2007:2

Schölin, T. Etnisk mångfald som organisationsidé. Chefs- och personalpraktiker i äldreomsorgen. 2008:1

Svensson, O. Interactions of mucins with biopolymers and drug delivery particles. 2008:2

Holst, M. Self-care behaviour and daily life experiences in patients with chronic heart failure. 2008:3

Bahtsevani, C. In search of evidence-based practices. Exploring factors influencing evidence based practice and implementation of clinical practice guidelines. 2008:4

Andersson, L. Endocytosis by human dendritic cells. 2009:1

Svendsen, I. E. In vitro and in vivo studies of salivary films at solid/liquid interfaces. 2009:2

Persson, K. Oral health in an outpatient psychiatric population. Oral status, life satisfaction and support. 2009:3

Hellman, P. Human dendritic cells. A study of early events during pathogen recognition and antigen endocytosis. 2009:4

Baghir-Zada, R. Illegal aliens and health (care) wants. The cases of Sweden and the Netherlands. 2009:5

Stjernswärd, S. Designing online support for families living with depression. 2009:6

Carlsson, A. Child injuries at home - prevention, precautions and intervention with focus on scalds. 2010:1

Carlson, E. Sjuksköterskan som handledare. Innehåll i och förutsättningar för sjuksköterskors handledande funktion i verksamhetsförlagd utbildning - en etnografisk studie. 2010:2

Sinkiewicz, G. Lactobacillus reuteri in health and disease. 2010:3

Tuvesson, H. Psychiatric nursing staff and the workplace. Perceptions of the ward atmosphere, psychosocial work environment, and stress. 2011:1

Ingvarsdotter, K. Mental ill health and diversity. Researching human suffering and resilience in a multicultural context. 2011:2 
Hamit-Eminovski, J. Interactions of biopolymers and metal complexes at biological interfaces. 2011:3

Mellgren, C. What's neighbourhood got to do with it? The influence of neighbourhood context on crime and reactions to crime. 2011:4

Annersten Gershater, M. Prevention of foot ulcers in patients with diabetes mellitus. Nursing in outpatient settings. 2011:5

Pooremamali P. Culture, occupation and occupational therapy in a mental care context- the challenge of meeting the needs of Middle Eastern immigrants. 2012:1

Gustafsson A. Aspects on sepsis: treatment and markers. 2012:2

Lavant, E. Multiplex HLA-DR-DQ genotyping. For genetic epidemiology and clinical risk assessment. 2012:3

Wangel, A-M. Mental ill-health in childbearing women. Markers and risk factors. 2012:4

Scaramuzzino, R. Equal opportunities? - A cross-national comparison of immigrant organisations in Sweden and Italy. 2012:5

Ivert, A-K. Adolescent mental health and utilisation of psychiatric care - The role of parental country of birth and neighbourhood of residence 2013:1

Znamenskaya, Y. Effect of hydration on thermodynamic, rheological and structural properties of mucin. 2013:2

Andersson, F. The female offender. Patterning of antisocial and criminal activity over the lifecourse. 2013:3

Lindroth, M. Utsatthet och sexuell hälsa - en studie om unga på statliga ungdomshem. 2013:4

Hulusjö, A. The multiplicities of prostitution experience - narratives about power and resistance. 2013:5

Falk, M. Direct electron transfer based biofuel cells. Operation in vitro and in vivo. 2014:1

Finnbogadóttir, H. Exposure to domestic violence during pregnancy. Impact on outcome, midwives' awareness, women's experience and prevalence in the south of Sweden. 2014:2

Fagerström, A. Effects of surfactant adjuvants on barrier properties of plant leaf cuticle. 2014:3

Lamberg, P. Design and characterization of direct electron transfer based biofuel cells including tests in cell cultures. 2014:4

Richert, T. Överdoser, försörjningsstrategier och riskhantering - livsvillkor för personer som injicerar narkotika. 2014:5

Örmon, K. Experiences of abuse during the life course. - Disclosure and the care provided among women in a general psychiatric context. 2014:6

Sjöblom, I. Planerade hemförlossningar i Norden - kvinnors och barnmorskors perspektiv. 2014:7

Albèr, C. Humectants and Skin - Effects of hydration from molecule to man. 2015:1 
Kisch M., A. Allogeneic stem cell transplantation. - Patients' and sibling donors' perspectives. 2015:2

Weiber, I. Children in families where the mother has an intellectual or developmental disability - incidence, support and first person perspectives. 2015:3

Schlyter, M. Myocardial infarction, Personality factors, Coping strategies, Depression and Secondary prevention 2016:1

Carlström, C. BDSM - Paradoxernas praktiker. 2016:2

El-Schich, Z. Novel imaging technology and tools for biomarker detection in cancer. 2016:3

Boonsatean, W. Living with type 2 diabetes in Thai population: Experiences and socioeconomic characteristics. 2016:4

Vejzovic, V. Going through a colonoscopy and living with inflammatory bowel disease: Children's and parents' experiences and evaluation of the bowel cleansing quality prior to colonoscopy. 2016:5

Isma, G.E. Overweight and obesity in young children: Preventive work in child health care with focus on nurses' perceptions and parental risk factors. 2016:6

Brännvall, M. Frigörelse med förhinder - Om polisanmälan när kvinnor tar sig ur mäns våld i nära relationer. 2016:7

Pankratov, D. Self-charging biosupercapacitors. 2016:8

Guidi, P. Social work assessment of families with children at risk: Similarities and differences in Italian and Swedish public social services. 2016:9

Jakobsson, J. The process of recovery after colorectal cancer surgery: Patients' experiences and factors of influence. 2017:1

Gerell, M. Neighborhoods without community. Collective efficacy and crime in Malmö, Sweden. 2017:2

Wierzbicka, C. New fractionation tools targeting elusive post-translational modifications. 2017:3

Afzelius, M. Families with parental mental illness: Supporting children in psychiatric and social services. 2017:4

Nordgren, J. Making drugs ethnic - Khat and minority drug use in Sweden. 2017:5

Nilsson, E-L. Parental socialization and adolescent offending. 2017:6

Sixtensson, J. Härifrån till framtiden. Om gränslinjer, aktörskap och motstånd i tjejers vardagsliv. 2018:1

Vasiljevic, Z. Ambulatory risk assessment and intervention in the prison services. Using Interactive Voice Response to assess and intervene on acute dynamic risk among prisoners on parole. 2018:2

González Arribas, E. Flexible and transparent biological electric power sources based on nano-structured electrodes. 2018:3 
Svalin, K. Risk assessment of intimate partner violence in a police setting. Reliability and predictive accuracy. 2018:4

Andersson, M. Hate crime victimization: consequences and interpretations. 2018:5

Djampour, P. Borders crossing bodies. The stories of eight youth with experience of migrating 2018:6

Yeung, S.Y. Stimuli-responsive lipid bilayer mimics for protein, virus and cell recognition. 2018:7

Holst-Hansson, A. On a journey for survival: everyday life during radiation therapy from the perspectives of women with breast cancer and their families. 2018:8

Berlin Hallrup, L. Experiences of Everydaylife and Participation for People with Intellectual Disabilities -From four Perspectives. 2019:1

Aleksejeva, O. Blue copper proteins as bioelements for bioelectronics devices 2019:2

Wendel, L. Dokumentation, profession och hälso- och sjukvård. Rättsliga perspektiv. 2019:3

Larsson, H. Existentiell ensamhet hos sköra äldre personer: ett närståendeperspektiv. 2020:1

Sundström, M. Existentiell ensamhet hos sköra äldre personer: Vårdpersonals och volontärers erfarenheter och behov av stöd. 2020:2.

The publications are available on-line. https://mau.diva-portal.org/ 

